UNIVERSIDADE DE SÃO PAULO

FACULDADE DE FILOSOFIA, LETRAS E CIÊNCIAS HUMANAS

DANILO AMORIM DE SOUZA

Geografia e individuação

SÃO PAULO

2014 
DANILO AMORIM DE SOUZA

\title{
Geografia e individuação
}

\author{
Dissertação apresentada ao \\ Departamento de Geografia como \\ requisito para obtenção do título de \\ mestre. \\ Área de concentração em Geografia \\ Humana.
}

Orientador: Prof. Dr. Elvio Rodrigues Martins

\section{SÃO PAULO}


Autorizo a reprodução e divulgação total ou parcial desse trabalho, por qualquer meio convencional ou eletrônico, para fins de estudo e pesquisa, desde que citada a fonte. 
Nome: SOUZA, D. A. Geografia e individuação. Dissertação apresentada ao Departamento de Geografia da Universidade de São Paulo para obtenção do título de Mestre em Geografia Humana.

Aprovado em:

Banca examinadora

Prof. (a). Dr. (a.) Instituição

Julgamento Assinatura

Prof. (a). Dr. (a.) Instituição

Julgamento Assinatura

Prof. (a). Dr. (a.) Instituição

Julgamento Assinatura 
À Amélia, exemplo de coragem, generosidade e simplicidade, que não pôde ver este resultado final

À Shirley, por me permitir conhecer o sentido mais verdadeiro do amor, como a carência vital. Eu sem ti, "coisa incompreensível" 


\section{AGRADECIMENTOS}

Ao prof. Dr. Elvio Rodrigues Martins, pela sensibilidade na condução da orientação dessa pesquisa e na compreensão de suas idas e vindas, ditadas, dentre outras, pelas dificuldades, de sempre e próprias aos tempos atuais, em conciliar compromisso social e rigor intelectual. Ao Elvio, ainda, pelo rico diálogo que, por vezes, superou a relação formal da orientação. No sincero desejo de que ele continue...

À prof. ${ }^{a}$ Dr. ${ }^{a}$ Lívia Cotrim, pelos ensinamentos desde a graduação e pelo exemplo de lucidez em tempos tão desfavoráveis. Também, pelos comentários e indicações, na banca da qualificação e em todo o processo desta pesquisa.

À prof. a Dr. a Amélia Luisa Damiani, pelos comentários e indicações na banca de qualificação, cuja assertividade e rigorosidade permitiram reorientar ou completar pontos essenciais da argumentação.

Aos amigos de sempre, que as diferentes distâncias (geográficas ou do cotidiano) não conseguem nos afastar. Os encontros são sempre fundamentais, simplesmente, para a vida. Beto e Tati. Rodrigo e Aline. Diogo e Talita. Felipe. Muito obrigado! Ao Beto e ao Rodrigo, também, pelas leituras e comentários de trechos do texto.

Ao Ronaldo (você sim vítima dos meus textos) pelas leituras, comentários e, acima de tudo, pelo companheirismo de um irmão mais velho. A você, também, muito obrigado! E à Tânia, cujas distâncias, agora invertidas, não impedem o afeto.

Aos companheiros de luta, forjados na Unicastelo. Que as distâncias, principalmente as geográficas, não gerem o afastamento. Em especial ao Clécio e ao Zilmar. Abraços saudosos!

Aos meus pais, José e Hilda, ao Daniel e à Cinthia, por compreenderem a permanente ausência. À Manu e ao Gabriel (rebento vindouro!) por tão logo já padecerem da ausência do tio. Amo vocês!

À nova família, que tão bem me acolheu e já suportou (sei que é duro) as ausências causadas pelo trabalho. "Seu” Daniel e Amélia (in memorian), Maurício e Karina, Lucio e Dani, Matheus e João. Um fraterno abraço! E sorte nos novos caminhos, juntos! 
Ao antigo grupo de leituras, no interior do qual os passos iniciais desta pesquisa se engendraram. Carlos, Frida, Renata, Tadeu e Rodolfo. Por futuros encontros!

Ao CNPq e, portanto, aos trabalhadores brasileiros que financiaram os anos finais deste trabalho.

Mais uma vez, e sempre, agradeço à amada e companheira, por todo seu carinho, dedicação e compreensão, que permitiu, pela leitura de algumas partes, não apenas que esse trabalho tivesse mais coerência e sentido, mas, pela entrega inteira e total, que a minha vida seja mais coerente e repleta de sentidos. Shirley, além de uma experiência enriquecedora, nascer de novo, com você, tem me permitido compreender mais concretamente o significado de humanização e, portanto, me faz crer, ainda, que o mundo possa ser um lugar melhor e mais digno para toda a humanidade. Eu amo você! 
"Sem espírito ou dimensão ontológica, ou seja, sem o estatuto de uma filosofia primeira, é impossível sequer perceber quais são, num dado momento, os problemas científicos verdadeiros - o que deve ser estudado, qual a hierarquia dos mesmos e suas posições no quadro hierárquico das urgências sociais" José Chasin, Ad Hominem - Rota e prospectiva de um projeto marxista 


\section{RESUMO}

SOUZA, D. A. Geografia e individuação. 2014. Dissertação (mestrado) - Faculdade de Filosofia, Letras e Ciências Humanas, Departamento de Geografia, Universidade de São Paulo, São Paulo, 2014.

A presente dissertação resulta de uma pesquisa de caráter exploratório e objetiva contribuir para a apropriação, no âmbito da ciência geográfica, dos recentes esforços de resgate da dimensão ontológica da obra de K. Marx (1818-1883), destacando a compreensão radical e crítica do processo de individuação, que vai à raiz, buscando sua gênese e necessidade social. Explora, assim, as obras em que Marx, buscando sua autocompreensão, institui um pensamento próprio e os fundamentos de um estatuto ontológico. Desse modo, associa-se ao movimento de crítica da tradição geográfica, que se caracteriza especialmente pela apropriação do pensamento marxista, e com ele buscou estabelecer, permanentemente, pontos de intersecção, diálogos e críticas, bem como com as próprias matrizes clássicas da ciência geográfica - ressaltando a apreensão da hegemonia, e suas consequências, do viés epistemológico no movimento de renovação crítica da disciplina e a problematização da categoria de complexo geográfico, associando-a à noção do ser social como um complexo de complexos. Por fim, explora categorias concernentes à geografia do processo de individuação em sua historicidade e contraditoriedade, identificando as relações entre os diferentes complexos geográficos (rurais e urbanos) e suas configurações territoriais (em especial a relação entre campo e cidade) com os distintos tipos de individualidade humano-social emergentes nesse processo. Evidencia, de um lado, a conexão entre as sociabilidades em que predominam o meio natural e complexos geográficos rurais com uma individualidade que tem como meta e limite a reprodução dos pressupostos dados. De outro, discute a relação da individualidade moderna com o meio geográfico urbano e mundial que com ela se configura, sob o signo da exterioridade e oposição. Aponta e problematiza, ainda, os fundamentos ontológicos da concepção de homem presente na obra de F. Ratzel (18441904), tomado como representante das matrizes clássicas da ciência geográfica e expressão fenomênica da individualidade moderna, na medida em que representa os indivíduos cindidos em relação ao gênero humano e, por conseguinte, ao meio geográfico.

Palavras-chave: geografia, ontologia, Karl Marx, complexo geográfico, individuação, urbano 


\begin{abstract}
SOUZA , D. A. Geography and individuation. 2014. Dissertação (mestrado) Faculdade de Filosofia, Letras e Ciências Humanas, Departamento de Geografia, Universidade de São Paulo, São Paulo, 2014.
\end{abstract}

This dissertation aims to contribute to the appropriation, within the realm of contemporary geography, of the recent efforts to rescue the ontological character of Marx's work, highlighting the radical and critical understanding of the individuation process, which goes to the roots, seeking its genesis and social need. It explores, especially, the works in which Marx, seeking his self-understanding, established his own thought and the foundations of an ontological statute. It is associated thus to the critical movement of the geographical tradition, which is characterized especially by the appropriation of Marxist thought, and with this movement it sought permanently to establish points of intersection, dialogue and criticism, as well as with the classical matrices of geographical science. Highlighting the hegemony of the epistemological bias in the movement of the discipline's critical renewal, and its consequences, and the discussion of the geographical complex category, associating it to the notion of social being as a complex of complexes. Finally, explores categories concerning to the geography of the individuation, in its historicity and contradictoriness process, identifying relationships between different geographical complexes (rural and urban) and their territorial settings (especially the relationship between country and city) with different types of emerging human-social individuality in the process. Shows on the one hand, the connection between the sociability that predominate the natural environment and rural geographic complexes with an individuality that aims and limit the reproduction of assumptions. Another discusses the relationship of modern individuality with urban and global geographical environment with which it is set, under the sign of externality and opposition. Points and discussing the ontological foundations of the man's conception in F. Ratzel's (1844-1904) work, taken as representative of the classical matrices of geographical science and phenomenal expression of modern individuality.

Keywords: geography, ontology, Karl Marx, geographic complex, individuation, urban 


\section{SUMÁRIO}

APRESENTAÇÃO 12

CAPÍTULO 1 - CARACTERIZAÇÃO DA QUESTÃO: INDIVÍDUO E MARXISMO NA CRÍTICA DA GEOGRAFIA 23

$\begin{array}{ll}\text { 1.1. A crise da geografia... } & 23\end{array}$

1.2. e a sua crítica político-ideológica: o viés epistemológico 39

1.2.1. Considerações sobre as "escolas nacionais"

1.3. Lineamentos de uma crítica ontológica

1.4. Limites e críticas ao movimento de renovação 63

CAPÍTULO 2 - CRÍTICA FILOSÓFICA E ESTATUTO ONTOLÓGICO: A CONSTITUIÇÃO DO PENSAMENTO MARXIANO $\mathbf{7 6}$

2.1. Da crítica da religião à crítica da filosofia especulativa: a posição ontológica marxiana 80

2.1.1. A prioridade da objetividade $\quad 85$

2.2. A crítica da política: socialidade e determinação ontonegativa da politicidade 98

2.3. A crítica da economia política: a analítica da totalidade e a atividade sensível $\quad 119$

CAPÍTULO 3 - GEOGRAFIA, COMPLEXOS E DETERMINAÇÕES

\section{$\begin{array}{ll}\text { CATEGORIAIS } & 134\end{array}$}

3.1. A fundamentação ontoprática do conhecimento e a gênese do reflexo científico 135

3.1.1. Breves notas sobre as relações entre ontologia e ciência 144

3.2. Totalidade, complexos e determinações

3.2.1. O complexo geográfico 158

CAPÍTULO 4 - GEOGRAFIA DO PROCESSO DE INDIVIDUAÇÃO 178

4.1. A superação das "barreiras naturais" e o processo de individuação 178

4.2. Configurações territoriais da geografia rural e individuação restringida nas formações

4.3. Capital, geografia urbana e individualidade moderna 196

4.3.1. Um excurso teórico: homem e indivíduo na antropogeografia ratzeliana 208

CONSIDERAÇÕES FINAIS

REFERÊNCIAS BIBLIOGRÁFICAS $\quad 227$ 


\section{APRESENTAÇÃO}

A presente pesquisa objetiva, através da investigação dos momentos constitutivos essenciais da ontologia estatutária marxiana ${ }^{1}$, especificar e problematizar categorialmente aspectos concernentes à geografia da individualidade histórico-social e ao processo de individuação. Buscamos recuperar a problemática complexa da individualidade humanosocial na obra de $\operatorname{Marx}^{2}$ a partir de um eixo delimitado: onde $e^{3}$ se constitui e como se relaciona, objetiva e subjetivamente, com os lugares concretos em que se realiza. Nesse sentido, o objeto efetivo da pesquisa é composto por um conjunto delimitado de obras aquelas na quais o pensador comunista alemão, no embate radical com a realidade de sua época e as teorias que a refletiam, intenta sua autocompreensão e, assim, termina por estabelecer os princípios ontológicos fundamentais do ser social, quais sejam, os Manuscritos econômico-filosóficos de 1844, A ideologia alemã (em conjunto com $\mathrm{F}$. Engels), de 1845-6, e os Grundrisse, de 1857-8. A análise dessas obras é realizada, então, com o fito de reter e sopesar estes princípios e categorias destacando analiticamente o âmbito da relação do ser social, indivíduo e gênero, com o meio geográfico ${ }^{4}$ que produz (e, por conseguinte, imprime determinações concretas e historicamente específicas, associadas aos modos de produção e reprodução da vida material), no intrincado, contraditório e infinito processo de humanização, de sua autoconstituição.

\footnotetext{
${ }^{1}$ Reservamos o termo marxiano em referência ao pensamento de Marx, às suas próprias obras escritas de meados de 1843 até 1883; já o termo marxista identifica todos aqueles, inclusive Engels, que se apropriam, desdobram, atualizam (ou mesmo deformam) suas categorias fundamentais. Por sua vez, quanto à noção de estatuto ontológico, desdobrada posteriormente, vale reter, de início, que o reconhecimento do caráter ontológico do pensamento marxiano implica igualmente em averiguar sua particularidade não tradicional, isto é, não temos a instituição de categorias abstratas, universais e ahistóricas, tal como nas metafísicas antiga e medieval, mas o reconhecimento de determinações essenciais, historicamente constituídas, dos modos de ser do ser social: "A ontologia marxiana não é um sistema abstrato de verdades absolutas ao feitio tradicional, mas um estatuto teórico, cuja fisionomia é traçada por um feixe de lineamentos categoriais enquanto formas de existência do ser social" (CHASIN, 2001, p. 13). Dentre outros, Ivo Tonet (2013) desdobrou tal problemática.

2 "Tema este que, no mais das vezes, encontrou, mesmo em autores marxistas de extrema relevância e de competência intelectual comprovada, um certo desentendimento" (ALVES, 2001, p. 255).

${ }^{3}$ Sem receio de incoerência, em trabalho que pretende retomar a crítica (na medida em que esta não pode ser confundida com a refutação simples) da tradição geográfica, podemos retomar a Jean Brunhes (1962, p. 416): "os geógrafos devem sempre se esforçar para constatar com exatidão onde se produz o fenômeno estudado". Temos, ainda: "há um conceito fundamental da geografia - o da localização - que com certa largueza de linguagem pode ser considerado um de seus fatos basilares" (BACKHEUSER, E. 1944, p. 399). ${ }^{4}$ Mais uma vez podemos retomar uma noção clássica: "a expressão de meio geográfico é mais compreensiva que a de meio físico; ela engloba não somente as influências naturais que podem-se exercer, mas ainda uma influência que contribui para formar o meio geográfico, o ambiente total, a influência do próprio homem" (DEMANGEON, 1982, p. 52).
} 
A fim de melhor explicitar a justificativa e os objetivos da pesquisa, vale uma advertência inicial, em certa medida comum às pesquisas deste tipo: reconhecer a existência de um "pensamento geográfico" marxiano não implica, necessariamente, a tentativa de enquadrá-lo nas divisões acadêmicas e disciplinares modernas ou contemporâneas - que, em geral e na sua variedade, no campo das ciências humanas, constituíram-se posterior e contra os movimentos de trabalhadores e suas ideias comunistas (os quais, no pensamento de Marx, conquistaram sua expressão mais profunda e consciente); portanto, contra aquilo que o comunista alemão melhor representava: a assunção da lógica onímoda do trabalho ${ }^{5}$, na forma histórica específica da emergência, enquanto agente sociopolítico autônomo e independente, do proletariado urbano no cenário sociopolítico da Europa Ocidental e, nas últimas décadas do século XIX, Oriental ${ }^{6}$. Assim, para além da ciência geográfica ${ }^{7}$, tomamos um critério ontológico para a definição da geografia, enquanto uma dimensão da realidade objetiva - a morfologia e ordenação territorial dos seres, processos e relações; como define, por exemplo, Pedro Pinchas Geiger (2003, p. 7): "as formas dos objetos e fenômenos que formam a superfície terrestre". Especificando, tomamos como ponto de partida o reconhecimento de que "pensamento geográfico é geografia em pensamento, ou pensar geografia é ter para si a existência e a importância do geográfico presente na realidade" (MARTINS, 2009, p. 13, grifo do autor). Em termos um tanto distintos, mas que podem ser aproximados no essencial, temos que "por pensamento geográfico entende-se um conjunto de discursos a respeito do espaço que substantivam as concepções que uma dada

\footnotetext{
${ }^{5}$ Para além da defesa de uma perspectiva classista específica, o movimento socialista europeu do século XIX expressava a "razão do trabalho como potência central de uma dada ação política, que faz política para além da mera razão política" (CHASIN, 1987, p. 52), isto é, que perspectiva a emancipação humana. ${ }^{6}$ Cf., por exemplo, para o caso específico da sociologia, LUKÁCS (1981). Para a própria geografia, são diversas as obras que, de maneira crítica, apontaram a relação de seu desenvolvimento institucional com as demandas sociopolíticas concretas da Europa oitocentista; comentaremos algumas delas, inclusive, na sequência do trabalho, de modo que vale, aqui, referir a algumas das fundamentais: LACOSTE (2007), Milton SANTOS (1980, em especial pp. 13-97), CAPEL (2013) e MORAES (2002).

${ }^{7}$ Entendida como uma manifestação particular e específica do pensamento geográfico, cuja mediação fundamental reside na sistematização, institucionalização e consequente configuração enquanto comunidade acadêmica de especialistas: "A ciência pode ser vista como um conjunto de procedimentos especificamente definidos. E procedimentos são ações e tarefas práticas. Trata-se da construção de um certo tipo de conhecimento, aquele que definimos como científico" (MARTINS, 2009, p. 15). De modo que "discutir o discurso geográfico enquanto ciência é, portanto, fazer uma delimitação bem restritiva, em termos históricos e culturais, acatando várias particularizações. As geografias espontâneas do cotidiano e o saber geográfico incrustado em mitos e na literatura ficam de fora dessa orientação, que exprime uma epistemé própria - em termos genéticos - da cultura ocidental (cuja difusão se opera na ocidentalização do mundo)" (MORAES, 2005, p. 25). Mais adiante, abordaremos e desdobraremos, em relação a essa primeira definição, a noção de ciência.
} 
sociedade, num momento determinado, possui acerca do seu meio (desde o local ao planetário) e das relações com ele estabelecidas" (MORAES, 1996, p. 32). Dedicamos o terceiro capítulo para a discussão desse entendimento.

Em suma, distinguir um conhecimento do geográfico na obra marxiana não corresponde à identificação de um "Marx geógrafo", de uma tematização autônoma sobre algum aspecto (o "objeto") da realidade natural ou social, destacada da totalidade à qual pertence pela subjetividade cognoscente. Do mesmo modo que, por exemplo, apontar para inexistência em sua obra de uma gnosiologia ou metodologia de talhe tradicionais, demanda indicar a existência de uma forma específica de abordar os problemas relativos ao conhecimento humano e científico ${ }^{8}$. Ao contrário, com efeito, tal reconhecimento (da existência de um pensamento geográfico marxiano) corresponde tão somente à percepção de que, em seu intento de "crítica implacável à realidade existente" (carta a Ruge de setembro de 1843), no escopo de sua transformação revolucionária, Marx tematizou aspectos essenciais da realidade geográfica de seu tempo, isto é, repondo a fim de explicitar a definição acima indicada, da "realidade fáctico-material de disposição e organização dos objetos e seres na superfície do planeta" (MORAES, 2005, p. 23) ${ }^{9}$. Bem como ao entendimento de que, na constituição de seu estatuto ontológico - igualmente distinto do perfil das ontologias tradicionais e condição sine qua non da resolução da crítica supracitada - abordou e problematizou tópicos das estruturas morfológicas, topológicas e territoriais dos seres, processos e relações, em especial no tocante ao processo de formação e desenvolvimento das categorias essenciais do ser social, na exata medida em que "qualquer pretensão de responder à pergunta ontológica sobre o ser do homem ou o ser social, necessariamente terá de constituir um conhecimento de natureza geográfica e histórica" (MARTINS, 2009, p. 31) ${ }^{10}$. Ademais, a presente pesquisa não implica na busca de um "Marx geógrafo" igualmente porque, "na verdade, o geográfico remete, para sua compreensão e entendimento, a um questionamento da ordem do saber e sua divisão disciplinar" (MARTINS, 2009, p. 31) - elemento indubitavelmente presente na obra marxiana, como aponta um dos geógrafos mais destacados que tencionaram

\footnotetext{
${ }^{8}$ Como o faz, dentre outros, CHASIN (2009), no tópico 3, "A resolução metodológica".

${ }^{9}$ Caso para o qual podemos citar considerações sobre a questão da renda territorial, da circulação capitalista e do desenvolvimento desigual, amplamente desenvolvidas, entre várias outras, em obras como David HARVEY (2013) e Neil SMITH (1988).

${ }^{10}$ Para o qual podemos referir às considerações acerca das distintas características e funções das cidades nas formações comunitárias antigas (greco-romanas e germânicas), nas feudais e na sociabilidade capitalista, apenas para ficarmos com um exemplo específico
} 
exatamente essa compreensão, "em Marx, é ao mesmo tempo uma virtude e uma dificuldade que tudo se relacione a todo o resto" (HARVEY, 2013, p. 35).

Feita a advertência necessária, e problematizando as razões de se retomar um projeto que, como veremos, data da passagem à década de $1970^{11}$ (quando não de antes ${ }^{12}$ ), vale então destacar que este trabalho pretende inserir-se no projeto $^{13}$, urgente e necessário, de fazer emergir o pensamento de Marx de seu "destino trágico", que condenou, por exemplo, questões relativas à ontologia, à individualidade e individuação como externas e exteriores à sua lógica - projeto este que tão somente germinava, a partir das contribuições de Lukács, quando da crítica ao pensamento geográfico "tradicional”. Com efeito, para o pensamento marxista em geral, nesta recuperação do pensamento marxiano, “o desafio que está colocado diante de nós é tentar ao menos a recuperação e o desenvolvimento da inteligência que venha a distinguir individuação de individualismo" (VAISMAN, 2009, p. 444, grifo da autora). E, nesse sentido, coadunamos com a afirmação de que

\begin{abstract}
A pesquisa da questão do indivíduo na obra marxiana se impõe como um dos problemas mais necessários, tanto por ser uma das esferas mais deturpadas da análise marxiana, quanto porque o devido entendimento das determinações essenciais da individualidade humana, desveladas por Marx, é crucial para a compreensão do processo histórico e, por conseguinte, do devir humano (TEIXEIRA, 1999, p. 175) ${ }^{14}$.
\end{abstract}

Em suma, e teremos oportunidade de melhor explicitar este posicionamento, o projeto de uma incorporação do pensamento de Marx às discussões geográficas mostrase ainda válido na medida em que o pensamento mesmo do comunista alemão tem sido objeto de uma recente e rica recuperação e problematização ${ }^{15}$, nas quais se evidencia sua abordagem enquanto uma ontologia do ser social. Nesse sentido, tal distinção - entre individuação e individualismo - destaca a radicalidade da posição teórica de Marx que, em contraponto às "robinsonadas"16 características do pensamento liberal, compreende a

\footnotetext{
${ }^{11}$ Como veremos, significativa é a publicação de A justiça social e a cidade, de David Harvey, em 1973.

${ }^{12}$ Horacio CAPEL (2013, p. 143), por exemplo, assinala que "quando, em 1976, Yves Lacoste anunciava, no $\mathrm{n}^{\circ} 1$ de Heródote, que a geografia marxista estava 'sem dúvida a ponto de aparecer', Bernard Kayser criticava: 'Faz trinta anos que nos foi dito que a geografia marxista está a ponto de aparecer! E quando se viu a geografia dos países que tem adotado a ideologia marxista!?”.

${ }^{13}$ Também muitas vezes, e através de distintos diapasões, apresentado/defendido ao longo da história do marxismo.

${ }^{14}$ Quanto à deturpação, em outro dos poucos textos dedicados ao tema, Adam SCHAFF (1967, p. 57) afirma: "a falta das respectivas investigações na literatura marxista fez, no decorrer de décadas, com que se fixasse na cabeça dos homens um determinado estereótipo do marxismo, em cujo dicionário não há lugar para o problema do indivíduo humano".

${ }^{15}$ Que buscamos abordar em nosso segundo capítulo.

16 Termo utilizado por Marx, como veremos mais adiante, para designar a posição teórica, em especial, dos
} 
individualidade não como ponto de partida originário da história, mas como constructo resultante de um intrincado e contraditório processo $^{17}$.

Ademais, a questão que nos ocupa mais diretamente toca dimensões centrais do cenário teórico contemporâneo, bem como de suas lutas políticas e sociais. De um lado, vale reter que as tentativas de transição ao socialismo em formações sociais nas quais as relações sociais capitalistas e, consequentemente, as forças produtivas encontravam-se pouco desenvolvidas desaguaram em inviabilidades flagrantes, expressas naquilo que István Mészáros e José Chasin caracterizaram como pós-capitalismo ${ }^{18}$. Dentre as diversas dimensões da inviabilização do projeto revolucionário socialista, fundado em ideias marxistas, tem-se a degradação desse próprio corpus teórico (a deturpação supracitada) e nessa degradação, por sua vez, destaca-se o coletivismo, o entendimento do socialismo como submissão do indivíduo ao coletivo, à classe ou ao povo que pertence e, por conseguinte, o descarte da questão do indivíduo como afeita às teorias pequenoburguesas. De outro lado, a partir da intensificação da mercantilização da vida social, na esteira da restauração capitalista representada pelas políticas neoliberais e da consolidação do processo da globalização capitalista, espraiando-se por todas as esferas e dimensões da vivência humana, estabelece-se uma explícita regressão dos padrões civilizatórios mais básicos, arduamente conquistados na órbita do capital pelas lutas dos trabalhadores, sintetizada exatamente na expansão e acentuação do individualismo ${ }^{19}$. Se seguimos a caracterização de Antonio Carlos Robert Moraes, podemos considerar que certos desdobramentos recentes da ciência geográfica, em especial com a hegemonia do que chama de "geografias pós-modernas", a converte num exemplo do predomínio do individualismo, na medida em que acabam

economistas clássicos que pressupõem como fatos o que deveriam explicar e supõem um "estado primitivo originário": basicamente a existência dada de indivíduos isolados, proprietários privados e contrapostos uns aos outros na competição mercantil. István MÉSZÁROS (2009), especialmente no capítulo 3, "O ponto de vista da individualidade isolada", discute aspectos concernentes ao "individualismo metodológico", ressaltando que "seja qual for a medida de suas diferenças em outros aspectos, no que tange à questão do ponto de vista social as considerações de Marx podem ser aplicadas a todas as filosofias que se originam nas fundações materiais do capital” (p. 47).

17 "O ser humano só se individualiza pelo processo histórico" (MARX, 2011, p. 407).

${ }^{18}$ Sobre a definição de pós-capitalismo, CHASIN (1989, p. 185) destaca a "determinação de um quadro regido pelo capital, mas cuja forma de sociabilidade descartara o capitalismo". Veja-se, ainda, I. MÉSZÁROS (2002, pp. 1012-1062), e J. CHASIN (1987). Deste último, destaque-se, ainda, a noção de capital coletivo/não-social.

${ }^{19}$ No quadro da estruturação não de uma "sociedade do consumo", mas de uma "cultura do consumo", bem como com a "dissolução de antigas identidades sociais (classistas), a atomização e a pulverização imediatas da vida social, as novas 'sensibilidades' produzidas pelas tecnologias da comunicação", dimensões que, associadas às transformações mais profundas da nova ordem capitalista, "erodiu os sistemas constituídos de vinculação e inserção socias" (NETTO, 2010, p. 15) 
por reificar as singularidades do presente histórico, ao desconectá-las radicalmente de um passado tido como (teórica e ontologicamente) superado. Paradoxalmente, a crítica radical da modernidade faz o elogio de sua essência: o indivíduo autocentrado no mundo global sem sentido e em constante transformação (MORAES, 2006, p. 42).

No sentido posto, acrescer um par de citações pode auxiliar a esclarecer e justificar este trabalho, isto é, a explicitação de uma abordagem da questão da individualidade a partir de um marco teórico que usualmente é posto como seu inviabilizador e numa dimensão mais específica - a geográfica. Começando por José Chasin (2000, p. 130, grifo meu), ao reconhecer que, na posição marxiana, a própria individualidade

sendo condensação e síntese, resultante de si própria pela mediação infinita com as demais de seu gênero, na esfera interativa com todos os gêneros, implica tal ordem de complexidade que seu estudo isolado é pura abstração, de modo que chegar concretamente a ela obriga a perfazer caminhos sem fim.

Distintamente da abordagem em certa medida generalizada, que toma como referência uma individualidade "descarnada", e reatando com nosso ponto de partida (as considerações acerca da geografia como dimensão da realidade), impõe-se a hipótese de se a consideração da geografia da individualidade (dos lugares em que esta se realiza e como se relaciona com estes lugares) corresponde a um desses caminhos que permitem a elucidação da sua complexidade e, assim, dos rumos de sua constituição. Em outras palavras, talvez a hipótese em tela possa ser associada ao intento de acrescentar "alguns itens à teoria do mundo invertido, que reforçam o projeto da reinversão desse mundo e completam o projeto marxista de uma revolução na organização industrial por um projeto de revolução urbana" (LEFEBVRE, 1999, p. 97), isto é, o de pôr em primeiro plano "os problemas relativos aos lugares concretos onde se exercem as relações sociais" (LEFEBVRE, 1999, p. 97). Em suma, retenha-se a questão: para se compreender o indivíduo (sua consciência e seu desenvolvimento), ainda que se leve em consideração as determinações biológicas e econômicas (de trabalho), pode se desconsiderar "a morfologia e as formas exibidas pelos lugares, a relação entre esses lugares e as instituições (a escola, a universidade, a empresa, o exército, o Estado etc.)?”. No que vale, inclusive, a compreensão de que "a introdução da topologia (considerações analíticas sobre as topias no espaço mental e social) permite reter a amplitude filosófica das concepções, eliminando as sequelas da atitude filosofante (especulativa)" (LEFEBVRE, 1999, p. 98). Problematizar os lugares em que o processo de individuação se realiza e "desrealiza”, a relação das individualidades concretas com esses lugares (sua consciência e prática espaciais), a partir da ontologia do ser social, permite, assim, tanto contribuir para a redescoberta do pensamento de Marx como atentar para aspectos decisivos em 
direção à retomada das lutas sociais no contexto contemporâneo, evitando considerações abstratas especulativas.

Mediando para a discussão dos objetivos da presente dissertação (mas ainda evidenciando elementos de sua justificativa), vale perceber que representa, em certa medida, a continuidade e o desdobramento de nossa pesquisa de monografia Geopolítica elna geografia didático-escolar ${ }^{20}$. Ali, identificamos a limitação da renovação da geografia didático-escolar no âmbito específico da geopolítica. Vimos, então, que o conceito de estado erigido por F. Ratzel (1844-1904), além de, como sabido, presente nos textos clássicos da tradição geopolítica, parece igualmente guiar certas análises e explicações na maior parte dos textos didáticos e paradidáticos de Geografia produzidos nos últimos anos, assim como a ausência de uma fundamentação teórica explícita e problematizada associava-se a uma diversidade temática e o encaminhamento para a discussão mais geral das "atualidades". Apontávamos, simultaneamente, a necessidade da incorporação de categorias básicas e textos clássicos do marxismo como condição da crítica interna e subversão do pensamento geográfico tradicional - no caso, abordamos a concepção de estado sintetizada na obra A origem da família, da propriedade privada e do Estado, de F. Engels (1820-1895). Pretendemos, então, nessa dissertação, ampliar o leque de diálogo e alterar o foco de nossa análise: incorporar as obras fundamentais da ontologia marxiana e sua questão decisiva - o problema da individuação.

Remeter à nossa monografia, nesse momento, permite ressalvar o fato de que este trabalho igualmente origina-se de preocupações associadas ao ensino da geografia, ainda que a este âmbito específico não direcione seu foco. Em suma, enquanto docente da disciplina $^{21}$ deparei-me com a manutenção de características identificadas e criticadas ao longo do processo de renovação crítica ${ }^{22}$ da disciplina - escolar e científica - dentre elas, principalmente, a fragmentação dos conteúdos, a ênfase na memorização e o afastamento da realidade (dos educandos ou dos homens em geral). Com efeito, tal permanência tem

\footnotetext{
${ }^{20}$ Apresentada como pré-requisito para aprovação no curso de especialização de Ensino de Geografia, na PUC-SP.

${ }^{21}$ Grife-se, sem a formação específica para tal (o que, inclusive, nos levou ao curso de especialização e à própria graduação na área), e tendo nos livros didáticos o principal meio de acesso ao saber geográfico institucionalizado, nesse caso, o escolar.

${ }^{22}$ A justificativa da opção por esse termo pode ser encontrada em Astrogildo Luiz de FRANÇA FILHO, (2012). Pretendemos, mais adiante, desdobrar esses aspectos. Utilizaremos, ao longo do trabalho, também a noção de "ensaio de ruptura", presente em Jorge Luiz Barcellos da SILVA (1996).
} 
sido objeto de estudos e debates em pesquisas e encontros de professores de geografia ${ }^{23}$. Dentre estes, Lana de Souza Calvacanti (2011, p. 11), por exemplo, reconhece que

Embora haja um significativo desenvolvimento da pesquisa e da produção científica sobre a prática de ensino e no âmbito específico do ensino de Geografia, é sabido que os avanços teóricos obtidos têm chegado muito lentamente à prática escolar, que permanece em boa parte respaldada em concepções teóricas tradicionais, tanto do ensino quanto da Geografia.

São várias as dimensões do saber institucionalizado que necessitam ser problematizadas e abordadas na busca da compreensão sobre as limitações da renovação da disciplina - inclusive, e talvez fundamental, a sua própria institucionalização ${ }^{24}$. Em certa medida, acreditamos ter desdobrado, na monografia aludida, um desses elementos num aspecto particular: o livro didático, especificamente a partir da geopolítica e sua (não) inserção. Dada a dimensão da problemática, e sem a pretensão de responder conclusivamente às questões, pretendemos, enquanto objetivo específico, na presente dissertação, lançar luzes sobre os avanços teóricos da geografia acadêmica - na medida que eles igualmente registram certos limites e impasses - em especial na consideração sobre suas relações com o pensamento de Marx, resguardada a problematização de seus fundamentos teóricos e metodológicos como o objetivo mais geral. Acreditamos, resumidamente, que o aprofundamento do debate acerca do movimento de renovação da disciplina - e de seus fundamentos e impasses teóricos - possa contribuir para compreender seu relativo bloqueio, bem como propiciar elementos para sua continuidade, e sobre isso dedicamos, no primeiro capítulo, algumas reflexões. Procuramos tracejar, ali, em grandes linhas, a (relativa) crise que se explicita na ciência geográfica na passagem da década de 1960 à de 1970 e a crítica que então se desenvolve. Problematizamos os lineamentos de uma crítica ontológica e os limites verificados na própria crítica e renovação. Atravessa esta discussão, a percepção do papel do marxismo nessa crítica.

Tal como esquadrinhado sumariamente, este trabalho insere-se no âmbito da interação entre ciência e filosofia, mais especificamente, entre ciência geográfica e ontologia no âmbito do marxismo, referencial teórico-metodológico da pesquisa. Tratase de uma aproximação recente no contexto da tradição científica e, em certa medida, ainda em constituição ${ }^{25}$. Também o desvelamento do caráter ontológico do pensamento

23 Aspecto problematizado, dentre outros, por Beatriz ZANATTA (2003), Maria Adailza Martins ALBUQUERQUE (2011), Jorge Luiz Barcellos da SILVA (2013).

${ }^{24}$ Como discutiu, recentemente, por exemplo Breno Viotto PEDROSA (2013).

${ }^{25}$ Comprovamos tal aspecto, em especial, na participação das discussões no GT 11 - Filosofia e Epistemologia em Geografia, no último Enanpege (2013), no qual foi reconhecida pela maior parte dos 
marxiano, como comentamos, é igualmente recente - G. Lukács dedica-se a tal tarefa nos anos finais de sua longeva existência, durante a década de 1960, com o abandono do projeto de redação de uma Estética marxista e a percepção da necessidade de redação de uma introdução à sua Ética, projeto que desejava executar originariamente. Os resultados desse esforço materializam-se em duas obras (Para uma ontologia do ser social, em dois volumes, e Prolegômenos a uma ontologia do ser social) publicadas postumamente, ao longo da década de 1970, que ainda carecem de uma maior apropriação mesmo no âmbito do marxismo ${ }^{26}$.

A temática, assim, como um todo, mostra-se um campo ainda complexo e movediço $^{27}$, dentro do qual objetivamos nos mover com cuidado. Para tanto, tomamos o processo de constituição do pensamento próprio de Marx - através do que José Chasin identificou como as três críticas ontológicas instauradoras (à política, à filosofia especulativa e à economia política) - como a rota para abordagem e problematização dos lineamentos fundamentais da ontologia do ser social ali constituída (de maneira originária e, em certa medida, inicial, a ser ainda enriquecida em sua trajetória intelectual). Buscamos, então, especialmente caracterizar, em primeiro lugar, a noção de crítica filosófica (instituída pelo próprio Marx e problematizada por Chasin como crítica ontológica) a fim de verificar sua apropriação para a reflexão acerca da ciência geográfica. Ademais, pretendemos também explicitar a concepção de homem erigida nesse momento (na qual o processo da individuação assume inegável centralidade, ainda que apenas retomado, no âmbito do marxismo, nas últimas obras do filósofo húngaro) e as possibilidades de determinação da geografia enquanto dimensão da realidade.

participantes tanto a necessidade de uma maior explicitação dos fundamentos teórico-metodológicos nas discussões realizadas no próprio grupo de trabalho, em especial no tocante à problemática e relações entre ontologia e epistemologia, como a do equacionamento das vias de interlocução das discussões ali realizadas com as objetivadas em outros grupos de trabalho: em suma, a problematização do papel dos estudos e pesquisas em Teoria e Método da Geografia para os rumos concretos da disciplina. Por sua vez, em termos de "tradição, os protagonistas principais deste debate foram e são Armando Corrêa da Silva, pioneiro nessa preocupação, e Milton Santos, este último deixando valiosa contribuição acerca do assunto na primeira parte de seu trabalho A natureza do espaço. É possível citar ainda Antônio Robert Moraes e Ruy Moreira. O primeiro, num único e breve texto já bastante antigo, abandona em momento subsequente sua posição em favor da possibilidade de uma ontologia do espaço. Já Ruy Moreira, mais recentemente, apresenta uma posição algo distinta dessa tradição" (MARTINS, 2007, p. 33).

${ }^{26}$ No caso do Brasil, por exemplo, apenas nos momentos finais dessa pesquisa (novembro de 2013), foi lançada a cuidadosa tradução para o português do Para uma ontologia do ser social II, completando a edição nacional dessas obras fundamentais iniciada em 2011 com os Prolegômenos.

${ }^{27}$ Ainda mais quando levamos em conta a avaliação de Lukács (2012, p. 29), referendada por Chasin, de que "não há até o presente uma história da ontologia". 
Acreditamos que acompanhar as críticas efetuadas por Marx às três dimensões centrais da realidade de seu tempo possibilita alcançarmos os objetivos delineados na medida em que, intimamente vinculadas desde sua emergência - entre os anos de $1843 \mathrm{e}$ 1844 -, potenciam-se ao longo de toda a trajetória intelectual de Marx resultando numa concepção própria do mundo e do homem, isto é, as três críticas fundadoras

\begin{abstract}
não se esgotaram nessa função originária, mas permaneceram ativas como momentos essenciais do projeto de intelecção de mundo armado por Marx. É da integração das mesmas que redunda o teor e o caráter do novo patamar de inteligibilidade proporcionada pela síntese filosófico-científica engendrada pela reflexão marxiana (CHASIN, 2009, p. 74).
\end{abstract}

O terceiro capítulo constitui, simultaneamente, um desdobramento do anterior e a busca de sua vinculação com o primeiro. A partir do entendimento da especificidade do pensamento de Marx e de sua ontologia, busca-se evidenciar como o problema das relações entre ontologia e ciência é colocado em um novo patamar para que, então, se possa compreender a centralidade do processo de individuação, enquanto resultado da própria história humana, associado à produção de um mundo humano cuja dimensão geográfica, ou territorial, constitui uma de suas determinações. Nesse momento, a investigação se detém, fundamentalmente, em duas obras: Manuscritos econômicofilosóficos e A ideologia alemã , nas quais é possível identificar a recaracterização radical das categorias de sujeito e objeto ${ }^{28}$. Além de outras obras de Marx - artigos e livros produzidos neste período ou em outros, que auxiliam na sua contextualização - pretendese lançar mão de obras de estudiosos que se voltaram ao resgate do pensamento próprio de Marx, dentre os quais destacamos Marx - Estatuto ontológico e resolução metodológica, de José Chasin.

Por fim, o quarto capítulo explicita, de maneira concreta, o andamento histórico e geográfico do processo de individuação. Busca-se compreender, ainda com ênfase na obra marxiana (tanto A ideologia alemã, mas incorporando também os Grundrisse, outra obra inacabada voltada para sua autocompreensão), os complexos geográficos que conformam distintos tipos de individualidades, e como estas se relacionam com aqueles. Neste momento, acentuamos a interação com diferentes matrize ${ }^{29}$ da ciência geográfica,

\footnotetext{
28 “O tratamento diferenciado dos mesmos só virá a emergir, de modo explícito e elaborado, nas páginas dos Manuscritos econômico-filosóficos e de $A$ ideologia alemã " (José CHASIN, 2009, p. 91). Assim, é fundamental grifar que refutamos qualquer possibilidade de distinção entre um "jovem" ou "velho" Marx posterior aos anos de 1843-44, isto é, o Marx pré-marxiano corresponde, na periodização explicitada por Chasin, exclusivamente àquele que se manifesta na tese doutoral de 1841 e nos artigos da Gazeta Renana de 1842. Posição crítica a tal entendimento foi recentemente reposta por Armando BOITO JÚNIOR (2013). ${ }^{29}$ Noção apresentada e desenvolvida por Moreira (2009).
} 
na medida em que não contrariem a lógica essencial do pensamento de Marx e, por fim, realizamos um excurso teórico pela obra ratzeliana, no sentido de propiciar a apreensão de seus nexos com a situação histórica e geográfica da sociabilidade e individualidade modernas. 


\section{CAPÍTULO 1 - CARACTERIZAÇÃO DA QUESTÃo: INDIVÍDUO E MARXISMO NA CRÍTICA DA GEOGRAFIA}

Conforme posto na Apresentação, objetiva-se, neste capítulo, identificar os fundamentos e determinações mais gerais da crise da geografia (explicitada de uma forma específica nos anos finais da década de 1960) e da crítica, fundamentalmente de caráter político-ideológico, então desenvolvida. Busca-se, assim, problematizar o modo - e com qual fundamentação teórica - como as concepções de homem e de indivíduo presentes na ciência "tradicional" são criticamente discutidas no seio do movimento de renovação crítica da disciplina, momento no qual avulta a noção de ideologia. Constatamos a emergência de lineamentos de uma abordagem ontológica que, essencialmente, busca destacar os nexos da concepção de homem com o contexto social em que se constitui e, por fim, apresenta-se o debate em torno da verificação dos próprios limites e impasses do movimento de renovação (inclusive como essa verificação se associa com a avaliação do marxismo, sua base teórica hegemônica, mas não única).

\subsection{A CRISE DA GEOGRAFIA...}

Nos anos finais da década de 1960 explicita-se de maneira decisiva a situação crítica em que se encontrava e debatia a ciência geográfica: "neste momento se discutem os impasses gerados pelo próprio projeto da geografia enquanto um segmento do saber científico capaz de dar conta, compreender e explicar, enfim, os problemas concretos que se inscrevem no espaço geográfico em que vivemos" (GONÇALVES, 1982, p. 94).

Em realidade, a fragmentação da disciplina (refletindo a fragmentação geral do saber e expressando a falência de seu projeto original, inserido no âmbito do holismo humboldtiano ${ }^{30}$ ou mesmo da postura hologeica de F. Ratzel ${ }^{31}$ ) e sua incapacidade de estabelecer um vínculo coerente, e, portanto, explicativo, entre os diferentes elementos

\footnotetext{
${ }^{30}$ Ruy MOREIRA (2006; 2010) e Antonio Carlos VITTE (2006), através de vias distintas, vêm se destacando na retomada de sua obra.

31 Marcos Bernardino de CARVALHO (1998), no quadro da rediscussão da obra ratzeliana que comentaremos mais adiante, vem se dedicando a ressaltar este aspecto do pensador prussiano.
} 
(ou "fatos", como tradicionalmente se caracterizam, "físicos" ou "humanos") da realidade vinha sendo, de há muito, apontada e criticada. Jean Dresch (1980, p. 11), por exemplo, em 1948, afirmava:

A descrição geográfica abandona o lugar de enumeração dos fatos, escolhidos mais ou menos arbitrariamente, mais ou menos isolados no abstrato. Quantas monografias regionais não se reduzem a uma acumulação de dados, classificados segundo uma ordem estabelecida, conduzindo o leitor até a estrutura geológica e, de passagem, ao habitat, ao relevo, à hidrografia, ao clima, à vegetação, ao povoamento, aos gêneros de vida, uma verdadeira série de tiradas em sequela!

Ou seja, já quando os geógrafos buscavam, ao menos, outro tipo de engajamento - mais crítico e socialmente referenciado ${ }^{32}$, no quadro do que Pedrosa denomina dos "geógrafos de esquerda" 33 - a estrutura "tradicional" do saber geográfico (fundada numa articulação incoerente e justaposta entre elementos da natureza inorgânica e orgânica, da população/povoamento e da economia de uma determinada área, isto é, na estrutura NH-E) mostra-se inconsistente e incapaz de fornecer o referencial teórico-metodológico necessário. Dresch critica, portanto, a geografia científica tal como se consolidou nas primeiras décadas do século XX, em especial na realização de monografias regionais e expressa pelo que tradicionalmente se reconheceu como a "escola geográfica francesa"34.

No entanto, ainda que as limitações centrais do pensamento geográfico fossem já identificadas e apontadas com precisão, e, em certa medida, também já se indicasse a necessidade de outros parâmetros teóricos, é comumente reconhecido que os "geógrafos de esquerda" mantiveram-se, em geral, nos quadros do positivismo tradicional. François Dosse (1994, p. 349), historiador das ciências sociais, aponta, acerca da primeira abordagem "marxista" (ou assim auto-reconhecida), de Pierre George, Jean Dresch e Jean Tricart, que "marcados pela geografia tradicional e prisioneiros do seu empirismo, esses geógrafos não lograrão abalar sua disciplina nem abri-la para um questionamento epistemológico sobre seus fundamentos ou para diálogos interdisciplinares". Ao contrário, se acompanhamos a caracterização de Lacoste (1974, p. 236), é a "expansão

\footnotetext{
32 De um modo mais geral, associada ao desenvolvimento da "revolução quantitiva", tal revisão representa a emergência de um novo momento do modo de produção capitalista.

${ }^{33}$ Cf. PEDROSA, 2013, pp. 77-130. Trata-se do importante e conhecido grupo da Geografia Ativa.

${ }^{34}$ Vale remeter ao recente movimento de rediscussão da obra de Paul Vidal de La Blache, reconhecidamente o principal representante e orientador da chamada "escola francesa" (noção à qual destinamos, logo adiante, alguns comentários críticos). ROBIC; OZOUF-MARIGNIER (2012) e Guy MERCIER (2012) são bons exemplos desse reposicionamento. A recente publicação de Vidal, Vidais: Textos de Geografia Humana, Regional e Política, coligindo artigos dispersos e traduzindo outros é um fato importante para tal processo na geografia brasileira. De todo modo, vale perceber que mesmo Lacoste (2007, p. 248) apontava para a riqueza e a contraditoriedade da obra de La Blache, podendo-se compreender que temos uma espécie de seleção, no âmbito da tradição francesa, de alguns aspectos, em detrimento de outros, de seu pensamento.
} 
dos elementos geográficos do discurso que estão mais em contato com as ciências econômicas e sociais", representada exatamente pelo grupo da Geografia Ativa e pelo consequente desenvolvimento, na França, da geografia econômica e da geografia urbana, que resulta na acentuação do corte entre os "fatos físicos" e os "fatos humanos". Com efeito, segundo Lacoste (1974, p. 237), “um pequeno número de geógrafos influenciados pelo marxismo preocupa-se com os efeitos da dominação colonial nos 'países ultramarinos' e esforça-se por trazer uma contribuição ao estudo do "subdesenvolvimento", tratando-se, portanto, de "novas preocupações [que] levam os 'geógrafos humanos' a fazerem empréstimos cada vez mais numerosos aos demógrafos, aos sociólogos, aos urbanistas e, sobretudo, aos economistas, enquanto os 'geógrafos físicos' se iniciam nos métodos cada vez mais precisos dos geólogos ou dos meteorologistas", de modo que torna-se "cada vez mais importante e evidente o corte entre esses dois partidos de geógrafos" (LACOSTE, 1974, p. 237) - os "físicos" e os "humanos".

De todo modo, tais geógrafos apontavam para o fato de que na prática tinha-se "cada vez mais a negação do projeto unitário" 35 . Desdobra Lacoste, com o que podemos perceber a semelhança em relação à crítica de Dresch:

Ora, devemos constatar que na maioria dos casos, na maior parte dos cursos e dos manuais de 'geografia regional', esta análise das interações é, de fato, uma enumeração numa certa ordem $-1^{\circ}$ ) relevo, $2^{\circ}$ ) clima, $3^{\circ}$ ) vegetação, $4^{\circ}$ ) rio, $5^{\circ}$ ) população etc. - dos diferentes elementos de discursos tomados de empréstimo às outras disciplinas, justapostos uns aos outros (LACOSTE, 1974, p. 226).

Quaini, em livro lançado um ano após o artigo supracitado, em 1974, sintetiza os principais elementos que patenteiam a crise do discurso geográfico tradicional, a partir de Claval, Gambi e o mesmo Lacoste: a representação caótica da realidade, a ausência de organicidade e substancial carência de lógica e rigor científico "que parecem inelimináveis da geografia que nos foi transmitida pela geração precedente" (QUAINI, 1979, p. 12).

É certo afirmar, assim, que os fundamentos filosóficos e conceituais da disciplina não são reformulados ou mesmo criticamente problematizados até meados da década de

\footnotetext{
35 Título de um dos tópicos do conhecido artigo "A geografia”, de Yves LACOSTE, reelaborado no capítulo "Uma prática universitária que é, cada vez mais, a negação do projeto global” de A geografia - isso serve, em primeiro lugar, para fazer a guerra.
} 
$1970^{36}$, no quadro da explicitação da crise mesma da disciplina. No entanto, é fundamental perceber que

qualquer esforço no sentido de desvendar a natureza da crise de um determinado segmento do espaço do saber deve, portanto, partir da premissa de que o trabalho intelectual, embora possuindo uma dinâmica específica, sofre influência do próprio contexto histórico que constitui a materialidade do trabalho científico (GONÇALVES, 1982, p. 93) ${ }^{37}$.

Nesse sentido, a compreensão da crise da geografia demanda a percepção de sua inserção no contexto mais geral de crise da sociabilidade do capital em seus dois subsistemas $^{38}$, tal como se expressa exatamente no período citado. Em suma, à percepção de que temos, "desde a passagem da década de sessenta à de setenta, a crise do ‘capitalismo democrático' (como quer Przeworski), na sua acabada configuração que é o Estado de bem-estar social" (NETTO, 2001, p. 67-8) ${ }^{39}$, iniciando a crise global do capital $^{40}$, que logo se espraia e configura-se terminal para as formações pós-capitalistas decorrentes da experiência soviética. Horácio Capel (2013, p. 113) destaca exatamente a centralidade da crise social para compreensão das transformações no pensamento geográfico, na medida em que "no interior dos países desenvolvidos capitalistas e nos de sua periferia próxima, tornaram-se visíveis novos problemas sociais que exigiam novas respostas por parte dos cientistas. Em geral, pode-se dizer que a década de 1960 vê aumentar os conflitos no meio das sociedades capitalistas" 41 .

\footnotetext{
${ }^{36}$ Inclusive porque, como também é reconhecido, a outra "renovação" proposta, contemporânea à Geografia Ativa, isto é, a Geografia Quantitativa, "atinge mais a linguagem do que o conteúdo e o método específico, esta operação, que se explica em larga medida em razão das novas necessidades da programação econômica e territorial, se resolve, salvo poucas exceções, numa relação com os problemas reais, que é, sim relativamente nova, (porque a nível tecnocrático) mas não crítica e, afinal, serve de apoio e está subordinada às escolhas dos centros decisórios" (QUAINI, 1979, p. 12)

De outro lado, processo análogo pode ser identificado na trajetória da geografia brasileira, com suas particularidades: a emergência de novas temáticas, socialmente referenciadas, e a identificação da necessidade de novos referenciais teóricos efetiva-se já na década de 1940 com a formação de geógrafos como Pedro Pinchas Geiger e Orlando Valverde (para citarmos apenas alguns), mas problematização crítica efetiva dos referenciais teóricos tradicionais proceder-se-á apenas ao longo da década de 1970.

${ }^{37}$ Publicado em 1981, o artigo “Abordagem contextual”, de Vicent BOURDOULAY (2003), de perspectiva teórica distinta à de Gonçalves, sintetiza posições acerca da problematização do contexto na historiografia da geografia.

${ }^{38}$ Termo utilizado por José CHASIN (cf. 1989, pp. 178-199) para caracterizar a dinâmica da crise tanto em seu polo capitalista como no pós-capitalista.

${ }^{39} \mathrm{O}$ que explicita, para o mesmo autor, "o fracasso do único ordenamento sócio-político que, na ordem do capital, visou expressamente compatibilizar a dinâmica da acumulação e da valorização capitalista com a garantia de direitos políticos e sociais mínimos" (NETTO, 2001, p. 68))

${ }^{40}$ É exatamente nesse momento, especificamente em 1971, que se pode afirmar que "o status quo social de pouco tempo atrás vem se desintegrando rápida e dramaticamente diante de nossos próprios olhos - basta querer ver" (MÉSZÁROS, 1987, p. 33).

${ }^{41}$ Também SOJA (1993, p. 67) destaca que “o mundo lá fora, entretanto, estava mudando depressa. As cidades, regiões e Estados eram cada vez mais tomados pelo conflito, pela crise e pelos primórdios de uma
} 
O geógrafo espanhol inventaria os efeitos mais expressivos desses conflitos e de maior influência no pensamento geográfico, desde as "decisivas mudanças que se produzem nas relações políticas internacionais como resultado da culminação do processo descolonizador" (CAPEL, 2013, p. 112) - e seus subsequentes desdobramentos, como a constituição do movimento dos países não alinhados (Conferência de Bandung, 1955), a problematização do subdesenvolvimento como resultado de "toda configuração do sistema de dominação imperialista" e a "aparição de movimentos revolucionários no Terceiro Mundo", com os quais "a crise do sistema mundial de dominação europeianorte-americana" se desdobra e "alcança seu ponto culminante com a Guerra do Vietnã" (CAPEL, 2013, p. 113) ${ }^{42}$ - até os movimentos ecológicos - "que prontamente se convertem em movimentos críticos do modelo de sociedade" -, não deixando de destacar a emergência dos movimentos sociais urbanos - que traduzem "a degradação da vida nas cidades, convertidas em simples espaços para a reprodução da força de trabalho" e “estendem a impugnação desde o campo da produção ao das condições da vida em geral" (CAPEL, 2013, p. 114) ${ }^{43}$ - materializados igualmente na crítica da vida cotidiana. Enfim,

profunda reestruturação".

${ }^{42}$ Exemplo paradigmático, aqui, é o de Yves Lacoste, que inicia seu trabalho de campo em geomorfologia em Argélia, logo abandonado pela problematização da estagnação e do "subdesenvolvimento", abordada em suas obras Os Países Subdesenvolvidos (1959) e Geografia do subdesenvolvimento (1965). É esclarecedor, ainda, reconhecer a trajetória que o encaminha às problematizações de caráter mais teórico, associadas ainda às questões levantadas por Capel: "Geógrafo, sim, mas eu me preocupava bem pouco com a epistemologia. Depois de haver escrito sobre a geografia do subdesenvolvimento encarada no plano mundial, com uma metodologia que incluía tanto de geografia quanto de história, de economia ou demografia, fui levado a intervir em campo, em diversos países do terceiro mundo, especialmente em situações de crise mais ou menos graves e dramáticas, como a brutal erosão dos solos no centro do AltoVolta (Burkina Fasso) onde a população cresce rapidamente, como o bombardeamento em 1972 dos diques no delta do rio Vermelho, no Vietnã, pela aviação norte-americana. Confrontando essas urgências, diante de desafios como esses, fui obrigado (de início de maneira mais empírica, quase instintiva) a analisar com maior eficácia os problemas e recomendar maneiras de ação diferentes, dissociando (para em seguida articular) o que se poderia ver e fazer em pequenos espaços, lugares precisos, por um lado e, por outro lado, em territórios mais amplos. /.../. Logo em seguida formulei de maneira mais teórica esse método, baseado na distinção sistemática de níveis diferentes de análise espacial, baseado na distinção sistemática de níveis diferentes de análise espacial, desde os conjuntos de dimensões planetárias, que só se apreendem com muita abstração, até as situações concretas, passando pelos conjuntos de ordem de grandeza intermediária", narra o próprio Lacoste, para concluir: "responsabilidades em campo e reflexões mais teóricas levaram-se a questionar a geografia e sua razão de ser" (LACOSTE, 1989, p.182 e 183, o grifo é meu). De outro lado, pode-se reconhecer que toda a obra de Milton Santos, desde especialmente $O$ trabalho do geógrafo no terceiro mundo, de 1971, é atravessada pela busca de compreensão e crítica das relações de subordinação do então chamado Terceiro Mundo.

${ }^{43}$ Associado à questão dos direitos civis, a trajetória de David Harvey pode ser mais diretamente conectada a tais movimentos. Comentando sobre sua ida a Baltimore, a partir de 1969: "na passagem para a década de 1970, havia um significativo movimento antiguerra, além de ativismo pelos direitos civis em torno da universidade. Desde o início, a própria cidade de Baltimore me intrigou. De fato, era um lugar extraordinário para se realizar um trabalho empírico. Rapidamente, envolvi-me em estudos de discriminação em projetos de moradia, e, desde então, a cidade formou uma tela de fundo para boa parte do meu pensamento" (HARVEY, 2005, p. 21). 
também Yves Lacoste (1974, p. 233) ressalta que "a tomada de consciência de que uma crise fundamental se está processando procede do fato e que as relações homem-natureza aparecem cada vez mais como tendo essência dialética", de modo a referir a uma "crise global de nosso tempo" - expressa pelas, em seus termos, crise das relações homemnatureza (ecológica), crise demográfica, crise urbana e, também, pela "formidável acentuação das desigualdades entre os homens, combinando-se ela com a multiplicação e com a aceleração dos fenômenos relacionais entre grupos humanos outrora separados por distâncias frequentemente consideráveis" (LACOSTE, 1974, p. 234).

É este quadro complexo e conflituoso, problematizado em ampla e conhecida bibliografia, que "deu lugar ao nascimento de uma nova esquerda nos Estados Unidos e na Europa, ao pipocarem conflitos de classes e ao nascer uma atitude crítica em que a

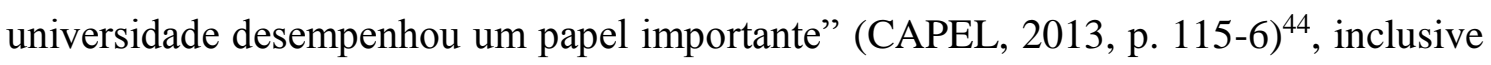
como meio para emergência de um setor crítico apartado do movimento socialista (já hegemonizado pelo stalinismo) que cristalizava-se e deteriorava-se com a própria crise do pólo pós-capitalista ${ }^{45}$. Nesse sentido, a apreensão da crise da geografia como um momento da crise mais ampla da totalidade capitalista permite igualmente compreender sua relação com a emergência de um movimento crítico ${ }^{46}$ igualmente mais amplo. Ou seja:

\footnotetext{
44 ' $O$ meio acadêmico estava ficando mais politizado - e aceitavelmente 'radical' - do que fora, em muitos anos, na América do Norte e na Grã-Bretanha; e o discurso teórico havia começado a se voltar significativamente contra o positivismo, em direção a alternativas críticas extraídas das 'grandes linhagens' da teoria social europeia continental" (SOJA, 1993, p. 67).

${ }^{45}$ Trata-se, ainda que tal discussão mereça certa problematização, impossível aqui, da consolidação do que Perry ANDERSON (2004, p. 63), em texto já clássico, caracteriza como "marxismo ocidental", ainda que possamos problematizar tal categoria, no qual destaca: "a stalinização dos partidos criados pela Terceira Internacional a partir do final da década de 1920, burocraticamente organizados e ideologicamente subordinados às políticas da URSS, deixou uma marca inconfundível no marxismo".

46 Tomando-se como referência a realidade brasileira, por exemplo, em que se destaca, ainda, a especificidade da "transição transada" (Florestan Fernandes) controlada pelo regime bonapartista, é elucidativo perceber a contemporaneidade de movimentos de renovação em diferentes setores profissionais, tão vinculados ao Estado como os geógrafos. Enquanto é tomado como marco o ENG de 1978 (que encerrase, em verdade, em 1979), para o serviço social, por exemplo, tem-se o III Congresso Brasileiro de Assistentes Sociais, em 1979, que será conhecido como o Congresso da Virada, demarcado pelo enfrentamento e denúncia do conservadorismo profissional e de seu vínculo com o Estado, bem como por sua abertura e busca de associação com a classe trabalhadora brasileira (cf., NETTO, 2004). Também na pedagogia, é explícito a busca de novos caminhos, em especial com a apropriação do pensamento marxista. Além da consolidação, ao longo da década de 1970, das teorias que Saviani veio a denominar como críticoreprodutivistas (a de Althusser, por exemplo, também de importante influência na geografia), tem-se o processo de organização profissional - "o contexto do final da década de 1970 era de busca de alternativas. Em 1978 houve um seminário de educação brasileira em Campinas. Nele ainda é possível perceber como a visão crítico-reprodutivista era predominante. Mas em 1979 as três principais entidade da área educacional, que acabavam se ser constituídas, unem-se para organizar a série das conferências brasileiras de educação" (SAVIANI, 2008, p. 137, a I Conferência Brasileira de Educação realizar-se-á em 1980), no bojo do qual é proposta, pelo mesmo Saviani, a pedagogia histórico-crítica.
} 
O conjunto da práxis e da teoria científica se viu, logicamente, afetado por estes desenvolvimentos, e assim, desde os fins dos anos 1950 e logo durante a década de 1960, começaram a aparecer, nas disciplinas sociais, correntes críticas que geralmente se designam a si mesmas como 'radicais', afirmando, com isso, sua pretensão de uma mudança radical, que fosse até a raiz (CAPEL, 2013, p. 116).

Capel destaca o pioneirismo dessas correntes críticas na economia e na sociologia, sinalizado pela publicação de A economia política do crescimento, de Paul Baran, em 1957, a partir do qual "de forma explícita, aceitou-se a teoria marxista, mas pretendeu-se superar a análise do capitalismo realizada por Marx, já que esse havia se fundamentado no pressuposto de uma economia competitiva" e buscou-se "uma reflexão crítica que renega o trabalho de todos os economistas anteriores, aos que acusa de realizar uma tarefa mistificadora" (CAPEL, 2013, p. 117). Tal movimento, que se consolida em revistas como Monthly Review, New Left Review e Review of radical political economics, espraiase logo para as demais disciplinas sociais, tanto nos Estados Unidos como na Europa Ocidental: “em geral, existe neles uma vontade pública de integrar a teoria marxista como alternativa frente às análises acadêmicas tradicionais” (CAPEL, 2013, p. 118).

A leitura de Capel pode ser referendada e transposta à geografia a partir de Richard Peet (1982, p. 225) que, em 1977, ao relatar "os principais eventos no recente desenvolvimento de um movimento radical na Geografia nos E.U.A.”, aponta, de saída, duas pressuposições básicas - primeiro que "toda Ciência, e especialmente a Ciência Social, serve a algum propósito político; segundo, que a função da ciência convencional, estabelecida, é servir o sistema social estabelecido, convencional e, de fato, permitir-lhe sobreviver" - para asseverar que "a ciência radical é, então, o agente consciente da mudança política revolucionária. E a Geografia Radical é uma parte dela, partilhando a mesma aspiração" (PEET, 1982, p. 226). Ou seja, e concretizando, com a eclosão das “cidades centrais dos E.U.A" e das mobilizações contrárias à Guerra do Vietnã, em meados dos anos 1960, “o grito de batalha tornou-se 'relevância' - que significou mudar o tópico focal da disciplina, mantendo ainda a metodologia de pesquisa existente" (PEET, 1982, p. 231-2), de modo que, a partir de 1967, “compromissos foram assumidos /.../ e desde a metade dos anos sessenta, nas revistas começaram a aparecer artigos tratando sobre aspectos obviamente geográficos das questões sociais” (PEET, 1982, p. 232), materializando-se, em 1969, na fundação da revista Antipode ${ }^{47}$.

\footnotetext{
47 "Nesse contexto de mudança, algumas partes da geografia moderna também começaram a se radicalizar, lideradas pelos que contribuíam para o novo jornal Antipode e inspiradas numa série de viradas esquerdistas
} 
Dessa forma, podemos destacar um elemento central: os distintos movimentos nacionais - que assim se mantiveram, a despeito dos diferentes graus de interpenetração de autores, ideias, temas e problemáticas - de renovação da ciência geográfica academicamente institucionalizada podem ser tomados, essencial e primeiramente, como uma mudança de postura dos intelectuais e de suas relações com as forças sociais e políticas. É assim que também reconhecem, por exemplo, dois protagonistas que, no bojo da geografia brasileira, situam-se em polos diametralmente opostos, inclusive mesmo na aceitação da noção de "geografia crítica": Douglas Santos e José W. Vesentini.

O primeiro, por exemplo, em entrevista em 2008, afirma que, para além de qualquer identidade teórico-metodológica, aliás, inexistente, "o movimento redefiniu as forças políticas e o formato da realização do diálogo entre os acadêmicos e os diferentes públicos externos que, de uma maneira ou de outra, vão ter contato com a produção do discurso geográfico em todo esse período (isto é, daquela época até os dias de hoje)” (SANTOS, D.; 2008, p. 36). Enfim,

o que existiu foi um movimento, criado quase que espontaneamente, que mobilizou - em diferentes escalas e com diferentes posicionamentos - os geógrafos /.../ com o objetivo explícito de provocar mudanças (ou impedir que acontecessem) que reverberassem no interior da sociedade brasileira, tanto no que se refere aos fundamentos de nossa formação econômica e social, quanto à expressão materializada da violência política da ditadura de plantão (SANTOS, D.; 2008, p. 36-7).

Vesentini aponta o mesmo elemento, no que vale a citação completa:

A geografia crítica, no final das contas, foi aquela - ou, mais propriamente, aquelas, no plural - que não apenas procurou superar tanto a geografia tradicional quanto a quantitativa, como principalmente procurou se envolver com novos sujeitos, buscou se identificar com a sociedade civil, tentou se dissociar do Estado (esse sujeito privilegiado naquelas duas modalidades anteriores de geografia, a tradicional e a pragmática) e se engajar enquanto saber crítico - isto é, aquele que analisa, compreende, aponta as contradições e os limites, busca contribuir para um projeto de autonomia - nas reivindicações dos oprimidos, das mulheres, dos indígenas, dos afrodescendentes e de todas as demais etnias subjugadas, dos excluídos, dos dominados, dos que ensejam criar algo novo, dos cidadãos em geral, na invenção de novos direitos (VESENTINI, 2009, p. 128, grifo do autor).

Esta distinta postura ético-política, enfim, aponta para a superação da identificação tradicional e quase que imediata do pensamento geográfico sistematizado 
com o Estado ${ }^{48}$. Daí a importância fulcral da obra-manifesto de Lacoste, de modo que Ruy Moreira, tomando como referência a geografia brasileira, possa afirmar se tratar da

fase lacosteana da renovação: denúncia da geografia do professor, o discurso do saber 'neutro, inútil, ingênuo e desinteressado', discurso que esconde na 'paisagem-obstáculo' a face do seu real comprometimento, e denúncia da geografia dos estados-maiores /.../. Crítica ideológica que já nasce com cara de crítica política (MOREIRA, 2000, p. 36).

Com efeito, são centrais, nesse primeiro passo da renovação crítica da disciplina, os questionamentos sobre a função da geografia: "para que(m)" ela serve, como anuncia/responde o próprio título da obra referência desse período ${ }^{49}$. Com o que, em realidade, temos a busca de outros parâmetros práticos para o conhecimento geográfico, outras formas de aplicação desse saber a partir de sua vinculação com distintos sujeitos sociais e/ou forças políticas - associação com movimentos políticos (partidos de esquerda e congêneres, como agrupamentos de combate à ditadura, no caso brasileiro) e sociais (movimentos urbanos, ecologistas, anti-imperialistas etc.), ou simplesmente um engajamento intelectual mais crítico e socialmente referenciado (por vezes, até, de cariz liberal). Richard Peet, em seu conhecido artigo supracitado, fornece exemplos interessantes ao discutir as práticas de "expedições e advocacias" nas quais a geografia estadunidense engaja-se na passagem da década de 1960. É igualmente nesse sentido que, em alguns autores, como Lacoste, o ensino - meio através do qual o saber geográfico ganha dimensão social mais profunda, isto é, através do qual a maior parte das pessoas entra em contato com esta parcela do conhecimento científico e, por consequência, a mesma desenvolve, de maneira explícita, alguma função social - consiste em elemento central de reflexão (ainda que nem todos os geógrafos produzam diretamente suas ideias para esta dimensão).

A partir daí, dessa busca de novas possibilidades de engajamento prático dos geógrafos, isto é, de "uma nova relação com a sociedade que seja ao mesmo tempo ativa e crítica" (QUAINI, 1979, p. 12), que os limites da ciência geográfica produzida até então evidenciam-se de forma cada vez mais explícita e são refutados pelos próprios estudantes ou "iniciantes" 50 ."De fato, a geografia é hoje rejeitada na medida em que se mostra

\footnotetext{
${ }^{48}$ Identificação de longa data e à qual podemos retomar, inclusive, a própria origem da sistematização e institucionalização do saber geográfico no quadro daquilo que Yves Lacoste virá a caracterizar como "Geografia dos Estados-Maiores".

${ }^{49}$ E também o título da introdução, escrita por Ruy Moreira, seu organizador, da coletânea Geografia: Teoria e crítica (1982) - "O saber geográfico: para que/quem serve?"

${ }^{50}$ Assim, Quaini se refere ao fato de que, quando não se abriam a transformações quase que impostas pelos
} 
incapaz de apreender os problemas cuja gravidade, pouco ou muito, cada um começa a avaliar, pela ação dos mass-media. A geografia não está em condições de fornecer uma descrição do mundo que responda às nossas preocupações” (LACOSTE, 1974, p. 236).

Vale perceber que a busca da problematização das razões desses limites (como vimos, em certa medida igualmente presentes na crítica de Jean Dresch) efetiva-se, agora, coetânea ao estabelecimento de novos parâmetros teórico-filosóficos. Com efeito, referenciando-se pela geografia estadunidense, pode-se reconhecer que "a partir de 1972, a ênfase da Geografia Radical mudou de uma tentativa de engajar a disciplina em pesquisa socialmente relevante para uma tentativa de construir uma filosofia radical e uma base teórica para uma disciplina engajada social e politicamente" (PEET, 1982, p. 238). Tratase, nesse caso e acompanhando a trajetória das ciências sociais à época, da guinada para o marxismo: "esta base foi crescentemente encontrada na teoria marxista, que alguns geógrafos britânicos tinham lido no final da década de 1960, e muitos geógrafos dos E.U.A começaram a ler no início da década de 1970" (PEET, 1982, p. 238) ${ }^{51}$. Em relação à geografia francesa, Yves Lacoste aponta que "o fato de numerosos geógrafos começarem a tomar consciência da crise da geografia provoca, a partir de alguns anos, uma série de reflexões sobre sua disciplina. Mas essas reflexões ainda são, em grande parte, mais metodológicas do que epistemológicas" (LACOSTE, 1974, p. 241), com o que reforça a necessidade de superar a "surpreendente carência epistemológica" 52 da geografia universitária, no intento da "difícil tarefa, que é a construção dos conceitos fundamentais para a geografia" (LACOSTE, 1974, p. 242).

Uma das primeiras e mais importantes obras ${ }^{53}$, publicada em 1973, a expressar a busca por uma filosofia radical e uma base teórica para uma disciplina engajada social e politicamente é A justiça social e a cidade, de David Harvey. A obra, em realidade, expressa exatamente o trânsito ideológico do próprio geógrafo britânico, até então um

alunos, as aulas de geografia eram simplesmente abandonadas. Nesse sentido, o caso brasileiro é paradigmático por contar com uma central participação dos estudantes, cf. ANTUNES; SOUSA NETO (2008) e PEREIRA (2008).

${ }^{51}$ Também com referência à geografia anglófona: "Apesar de inicialmente mais heterogênea, a geografia radical deslocou-se rapidamente para uma dedicada marxificação da análise geográfica, novamente liderada por Harvey" (SOJA, 1993, p. 68).

${ }_{52}$ Título de mais um subtítulo do artigo.

${ }^{53}$ Como afirma o próprio autor em entrevista: "No início da década de 1970, havia um tipo de movimento muito difundido entre estudiosos mais jovens da geografia para pesquisar essa dimensão específica. Social justice and the city foi um dos textos que registrou esse momento, tornando-se um ponto de referência, à medida que o tempo passava" (HARVEY, 2005, p. 24). 
expoente da Geografia Quantitativa, e divide-se em duas partes - "Formulações liberais" e "Formulações socialistas" 54 - trazendo, nesta última, contribuições específicas ao que nos interessa mais diretamente no momento: a crítica da ciência geográfica. Além de alguns comentários na introdução e conclusão do trabalho, apenas o capítulo IV - "A Teoria Revolucionária e Contra-Revolucionária em Geografia e o Problema da Formação do Gueto" -, introdutório à segunda parte, toca em questões relativas propriamente à ciência, mas de grande importância e profundidade, a nos permitir, exatamente, a síntese das reflexões anteriores e a transição para a problematização mais efetiva da crítica realizada, bem como a compreender as razões de seu embasamento no marxismo ${ }^{55}$.

Com efeito, Harvey abre o capítulo problematizando a questão que igualmente nos toca no momento: "como e por que tentaríamos chegar a uma revolução no pensamento geográfico?” (HARVEY, 1980, p. 103); a partir da qual estabelece um diálogo crítico com as ideias de Thomas Khun acerca das "revoluções científicas" e dos paradigmas no pensamento científico. Harvey, de saída, aponta para o aspecto problemático mais central das ideias do físico estadunidense: "a abstração do conhecimento científico de sua base materialista" (HARVEY, 1980, p. 104), mesmo no tocante às ciências naturais; bem como indica sua preocupação: a compreensão dos "contornos extras", das especificidades para aplicação da teoria de Kuhn às ciências sociais.

Quanto ao primeiro aspecto, após pontuar que "Kuhn oferece uma interpretação idealista do progresso científico", Harvey afirma, seguindo Bernal: "a atividade material envolve a manipulação da natureza no interesse do homem, e o entendimento científico não pode ser interpretado independentemente dessa imposição geral" (HARVEY, 1980, p. 104, grifo nosso). O geógrafo britânico busca, assim, encontrar as raízes para

\footnotetext{
${ }^{54}$ Na mesma entrevista: "Nos Estados unidos, fui então chamado de liberal legítimo. Desse modo, comecei adotando essa linha. Depois, achei que não esta funcionando. Assim, passei a adotar formulações marxistas para ver se produziam melhores resultados. Não premeditei a mudança de uma abordagem para outra; tropecei nela" ((HARVEY, 2005, p. 22) Vale anotar, porém, o reconhecimento do próprio autor dos limites de sua leitura da obra de Marx, fato que apresenta, aliás, como comum à época. Acerca de um grupo de estudos de $O$ capital, organizado em 1971, afirma: "na ocasião não era marxista, e sabia muito pouco sobre Marx. Era um período em que ainda não havia muita literatura marxista disponível em inglês" (HARVEY, 2005 , p. 22). Comentando seu trabalho posterior, The limits to capital, recentemente publicado no Brasil, reconhece: "No entanto, para ser honesto, ao escrever The limits do capital, fixei-me nos próprios textos de Marx na maior parte do tempo. Depois de Social justice and the city, percebi que não entendera Marx e precisava corrigir isso, o que tentei fazer sem muita ajuda de outros autores" (HARVEY, 2005, p. 24-5, grifo meu).

${ }^{55}$ Discussão, nos parece, importante para os dias atuais, como veremos adiante, nos quais, em diversos setores da geografia, Marx e o marxismo têm sido criticados ou refutados sem serem conhecidos. Cf. CARLOS (2007).
} 
compreender duas contradições básicas nas postulações de Kuhn: 1. não explica porque surgem anomalias que transbordam em crises e abalam determinados paradigmas (para o que Harvey aponta a importância de se diferenciar "anomalias significativas" e “insignificantes”, sendo as primeiras aquelas de caráter relevante à aplicação do sistema teórico, ou paradigma, no contexto cotidiano, na prática social: “por isso, o paradigma newtoniano permaneceu satisfatório e inquestionável até que algo relevante e de importância prática não pudesse ser realizado, usando-se o sistema newtoniano" (HARVEY, 1980, p. 104)) e 2. também não explica as razões da aceitação de um novo paradigma (para Kuhn, segundo Harvey, tal aceitação residiria num "ato de fé" nunca devidamente examinado, de modo que pode-se entender que "o ato de fé, aparentemente, baseia-se na crença de que o novo sistema permitirá a extensão da manipulação e controle de algum aspecto da natureza" (HARVEY, 1980, p. 104)). David Harvey desdobra sua argumentação, ainda sobre esse aspecto, buscando precisar a noção de "manipulação e controle de algum aspecto da natureza", presente nesta última citação, e a de "interesse do homem", grifado na citação no início do parágrafo, questionando qual aspecto da natureza necessita ser controlado e reconhecendo que o “'interesse do homem' está sujeito a uma variedade de interpretações, dependendo de que setor da sociedade estamos tratando" (HARVEY, 1980, p. 104). Quanto ao anterior, deve-se reconhecer que "a coalização da indústria e governo afeta fortemente a atividade científica. Consequentemente, 'manipulação e controle' significam manipulação e controle no interesse de grupos particulares da sociedade (especificamente, a comunidade industrial e financeira junto com a classe média) mais do que no interesse da sociedade como um todo" (HARVEY, 1980, p. 104-5). Tem-se, enfim, o reconhecimento (anteriormente comentado a partir de Peet) da associação da ciência, e especialmente da "ciência oficial", com os interesses sociais dominantes, mesmo para o caso das ciências naturais.

$\mathrm{Na}$ sequência de sua problematização, Harvey busca a compreensão dos "contornos extras" da teoria das "revoluções científicas" quando aplicada às ciências sociais. Dentre estes destaca a percepção de "um movimento baseado em revolução e contra-revolução, em contraste com as ciências naturais, para as quais a noção não parece tão imediatamente aplicável” (HARVEY, 1980, p. 107), a partir do qual toca no que nos parece um elemento essencial: “a questão é que a ciência social formula conceitos, categorias, relações e métodos que não são independentes das relações sociais existentes. 
Como tais, os conceitos são o produto dos verdadeiros fenômenos que eles se destinam a descrever" (HARVEY, 1980, p. 107).

Destaquemos esse ponto - os conceitos, no âmbito das ciências sociais em especial, são o produto daquilo, das relações sociais, que pretendem descrever - pois parece-nos tratar-se de uma dimensão que escapa nas posições que vieram a se constituir hegemônicas no movimento de renovação da ciência geográfica. Harvey já havia abordado tal questão na "Introdução", em temática igualmente central, quando seu “argumento ontológico é ontológico, procurando resolver a questão 'o que é o espaço?"” (HARVEY, 1980, p. 5). Após apresentar sucintamente as diversas formas de compreensão do espaço - enquanto absoluto, relativo ou relacional -, assevera: "o problema da correta conceituação do espaço é resolvido através da prática humana em relação a ele. Em outras palavras, não há respostas filosóficas para as questões filosóficas que surgem sobre a natureza do espaço - as respostas estão na prática humana" (HARVEY, 1980, p. 5). Isto é, adiantando a radical perspectiva materialista que está a desdobrar no capítulo que analisamos, o geógrafo britânico afirma que os diferentes conceitos de espaço originam-se nas práticas humanas. "A relação de propriedade, por exemplo, cria espaços absolutos dentro dos quais o controle monopolístico opera", respondendo à necessidade de medição e estabelecimento de limites absolutos. Outras práticas e relações demandam, por suposto, outros conceitos de espaço e é isso que merece ser grifado: para Harvey, os conceitos enraízam-se na atividade sensível dos homens. Em seus termos, é necessário

\footnotetext{
entender como a atividade humana cria a necessidade de conceitos espaciais específicos, e como a prática social e cotidiana resolve, com aparente tranquilidade e perfeição, os mistérios filosóficos profundos relativos à natureza do espaço e às relações entre o processo social e as formas espaciais (HARVEY, 1980, p. 5$)^{56}$.
}

Retornando à problematização do conhecimento científico, o geógrafo britânico desdobra tal aspecto tomando como referência a relação entre as teorias de Adam Smith, David Ricardo e Marx, de um lado, e deste último com a economia marginalista, de outro. Quanto à primeira relação, a teoria de Marx constitui uma verdadeira revolução na medida em que, ainda que partindo de um problema colocado pela teoria anterior - o valortrabalho e a origem da mais-valia - coloca-a como "chave para a compreensão de toda a produção capitalista" (ENGELS apud HARVEY, 1980, p. 108), de modo que

\footnotetext{
${ }^{56}$ Desdobraremos esta questão no capítulo 3.
} 
a teoria marxista era, nitidamente perigosa porque fornecia a chave do entendimento da produção capitalista, da posição daqueles que não controlavam os meios de produção. Consequentemente, as categorias, conceitos, relações e métodos que tinham o potencial de formar novo paradigma eram uma enorme ameaça para a estrutura de poder do mundo capitalista (HARVEY, 1980, p. 109).

E, por sua vez, a economia marginalista comparece rejeitando os conceitos fundamentais da economia clássica e, portanto, também da própria economia marxista. Tal dinâmica contra-revolucionária é identificada por Harvey também na teoria marxista russa após a morte de Lênin e, vale destacar, na cooptação

de grande parte da linguagem marxista na sociologia Ocidental (tanto que alguns sociólogos sugerem que todos somos marxistas agora), sem considerar a essência do pensamento marxista, [que] evitou efetivamente o verdadeiro florescimento do pensamento marxista e, concomitantemente, a emergência daquela sociedade humanizada que Marx visualizou. Tanto os conceitos como o projetado relacionamento social contido nos conceitos foram frustrados (HARVEY, 1980, p. 109).

A conclusão da citação é essencial: se os conceitos enraízam-se em relações sociais determinadas, são concomitantes a inviabilização das novas relações sociais e da teoria crítica que as fundamentam e propugnam, isto é, "as revoluções no pensamento não podem em última instância ser separadas das revoluções na prática" (HARVEY, 1980, p. 109). Vários desdobramentos dessa reflexão são possíveis para o objeto direto de nosso trabalho - tanto para a compreensão da igual vinculação da teoria dominante com as relações dominantes (outra faceta da associação, registrada acima, entre o conceito e a realidade que busca descrever) como para a discussão dos próprios limites que se evidenciarão da crítica que então se anuncia e aprofunda. Porém, sigamos a reflexão de Harvey e "retornemos agora à questão inicial. Como e porque tentaríamos chegar a uma revolução no pensamento geográfico", após estas “introspecções” teóricas. E, nesse momento, Harvey é explícito: mesmo com a consolidação da "renovação" representada pela "revolução quantitativa", uma nova revolução é necessária pois o paradigma dominante mostra-se incapaz de responder aos problemas sociais concretos. Em suma: "há clara disparidade entre a teoria sofisticada e a estrutura metodológica que estamos usando e nossa habilidade em dizer qualquer coisa significativa sobre os eventos tais como eles se desenvolvem em torno de nós" (HARVEY, 1980, p. 110). Disparidade e dilema que se acentuam com a explosão dos conflitos sociais, conforme vimos anteriormente (e perceba-se que o rol elencado é o mesmo de Capel e Lacoste): "há um problema ecológico, um problema urbano, um problema de comércio internacional, e não obstante parecemos incapazes de dizer qualquer coisa de fundo ou profundidade sobre qualquer deles. Quando realmente dizemos alguma coisa ela parece trivial e talvez 
ridícula" (HARVEY, 1980, p. 110). E conclui, decisivamente: "são as condições sociais objetivas emergentes e nossa patente inabilidade em combatê-las que essencialmente explicam a necessidade de uma revolução no pensamento geográfico" (HARVEY, 1980, p. 111).

Assim sintetizada a razão de fundo da crise da geografia, Harvey problematiza as alternativas teóricas postas ao andamento da revolução necessária: o idealismo, a fenomenologia e o marxismo, defendendo este último como mais frutífero, na medida em que possibilita a síntese de certos aspectos das demais correntes, provendo "interpretações adequadas da realidade social na qual nos encontramos" (HARVEY, 1980, p. 111). Reconhece, assim, por exemplo, que "há, também, certas coisas que o marxismo e o positivismo têm em comum. Ambos têm uma base materialista e ambos valem-se de um método analítico" (HARVEY, 1980, p. 111); aproximação específica que não deixa de ser significativa, na medida em que, como veremos, a mesma passará, no bojo da crítica à crítica marxista da geografia ${ }^{57}$, servirá de álibi à própria impugnação do marxismo. Significativa também porque Harvey não deixa de destacar a diferença essencial: "é que o positivismo simplesmente procura entender o mundo, enquanto o marxismo busca mudá-lo" (HARVEY, 1980, p. 111). E, mais à frente do capítulo, após problematizar a necessidade de uma teoria revolucionária sobre a formação do gueto urbano, Harvey explicita uma tipologia de teorias que permite aprofundar tal entendimento - e suas razões na defesa do marxismo. Afirma, então, que existem três espécies de teoria: a teoria do status quo, a teoria contra-revolucionária e a teoria revolucionária. Quanto à primeira, a teoria do status quo, temos que se trata de "uma teoria que se apoia na realidade que deseja escrever e que representa, acuradamente, o fenômeno que com ele lida em um momento particular no tempo" (HARVEY, 1980, p. 129). Ou seja, diferentemente da teoria contra-revolucionária ("que pode ou não parecer apoiada na realidade que busca retratar"), a do status quo tem como particularidade distintiva o apoiar-se na realidade, na medida em que reveste-se de um caráter prático, ainda que numa específica perspectiva, a da reprodução: "tendo atribuído status universal de verdade às proposições que contêm, é capaz de produzir políticas prescritivas que podem resultar somente na perpetuação do status quo" (HARVEY, 1980, p. 129). Por sua vez, distintamente, a teoria contra-revolucionária "obscurece, enevoa e geralmente ofusca (mesmo que por intenção ou acidente) nossa habilidade em compreender aquela

\footnotetext{
${ }^{57}$ Veremos, por exemplo, a posição GOMES (1996).
} 
realidade". Assim, ainda que seja "logicamente coerente, facilmente manipulável, esteticamente atraente, ou bastante nova e de moda" tal teoria

é de muitas maneiras bastante alheia à realidade que pretende representar. Uma teoria contra-revolucionária automaticamente frusta mesmo a criação ou a implementação de políticas viáveis. É por isso um artifício perfeito para a não tomada de decisão, porque distrai a atenção dos assuntos fundamentais para assuntos superficiais ou inexistentes (HARVEY, 1980, p. 129-30).

Por fim, o geógrafo britânico caracteriza a teoria revolucionária, formulada dialeticamente (que pode incorporar, portanto, o conflito e a contradição dentro de si), na medida em que "está firmemente apoiada na realidade que busca representar" (HARVEY, 1980, p. 130), igualmente conflituosa e contraditória. "Uma teoria revolucionária, consequentemente, provê a perspectiva para criar a verdade mais do que para encontrála" (HARVEY, 1980, p. 130). Como afirmamos, tal diferenciação nos parece importante na medida em que possibilitará melhor compreender o sentido das concepções de homem produzidas nas matrizes clássicas da ciência. Mesmo não nos sendo minimamente possível, porém, vale indicar o interesse em verificar a validade ou atualidade desta caracterização de Harvey para compreender o estágio atual da ciência geográfica e de seus embates teórico-metodológicos.

Um último aspecto deste texto de Harvey que deve ser ressalvado é como associa tal tipologia com uma questão essencial para a geografia: a divisão disciplinar. Acatando a conhecida proposição de Marx e Engels de que "a classe dominante produz as ideias dominantes", reconhece, porém, que se trata de um processo complexo e que "não há conspiração necessariamente envolvida (embora o controle da opinião, de instrução e de propaganda muitas vezes suprima ideias potencialmente revolucionárias)" (HARVEY, 1980, p. 126). Nesse sentido afirma que "toda a organização do saber (a organização do processo de aprendizagem, a estrutura do sistema educacional, a divisão do saber em disciplinas distintas etc.) também reflete os interesses dominantes na sociedade, porque estes são todos parte do processo que contribui para a reprodução da sociedade" (HARVEY, 1980, p. 127) e que "no interior das disciplinas devemos, por isso, esperar que a maioria das formulações teóricas serão do status quo ou contra-revolucionárias" (HARVEY, 1980, p. 127). Cabem, aqui, duas percepções. Em primeiro lugar, o fato de que tal compreensão justifica e demanda um novo projeto de saber, de caráter crítico e global, senão refutando a divisão disciplinar, ao menos secundarizando-a, no sentido da atenção prioritária à realidade. Se, com efeito, é posta à teoria revolucionária a imperiosidade de apoiar-se na realidade, na forma a mais concreta possível, refletindo 
inclusive suas contradições, a própria "realidade tem que ser, por isso, abordada diretamente mais do que através de formulações das disciplinas acadêmicas. /.../. Formulações genuinamente revolucionárias não podem ter base disciplinar específica; elas devem referir-se a todos os aspectos relevantes da realidade material" (HARVEY, 1980, p. 128). Em suma, vale destacar que no momento em que se afirma que "a emergência de uma verdadeira revolução no pensamento geográfico está destinada a ser temperada por um empenho para a prática revolucionária” (HARVEY, 1980, p. 126) deve-se igualmente reconhecer que "torna-se um ato de consciência revolucionária para o acadêmico desnudar-se de pressuposições contra-revolucionárias para agarrar-se à realidade que estamos designadamente tentando analisar e compreender" (HARVEY, 1980, p. 126). No entanto, e este é o segundo ponto a destacar, não temos na obra de Harvey uma maior problematização desta questão, na medida em que se direciona ao objeto específico que é a cidade. Podemos, então, identificar uma crítica mais explícita e aberta à ciência geográfica em textos seus contemporâneos, não necessariamente diretamente influenciados por ele. A esta crítica, de maneira mais direta, dedicamos o próximo tópico.

\subsection{E A SUA CRÍTICA POLÍTICO-IDEOLÓgICA: O VIÉS EPISTEMOLÓGICO}

Não pretendemos, nesse momento, a caracterização completa do complexo movimento de crítica ao pensamento geográfico que então se desdobra (como vimos, associado à busca de novo e distinto embasamento teórico-filosófico), nem algo próximo disso. Trata-se, além de um processo amplo e diverso, em certa medida ainda em aberto (tanto seu encaminhamento quanto em sua interpretação) ${ }^{58}$. Buscamos, então, a partir de seus textos fundamentais, em especial aqueles de influência na geografia brasileira, a aproximação à nossa temática específica: a questão do homem e do indivíduo. Nesse sentido, destacamos as obras de Yves Lacoste, Milton Santos e Massimo Quaini, além de

\footnotetext{
${ }^{58}$ Concordamos, em realidade, que "ainda estamos muito longe de responder objetiva e concretamente o que foi a geografia crítica no Brasil" (PEDROSA, 2014, p. 17)
} 
uma incursão pelos periódicos lançados à época, "que costuraram o imaginário das novas ideias e alimentaram o circuito das mudanças” (MOREIRA, 2010, p. 27).

Continuamos, então, ainda em 1973, ano de publicação de dois outros artigos que nos permitem avançar na caracterização da crítica então realizada à ciência geográfica, no tocante especificamente à questão da ideologia. James Anderson, na Antipode, publica "Ideologia em Geografia: uma introdução", e Yves Lacoste anuncia os eixos de sua crítica no verbete, já citado aqui, "Geografia”, em A filosofia das ciências sociais: 1860 aos nossos dias, complementados e desdobrados com A geografia - isso serve, em primeiro lugar, para fazer a guerra, em 1976.

Vale iniciar por Anderson (1977, p. 41), que explicitamente busca referenciar-se no marxismo, inclusive quando apresenta o conceito de ideologia, "empregado numa linha marxista": "simplificadamente, ideologia refere-se a sistemas de ideias que fornecem avaliações distorcidas e parciais da realidade, com o efeito objetivo, e nem sempre pretendido, de servir aos interesses parciais de determinado grupo ou classe social”. Assim, embora teça considerações críticas a Althusser, por considerá-lo um dos que "separam rigidamente" ciência e ideologia, é cristalino que Anderson mantém-se no "critério epistemológico para determinar o que é e o que não é ideologia" (VAISMAN, 1996, p. 62) - ponto de vista do qual o filósofo estruturalista francês é um dos principais representantes. Com efeito, a contraposição de Anderson em relação ao que considera uma separação rígida entre ideologia e ciência parece residir essencialmente na necessidade de se esclarecer as especificidades das ciências que tomam o homem como objeto: “opor rigidamente 'ciência' a 'ideologia' leva ao dogmatismo, e coloca a questão: o que é ciência social?" (ANDERSON, 1977, p. 45); no sentido de se perceber que, ao contrário das naturais, "na ciência social, os fetiches do capitalismo exigem que as aparências sejam demolidas para a essência ser vista" (ANDERSON, 1977, p. 45). Isto é, o que parece estar em questão, para Anderson, é questionar a noção de objetividade na ciência social, que não pode se identificar mecanicamente com as ciências naturais e necessita superar o empirismo que lhes é próprio:

Os métodos da ciência natural, particularmente a quantificação, trouxeram ganhos indubitáveis. Frequentemente, contudo, os grandes sucessos da ciência natural são creditados ao empirismo, que de fato foi responsável por alguns avanços importantes, e a quantificação, na busca de um status semelhante de sucesso para ciência social, é muitas vezes prematura e mal orientada -

\footnotetext{
${ }^{59}$ Publicado no Brasil em setembro de 1977, na Seleção de Textos 3, da AGB-SP.
} 
representando fatos difusos e isolados através de uma precisão numérica espúria (ANDERSON, 1977, p. 44).

Assim, ao criticar a contraposição rígida entre ciência e ideologia, Anderson busca, em realidade, refutar o empirismo e a quantificação excessiva no campo das ciências sociais ${ }^{60}$, pois, dada a natureza específica destas, "o empirismo, ao se confinar às aparências superficiais, ignora o fetichismo e o apoia objetivamente" (ANDERSON, 1977, p. 46). E termina por reproduzir, ainda que de maneira mais complexa e menos rígida, a contraposição entre ideologia e saber objetivo: "Como uma arma na luta de classes, o marxismo não substituiu a ideologia, mas ele se move de modo mais próximo da objetividade. /.../. Isso porque as ideologias correspondem aos pontos de vista dos vários grupos e classes cujos interesses na sociedade existente, ou incapacidade de mudála, os impede de vê-la em seu todo" (ANDERSON, 1977, p. 48).

E também no tocante às particularidades da geografia, na ideologia em geral, se explicita o critério epistemológico em sua definição, sempre se remetendo ao modo de pensar para caracterizá-las. Assim reconhecemos, em primeiro lugar, que "o 'fetichismo do espaço' é o modo de pensar particular dos geógrafos. As relações entre os grupos ou classes sociais são apresentadas como relações entre áreas, obscurecendo (como no chauvinismo) as divisões sociais no interior das áreas" (ANDERSON, 1977, p. 46). É o obscurecimento da realidade, por apresentar as contraposições e conflitos sociais como conflitos espaciais que aparece como elemento determinante. E, em segundo lugar, ao reconhecer o papel da Geografia, mais como "transmissora" ideológica do que "produtora", papel que cabe a outras disciplinas, em especial no sistema escolar, o que não implica desprezar seu significado: "a Geografia é muito importante como transmissora, de não pouca importância na educação escolar, onde ela é um veículo para a ciência social geral e onde a maioria das pessoas formam sua 'visão do mundo', se não sua “visão global'” (ANDERSON, 1977, p. 50). Em suma: a ideologia aparece como um conjunto de ideias que realizam o obscurecimento de aspectos da realidade e, de todo modo, como a transmissão de ideias.

Passemos, então, a Lacoste, abordando em conjunto o artigo de 1973 e o livro de 1976, que nos permitem, inclusive, alcançar a temática específica que nos interessa, reconhecendo, com Dosse, a importância e influência determinantes de Louis Althusser. Com efeito, no que se refere à "definição de diferentes escalas de conceituação", à

\footnotetext{
${ }^{60}$ Demarque-se: no contexto do embate com a geografia quantitativa.
} 
distinção entre "o espaço enquanto objeto real e o espaço enquanto objeto de conhecimento" e também sobre a

ligação necessária entre teoria e prática política, a referência epistemológica essencial de Lacoste é Althusser, citado explicitamente, e que serve manifestamente de modelo epistemológico para repensar ou pensar o espaço. A geografia terá sido, portanto, o último continente a ser influenciado pelo althusserianismo (DOSSE, 1994, p. 352).

O próprio Lacoste, por sua vez, destaca a influência de outro filósofo francês, o também estruturalista Michel Foucault, em especial no que se refere à "concepção moderna da epistemologia": a distinção entre ciência (stricto sensu, resultado do avanço da divisão do trabalho científico) e o saber - “cuja razão de ser é combinar, em função de uma prática, os elementos e instrumentos de conhecimento produzidos ou elaborados por diversas ciências ou por outros saberes" (LACOSTE, 1989, p. 183), raiz do reconhecimento de Lacoste de uma "Geografia dos Estados-Maiores", isto é, um saber voltado à ação política no espaço, e a "Geografia dos Professores", a ciência engendrada ao longo do século XIX.

São sumamente conhecidos os traços gerais da crítica de Yves Lacoste à ciência geográfica que se constitui no século XIX, de modo que buscaremos destacar, nesta sucinta análise, a questão de ideologia e como se relaciona com a definição do conceito de homem presente na ciência geográfica. Vale iniciar, porém, por perceber que o geógrafo francês lida com duas dimensões na abordagem da noção mesma de geografia - ontológica e epistemológica:

É claro, há geografia e geografia. Essa palavra ao mesmo tempo indica realidades ditas "geográficas" (tal cadeia de montanhas, tal grande rio, tal arquipélago que existe há milhões de anos, tal área de grande povoação, tal cidade que existe há milênios ou séculos) e as representações - não apenas cartográficas - mais ou menos parciais que os geógrafos dão delas (LACOSTE, 1989, p. 184).

Ainda que haja uma redução de não pouca importância nessa passagem - apenas os geógrafos produziriam as representações acerca das realidades geográficas - tal não se mantém nos demais textos. De todo modo, evidenciando a influência da caracterização de Foucault, o ponto central é o reconhecimento da necessidade de se "distinguir dois grandes tipos de geógrafos" na produção das referidas representações acerca da geografia do real: a supracitada distinção entre Geografia dos Estados-Maiores e Geografia dos Professores. A primeira, o discurso geográfico que "ensinava aos reis, aos príncipes, aos diplomatas, aos chefes de guerra, os conhecimentos necessários à realização de seus empreendimentos políticos e militares" (LACOSTE, 1974, p. 243). Esta “descrição 
metódica dos espaços sob seus aspectos "físicos' e 'humanos" deve ser compreendida como uma das funções básicas do aparelho de Estado, "de um lado, para o controle e a organização dos homens que povoam seu território e, do outro, para a guerra" (LACOSTE, 1974, p. 243). É, assim, um instrumento de poder. Esta caracterização aparece no tópico do artigo "A geografia" intitulado A Geografia em suas relações com a ideologia e com o poder, de modo que se a Geografia dos Estados-Maiores pode ser bem descrita como associada ao poder, é na Geografia dos Professores que podemos identificar seu papel ideológico.

Lacoste é explícito na definição das duas funções ideológicas desse discurso geográfico específico, organizado nas universidades e escolas europeias a partir da segunda metade do século XIX: "uma das funções inconscientes, é a de mascarar a importância estratégica dos raciocínios centrados no espaço" (LACOSTE, 2007, p. 31), outra, "de início", é a de mostrar a pátria, reproduzindo indefinidamente sua imagem, em cartas ou mapas, com o objetivo de apresentar o país ${ }^{61}$ como um “dado intangível”, "como se tratasse não mais de uma construção histórica, mas de um conjunto espacial engendrado pela natureza" (LACOSTE, 2007, p. 56). Enfim, a "geografia dos professores, tal como ela se manifesta nos manuais antes dos anos vinte, oculta já, com certeza os problemas políticos internos da nação, mas ela não dissimula jamais os sentimentos patrióticos que são, muito frequentemente, do mais belo chauvinismo" (LACOSTE, 2007, p. 57-8). Assim, como em Anderson, é evidente o critério epistemológico da definição de ideologia, associando-a à falsa consciência imposta, fundamentalmente, pela estrutura escolar: que mascara e oculta através do discurso ou inculca certas noções e imagens, no caso, a pátria e o nacionalismo.

A trajetória reflexiva de Lacoste evidencia, então, alguns pontos. Em primeiro lugar, a essência da crítica político-ideológica: a percepção das relações da geografia, enquanto saber ou disciplina, com o poder, especialmente o estatal. Isto é, com quais interesses se associam os geógrafos ao longo da história, seja com os dos príncipes e comerciantes, na produção de uma representação do espaço por eles demandada, seja especificamente com o Estado-nacional, ao engendrar o nacionalismo e, simultaneamente, ocultar o papel da primeira forma de geografia, do saber geográfico, ou seja, ocultar a prática. Tratava-se, sem dúvida, de uma denúncia essencial para superar a

61 "É sintomático que o termo 'país', que é particularmente ambíguo, tenha suplantado, e em todos os discursos, as noções mais políticas de Estado, nação...” (LACOSTE, 2007, p. 56). 
"carência epistemológica" que caracterizava a ciência geográfica - a percepção da função social do saber produzido. Em segundo lugar, o livro de Lacoste esclarece o desdobramento desta crítica em uma de caráter epistemológico - na identificação e refutação das categorias e conceitos que impedem o conhecimento adequado da realidade. Em suma, o primeiro momento

\begin{abstract}
foi também o da crítica epistemológica. Isto é, o mergulho necessariamente mais profundo até o âmago do trançado epistêmico no qual os discursos nascem e acadêmica e institucionalmente se legitimam.

Tal é o que faz Lacoste, quando adverte que 'o problema ideológico parece estar no cerne do problema epistemológico da geografia', alertando para a necessidade do enfrentamento crítico simultâneo da frente ideológico e epistemológica. /.../.

De forma que a renovação começa com a denúncia ético-finalista de um sabe posto secularmente a serviço do poder e dos poderosos, e daí avança rumo aos seus fundamentos (MOREIRA, 2010, p. 32).
\end{abstract}

Com efeito, da percepção da relação da disciplina geografia com os interesses políticos e econômicos dominantes, segue-se a verificação dos instrumentos categoriais que daí se instituem, em outros termos, a crítica dos conceitos presentes e hegemônicos no discurso geográfico que possibilitam o cumprimento das funções ideológicas correspondentes - como vimos, a ocultação do caráter estratégico do saber geográfico, por via da ocultação de todo problema político, e a construção da consciência nacional. Para tanto, Lacoste identifica a proximidade entre a "geografia universitária" e a "geografia dos liceus"- marcada pela "enumeração relevo-clima-vegetação-população" - na "ocultação de todo problema político. Elas são um saber pelo saber" (LACOSTE, 2007, p. 60). Assim, uma das primeiras dimensões dessa crítica é a verificação de uma "prática universitária que é, cada vez mais, a negação do projeto global”, isto é, da “institucionalização do corte entre 'geografia física' e 'geografia humana' (no nível da separação dos cursos, dos manuais, dos programas do liceu e da 'faculdade', que leva em conta isso como critério de recrutamento dos pesquisadores e professores do ensino superior)" (LACOSTE, 2007, p. 101), numa palavra, a manutenção da "relação de exclusão entre a natureza e a sociedade" (LACOSTE, 2007, p. 100).

O passo à frente desse processo residiria, assim, na crítica epistemológica que permitiria superar a referida fragmentação e, por consequência, a relação de exclusão entre sociedade e natureza, reconhecida a necessidade da problematização de alguns conceitos e aspectos metodológicos (e seus compromissos) das pesquisas levadas a cabo pelos geógrafos. Temos, em tom de acusação, a afirmação de que "a maior parte dos geógrafos teoriza o menos possível" (LACOSTE, 2007, p. 95) e, mesmo, a percepção da 
"sua pequena preocupação com problemas teóricos, mesmo os mais fundamentais, que deveriam abordar todas as ciências e há muito tempo" (LACOSTE, 2007, p. 96).

Segue-se, então, a explicitação da "colocação de um poderoso conceito-obstáculo: a região-personagem". É conhecido o essencial da crítica de Lacoste à geografia regional francesa, na feição consagrada a partir de La Blache, responsável por introduzir "a ideia das descrições regionais aprofundadas, que são consideradas a forma, a mais fina, do pensamento geográfico" (LACOSTE, 2007, p. 96):

\begin{abstract}
Ele mostra como as paisagens de uma 'região' são o resultado da superposição ao longo da história, das influências humanas e dos dados naturais. Mas em suas descrições, Vidal dá maior destaque para as permanências, a tudo aquilo que é herança duradoura dos fenômenos naturais ou de evoluções históricas antigas (LACOSTE, 2007, p. 96).
\end{abstract}

Ainda que recentemente coloque-se em discussão o privilégio aos dados naturais na geografia de La Blache ${ }^{62}$, é evidente que tal aspecto é largamente privilegiado e predominante no âmbito da disciplina escolar ${ }^{63}$, em especial a partir do momento em que “a geografia regional é imposta como a 'geografia por excelência': não associaria a ela, estreitamente, a um só tempo, a 'geografia física' e a 'geografia humana'?” (LACOSTE, 2007, p. 61). Em resumo, este demarcado naturalismo, ao invés de realizar a "síntese" proposta, de configurar o "projeto global" aparece como o modo de transmitir "a impressão de que essa divisão da paisagem sempre existiu" (LACOSTE, 2007, p. 61) e ocultar todo "problema político", toda questão referente aos problemas sociais. Sem a problematização dos fundamentos de seu pensamento, sem a "polêmica epistemológica", os geógrafos terminam por não perceber o caráter social de seu "objeto", a região:

Enquanto seria politicamente mais sadio e mais eficaz considerar a região como uma forma espacial de organização política (etimologicamente, região vem regere, isto é, dominar, reger), os geógrafos acreditam na ideia de que a região é um dado quase eterno, produto da geologia e da história. Os geógrafos, de algum modo, acabaram por naturalizar a ideia de região (LACOSTE, 2007, p. 65-6).

Assim, a abordagem fragmentária da realidade na "Geografia dos Professores", a enumeração dos aspectos referentes aos "dados” físicos e humanos, com o claro privilégio dos primeiros, isto é, a naturalização da realidade são resultado, em Lacoste, da necessidade de expurgar os problemas políticos e sociais do discurso geográfico. Este

\footnotetext{
62 ROBIC; OZOUF-MARIGNIER (2013, p. 109), por exemplo, destacam a "transição entre o recorte naturalista e o recorte político-econômico", na obra do geógrafo francês.

${ }^{63}$ De fato, mesmo Lacoste sublinhava que "a corporação dos geógrafos universitários só reteve um aspecto de seu pensamento" (LACOSTE, 2007, p. 60). Para o caso da geografia brasileira, vale atentar para o naturalismo da divisão regional proposta por Delgado de Carvalho, de forte inspiração na geografia francesa.
} 
ponto merece destaque, em nosso trabalho, pois, enfim, Lacoste resvala em nosso tema central: a concepção de homem. Com efeito, se o objetivo é ocultar todo problema político e negar a prática, o conceito de homem adequado a tal discurso é um homem passivo, tão somente "habitante":

Vidal de La Blache instala (com que estilo!) sua concepção do 'homemhabitante' e essa expulsa para fora dos limites da reflexão geográfica o homem nas suas relações sociais, e com mais forte razão ainda, nas relações de produção. Além do mais, o 'homem vidaliano' não habita as cidades, ele mora sobretudo no campo, ele é sobretudo o habitante de paisagens que seus ancestrais longínquos modelaram e organizaram (LACOSTE, 2007, p. 66).

Trata-se, ainda que de passagem, a primeira vez que identificamos que a questão do homem é abordada no processo de crítica. Sem destacar, como vimos fazendo, o viés epistemológico da crítica que então se realiza, não é possível efetivamente compreender suas características básicas - um elemento componente de um discurso mistificador.

E mesmo a abordagem regional termina por constituir um obstáculo ao conhecimento real, em suma, trata-se de "um subterfúgio particularmente eficaz, pois ele impede de apreender eficazmente as características espaciais dos diferentes fenômenos econômicos, sociais e políticos. De fato, cada um deles tem uma configuração geográfica particular que não corresponde à da "região"' (LACOSTE, 2007, p. 62). E mais, além de consagrar "um modo de ver as coisas", a "região-personalidade, organismo coletivo ou mininação da região-personagem histórica, forneceu a garantia, a própria base, de todos os geografismos ${ }^{64}$ que proliferam no discurso político" (LACOSTE, 2007, p. 65) e, por sua vez, consolidam a concepção do homem-habitante, isto é, um homem que não é ativo e produtor, na medida em que "evidentemente esses geografismos designam os homens que vivem nessas cidades e nessas regiões".

Como já destacamos, não nos cabe buscar uma completa caracterização do movimento de renovação e, portanto, nem de seus textos referenciais. Ao contrário, buscamos identificar as principais características da crítica então desenvolvida - no que vai se demarcando seu caráter político-ideológico, desdobrando-se em uma crítica epistemológica - em sua relação com o tema de análise. Nesse sentido, os textos de Lacoste permitiram evidenciar exatamente esses nexos. Como a crítica das funções políticas e ideológicas do discurso geográfico, em suas diversas manifestações, conduz à

\footnotetext{
64 “Por 'geografismos' eu entendo as metáforas que transformam em forças políticas, em atores ou heróis da história, porções do espaço terrestre ou, mais exatamente, o nomes dados (pelos geógrafos) a territórios mais ou menos extensos" (LACOSTE, 2007, p. 65).
} 
crítica de suas categorias e conceitos centrais. Emerge, daí, a noção de "homemhabitante" que, no entanto, não é desdobrada na sequência da argumentação.

Interessante é perceber que, em certa medida, a obra-manifesto de Milton Santos apresenta trajeto e conteúdo análogos. Embora reivindicando uma explícita orientação ontológica ${ }^{65}$, em especial em sua primeira parte (“A crítica da geografia"), contém e aprofunda exatamente a crítica aos procedimentos metodológicos da ciência geográfica, após o apontamento de que, efetivamente "a geografia oficial, foi ‘desde os seus começos' mais uma ideologia que uma filosofia e isso não se deu apenas na Alemanha mas um pouco pelo mundo inteiro" (SANTOS, 1980, p. 13). Por ideologia, especificamente, se entende sua vinculação com os interesses capitalistas quando de sua implantação e expansão: "a ideologia engendrada pelo capitalismo quando da sua implantação tinha que ser adequada às suas necessidades de expansão nos países centrais e na periferia" (SANTOS, 1980, p. 13). Isto é,

\begin{abstract}
Nascida tardiamente como ciência oficial, a geografia teve dificuldades para se desligar, desde o berço, dos grandes interesses. Estes acabaram carregandoa consigo. Uma das grandes metas conceituais da geografia foi justamente, de um lado, esconder o papel do Estado bem como o das classes, na organização da sociedade e do espaço. A justificativa da obra colonial foi um outro aspecto do mesmo programa (SANTOS, 1980, p. 14).
\end{abstract}

Mais uma vez, assim, identifica-se o caráter ideológico a partir da verificação da relação da disciplina com interesses sociais extra-científicos, nesse caso, enquanto mistificação na forma da ocultação do papel do Estado e das classes, ou na justificação da expansão colonial. "O ímpeto dado à colonização e o papel nela representado por nossa disciplina teria sido um fator de seu desenvolvimento" (SANTOS, 1980, p. 15).

A relação dessa crítica política com a epistemológica é evidenciada no texto. Com efeito, "a utilização da geografia como instrumento de conquista colonial" (SANTOS, 1980, p. 14), é perceptível na exaltação direta da obra colonial, em geógrafos importantes como Mackinder e La Blache, mas "as noções de determinismo, de região, de gênero de vida, de áreas culturais, aparentemente inocentes e disparatadas, seguem todas a mesma direção" (SANTOS, 1980, p. 16).

\footnotetext{
65 "Se a geografia não foi capaz de ultrapassar esta deficiência [a construção de um conjunto de proposições estruturantes de um sistema comum e entrelaçada por uma lógica interna], é porque esteve sempre muito mais preocupada com uma discussão narcísea em torno da geografia como disciplina ao invés de preocuparse com a geografia como objeto. Sempre, e ainda hoje, se discute muito mais sobre a geografia do que sobre o espaço, que é o objeto da ciência geográfica" (SANTOS, 1980, p. 2)
} 
Segue-se, nos tópicos seguintes, um conjunto de considerações pertinentes em torno "desses numerosos paradigmas que orientaram a geografia humana moderna" (SANTOS, 1980, p. 19), que podem ser aproximadas, inclusive, das propostas por Lacoste. Por exemplo, no que se refere à noção de "área cultural" ${ }^{66}$, Milton Santos destaca que este modo de ver a Terra, enquanto um "conjunto de formas específicas de utilização do território - de áreas culturais - resultado do trabalho de sociedades diferentes com base em sua diversidade cultural" (SANTOS, 1980, p. 18), que

\begin{abstract}
esta ótica corre o risco de falhar, pois ela leva a trabalhar sobre quadros mais ou menos congelados, as paisagens, enquanto a sociedade está sempre pronta a lhes oferecer novas funções, novos significados e novos valores, ao mesmo tempo em que o quadro de ação pode continuar imutável ou apenas mudar um pouco (SANTOS, 1980, p. 18).
\end{abstract}

Ou seja, a perspectiva é a mesma de Lacoste: a associação da geografia com determinados interesses a direciona a um conjunto de categorias que terminam por obstaculizar o acesso à própria realidade. Nisso consiste o caráter ideológico do discurso, e sua relação com a crítica epistemológica. Em suma, temos a compreensão da ideologia como uma espécie de "falsa consciência" que obscurece o conhecimento, como explicitamente, afirma mais adiante, ao reconhecer que "toda verdadeira teoria é sinônimo de teoria revolucionária" na medida em que expressa a realidade, isto é, "tem de se adequar às condições atuais do mundo atual e representar uma relação entre o novo, e seu significado original e as coisas velhas com seu novo significado" (SANTOS, 1980, p. 156), enquanto, por sua vez, "uma ideologia não é propriamente uma teoria mas o seu oposto" (SANTOS, 1980, p. 157), razão pela qual não concede à geografia quantitativa a condição de teoria, ou mesmo paradigma, já que "ela não buscava interpretar os fatos tais como eles eram mas, ao contrário, seu objetivo era o de contribuir à geração de fatos segundo uma certa ideologia" (SANTOS, 1980, p. 157).

"Ideológico", assim, aparece como algo simplesmente inexistente. No caso da geografia, por exemplo, "sua base de ensino e de pesquisa é a história dos historiadores, a natureza 'natural' e a economia neoclássica, todas as três tendo substituído o espaço real, o das sociedades em seu devir, por qualquer coisa de estático ou simplesmente de não existente, de ideológico" (SANTOS, 1980, p. 91). De modo que "a geografia pode

\footnotetext{
${ }^{66}$ Noção mais presente na geografia estadunidense a partir das contribuições de Carl Sauer. Vale destacar que o próprio geógrafo brasileiro admite que "as fundações da escola de Sauer se aproximam das de Vidal de La Blache e seus alunos. A geografia cultural é também possibilista e a noção de gênero de vida, se associada àquela de região (segundo Vidal de La Blache), não está distante da ideia de área cultural" (SANTOS, 1980, p. 20).
} 
ser definida, desde a sua fundação, mas sobretudo depois da Segunda Guerra Mundial, por um conjunto de postulados que, ao invés de ajudar a descoberta do real, contribuía para escondê-lo" (SANTOS, 1980, p. 93). Em suma, a questão é posta explicitamente como de âmbito gnosiológico, no sentido de acentuar os compromissos políticos da teoria: "a tendência de uma ciência comprometida com interesses de grupos a empanar uma visão correta da realidade, equivaleu a ocultar a evolução da história humana" (SANTOS, 1980, p. 93).

E é nessa perspectiva que aparece a questão das relações de exclusão entre sociedade e natureza, ao comentar o surgimento da "ecologia humana", que

poderia vir em auxílio de uma geografia já desacreditada e ajudá-la a levantarse com um novo paradigma. Ao menos, porém, numa primeira fase, a ecologia destinada a fornecer um quadro conceitual mais elaborado, não se afastou da antiga orientação. Esta nova disciplina ocupava-se da natureza e do homem como se fossem categorias opostas. A 'natureza' que fazia parte do sistema ecológico, era uma natureza 'primária' e não uma natureza socializada; uma natureza sem história humana. O homem atuava sobre o meio como se estivesse separado dele e não como um dos seus elementos (SANTOS, 1980, p. 21).

Ao contrário, com efeito, a "ecologia humana" acabou por aguçar os "equívocos da geografia regional e perpetuou uma concepção dualista", na qual se demarca, vale frisar, uma forma de conceber o homem como apartado do meio, e não sua parte integrante, enquanto a natureza é abordada em sua "forma primária", não socializada, isto é, sem a intervenção humana. Evidenciando a noção de "relações de exclusão" "67, utilizada por Lacoste.

Esta exclusão do homem, na consideração do espaço, é confirmada na trajetória da disciplina, em especial com a "geografia quantitativa”, por Milton Santos considerada a "sofisticação do velho lastro positivista da disciplina geográfica, cuja noção de região representou um passo preliminar mas fundamental" (SANTOS, 1980, p. 88). Isto é, enquanto "o estudo da região como entidade autônoma seria o objeto de uma dialética defeituosa entre um homem separado do capital e um em torno não socializado e isto em lugar de uma dialética entre os homens, estudada a partir da dialética própria à sociedade inteira" (SANTOS, 1980, p. 88), no caso da "nova geografia", "o espaço geográfico é

\footnotetext{
${ }^{67}$ Trata-se, com efeito, de uma dimensão central nesse momento de crítica à tradição geográfica. Igualmente Armando Corrêa da Silva, por exemplo, identifica, em obra publicada no mesmo ano de 1978, a fragmentação e a perda da totalidade como elemento essencial da tradição científica da disciplina: "O problema se põe porque nem Humboldt, nem Ritter, nem Ratzel, nem Vidal de La Blache, nem Christaller, nem Elisée Reclus, nem Max. Sorre, nem Pierre George, nem a grande maioria dos geógrafos clássicos e modernos consegue chegar a uma visão do conjunto. O conhecimento Moderno e Contemporâneo relacionado à visão liberal do mundo é fragmentado por definição" (SILVA, 1978, p. 6).
} 
estudado como se ele não fosse o resultado de um processo onde o homem, a produção e o tempo exercem o papel essencial" (SANTOS, 1980, p. 88) e, nesse sentido, "a grande miséria do empiricismo é que ele encobre as relações entre os homens, substituindo-se por relações entre objetos, inclusive os objetos geográficos" (SANTOS, 1980, p. 87) . Mais uma vez, temos o foco na questão da exclusão: o homem é excluído do meio, do espaço, encobrindo-se assim as relações sociais e, de outro lado, "desespacializando" e "desistorializando" o espaço, que passa a ser representado como "um conjunto de fórmulas matemáticas de onde a história - ou seja, o homem - era sistematicamente afastado" (SANTOS, 1980, p. 88).

O importante a destacar, neste trecho da argumentação miltoniana, é o tracejamento das razões de tais operações teóricas, isto é, dos motivos e mecanismos que impedem a visão correta da realidade. Nesse sentido, Santos destaca que "uma das razões fundamentais pelas quais a geografia tem conhecido uma evolução tão lenta e tão decepcionante, que às vezes, somos tentados a penas em involução, é imputável ao peso que as velhas ideias têm dentro desta disciplina" (SANTOS, 1980, p. 83), que, por sua vez, pode ser explicado por questões de ordem político-institucional, ou seja, "ao invés de perseguir um saber novo, preferimos deliciar-nos com a reprodução do saber velho. Isto é possível pelas formas de cooptação que embora diferentes segundo os lugares, terminam oferecendo os mesmos resultados, isto é, a canonização dos modelos" (SANTOS, 1980, p. 84). Em realidade, Milton Santos direciona sua crítica especificamente à estrutura universitária e o correspondente privilégio aos "grandes professores":

O papel dos chefes de cátedra (aqueles a quem os franceses sem malícia chamam 'o patrão'), a maneira como se faz o acesso à profissão de ensinar, as formas de aceitação dos trabalhos, a organização da pesquisa e de sua difusão, tudo isso dá aos chamados grandes professores uma posição de prestígio incontestável que impede de colocar em discussão as suas ideias, mas, ao contrário, induz a reproduzi-las, por mais velhas que sejam (SANTOS, 1980, p. 84).

Como vimos, Milton destaca ainda que especialmente após a Segunda Guerra Mundial, o caráter ideológico da geografia se acentua, e isto porque "tais tendências se agravaram exponencialmente depois de 1945, quando a geografia passou, de maneira mais clara, a estar ao serviço da realização de um projeto imperial” (SANTOS, 1980, p. 85), neste caso, o deslocamento do centro do imperialismo aos Estados Unidos. Emerge, então, uma produção de ideias concentrada neste país, "em grande parte a produção de ideias de encomenda, destinadas a facilitar desígnios comerciais e políticos" (SANTOS, 
1980, p. 85). Enfim, a geografia termina por "perder seu objeto", na inviabilização de seu "imperialismo gnosiológico" original, quando objetivava ser uma ciência de síntese, tendência mais predominante na Europa, e predomínio da tendência pragmática americana, ou seja, por sua ligação mais efetiva e direta com os interesses capitalistas, que impulsionam a fragmentação e especialização, de modo a poder-se falar de um "espaço pulverizado":

A geografia americana, alimentada de pragmatismo, tomando como objeto de estudo pedaços isolados ou aspectos singulares da realidade ao gosto do cliente, acabou por pulverizar o objeto da disciplina e a própria disciplina. A proliferação dos temas a estudar a distanciava cada vez mais da construção de uma síntese à medida que a geografia tornava-se mais utilitária, tornava-se também menos explicativa (SANTOS, 1980, p. 91, grifo meu).

\subsubsection{CONSIDERAÇÕES SOBRE AS "ESCOLAS NACIONAIS”}

Uma das consequências da crítica político-ideológica, de marcado viés epistemológico, conforme caracterizamos, foi o referendo à leitura do pensamento geográfico a partir das chamadas "escolas nacionais", dimensão mais explicitamente presente nos artigos e livros de divulgação que sedimentam e galvanizam o movimento de renovação. Com efeito, em especial desde a publicação de A terra e a evolução humana, de Lucien Febvre ${ }^{68}$, em 1922, consagrou-se, na leitura do pensamento geográfico, a pretensa polarização entre a Geografia Alemã e a Geografia Francesa, enquanto "escolas" encarnadas, respectivamente, no "determinismo" de F. Ratzel e no “possibilismo" de La Blache, expressões concretas (e, de certo modo, diretas e simplistas) dos conflitos sociais, políticos e econômicos que contrapunham os dois países. No caso da Geografia brasileira, dada sua origem institucional vinculada à "missão francesa" e

\footnotetext{
${ }^{68}$ Dentre outros, afirma Luciana de Lima MARTINS (1993, p. 3): "Mas foi com a obra de Lucien Febvre - La Terra et l'Évolution Humaine - que se estigmatizou a pecha de determinista para Ratzel, em contraposição ao possibilismo de Vidal de la Blache, termo cunhado pelo próprio Febvre". Guy MERCIER (2013, p. 138) sintetiza: "Quando se comparava a obra de Paul Vidal de La Blache (1845-1918) com a de Friedrich Ratzel (1844-1904), tinha-se o costume de opor o 'possibilismo' do primeiro ao 'determinismo' do segundo. Tal oposição provém, em larga medida, do comentário partidário de Lucien Febvre (1922) que, para melhor condenar os presumidos erros de Ratzel, caricaturou seu pensamento confinando-o a algumas sentenças lapidares revestidas sob o pejorativo título de 'determinismo"'. Por fim, pode-se remeter também a Guilherme RIBEIRO (2009) que destaca os impactos negativos na própria leitura de La Blache, a partir da caracterização do historiador francês.
} 
apesar de certa influência de origem germânica (como Leo Waibel, por exemplo, ou mesmo presente em Deffontaines), postando-se claramente na defesa do "possibilismo", vê-se predominar essa leitura na síntese e avaliação da ciência geográfica ${ }^{69}$.

Na obra de Milton Santos, comentada acima, encontramos já a refutação dessa leitura, enquanto resultante de uma estrutura universitária calcada nos "grandes professores", indicando seus efeitos deletérios:

o vício tornou-se tão acentuado que, às vezes, esse trabalho de glorificação do
mestre já consagrado levou seja à deturpação das suas próprias intenções
originais, seja à deturpação das ideias daqueles que, fora da sua influência,
tiveram ideias diferentes. /.../. Do segundo caso, o exemplo melhor é o de
Ratzel, cuja obra, elogiada por Vidal de La Blache, foi, todavia, repudiada
depois pelos alunos deste, a a serviço de preconceitos ligados à pretensa
existência de escolas nacionais (SANTOS, 1980, p. 85).

Porém, no bojo da crítica ao que se convencionou designar por "Geografia Tradicional" encontram-se certas permanências dessa leitura - agora incorporando tons críticos à Escola Francesa e, especialmente, destacando a vinculação das escolas com os interesses imperialistas específicos. Mesmo que igualmente se encontrem posições que apontam mediações e problemas nessa leitura e, como veremos, mais recentemente a msma venha sendo constantemente criticada e refutada, o entendimento mais global ainda mantém a referência às escolas, bem como a republicação de alguns textos atuem na sua manutenção ainda atualmente.

Moraes (2002, p. 64), por exemplo, em sua conhecida obra de divulgação: “a Geografia de Ratzel legitimava a ação imperialista do Estado bismarckiano. Era mister, para a França, combatê-la. O pensamento geográfico francês nasceu com esta tarefa". Sobressaindo, nesse combate, "uma terceira crítica de Vidal à Antropogeografia /.../ [que] atacou a concepção fatalista e mecanicista da relação entre os homens e a natureza" (MORAES, 2002, p. 67). De modo que, enfim, referenda-se Lucien Febvre: "a natureza passou a ser vista como possibilidades para a ação humana; daí o nome de Possibilismo" (MORAES, 2002, p. 68).

Ruy Moreira, em outro texto de divulgação do mesmo período, explicita uma abordagem acerca da obra de Ratzel, inclusive, menos mediada ${ }^{70}$ : “Assim, dirá Ratzel, o homem, em todos os seus planos de existência, tanto mental como civilizatória, é o que

\footnotetext{
${ }^{69} \mathrm{Cf}$, por exemplo, Nilo BERNARDES (1982).

${ }^{70}$ Moraes, no texto citado, afirmava, de início que as teses deterministas teriam sido acentuadas e radicalizadas apenas pelos continuadores de Ratzel, embora, nas passagens citadas acima, contrapõe, diretamente, La Blache à Antropogeografia de Ratzel.
} 
determina seu meio natural (teoria do determinismo geográfico)" (MOREIRA, 1983, p. 32). E a problematização da Geografia francesa é semelhante, toda a "escola francesa" simplesmente como esfera do combate ideológico contra a Alemanha: "Da crítica de Ratzel sairá o elemento-chave da geografia da 'escola francesa': a teoria do possibilismo. Seu formulador: Paul Vidal de La Blache” (MOREIRA, 1983, p. 35).

Manuel Correia de Andrade (1992, p. 66) explicita o vínculo essencial do entendimento de ideologia como um conhecimento apropriado por interesses extracientíficos e a consolidação da "leitura" das escolas, ao afirmar, de um lado, que a geográfica clássica "teve grande importância porque atendeu aos desafios que a burguesia, como classe dominante, encontrou na sua luta pela exploração dos recursos e dos homens na superfície da Terra" e, de outro, ao reconhecer que "como os meios, conforme a situação econômica de cada país e os deságios que os governos, comprometidos com as classes dominantes, encontravam para fazer o seu próprio 'desenvolvimento', fossem diversos, ela se fragmentou em escolas nacionais ou até regionais" (ANDRADE, 1992, p. 66). Estas escolas, assim, teriam a intenção clara de atender os interesses específicos das classes dominantes, através de seus Estados, em seus termos:

elas se orientavam para estudos de maior interesse para o próprio país e procuravam soluções e orientação que justificassem a ação do mesmo. /.../. Tinham essas escolas, como não poderia deixar de ser, um sentido profundamente nacionalista, estavam comprometidas com os governos de que dependiam e a que serviam (ANDRADE, 1992, p. 67).

Carlos Walter Porto Gonçalves e Nilce Moreira de Azevedo, em texto de 1982, expressam igual entendimento, ao remeter a Heródoto e à noção de região, conforme lembrado por Lacoste do latim regere, e reconhecer que "o pensamento geográfico e o fenômeno do imperialismo têm estado tradicionalmente interligados" (GONÇALVES; AZEVEDO, 1982, p. 24) e que "no imperialismo moderno, o discurso geográfico aparece mais uma vez como um justificador" (GONÇALVES; AZEVEDO, 1982, p. 24), de que a "teoria ratzeliana do espaço vital" corresponde a um "bom exemplo", bem como o fato de que "o determinismo naturalista adquire um significado novo, como justificativa de uma divisão internacional do trabalho que se presente objetiva, uma vez que imposta por condições naturais" (GONÇALVES; AZEVEDO, 1982, p. 24).

Do mesmo modo, inclusive, a "escola francesa", a "pseudo-crítica Lablacheana ao determinismo geográfico" (GONÇALVES; AZEVEDO, 1982, p. 25), é apontada como produtora de um discurso, in limine, justificador da expansão imperialista: 
Ao creditar à capacidade humana em geral a possibilidade de criar, não situando historicamente este atributo, o Possibilismo terminará por entendê-lo como inerente a uma "essência humana", fundando-o, inevitavelmente, em razões biológicas e naturais. De onde provém esta capacidade humana? Estranho caminho este o dos possibilistas que acaba por se encontrar com o determinismo... na natureza. Isto porque, se estas capacidades humanas não são engendradas historicamente, só podem advir da natureza ou de Deus (GONÇALVES; AZEVEDO, 1982, p. 25).

Assim, ainda que, e se trata efetivamente de um avanço, busque-se superar a "armadilha ideológica" do "grande dilema entre ser determinista ou possibilista", acentuando-se a proximidade real entre os chamados "determinismo" e "possibilismo", tal se faz ao reconhecer que este é igualmente "ideológico", isto é, pauta-se na necessidade de justificar a expansão imperialista: "deste modo, o possibilismo constitui, de fato, mais uma ideologia naturalizante, com forte tendência a cair numa biologia de conotação racista" (GONÇALVES; AZEVEDO, 1982, p. 25).

Vale anotar nesse momento, não questionamos, de completo, o conteúdo desta crítica. De fato, a geografia dita "possibilista", como veremos mais adiante, parece conter inegáveis determinações naturalizantes. O que merece ser destacado, porém, é a afirmação onipresente de que tais características advêm da necessidade de implantar, inculcar um discurso a fim de justificar interesses exteriores à lógica científica. Enfim, trata-se de um exemplo particular do entendimento da ideologia como "falsa consciência".

É recente o processo de releitura e reavaliação do pensamento geográfico identificando novas e efetivas polarizações, como por exemplo da Geografia positivista de Ratzel e La Blache com a neokantiana de A. Hettner e, no âmbito mais geral do que pode ser conhecido como o pensamento geográfico - "a geografia em pensamento" - a contraposição mais efetiva com o próprio marxismo.

É do mesmo Ruy Moreira, com efeito, a utilização da noção de matriz de pensamento, que busca esclarecer a "forma própria de pensamento" de cada geógrafo, ressaltando sua individualidade e episteme. Reconhece-se, então, que "o defeito da [tradição da] escola é a supressão dos seus pensadores: há o chefe-de-escola e seus discípulos. Mesmo quando estes são pensadores originais, são seus continuadores" (MOREIRA, 2008, p. 37). Reconhecendo tanto os extremos de sua posição anterior - em que "a tradição da escola vem da ideia da associação e colagem da Geografia com os discursos do Estado e do imperialismo" (MOREIRA, 2008, p. 38) - como o fato de que "Vidal de La Blache e Friedrich Ratzel são as principais vítimas desse tipo de leitura" 
(MOREIRA, 2008, p. 38) $)^{71}$. Nesse sentido, torna-se fundamental demarcar que "nem Vidal de La Blache é possibilista e nem Ratzel é determinista, e tanto em um quanto em outro a história aparece como possibilidade (não como possibilismo), em ambos a possibilidade histórica aparece no âmbito das relações do homem com o meio, mas não para se expressar em um como isto e em outro como aquilo" (MOREIRA, 2008, p. 42). É quando, então, verdadeiras distinções vêm à tona: "Se há uma substância que distinga a Geografia dos alemães da dos franceses, esta é a vinculação da Geografia alemã com o naturalismo, na mesma medida que a dos franceses tem com o historicismo" (MOREIRA, 2008, p. 41).

Aqui, no entanto, devemos apontar para a existência de lineamentos, no seio mesmo da renovação crítica da geografia, a explicitar a possibilidade de uma crítica mais mediada do discurso geográfico, a partir do reconhecimento de seus fundamentos ontológicos.

\title{
1.3. LINEAMENTOS DE UMA CRÍTICA ONTOLÓGICA
}

Vejamos, nesse sentido, Massimo Quaini que nos anos de 1974 e 1983 lança duas obras associadas ${ }^{72}$ objetivando, simultaneamente, a crítica da ciência geográfica estabelecida e a extração dos princípios fundamentais da geografia presente na obra de Marx, isto é,

\begin{abstract}
os balões de ensaio necessários para uma geografia humana marxista (ou também apenas moderna), não podem deixar de ser preparados por uma consciência epistemológica renovada em relação à especialização ou setor científico no qual o geógrafo humano trabalha, e que tal consciência se coloca, antes de mais nada, no terreno histórico e em primeiro lugar no terreno de uma história crítica da nossa disciplina (QUAINI, 1992, p. 9).
\end{abstract}

Nesse sentido, enquanto seu primeiro livro, Marxismo e Geografia dedica-se especialmente ao estudo do pensamento de Marx e sua relação com a geografia (enquanto ciência e dimensão da realidade) ${ }^{73}$ - podemos destacar os dois primeiros capítulos

\footnotetext{
71 Também Guy MERCIER (2013, p. 138) afirma que "de tanto querer pôr os dois geógrafos um contra o outro, Febvre não fez justiça nem a um e nem a outro".

${ }^{72} \mathrm{O}$ próprio Quaini ressalta, acerca de $A$ construção da geografia humana, que "o projeto deste ensaio nasceu no decorrer da pesquisa para o Marxismo e Geografia e a ela quer se ligar, como momento retrospectivo, talvez mais 'tradicional' mas não menos necessário" (QUAINI, 1992, p. 9).

${ }^{73} \mathrm{E}$ com o qual estabeleceremos um diálogo mais específico no andamento deste trabalho.
} 
(respectivamente, "A crise da geografia" e "Filosofia e geografia") no tocante à crítica da ciência -, A construção da geografia humana é voltado especificamente a este intento. Ainda que nossa atenção, nesse momento, se direcione a aspectos mais específicos destes textos, cremos ser válida sua discussão na medida em que consideremos a pontuação crítica de Moreira:

\begin{abstract}
É irônica, por exemplo, a pouca importância que os próprios geógrafos de formação marxista emprestaram a Marxismo e geografia. Texto efetivamente referenciado como uma obra marxista, esse livro teve circulação menos que a devida entre os próprios marxistas. E a desatenção é mais gritante e patente com a Construção da geografia humana, livro escrito por Quaini utilizando material recolhido para a escrita do primeiro, no qual tece a mais estimulante releitura da trajetória histórica do pensamento geográfico do período de um ponto de vista marxista, pondo suas origens modernas no Iluminismo. Em Kant, pois, e não em Humboldt-Ritter, uma interpretação conhecida desde as pesquisas de Richard Hartshorne. Quem nele se referenciou ou quem o leu? (MOREIRA, 2010, p. 30).
\end{abstract}

Com efeito, quanto à primeira obra, nos momentos em que se destaca a crítica à geografia, temos a explicitação de um elemento central do pensamento geográfico: a naturalização e eternização das relações sociais históricas (no caso, capitalistas). Após justificar o embasamento da nova teoria geográfica no marxismo, na medida em que em Marx temos tanto a possibilidade da crítica da geografia (a partir da crítica realizada à economia política, enquanto uma "representação caótica do conjunto da realidade") como a "mais rigorosa instrumentalização lógica de que se sente necessidade para fundamentar uma ciência do território que não seja nem caótica erudição nem saber apologético" (QUAINI, 1979, p. 14), Quaini identifica que, como a economia política criticada por Marx, também a geografia corresponde não só a "uma representação caótica do conjunto da realidade", mas "comporta desde a origem o uso de abstrações indeterminadas ou de 'determinações (conceituais) muito simples [...] diluídas em meras tautologias' e portanto conduz a uma substancial infecundidade científica" (QUAINI, 1979, p. 14). Para, então, alertar: "mas atenção: através de tais procedimentos tautológicos, passa-se à eternização dos modos de produção historicamente determinados, isto é, passa-se à apologia dos processos econômicos e territoriais do modo de produção capitalista" (QUAINI, 1979, p. 15, grifo do autor). Quaini fornece alguns exemplos tirados de um manual de geografia geral a respeito, especificamente, da geografia da produção, identificando que "raciocínios absolutamente tautológicos do tipo: a indústria se desenvolve tanto mais facilmente quanto existirem suas condições", logo introduz "de modo totalmente acrítica, os capitais e os capitalistas" (QUAINI, 1979, p. 15) como condições gerais de produção. O mesmo procedimento constata Quaini na geografia política: “o processo idêntico pelo 
qual nas leis geográficas, concebidas como leis da natureza, eternas e independentes da história, são interpoladas, de forma totalmente sub-reptícia, as relações sociais burguesas" (QUAINI, 1979, p. 15). De modo que se esclarece a infecundidade científica na medida em que, "se quisermos nos colocar num terreno crítico-científico", a verdadeira tarefa é a explicitação da "diferença do elemento comum", isto é, não apenas identificar os elementos em comum ao longo dos diversos momentos da história, mas o específico.

Ainda que explicitando de forma mais clara a operacionalização através da qual o discurso geográfico converte-se num saber estritamente apologético, por enquanto, em Marxismo e geografia, a linha geral de reflexão é a mesma da identificada nas outras obras e artigos: as características deformadas e deformadoras da geografia devem-se a fatores de ordem "ideológica", mais diretamente, políticas, enquanto justificação, através de uma "falsa consciência", de interesses sociais e políticos. Como transparece na interessante recuperação da geografia presente na filosofia hegeliana:

\footnotetext{
Parece portanto evidente o resultado 'geográfico' da filosofia da história de Hegel: a dialética do espírito do mundo toma as roupagens de uma história nitidamente etnocêntrica justificada sobre uma base geográfica e caracterizada por um processo histórico unidirecional em que as diversas fases históricas ou formações histórico-naturais são os momentos necessários da progressiva realização do espírito, que considera concluída como sociedade germano-cristã ou burguesa (QUAINI, 1979, p. 33).
}

No entanto, certa especificidade da posição de Quaini já se percebe na medida em que acentua, mais do que a ligação com o imperialismo, a vinculação com a naturalização da ordem capitalista. Tal especificidade, nos parece, é desdobrada e ampliada em sua obra posterior, ao abordar "um esquema de periodização da geografia humana positivista". O essencial da crítica, vale destacar, permanece o mesmo (o que nos parece adequado, frisese): "a geografia vê, sub specie aeternitatis, problemas histórica e socialmente determinados e lhes fornece um intransponível fundamento natural" (QUAINI, 1992, p. 44), razão pela qual terá importante e reforçado papel ideológico, no sentido, ainda, de expurgar a reflexão política e ocultar o papel das classes e grupos dominantes:

Dada a evidente funcionalidade da concepção determinista, compreende-se também, facilmente, as razões de sua persistência no senso comum, na ideologia das classes dirigentes e também o nível 'científico'. A geografia determinista, mesmo a nível universitário, continuou a desempenhar um papel ideológico preciso, que consiste em evitar a reflexão política sobre os desequilíbrios territoriais e em mascarar as escolhas de política territorial efetivas dos grupos dominantes (QUAINI, 1992, p. 44).

Mais uma vez, o ponto de partida é o mesmo de, por exemplo, enquanto referências principais, Lacoste e Milton Santos. Com efeito, não é nosso propósito negar 
essa dimensão, mas acreditamos, no entanto, que na sequência Quaini introduz um elemento novo, ao afirmar que "a mentalidade positivista deve ser considerada a Weltanschauung mais característica da época capitalista e das classes médias contemporâneas" (QUAINI, 1992, p. 44). Ou seja, mais do que uma falsa consciência imposta de fora, a geografia positivista aparece como a expressão específica de um modo de ver enraizada em um modo de viver dos homens, razão pela qual pode-se entender a ampla divulgação e aceita das ideias deterministas e ambientalistas: é, principalmente, porque a visão determinista ou ambientalista é perfeitamente funcional à ideologia e à concepção do mundo e da sociedade que dominam na época capitalista" (QUAINI, 1992, p. 45).

E tais ideias dominam na sociedade capitalista não simplesmente por sua imposição através de "aparelhos ideológicos", mas porque, é possível depreender de Quaini, são as ideias da classe dominante, isto é, é o modo como a classe dominante, efetivamente, concebe o mundo, é sua mentalidade. Em seus termos: "a relação entre a geografia determinista e o capitalismo é até mais orgânica do que nos dizem os críticos da ideologia positivista. No fundo, o determinismo geográfico reflete de forma mistificada a condição de alienação do território em relação ao homem" (QUAINI, 1992, p. 46, grifo do autor). Grifemos o essencial: mais do que a imposição de uma falsa consciência, de uma falsa concepção, através de mediações políticas, a geografia positivista corresponde à expressão, ainda que mistificada, da condição de alienação do homem na sociedade capitalista. Vale reter a continuidade da citação, inclusive por explicar o que entende por território e alienação: "Com o sistema capitalista, o território, isto é, o conjunto das condições materiais do trabalho (a cidade, o campo etc.) torna-se 'outra coisa' em relação ao homem, tornando-se uma força autônoma que se contrapõe e domina o homem, embora sendo uma criação do trabalho humano" (QUAINI, 1992, p. 46). Notaremos, no próximo capítulo, a proximidade da concepção de alienação exposta, como a separação e autonomização das forças dos homens em relação aos mesmos, com a explicitada por Marx. De todo modo, é o próprio Quaini que, na sequência do argumento, explicita, também nesse ponto central e específico, seu ponto de partida na posição marxiana, e fiquemos com a passagem completa:

Portanto, para a 'melhor' geografia determinista e descritiva pode-se, em parte, repetir aquilo que Marx observava a propósito de Hegel: 'não se deve recriminar Hegel pelo fato de descrever o Estado moderno como ele é, mas pelo fato de que ele faz passar aquilo que é como sendo a essência do Estado'. Do mesmo modo não se deve recriminar o determinismo pelo fato de descrever 
a submissão do homem à 'natureza', mas porque, não vendo a especificidade histórica e social desta dominação, a mistifica, interpretando-a como natural e biológica quando, na verdade, é somente social e historicamente determinada (QUAINI, 1992, p. 47).

Para o encaminhamento de nossa discussão, vale reter um último aspecto da obra de Quaini: embora mantenha, no geral, a terminologia da leitura consolidada das escolas, o "determinismo" e o "possibilismo", no quadro geral de sua reflexão, supera a pretensa oposição entre ambas. Em primeiro lugar ao afirmar que, quanto ao possibilismo e a escola geográfica francesa, “devemos precisar desde logo que ela não nasce, como muitas vezes foi imaginado, da cabeça de Vidal de La Blache, como uma Minerva armada contra o ambientalismo ou determinismo geográfico da geografia antrópica de Ratzel" (QUAINI, 1992, p. 47). Distintamente, a escola geográfica francesa instaura-se no seio do ecologismo positivista, do qual incorpora noções fundamentais, como as de ambiente ou milieu. Assim, mais do que qualquer tipo de oposição e contraposição entre as escolas alemã e francesa, Quaini identifica sua proximidade essencial - a naturalização ${ }^{74}$-, o que, ainda assim, não o impede de verificar a especificidade desta última, que "se distancia do determinismo, demonstrando principalmente a complexidade das relações homemambiente na escola regional" (QUAINI, 1992, p. 48). No entanto, Quaini grifa o "risco teórico" presente na abordagem possibilista - que sem a definição explícita de homem e de trabalho não é capaz de estruturar um discurso efetivamente explicativo. Isto é,

diante da desorientação e das dificuldades produzidas por uma abordagem totalmente possibilista, não é raro, portanto, que a hierarquia indispensável dos possíveis fatores se reconstitua em moldes nitidamente deterministas ou que o problema se contorne através de uma geografia meramente descritiva, nada ou quase nada responsável diante dos problemas sociais (QUAINI, 1992, p. 49).

Parece-nos, enfim, que temos aqui uma posição distante no tocante à concepção de ideologia - não apenas como a imposição de uma falsa consciência, mas como a expressão mistificada, porque naturalizada, de uma condição real. A riqueza dessa passagem não é desdobrada pelo próprio Quaini em outros momentos do texto. E não encontramos, confirmando a advertência de Moreira, outras referências e debates em torno da questão.

E é exatamente em alguns trabalhos de Ruy Moreira que é possível verificar certo desdobramento no sentido da crítica da concepção de homem na ciência geográfica, a

\footnotetext{
74 “O projeto de Vidal, de uma geografia como ciência das relações do homem com o ambiente natural, em que o homem e a sociedade são ainda considerados dentro da natureza mais do que a natureza na sociedade e na produção (da vida material do homem) e que, por esta razão, não supera os limites de uma ciência ecológica para fundar uma ciência social e histórica, exprime portanto, desde o início, as contradições nas quais nasce a geografia humana moderna" (QUAINI, 1992, p. 48).
} 
partir da constatação de seu elo orgânico com a sociabilidade capitalista. Seguimos, então, ao surgimento da noção de homem atópico no seio da crítica (ainda de caráter políticoideológico, como há ser) desenvolvida por Ruy Moreira. Tal noção emerge de maneira mais explícita na obra $O$ discurso do avesso, publicada em 1988, e voltada a "uma reflexão crítica sobre um saber escolar cujo papel ideológico não tem sido avaliado pelos que dele fazem sua prática cotidiana, os seus professores, e muito menos de parte de cada um nós, seres viventes de uma sociedade corporativa" (MOREIRA, 1988, p. 9) e que apresenta como objetivo explícito a "crítica da epistemologia da geografia que se ensina. Ou seja, de sua crítico ideológico-epistemológico" (MOREIRA, 1988, p. 9-10). Nesse sentido, Moreira inicia o livro por um capítulo intitulado "Como pensamos" e por uma acusação de saída: em qualquer uma das formas de definição do discurso geográfico (enquanto estudo da relação homem-meio, da paisagem ou da organização do espaço pelo homem), "os conceitos empregados são 'soltos’ e descosidos” (MOREIRA, 1988, p. 10). E mais: "em qualquer uma dessas definições o conceito de natureza é invariavelmente o mesmo, no fundo, o mesmo acontecendo com o conceito de homem" (MOREIRA, 1988, p. 10).

Ruy Moreira retoma, assim, os termos gerais da crítica à fragmentação do discurso geográfico e a "falência do projeto unitário". Em outros termos, retoma a recíproca exclusão entre homem e natureza ao discutir a "concepção de relação homem-meio que temos levado à sociedade através da geografia que se ensina":

\footnotetext{
Se bem refletirmos sobre este discurso, para ele a natureza é todo o mundo natural (não inclui o homem) e seu estudo é feito pela Geografia Física. E homem é todo o mundo humano situado fora do mundo da natureza e do mundo da história e seu estudo é feito pela Geografia Humana. É esta concepção de homem atópico o ponto inicial da complicação (MOREIRA, 1988, p. 15).
}

A noção de homem atópico, assim, corresponde à concepção de homem que caracteriza a tradição da ciência geográfica: um homem que "não tem lugar", ou melhor, que está, mas não é sua geografia (no sentido de que essa não é seu produto, não é sua extensão inorgânica) - o espaço ou a paisagem. Neste ponto podemos identificar a relação com a condição de alienação, constatada por Quaini. No discurso geográfico, o homem é um elemento percebido, mas tão somente um elemento presente na paisagem, sem ser a paisagem, ou o espaço, os quais, afinal, não produz. Como afirma o mesmo Moreira, em texto mais recente: "está em relação com a paisagem, o meio e o espaço, mas paradoxalmente não é nenhum deles. Não é paisagem, não é meio e não é espaço, assim 
como não é natureza e não é sociedade. Está em cada quadro, mas embutido, não é” (MOREIRA, 2006, p. 119).

E esta concepção de homem é o ponto inicial da complicação pois fundamenta e inicia a ruptura e o rompimento com a noção de totalidade pela distinção e oposição de suas "partes":

Estas partes, não tem uma mesma origem genética, e surgem como entes individuais distintos e paralelos, mas, por se encontrarem no mundo uma ao lado da outra, no âmbito do conjunto acabam por entrar em relação umas com as outras, e, daí para diante, se influenciam reciprocamente de tal modo ao ponto de cada parte sofrer alterações que lhes podem produzir mudanças, surgindo, assim, a evolução de cada uma e do conjunto (MOREIRA, 1988, p. 16).

De modo que temos, aí, "a origem da dicotomia GF X GH” - "cada 'parte' dá origem a uma ciência ou ramo de uma ciência" - e "uma encruzilhada de problemas":

Além de a Geografia Física e de a Geografia Humana se subdividirem ao infinito, em infindável ramificação que cria um universo heterogêneo de especialidades e especialistas, o lugar da Geografia na fronteira das ciências a faz lidar com um homem que, apesar de viver relações 'dialéticas', é um homem metafísico (MOREIRA, 1988, p. 17).

A referência de definição de "metafísico" é, claramente, a exposta por Lefebvre (1991, p. 50): "por definição, designaremos como 'metafisicas' as doutrinas que isolam e separam o que é dado efetivamente como indissoluvelmente ligado". E, de fato, Ruy Moreira retoma a caracterização do homem atópico, metafísico, nos seguintes termos:

É o homem atópico - não localizado seja na natureza, seja na sociedade - a essência do problema. Quando se busca refletir sobre a relação homem-meio ou homem-espaço, partindo do pressuposto de 'partes' que em dado momento entram em interação e passam então a travar uma relação dialética de reciprocidade de influência evolutiva, esta atopia transparece em toda sua consequência (MOREIRA, 2006, p. 118).

Trata-se de texto mais recente, em certa medida uma reelaboração do livro de 1988, que analisávamos, no qual o geógrafo carioca busca estabelecer com maior precisão "as fontes e a evolução" das concepções de natureza, homem e economia que orientam e fundamentam a "geografia fragmentária". Assim, após expor, no capítulo introdutório, os distintos paradigmas presentes ou hegemônicos na trajetória do pensamento geográfico, ressaltando a transição entre o paradigma holista (de fundamento iluminista e romântico) e o fragmentário (de fundamento positivista), dedica um capítulo para cada uma das "partes" - abordando o modo as concebemos e como se constituem as concepções "modernas" dessas categorias. 
Moreira busca, assim, como "nasce a base da dicotomia homem-meio característica do pensamento moderno" (MOREIRA, 2006, p. 58). O primeiro movimento nesse sentido é a "dessacralização da natureza", operada com a instituição da ciência moderna: "a natureza deixa de ser a morada de Deus e passa a ser concebida como tudo que se expresse por um conteúdo físico-matemático. Uma divisão dos fenômenos em função do conteúdo físico-matemático assim se estabelece, separando a natureza do resto dos fenômenos do mundo" (MOREIRA, 2006, p. 56). O que vale destacar, nesse segundo texto, assim como o fizemos com o mesmo Moreira no tocante à questão das escolas e matrizes, é a abordagem muito mais mediada presente em seu pensamento. Assim, por exemplo, acompanhando de maneira detalhada o surgimento dos conceitos modernos, destaca suas determinações no contexto sociopolítico e econômico:

Observa-se aqui, porém, um grande pacto entre a ciência e a religião: a ciência
cuida da coisa física, deixando o homem para a metafísica. Desta forma, o
início da modernidade acerta a relação dessacralizada e utilitária com a
natureza instituída pela ciência, abrindo para a expansão da economia mundana
que já começa a acontecer (MOREIRA, 2006, p. 57).

Tanto a institucionalidade ainda conciliada com as forças medievais (daí decorrendo o pacto com a religião) como a emergência de um novo modo de vida, marcado pelo utilitarismo, aparecem como elementos determinantes do discurso.

"Estamos, assim, perante um conceito de natureza de absoluta e recíproca relação de separação e externalidade com o homem” (MOREIRA, 2006, p. 58), continua Ruy, para asseverar:

Trata-se de um conceito de natureza que determina o de homem. A natureza penetrada da subjetividade sensível de antes cede lugar à natureza morta da objetividade insensível. O homem é a externalidade da natureza, em razão de a natureza ser uma externalidade do homem. Um não faz parte do espaço do outro. Externalidades recíprocas, natureza e homem excluem-se e se opõem (MOREIRA, 2006, p. 58).

Mais à frente, destaca ainda que "não é preciso muito esforço para se notar o vínculo que tem esta concepção mecanicista com a revolução industrial em andamento na economia das sociedades europeias" (MOREIRA, 2006, p. 60). Embora, com efeito, não fossem necessários esforços para atentar a tal vínculo, percebemos que a crítica feita à ciência geográfica acentuou, muitas vezes unilateralmente, as mediações políticoinstitucionais. Destacar e desdobrar esta outra ligação, a fim de verificar suas razões e consequências, resta como uma tarefa ainda em aberto. Inclusive porque, em realidade, ao longo dos anos 1990 assiste-se uma dinâmica muito distinta no bojo do pensamento geográfico institucionalizado, com o padecimento dos limites, obstáculos e contradições 
do movimento de renovação. À caracterização de tal momento, tomando como referência a geografia brasileira, dedicamos o próximo tópico.

\subsection{LIMITES E CRÍTICAS AO MOVIMENTO DE RENOVAÇÃO}

Não é apenas na aplicação ao ensino da disciplina, conforme vimos na apresentação, mas mesmo acerca dos próprios avanços teóricos em relação à tradição acadêmica da geografia passa-se a se reconhecer, ao menos desde 1992, quando Ruy Moreira escreve um dos primeiros balanços mais amplo sobre o processo, que os esforços no sentido da ruptura não alcançavam os fundamentos mesmos da disciplina. O bloqueio do movimento de renovação, ou mesmo seu refluxo, é identificado por vários de seus principais atores a partir dos anos 1990. Milton Santos, por exemplo, em entrevista (em 1993) reconhece que o ambiente de contestação à disciplina estabelecida, manifestado já pelo Boletim Paulista de Geografia da segunda metade de 1970 e por um artigo de Manuel Correia de Andrade, "me permitiu, quando cheguei ao Brasil, assumir uma liderança nesse movimento que durou pouco, que de certa forma abortou" (SANTOS, M., 2008 b, p. 160). Enumerando alguns dos "problemas" que afetaram o movimento de crítica logo no início da década de 1980, diz ainda que "aquela concentração de esforços que marcou o momento da explosão deixou de existir: nós, de alguma maneira, nos dispersamos, nos separamos" (SANTOS, M., 2008b, p. 161), indicando, enfim, qual seria o objetivo dos esforços e o resultado dessa dispersão, isto é, Milton Santos reafirma a necessidade da "construção teórica", da crítica epistemológica, e sua não realização:

\footnotetext{
A construção teórica é a busca de um sistema de instrumentos de análise que provém de uma visão da realidade e que permite, de um lado, intervir sobre a realidade como pensador e, de outro, reconstruir permanentemente aquilo que se chamará ou não de teoria. No meu modo de ver, essa busca teórica foi, se alguma maneira atrofiada (SANTOS, M., 2008b, p. 161).
}

No mesmo diapasão, Jorge Barcellos da Silva (1996, p. 214, grifo nosso), em dissertação de mestrado defendida em 1996, reafirma que "o rastreamento dos caminhos trilhados pelo movimento de renovação dos aspectos fundantes, hoje apresentam resultados que de certa maneira indicam mudanças formais no interior dos discursos" afirmação que, cremos, comprovamos a validez no que se refere especificamente à questão da geopolítica na geografia didático-escolar, na monografia já citada. Associado 
à inexistência de um "projeto científico, ligado a uma verdadeira varredura das suas bases fundantes e práticas" (SILVA, J. B., 1996, p. 213), verifica-se que "aquelas questões relacionadas ao desnudamento dos conceitos, à luz das práticas dessa ciência, pouco avançaram" (SILVA, J. B., 1996, p. 214).

Mais ainda, Ana Fani A. Carlos (2011, p. 21) vem alertando para o fato de que "a atual situação da Geografia revela que o pensamento crítico e radical, condição da compreensão do mundo e que assinalou mudanças profundas nos anos 1970/80 no Brasil, encontra-se agora em refluxo". Com efeito, desde, ao menos, 2002, esta autora indica que

assiste-se, hoje, a reabilitação do empirismo, a descrição do lugar, o retorno ao indivíduo para abolir o pensamento crítico e a reabilitação da evidência positivista e, com isso, em alguns casos, o retorno ao senso comum. O retorno à descrição do lugar, muitas vezes, sem a preocupação com o conteúdo esvazia a potência do debate teórico dos anos 70/80 (CARLOS, 2002, p. 166).

Por fim, comprova explicitamente o bloqueio da renovação, ou mesmo seu refluxo, o fato de ser apresentado, em 2010, como a emergência de "um novo tempo, imaturo ainda", sintetizado em uma "proposta geográfica", "o caminho suscitado por uma Geografia que pretende, em último sentido, superar uma dicotomia que é a representação acabada do problema geral posto ao saber; falamos, evidentemente, da repisada divisão entre uma Geografia Física e outra Humana” (SILVEIRA; VITTE, 2010, p. 38).

No entanto, se o reconhecimento dos limites da renovação, tanto no ensino como na ciência, converte-se praticamente em um consenso, o mesmo não se põe no que se refere ao entendimento das razões dessas limitações e, portanto, em como encaminhar (ou se isso se deve buscar) suas resoluções. O único elemento que comparece em quase todos os textos analisados, e como dimensão fundamental, é a relação do movimento de renovação com o marxismo, tanto daqueles que pretendem, em essência, a crítica e a recusa do próprio pensamento de Marx, como entre os que objetivam sua preservação ou, então, sua "atualização". Vejamos algumas dessas posições.

Desde os momentos iniciais do processo o caráter superficial da apropriação do marxismo em geral, e da obra marxiana em particular, vinha sendo apontada. Orlando Valverde, por exemplo, afirma que a incorporação "sem muita base [d]os princípios dos clássicos do socialismo" implica "uma 'leveza' nos conceitos, que atinge às raias da deformação" (VALVERDE, s/d., p. 11). Com efeito, a crítica da vulgarização ou dogmatismo tanto do marxismo que está sendo apropriado como da própria apropriação pela geografia é comum nos mais diversos tipos de avaliação. 
Ruy Moreira igualmente identifica, em seu balanço sobre o primeiro momento de renovação do pensamento geográfico institucionalizado no Brasil (de 1978 a 1988), os impasses teóricos que terminam por inviabilizar o próprio processo de crítica à ciência geográfica clássica. O geógrafo carioca identifica uma das raízes dos impasses exatamente na relação do pensamento geográfico com o marxismo. Se, de fato, temos, nesse período, a efetiva "descoberta de Marx" e mesmo a corrente marxista converte-se em hegemônica no movimento de renovação (ainda que, também para este autor, não confira qualquer tipo de identidade teórico-metodológica que franqueie a denominação de "geografia crítica") - a identificação deste com aquela termina no

\begin{abstract}
empobrecimento de ambos. A redução de um movimento de muitos entrecruzamentos a uma única face (prática natural num saber de cultura historicamente monolítica), superficializou o processo da renovação e prejudicou o florescimento de uma vertente marxista consolidada, bloqueandoa em sua chance real de acontecer. Prejudicada, ela mesma pouco vinga.

É irônica a pouca importância que os marxistas emprestam a Marxismo $e$ Geografia. Texto efetivamente marxista, circulou menos que o devido entre os próprios marxistas (MOREIRA, 2000, p. 35).
\end{abstract}

Milton Santos, por sua vez, na entrevista citada, dentre os diversos "problemas" que enumera sobre o movimento de renovação pontua que "uma boa parte dessa corrente da geografia se contentou com o marxismo de Marx, e acabou não sendo mais marxista, embora continue assim rotulada" destacando que, assim, "trabalha com uma história que não existe mais, daí uma certa fixidez dos conceitos" (SANTOS, M., 2008b, p. 161 e p. 162). Embora aparentemente semelhantes, vale atentar para as distinções das avaliações: enquanto Valverde e Moreira apontam para a deformação ou vulgarização dos pensamentos marxiano e marxista, Santos avalia que a restrição à obra de Marx (nesse momento não indicando se deformada ou não) contribui para a limitação do movimento. Embora em outros momentos também indique os limites da apropriação do marxismo ${ }^{75}$, o geógrafo baiano, em geral, reafirma a crítica em deter-se excessivamente nas categorias de Marx: "Os novos paradigmas eram tomados em estado bruto e desse modo aplicado a esses restos. Bom exemplo é o do marxismo: as categorias marxistas podem ser verdadeiras, mas o será para todas as disciplinas?" (SANTOS, 2004, p. 105), de modo que, em realidade, "esse marxismo ortodoxo, colado às fontes, obtém um papel paralisador muito mais deformante do que revelador da realidade" (SANTOS, 2004, p.

75 "No caso do marxismo: também ele era frequentemente superficial ou de segunda mão" (SANTOS, 2004, p. 106). 
107). Em suma, temos explicitamente aqui uma crítica não ao dogmatismo ou à superficialidade de apropriação do marxismo, mas à própria ortodoxia.

Outras posições vão se explicitando, ao longo dos anos 1990 e 2000. Rui Ribeiro Campos (2011, p. 535), por exemplo, em panorama recentemente publicado, afirma, mais próximo de Moreira, que, no movimento de renovação, “alguns geógrafos caíram no economicismo, aceitando que, a começar pela consciência do indivíduo, passando pelos fatos históricos, e indo até as estruturas ideológicas, tudo é determinado pelas relações de produção que compõem a estrutura econômica de uma determinada sociedade”. Ana Fani A. Carlos emite parecer análogo: “esta 'vertente' geográfica esgotou-se ao focar sua preocupação na compreensão da base material da sociedade, apegada à objetividade do espaço. Não sem consciência, prendeu-se em muitos pontos à leitura economicista de Marx (possibilidade contida nesse autor) como momentos de produção do capital" (CARLOS, 2011, p. 143). Muito embora esta autora afirme a possibilidade de um economicismo em Marx (e não apenas nas correntes que o vulgarizam ou dogmatizam), é importante seu desdobramento no sentido de que a percepção de limites "do que erroneamente se convencionou chamar de Geografia crítica" (CARLOS, 2011, p. 144) não pode/deve implicar no abandono do próprio pensamento crítico nem da teoria marxiana. Ao contrário, sinaliza no mesmo passo que

se naquele momento a pesquisa acentuou a necessidade da construção teórica,
o que permitiu questionar os limites da Geografia e as suas possibilidades de
entender o mundo, vivemos hoje um momento em que o debate teórico e o
marxismo aparecem envoltos numa nuvem de preconceito. Tal mudança foi
feita sem uma profunda e rigorosa crítica das possibilidades e limites do
pensamento de Marx, bem como da chamada Geografia crítica, fundada nessa
perspectiva teórico-metodológica (CARLOS, 2011, p. 144).

Com efeito, se críticas isoladas à própria teoria marxiana já pudessem ser notadas mesmo nos anos $1980^{76}$, é ao longo da década de 1990, com a derrocada da experiência pós-capitalista soviética e o influxo neoliberal consoante com o aprofundamento da globalização capitalista, que tais posturas se generalizam e materializam, pela primeira vez de modo explícito em um documento oficial, nos Parâmetros Curriculares Nacionais de 1997-8, no qual, ainda que se reconheça que "é inegável a contribuição do marxismo para o aluno compreender e explicar o processo de produção do espaço", em essência pretende-se afirmar que "tanto a Geografia Tradicional como a Geografia Marxista

\footnotetext{
${ }^{76}$ Cf., por exemplo, o pioneirismo de VESENTINI (1984) e SOUZA (1988), ou ainda, também “marginais", ao menos no Brasil, os geógrafos já ligados ao pensamento fenomenológico.
} 
militante negligenciaram a dimensão sensível de perceber o mundo" (BRASIL, 1998, p. 22), como forma de se justificar uma postura eclética ${ }^{77}$ que possibilite "completar" as análises fundamentadas no marxismo, que evidenciam as determinações econômicas da geografia, com as baseadas na fenomenologia. Nos termos do documento:

Se o marxismo possibilita compreender a maneira como a sociedade se organiza em torno das atividades básicas da produção e reprodução da vida material e mesmo de aspectos não-materiais como a linguagem, as crenças, a estrutura das relações sociais e as instituições, ela torna-se insuficiente como método quando se procura compreender o mundo simbólico e das representações que orientam, também, as relações com o mundo (BRASIL, 1998, p. 23).

De modo que, para considerar os referidos aspectos pretensamente inalcançáveis ao marxismo como tal, "as dimensões subjetivas e, portanto, singulares dos homens em sociedade", que se desenvolvem abordagens que rompem "tanto com o positivismo como com o marxismo ortodoxo" (BRASIL, 1998, p. 23-4). Veja-se, assim, que temos um tom e conteúdo de críticas específicos: o que se está condenando é a própria capacidade explicativa do marxismo ortodoxo, e não sua vulgarização ou dogmatização.

Com efeito, ainda que em linhas distintas, já em 1994 tornava-se possível afirmar que "na presente situação de revisão, nota-se um arrefecimento em relação às fortes disputas entre as diversas correntes geográficas que se observaram ainda na década anterior" ${ }^{78}$. Arrefecimento da disputa que converter-se-á, ao longo da década de 1990 (e, como vimos, explicita-se "oficialmente" com os PCN's), na defesa/afirmação do ecletismo. Configurando, enfim, "um ecletismo difuso e não explicitado" (MORAES, 2006, p. 39).

Esta postura eclética é fundamentada e explicitada de maneira um pouco mais aprofundada por Paulo Cesar da Costa Gomes que centra sua análise nas correntes francesa e anglo-saxã que, como vimos, de formas distintas objetivaram a apropriação do marxismo, não sem antes, no entanto, realizar sua própria crítica ao "discurso científico do marxismo". Desta feita, afirma que a "concepção de progresso social na teoria marxista reforça a ideia do mito da modernidade" e que "exatamente como em A. Comte, a ciência para Marx se torna o único meio positivo de instituir a verdade e deve servir àqueles que querem agir na sociedade" (GOMES, 2011, p. 283-4). Para além do caráter problemático

\footnotetext{
${ }^{77}$ Este ecletismo é criticado em diversas contribuições da obra Reformas no mundo da educação, em especial na de Ariovaldo Umbelino OLIVEIRA.

${ }_{78}$ Pedro Pinchas GEIGER, "Um olhar sobre a geografia no Brasil: Do Estado Novo à Nova República", p. XVII.
} 
de aproximar pensadores tão distintos no plano científico e ideológico do século XIX sem uma comprovação efetiva com base nos textos ${ }^{79}$, tal postulação é a base para afirmar a positividade de posturas recentes das "novas perspectivas da análise marxista”, entre elas, “a relativização do peso do 'cientificismo' na teoria marxista, limitando a importância do rigor metodológico, da referência às leis e do finalismo profético dos textos fundadores" (GOMES, 2011, p. 301). Tal percurso argumentativo visa defender uma postura eclética pretensamente percebida em alguns geógrafos marxistas: "a geografia abandonou o projeto de construir, por intermédio direto do marxismo, uma ciência total. Hoje, os geógrafos que invocam o marxismo o fazem a partir de uma perspectiva muito mais limitada, como uma filiação ideológica ou como uma inspiração de ordem geral" (GOMES, 2011, p. 303).

Objetivando apropriar esta discussão à geografia brasileira, Diniz Filho explicita como alguns de seus desdobramentos terminam (ou objetivam) por extirpar o conteúdo marxista efetivo das "vertentes" críticas ao propor um "repensar mais amplo da geografia crítica". Nesse sentido, o autor inicia por apontar que "os geógrafos na maioria das vezes deram pouca atenção a essa diversidade interna do marxismo" (DINIZ FILHO, 2002, p. 84), não identificando propriamente suas variadas correntes, bem como para uma "leitura dogmática das obras de Marx e dos clássicos do pensamento marxista” (DINIZ FILHO, 2002, p. 84), isto é, ao fato de que

\begin{abstract}
a assimilação do marxismo pela geografia se fez também à custa de grandes simplificações, reveladas tanto na forma de utilização das categorias marxistas fundamentais - que ganhavam conteúdos abstratos e formais, mesmo estando referenciadas a situações históricas precisas - quando na 'visão de mundo' dos geógrafos, ou melhor, em suas concepções política-ideológicas (DINIZ FILHO, 2002, p. 85).
\end{abstract}

$\mathrm{O}$ autor reconhece (no que se baseia essencialmente na obra de Gomes, acima comentada) a existência de "um certo consenso quanto ao fracasso do ambicioso projeto intelectual lançado por essa vertente vinte anos antes" como forma de referendar a "necessidade de trabalhar com várias perspectivas teóricas e metodológicas" (DINIZ FILHO, 2002, p. 105), de buscar uma “'fertilização’ mútua de influências marxistas,

\footnotetext{
${ }^{79}$ Prática, de todo modo, usual na geografia e demais ciências sociais quando da prevalência do pósmodernismo. Bastaria, nesse caso, a fim de bem caracterizar as efetivas rupturas existentes entre tais correntes, referenciar o já clássico estudo de Michel Löwy, As aventuras de Karl Marx contra o Barão de Münchausen: marxismo e positivismo na sociologia do conhecimento. Por sua vez, o educador brasileiro Dermeval Saviani, no artigo "Marxismo, educação e pedagogia" (p. 63), igualmente se insurge contra essa identificação de Marx com outros representantes do século XIX, como Comte, Spencer e Darwin: "é exatamente essa espécie de lugar-comum de nossa época que precisa ser discutido".
} 
fenomenológicas e de outras fontes" (DINIZ FILHO, 2002, p. 86) e, em sua opinião, de forma central,

\begin{abstract}
a necessidade de rever não apenas alguns postulados básicos do discurso científico do marxismo ou as insuficiências da perspectiva materialista ortodoxa no trato da temática cultural, mas também a urgência de reavaliar a visão que a geografia tem da sociedade capitalista contemporânea e das relações sociedade/espaço nesse contexto histórico concreto (DINIZ FILHO, 2002, p. 86-7).
\end{abstract}

Perceba-se que o autor iniciou por centrar sua crítica na vulgarização ou "dogmatização" do marxismo, para, em seguida, sem maiores referências, simplesmente indicar as insuficiências do "marxismo ortodoxo". De todo modo, é por esse trajeto que Diniz Filho visa, em realidade, questionar a própria validade ou atualidade das teses marxistas (mais uma vez "confundindo" por diversas maneiras ortodoxo com dogmático) na medida em que, "não havendo uma rediscussão ampla quanto à pertinência das teorias marxistas sobre o funcionamento do capitalismo atual, também não pode haver uma reavaliação da postura político-ideológica dos geógrafos” (DINIZ FILHO, 2002, p. 101). Curioso perceber que embora o autor proponha uma "rediscussão ampla" da pertinência do marxismo em geral no entendimento do mundo contemporâneo, já explicita (sem propriamente fundamentar tais posições, baseando-se tão somente num debate publicado na revista Lua Nova entre autores que há muito não se identificam com o marxismo, ou nunca o fizeram) as conclusões necessárias:

O que se quer frisar aqui é que as representações e valores simbólicos que compõem a "visão de mundo" dos geógrafos frente ao capitalismo contemporâneo (em que pesem algumas declarações autocríticas) continuam profundamente matizados pelos vícios característicos do marxismo vulgar, conforme já apontado: menosprezo pela democracia, estatismo estreito e visão puramente negativa do mercado (DINIZ FILHO, 2002, p. 102).

Embora se aponte corretamente para os limites de um "estatismo estreito", presente não apenas na geografia brasileira mas mesmo na "esquerda" (ou assim reconhecida) mundial e de longas raízes, a avaliação do autor sobre os outros dois elementos indicam questões fundamentais do próprio pensamento marxiano em sua origem: a crítica da política e da democracia e da economia política (a "visão puramente negativa do mercado"). Temos, enfim, a refutação, ainda que de maneira abstrata, de elementos fundamentais do próprio pensamento de Marx - que, em realidade, constituem sua essência, a crítica da politicidade (inclusive, e fundamentalmente, da emancipação 
política, reconhecidos seus avanços) e a crítica da sociedade burguesa e da relação social que a fundamenta (o capital) ${ }^{80}$.

Ana Fani A. Carlos (2007) direcionou uma crítica certeira ao artigo em tela:

a elaboração da crítica requer como premissa o conhecimento do assunto e aqui se identifica automaticamente, o pensamento de Marx com a 'leitura enviesada' que alguns geógrafos fizeram da obra do mesmo. A ausência de rigor e a generalização sobre este legado para a Geografia desembocam num discurso ideológico e preconceituoso.

Enfim, não nos é possível - tanto por nossos limites e os de uma dissertação, como, em nossa opinião, também pelos limites do próprio debate realizado - apontar aspectos definitivos acerca dessa relação entre marxismo e geografia. Vale perceber, nesse sentido, que embora os autores identifiquem a presença de um economicismo no movimento de renovação (ou mesmo no próprio pensamento marxiano) usualmente não efetivam a comprovação com base nos textos. O que podemos reconhecer com certa clareza, portanto, é o relativo bloqueio do processo de renovação - o que não impede, é claro, avanços - ao longo da década de 1980, o que termina por não viabilizar uma reformulação categorial efetiva e, portanto, uma verdadeira renovação de suas práticas acadêmicas e escolares. É o aprofundamento dos estudos, pesquisas e debates que permitirá desnudar os limites efetivos das tentativas de renovação, identificando suas razões e determinantes, bem como os interesses sociais envolvidos na polêmica, afinal, é válido reconhecer que a disputa em torno do que se deu é, igualmente, a disputa em torno do que pode ou deve se realizar. Tal discussão ganha importância redobrada se inserida no momento de recomeço da história ${ }^{81}$, tendo como eixo central dimensões da vida cotidiana, em específico, sua geografia. Isto é, é a própria organização socioespacial das cidades brasileiras que é questionada, em essência, nas já conhecidas como "jornadas de junho" e a cotidianidade por elas imposta, se seguirmos a análise fulcral de Lefebvre (1991).

O que podemos perceber, de todo modo, é que, se a crítica da ciência geográfica inicia-se pela crítica ideológica e política, "é pouco objetiva em sua progressão da fase ideológica para a epistêmica" (MOREIRA, 2000, p. 38) - no sentido específico de desnudamento e problematização de suas categorias fundantes e fundamentos teóricometodológicos. Conforme reconhece Martins (1996, p. 5), "na história desta disciplina já

\footnotetext{
${ }^{80}$ Discutiremos amplamente tais dimensões no próximo capítulo.

${ }^{81}$ Tantas vezes dada como "finalizada", em especial ao longo dos anos 1990, exatamente quando se propõe a "fusão" das diversas correntes filosóficas, tal como esquadrinhado.
} 
ficaram minimamente esclarecidas as tradições de suas práticas, ou então seus comprometimentos sociais. Quanto a sua estrutura teórico-epistemológica, encontramos, entretanto, uma frequência menor de preocupações que revelem as raízes mais profundas do seu discurso".

Moreira e Silva concordam, ainda, nos fundamentos categoriais em que a ausência de crítica é mais evidente: nas categorias de natureza e homem. A nosso ver, então, talvez desdobrando a crítica de Moreira, temos uma efetiva limitação da crítica ao discurso geográfico no âmbito da ontologia, isto é, no aspecto propriamente relacionado às concepções acerca do ser - tanto do ser em geral como do ser social. J. B. da Silva (1996, p. 214), por exemplo, afirma que o limitado avanço no desnudamento dos conceitos tem, como "exemplo maior" o

grau de aprofundamento que os geógrafos 'físicos' estabeleceram em torno do conceito de natureza, que ainda, em muitos casos, é vista nos moldes newtonianos. Ou por outro lado, pelos geógrafos 'humanos' em torno do conceito de população, que na maior parte das referências gira, ainda, na perspectiva liberal de estarmos falando de um homem genérico, sem identificação de classes sociais.

Ruy Moreira (2000, p. 39), no mesmo sentido, aponta que o elemento central, desconsiderado, no andamento da crítica do político-ideológico para o epistêmico, é a questão do "sujeito", isto é, que

\begin{abstract}
a impregnação do oficialismo, objeto da crítica, ampliada de uma conjuntura de saída da ditadura, confunde contudo a reflexão epistêmica com o tema da ação política imediata, levando ao enfoque mais sociológico que ontológico do sujeito e a cair-se numa espécie de militantismo com sinal trocado. Localizase aqui uma primeira dificuldade: a visão puramente militantista confunde a questão do sujeito e desloca o seu debate para uma interminável discussão do objeto.
\end{abstract}

No limite, o tema do sujeito ficou subalterno à discussão do objeto.

Objeto que corresponde, no movimento da renovação, ao "espaço": "É esta fórmula de falar-se do espaço, falando-se do sujeito da história, o problema do salto do movimento do estágio da crítica do político-ideológico para o epistêmico" (MOREIRA, 2000, p. 39).

Ou seja, na realidade, embora se tenha visto uma progressão da crítica ao pensamento geográfico clássico no âmbito da epistemologia, parece-nos não ser possível afirmar que esta crítica alcança a dimensão dos fundamentos ontológicos do discurso geográfico. Vale dizer que não questionamos, em absoluto, o valor do aprofundamento das pesquisas na discussão conceitual - das ferramentas do pesquisador e do geógrafo. Apontamos, no entanto, o que julgamos uma ausência crucial - na medida em que se 
configura, em realidade, numa questão prévia à problematização conceitual, epistemológica - a questão do ser, ontológica. Parece ser essa, também, a posição de Ruy Moreira no artigo supracitado quando reconhece que "há aqui provavelmente um tributo pago ao viés economicista do marxismo que está se absorvendo na renovação, um marxismo vazio de reflexão ontológica", isto é, se "desde o primeiro momento da renovação, o trabalho desponta como a essência concreta do espaço", na realidade, "o trabalho é concebido como a mediação de relações que se dão na produção de bens materiais, e tem por conteúdo explícito esse metabolismo entre a natureza e o homem que é a atividade econômica" (MOREIRA, 2000, p. 39).

Isto é, temos uma redução do estatuto do trabalho à dimensão econômica "e, no limite, os fundamentos econômicos se encerram na sua transformação no social a produção do espaço nunca aparece portanto como um processo de hominização do próprio homem", para concluir com as consequências fundamentais: "Fica, então, desprezada a questão essencial da alienação do trabalho (e do seu sujeito) no espaço do capitalismo" e, mais, temos um "problema que surge da discussão superficial do tema do sujeito, da sua sujeição a um entendimento puramente axiológico, isto é, o espaço como valor e determinação, e não ontológico" (MOREIRA, 2000, p. 39).

Em texto mais recente, Élvio Rodrigues Martins (2007, p. 46), a partir da análise de La Blache e Pierre George, isto é, no trânsito da Geografia Clássica para a Geografia Ativa, indica questão análoga:

\begin{abstract}
estes geógrafos confundiram existência com sobrevivência. A sobrevivência é a dimensão material da existência. A sobrevivência é a relação orgânicoinorgânico. É seguramente do Trabalho que devemos falar. Mas não nos termos delimitados por Pierre George, ou seja, trabalho definido em função dos condicionamentos bioclimáticos, ou caracterizado por seus fatores técnicos ou mesmo econômicos. Devemos ir além, na direção de ver no Trabalho o ato de autoprodução do homem, ou seja, da definição de sua humanidade, da definição do seu complexo bio-ontológico, passando ser a atividade por meio da qual, e na qual, somente o homem se torna aquilo que ele é como homem, segundo sua essência.
\end{abstract}

O interessante, então, é perceber a manutenção dessa restrição do estatuto do trabalho ao âmbito da sobrevivência, como coloca Martins, mesmo no bojo da crítica à geografia clássica.

É em População e geografia, obra publicada em 1992, que temos uma problematização, aparentemente, no sentido proposto, de superar certo economicismo após o reconhecimento da necessidade de superação, na análise da "população", do "quantitativismo" que "leva à imagem superficial deste fenômeno social, para quem quer 
lhe captar, exatamente, a essência qualitativa, as relações escondidas" (DAMIANI, 2006, p. 7), e a partir da incorporação da obra do pensador marxista francês Henri Lefebvre quando afirma a possibilidade de substituição do conceito de população, que se esvazia, "sobretudo uma forma de controle e conhecimento sobre as pessoas, que não tem data" (DAMIANI, 2006, p. 78) pela noção de "produção do homem": “o homem, ou o ser humano, não é um fato dado, pronto, acabado, que sempre esteve presente do mesmo modo, ao longo de toda a história. A história é, também, a história da formação, do nascimento do homem como ser humano" (DAMIANI, 2006, p. 78). Reconhecendo, o que é importante frisar, o caráter mais amplo da noção de produção e, assim, a dimensão central da humanização: "o homem produz um mundo humanizado, fora dele e dentro dele. Não só produz objetos materiais, a partir de material original da natureza, mas objetos especificamente sociais, que não guardam nenhuma materialidade natural" (DAMIANI, 2006, p. 79). Em suma, "estamos diante, portanto, do tratamento da 'população', não apenas como um recurso, um ator, um problema (através da superpopulação), mas, na concepção da produção do homem, como um projeto" (DAMIANI, 2006, p. 84). Posições que levam a autora, então, à abordagem profícua de temas pouco comuns em análises geográficas e/ou "populacionais": dissociação entre gozo e fecundidade, a expropriação/reapropriação do corpo (em especial da mulher), vida cotidiana e reprodução das relações sociais, o "estrangulamento" da vida coletiva, a vida espontânea e o desejo, as diferenças etc ${ }^{82}$.

Vale reconhecer, acerca desse estudo, a importância da apropriação de Henri Lefebvre, pensador que ocupa posição singular no âmbito do marxismo ocidental. Ou melhor, em realidade, ao seguirmos a proposição de José Paulo Netto acerca dessa categoria $^{83}$, que não se inclui nessa tradição. Com efeito, associado ao propósito de recuperar a obra própria de Marx $^{84}$ é possível identificar certos pendores a seu

\footnotetext{
${ }^{82}$ Cf., DAMIANI, 2006, pp. 84-102.

${ }^{83}$ De que o que "poderia peculiarizar o marxismo ocidental consiste precisamente na recusa de uma concepção ontológica (no sentido em que o velho Lukács a tematizou) da teoria social de Marx, seja a título de um historicismo radical-abstrato, seja a título de um viés epistemologista, seja, enfim, a título de salvaguardar a especificidade da socialidade ameaçada pelo ontologismo de leituras da 'dialética da natureza' que tendem a equalizar natureza e história. Este cariz não-ontológico e/ou antiontológico articula a teorização própria do marxismo ocidental" (NETTO,1996, p. 9.)

${ }^{84}$ Por exemplo, em $O$ pensamento marxista e a cidade: "Trata-se antes de mais de reunir textos dispersos relendo o conjunto das obras de Marx e de Engels, 're-leitura' que em si mesma nada tem de particular" (LEFEBVRE, 1972, p. 7). Ou ainda, em Sociologia de Marx: "Este curto estudo insere-se naquilo que já denominamos: uma nova leitura de Marx. Trata-se de uma interpretação? Não. Trata-se antes de mais nada de uma revisão que se tornou necessária, graças ao desenvolvimento contraditório do pensamento marxista
} 
entendimento enquanto uma ontologia (histórica e social), muito embora a denomine de sociologia ou antropologia ${ }^{85}$.

Após seu nascimento (individual e histórico), o homem, ser da necessidade, permanece por muito tempo fraco e desarmado. Pergunta-se como puderam os homens sobreviver, crianças desfavorecidas pela cruel genitora, a natureza. Seria o homem, enquanto ser da necessidade, para Marx e para o pensamento marxista, objeto de uma ciência particular que se poderia chamar de antropologia? Sem dúvida. Os manuscritos de 1844 esboçam essa antropologia e ao mesmo tempo contêm a sua crítica. /.../. O fundamento do ser humano na natureza pode legitimamente ser tomado por ontológico (LEFEBVRE, 1979, p. 31).

Igualmente a distinção entre o sentido lato, herdado da filosofia, e o sentido restrito, compartilhado com a economia, da noção de produção, que desemboca, assim, na apreensão da auto-produção humana, pode ser apreendida da obra de Lefebvre (cf. 1972, p. 47). Em A vida cotidiana no mundo moderno, por exemplo, afirma: "Esta obra comporta uma interpretação do pensamento marxista sobre a qual é preciso insistir. /.../. Num retorno às fontes, ou seja, às obras de juventude de Marx (sem, no entanto, deixar de lado O capital), o termo produção readquire um sentido amplo e vigoroso" (LEFEBVRE, 1991, p. 37).

Por enquanto, vale reter que estes elementos parecem comprovar o fato de que a renovação do marxismo implica, em primeiro lugar, o retorno à obra de Karl Marx, entendida enquanto uma ontologia do ser social - como a apreensão, o reconhecimento das categorias básicas, fundantes e fundamentais, dessa esfera do ser, isto é, dos “pressupostos reais, de que só se pode abstrair na imaginação" (MARX; ENGELS, 2007, p. 86) - que emerge no seio de seu intento crítico direcionado à realidade de sua época com vistas à superação de toda alienação e exploração ${ }^{86}$. Coadunando, assim, com a necessidade de superação de leituras parciais ou insuficientes, comuns no que já se pode reconhecer como o destino trágico ${ }^{87}$ (ou seu desenvolvimento contraditório, nos termos de Lefebvre) do pensamento de Marx, optamos, prioritariamente, nesse momento, pela

e do mundo moderno" (LEFEBVRE, 1979, p. 7).

${ }^{85}$ E nos parece que, no caso de Lefebvre, a questão terminológica é secundária em relação ao seu conteúdo. Vale lembrar ainda que, ao tempo em que o pensador francês produz a maior parte das obras aqui tratadas, mesmo Lukács receava o uso do termo e guardava diferentes reservas, dado que, então, tratar de ontologia em geral referia á heiddegeriana.

${ }^{86}$ Em carta a Ruge, Marx afirma que seu objetivo mais amplo é a "crítica inescrupulosa da realidade dada; inescrupulosa tanto no sentido de que a crítica não pode temer os seus próprios resultados quanto no sentido de que não pode temer os conflitos com os poderes estabelecidos" (MARX, 2010); sustentando, ainda, num texto publicado juntamente com a carta anterior nos Anais franco-alemães, “/... o imperativo categórico de derrubar todas as condições em que o homem surge como ser humilhado, escravizado, abandonado, desprezível" (MARX, 2005, p. 151).

${ }^{87}$ Problematizado, por exemplo, num âmbito específico, e fundamental para o nosso trabalho, por Ester VAISMAN (1996). 
lida direta com o texto marxiano. Como já apontara, aliás, o pensador responsável exatamente pela recuperação do caráter ontológico do pensamento marxiano: "se o marxismo quer hoje voltar a ser uma força viva do desenvolvimento filosófico, deve em todas as questões retornar ao próprio Marx” (LUKÁCS, 1979, p. 34).

Se, com efeito, no próprio processo de renovação há "provavelmente um tributo pago ao viés economicista do marxismo que está se absorvendo na renovação, um marxismo vazio de reflexão ontológica" (MOREIRA, 2000, p. 39), a incorporação decisiva da obra marxiana (enquanto ontologia) ganha, no contexto da ciência geográfica, uma dimensão fundamental: parece-nos ser a forma mais adequada de operar a crítica/subversão efetiva aos/dos fundamentos teórico-metodológicos da tradição acadêmica constituída. Não foi este, no entanto, como vimos, os rumos encetados na ciência geográfica, que acompanhou os mais gerais do pensamento no final do século XX, busca "completar" ou "refundir" Marx com distintas correntes teóricas. Nesse sentido, vale destacar que acompanhamos o duplo entendimento de que

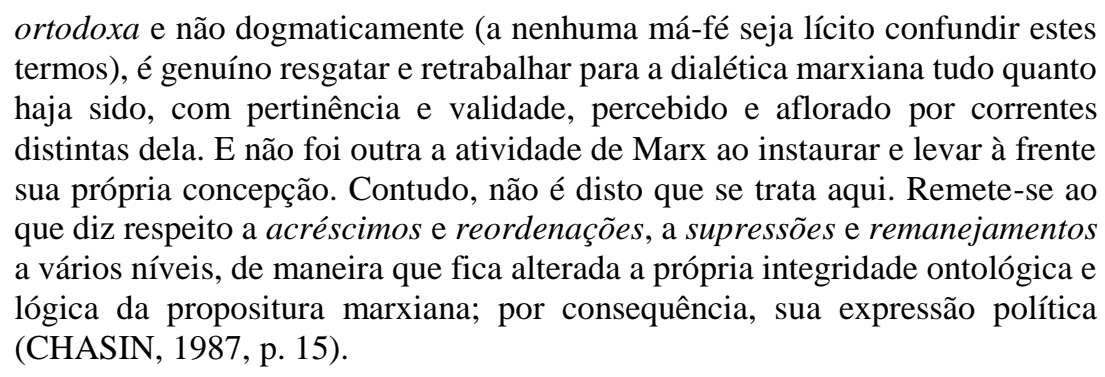

De modo que, efetivamente, nos capítulos posteriores, buscamos resgatar e retrabalhar princípios e categorias emergidos em outras e posições teóricas, mas não sem antes expor o essencial da concepção marxiana, no intuito de preservar sua integridade ontológica. 


\section{CAPÍTULO 2 - CRÍTICA FILOSÓFICA E ESTATUTO ONTOLÓgico: A CONSTITUIÇÃO DO PENSAMENTO MARXIANO}

Este capítulo pretende, através da análise do processo de formação do pensamento de Marx - as três críticas ontológicas por ele realizadas originariamente entre os anos de 1843 e 1844 -, identificar e problematizar seus princípios fundantes, isto é, seu caráter ontológico, especificamente no tocante ao entendimento do ser social e de suas categorias essenciais (dentre as quais avultam a individualidade social e o processo de individuação). Para tal compreensão, é necessário situar e contextualizar, de maneira a mais concreta possível, este momento da obra de Marx.

É o próprio pensador alemão, no famoso trecho autobiográfico de seu "Prefácio" à Contribuição à crítica da economia política, de 1859, quem indica o momento exato do início da formatação de sua nova posição teórica: "o primeiro trabalho que empreendi para resolver a dúvida que me assediava foi uma revisão crítica da filosofia do direito de Hegel, trabalho este cuja introdução apareceu nos Anais Franco-Alemães, editados em Paris em 1844" (MARX, 1982, p. 24). Trata-se do estudo Crítica da filosofia do direito de Hegel realizado quando resolve, após sua primeira experiência como jornalista no periódico Gazeta Renana, se "retirar do cenário público para o gabinete de estudos", estabelecido em Kreuznach, entre julho e outubro de 1843 (RUBEL, 1991, P. 25) ${ }^{88}$, publicado pela primeira vez apenas em 1927.

É importante reter outro elemento presente na afirmação acima de Marx - este trabalho, isto é, a revisão crítica da obra Princípios da filosofia do direito, pulicada por Hegel em 1820, é empreendido com o objetivo explícito de solucionar dúvidas que o assediavam. Verificar, então, o caráter dessas dúvidas é um primeiro passo necessário à apreensão de seu pensamento, na medida em que, como veremos, este estudo dá início a

${ }^{88}$ Celso Frederico $(1995$, p. 51$)$ assim resume o contexto do texto e indica elementos sobre sua denominação: "Afastado de suas atividades jornalísticas, após o fechamento da Gazeta Renana, procurou dar continuidade à luta então travada contra o Estado prussiano. Para isso, lançou-se à leitura do texto hegeliano, tarefa que realizou durante sua lua-de-mel na cidade de Kreuznach. O resultado final desse estudo está no manuscrito Crítica do Estado Hegeliano, segundo a tradução francesa de Kostas Popaioanou, ou Crítica da filosofia do direito de Hegel, numa sofrível e incompleta tradução portuguesa, ou ainda, como preferiu Della Volpe, Crítica da filosofia hegeliana do direito público. Os estudiosos de Marx também se referem ao texto como Manuscritos de Kreuznach". Em geral, seguimos, aqui, a denominação portuguesa, adotada na edição brasileira. 
um conjunto de trabalhos que resultam na instauração de uma ontologia estatutária do ser social. Acerca dessa questão, Marx lembra que "nos anos de 1842/43, como redator da Gazeta Renana vi-me pela primeira vez em apuros por ter que tomar parte na discussão sobre os chamados interesses materiais" (MARX, 1982, p. 24). Recém-saído da universidade prussiana, na qual, aliás, foi impedido de lecionar exatamente por seu posicionamento político democrático ${ }^{89}$, Marx é obrigado, na condição de jornalista, a lidar com as questões políticas e econômicas da ordem do dia:

As deliberações do Parlamento renano sobre o roubo de madeira e parcelamento da propriedade fundiária, a polêmica oficial que o Sr. Von Schaper, então governador da província renana, abriu com a Gazeta Renana sobre a situação dos camponeses do vale do Mosela, e finalmente os debates sobre o livre-comércio e proteção aduaneira, deram-me os primeiros motivos para ocupar-me de questões econômicas (MARX, 1982, p. 24).

Ao deter-se, porém, nas referidas questões econômicas, o filósofo recémdoutorado depara-se com a inadequação ${ }^{90}$ de suas concepções neohegelianas em fornecer a explicação concreta - já entendida como meio necessário para sua resolução - das contradições sociais da Alemanha, em pleno caminho prussiano de desenvolvimento do capitalismo 91 . Isto é, "desde que tivera de examinar problemas sociais concretos, faceou os limites e viu questionada a validade de sua base teórica primitiva" (CHASIN, 2009, p. $54)^{92}$, de modo que, frente à decisão dos proprietários do jornal em encerrar suas atividades (devido pressão da censura prussiana), retira-se ao "gabinete de estudos", no qual se dedica a superar os limites teóricos constatados.

\footnotetext{
${ }^{89}$ No caso, sua vinculação com o grupo de Bruno Bauer: “A expulsão de Bauer da Universidade de Bona teve como resultado fechar as portas desta universidade ao seu amigo Marx. A carreira acadêmica foi proibida a Marx no preciso momento em que ele obtinha o direito formal de a iniciar" (LÁPINE, 1983, p. 60)

${ }^{90} \mathrm{O}$ que não o impediu tornar-se uma das principais vozes da oposição prussiana: "Sob a orientação de Marx o Rheinische Zeitung se tornou a voz liberal da Prússia”; “/.../ conforme Marx foi amadurecendo como jornalista, o jornal foi se tornando mais radical. O Rheinisch Zeitung era inquebrantável em sua cobertura da dieta renana e do governo em Berlim, meticuloso na apresentação dos fatos (da forma como os viam seus editores), profundo em suas análises e zombeteiro no tom. Falava às classes instruídas da Prússia com uma voz ousada e nova, e as assinaturas subiram de quatrocentas para 3500 no primeiro ano" (GABRIEL, 2013, p. 66 e 68). Com efeito, "En esta prueba de fuerza prolongada entre el liberalismo renano y la autocracia prussiana, la Rheinische Zeitung desempeño el papel de um proto partido de la sociedad civil" (BENSAÏD, 2011, p. 11).

91 É o próprio Marx que, posteriormente, aponta elementos centrais acerca da particularidade do desenvolvimento capitalista alemão, mas é Lênin que caracteriza-o como o "caminho do tipo prussiano", distinto do "caminho de tipo norte-americano", da via clássica, revolucionária, de desenvolvimento. Cf. Vladmir I. LENIN, (1980). Antonio Carlos R. MORAES (2002) sintetiza aspectos relacionados à especificidade da via prussiana, em especial a partir de Lukács, relacionando-os com o desenvolvimento da geografia moderna.

${ }^{92}$ Um dos principais questionamentos, como veremos, se dará no âmbito da política e do estado, enquanto meios da universalidade e liberdade. Sobre a concepção da política de Marx nesse período, cf. Celso EIDT (2001).
} 
A fim de verificar a questão da individualidade na obra de Marx, e sua recente recuperação, vale reter um comentário de Dermeval Saviani - de que o interesse originário de Marx, como enunciado pelo mesmo, corresponde em realidade às ações e problemas individuais concretos. Tomando-se como parâmetro a questão do roubo da lenha ${ }^{93}$, o educador brasileiro afirma: "na base, portanto, de sua crítica à filosofia do direito de Hegel estavam indivíduos reais, sujeitos de uma prática efetiva, os camponeses do Mosela que eram ameaçados de ter impedida a satisfação de suas necessidades vitais pela acusação de roubo de lenha" (SAVIANI, 2012a, p. 25). Adam Schaff (1967, p. 67), em pesquisa acerca especificamente da questão do indivíduo, ademais, anota o fato de que a reflexão sobre este e os seus dilemas constituía elemento do tempo de Marx, pósrevolucionário:

Os velhos sistemas de valores estavam destruídos, os novos, prestes a se formar, provocaram protestos e críticas. Mais agudo do que nunca - franco e expresso - foi o problema do indivíduo, que errava e deseja estabilização, que aparecia subjugado e buscava a liberdade, que sofria explorações e exigia a plenitude da vida, que se mostrava dividido e exigia felicidade. O problema dominou a época, porque era uma época de transformação e revolução.

Enfim, são os "interesses materiais", a configuração concreta do ser social no momento determinado, sua prática num momento histórico específico, com seus problemas econômicos, políticos e sociais, que encaminham Marx à crítica da teoria do estado hegeliano e, atravessando a refutação de seus procedimentos metodológicos especulativos, ao início da estruturação de um pensamento original ${ }^{94}$. E a crítica dirigese à teoria hegeliana na medida em que esta é identificada como a elaboração de ponta do seu próprio tempo histórico. Ou seja, os objetos da crítica de Marx são as elaborações teóricas mais sofisticadas de sua época que, enquanto tais, são capazes de reproduzir idealmente os modos de ser da sociedade moderna, ainda que de uma forma invertida ou naturalizada, ahistórica, como o próprio Marx indicará, na forma de acusação, em distintos momentos de sua produção teórica. Podemos exemplificar, seguindo o próprio Marx, com a filosofia hegeliana do direito, na medida em que "a filosofia alemã do direito e do Estado é a única história alemã que está al pari com a época moderna oficial"

\footnotetext{
${ }^{93}$ Trata-se da série de artigos de Marx sobre a lei proposta pelo Imperador Frederico Guilherme IV à Dieta renana, que passava a considerar crime a coleta de lenha por parte dos camponeses pobres, prática que compunha o direito consuetudinário germânico, publicada entre 25 de outubro e 3 de novembro de 1842 . Trechos desses artigos, precedidos de uma introdução alentada, encontram-se em Daniel BENSAÏD (2013). ${ }^{94}$ Mary GABRIEL (2013, p. 67) igualmente identifica a centralidade desse período no epistolário marxiano: "Marx ficou em Colônia, enfiado até os cotovelos na pesquisa para o primeiro de dois artigos que mais tarde ele diria a Engels: 'me levaram da política pura e simples às condições econômicas, e assim ao socialismo"”.
} 
(MARX, 2005, p. 150), isto é, enquanto na vida política real a Alemanha, dominada pelo mais "asqueroso despotismo" (MARX, 2010, p. 70), depara-se com o passado dos países europeus democráticos ${ }^{95}$, a filosofia alemã representa a efetiva compreensão da natureza e funcionamento do Estado moderno (ainda que não o de sua origem ou necessidade, da razão de sua existência):

A crítica da filosofia alemã do direito e do Estado, que teve a mais lógica, profunda e completa expressão em Hegel, surge ao mesmo tempo como a análise crítica do Estado moderno e da realidade a ele associada e como negação definitiva de todas as anteriores formas de consciência na jurisprudência e na política alemã, cuja expressão mais distinta e mais geral, elevada ao nível de ciência, é precisamente a filosofia especulativa do direito. /.../. Em política, os alemães pensaram o que as outras nações fizeram. A Alemanha foi sua consciência teórica (MARX, 2005, p. 151).

Numa palavra: Marx realiza a crítica da consciência teórica do Estado moderno e da realidade a ele associada, sendo, portanto, igualmente uma crítica a estes, em suma, "Marx considerava a Filosofia do direito de Hegel como a mais refinada expressão teórica do Estado moderno e, portanto, para o jovem publicista, criticar a obra equivalia a criticar a própria realidade que lhe servia de referência" (FREDERICO, 1995, p. 52). Daí, enfim, poder-se compreender esta, e as demais críticas realizadas nesse período, como críticas ontológicas, isto é, críticas aos modos de ser da realidade social.

Então, entre 1843 e 1844 - a partir de sua retirada ao "gabinete de estudos" e a formulação pioneira da Crítica da filosofia do direito de Hegel até, como marco, a redação dos Manuscritos econômico-filosóficos, em Paris - Marx realiza uma profunda crítica da realidade de sua época, a partir do exame cuidadoso (crítico) das formulações teóricas que a representava em pensamento - e constituíam, em realidade, sua própria consciência filosófica, enquanto autor neohegeliano. Embate do qual resultará uma concepção do mundo e dos homens própria e singular, no âmbito de toda a história da filosofia - a ontologia do ser social e que se inicia a partir de questionamentos e inquietações relativas ao modo de ser dos homens de sua época.

Pode-se, assim, reconhecer que

as três críticas instauradoras dão contorno nascente a uma visão global de mundo, uma vez que tem por objetos a prática, a filosofia e a ciência, respectivamente nas formas da política, da especulação hegeliana e da economia política clássica, admitidas como expressões de ponta da elaboração teórica de toda uma época, por isso mesmo enfrentadas como os circuitos

\footnotetext{
95 "A luta contra o presente político dos alemães é a luta contra o passado das nações modernas, que ainda se vêem continuamente importunadas pelas reminiscências do seu passado" (Karl MARX, 2005, p. 147).
} 
esgotados de um patamar de atividade e racionalidade que cabe superar (CHASIN, 2009, p. 78).

Acompanhemos, então, este trajeto.

\subsection{DA CRÍTICA DA RELIGIÃO À CRÍTICA DA FILOSOFIA ESPECULATIVA: A POSIÇÃO ONTOLÓGICA MARXIANA}

Neste tópico pretendemos analisar a crítica ontológica da filosofia especulativa, simultânea à crítica da política - efetivada inicialmente, contra Hegel, no manuscrito supracitado, que restou inacabado, Crítica da filosofia do direito de Hegel, e nos Manuscritos econômico-filosóficos (aqui já direcionada também à economia política clássica) e continuada (exercitada, diria Chasin) num conjunto amplo e variado de escritos “em especial sobre textos do cenáculo de Bauer e os escritos de Stirner e Proudhon, aos quais estão voltados, um após outro, nada menos do que $A$ sagrada família, A ideologia alemã e Miséria da filosofia" (CHASIN, 2009, p. 66-7). Desse momento, no qual se ressalta a relação com L. Feuerbach (1804-1872) ${ }^{96}$, dois elementos positivos (isto é, afirmados/defendidos por Marx) nos interessam sobremaneira para o desdobramento do trabalho: a afirmação de uma nova ontologia - fundada na objetividade sensível - e a consequente redefinição do papel da consciência e do pensamento humano, portanto, da própria crítica. Dois elementos positivos que se associam a um suposto, um momento negativo: o rechaço à especulação hegeliana, sua posição teórica anterior.

Iniciamos a abordagem desse trajeto pela crítica da filosofia especulativa, enquanto refutação decisiva e definitiva da especulação, na medida em que ela se associa intimamente, por sua vez, à crítica da religião, levada a efeito no seio do movimento neohegeliano ${ }^{97}$ e sintetizada por Feuerbach; é o que se depreende da frase inicial da "Introdução"98 à Crítica da filosofia do direito de Hegel: "no caso da Alemanha, a Crítica da religião chegou, no essencial, ao seu fim; e a crítica da religião é o pressuposto de toda a crítica” (MARX, 2005, p. 145) e, igualmente, dos trechos iniciais dos Manuscritos econômico-filosóficos: "a crítica da economia nacional deve, além do mais, assim como

\footnotetext{
${ }^{96}$ Com efeito, "a esmagadora maioria dos analistas considera que a matriz dominante da Crítica de 1843 é o trabalho que Feuerbach vinha desenvolvendo desde 1839" (NETTO, 1983, p. 183)

97 "Toda a crítica filosófica alemã de Strauss a Stirner limita-se à crítica das representações religiosas" (MARX; ENGELS, 2007, p. 83).

${ }^{98}$ Texto escrito no final de 1843 , após, portanto, a redação da Crítica propriamente dita e em relação à qual guarda consideráveis diferenças. Cf. Rubens ENDERLE (2000).
} 
a crítica positiva em geral, sua verdadeira fundamentação às descobertas de Feuerbach" (MARX, 2004, p. 20). Ou, ainda, da própria A ideologia alemãa, cuja primeira parte é integralmente voltada para sua crítica, ao reconhecer que as considerações gerais acerca do pensamento neo-hegeliano são contrapostas "especialmente a Feuerbach, pois ele é o único que fez ao menos algum progresso e cujos escritos podem ser examinados de bonne foi" (MARX; ENGELS, 2007, p. 86, nota $c$ ).

Em resumo, a referida crítica (ou a descoberta de Feuerbach) corresponde à identificação da religião como uma forma da alienação da essência humana - de projeção das características essenciais do homem num ser exterior que se converte (idealmente) em seu criador, no verdadeiro sujeito, isto é, ao fato que o homem "na realidade fantástica do céu, onde procurara um ser sobre-humano, encontrou apenas o seu próprio reflexo" (MARX, 2005, p. 145). Em outros termos, os de uma das principais obras desse reconhecimento, temos que "o homem - e este é o segredo da religião - objetiva a sua essência e se faz novamente um objeto deste ser objetivado, transformado em sujeito, em pessoa" (FEUERBACH, 2007, p. 58). Enfim, “é este o fundamento da crítica irreligiosa: o homem faz a religião, a religião não faz o homem” (MARX, 2005, p. 145).

A relação de Marx com Feuerbach constitui, dentre os estudiosos da obra marxiana, dos temas mais polêmicos ${ }^{99}$ e o cerne mesmo da igualmente polêmica distinção entre um “jovem Marx" - até por volta d'A ideologia alemã, obra escrita entre 1845-6, ou mesmo até o Manifesto do partido comunista, de 1848 -, em que seriam patentes os "resquícios" neohegelianos (ou, mais especificamente, feuerbachianos), e o "velho Marx", a obra verdadeiramente científica ${ }^{100}$. Não nos é possível, nem compõe o objetivo deste trabalho, adentrarmos nessa discussão. Basta o reconhecimento, que problematizaremos ao longo da própria explicitação do pensamento de Marx, de que é

impossível, pela voz dos próprios textos, ouvir um Marx feuerbachiano, mas são perfeitamente audíveis certos acordes de Feuerbach nas partituras

\footnotetext{
${ }^{99} \mathrm{Cf}$., por exemplo, na produção brasileira mais recente, além dos estudos mais amplos aqui utilizados, como os de José CHASIN e Celso FREDERICO, os ensaios deste último com Benedicto Arthur SAMPAIO (2009) e os mestrados de Lucia A. V. SARTÓRIO (2001) e Rodrigo Maciel ALCKMIN (2003).

100 Tal polêmica não deixa de constituir um ponto a ser melhor explorado na ciência geográfica, em especial suas repercussões teóricas de fundo, na medida em que um de seus principais contendores, o estruturalista francês L. Althusser, exerce grande influência através das obras de Yves Lacoste ["a referência epistemológica essencial de Lacoste é Althusser, citado explicitamente, e que serve manifestamente de modelo epistemológico para repensar ou pensar o espaço" (DOSSE, 1994, p. 352)] e de algumas de Milton Santos, como a seminal Por uma geografia nova, dentre diversas outras da sua renovação crítica. Soja (1993, p. 69) afirma ainda que "embora raramente se explicitasse, este ou aquele tipo de epistemologia estruturalista (Harvey, por exemplo, seguiu Piaget mais do que Althusser em A justiça social e a cidade) infundiu-se quase que sublinarmente em todo o desenvolvimento inicial da geografia marxista".
} 
marxianas. Na crítica à filosofia especulativa, especialmente na recusa à especulação como método científico, eles muito sonoramente estão presentes, mas reintegrados à textura da composição marxiana (CHASIN, 2009, p. 69).

Com efeito, dentre outros aspectos, não se consegue identificar um Marx "feuerbachiano", desde o início, pois, no caso de Marx, a crítica da religião é o pressuposto de toda a crítica tanto porque põe o homem como o verdadeiro sujeito, criador da própria religião, como porque direciona a crítica para o mundo real que produz a religião. Trata-se, aqui, de um passo fundamental, isto é, "indo além de Feuerbach, Marx desloca-se para o campo da política, entendendo que 'a luta contra a religião é, indiretamente, a luta contra esse mundo que lhe dá seu aroma espiritual" (FREDERICO, 1995, p. 103), configurando, assim, uma crítica do modo de ser dos homens que demanda a religião (reafirmando o caráter ontológico explicitado anteriormente com o exemplo da crítica da política): "Totalmente ao contrário da filosofia alemã, que desce do céu à terra, aqui se eleva da terra ao céu” (MARX; ENGELS, 2007, p. 94). Isto é, "este Estado e esta sociedade produzem a religião, uma consciência invertida do mundo, porque eles são um mundo invertido. /.../. [a religião] É a realização fantástica da essência humana, porque a essência humana não possui verdadeira realidade" (MARX, 2005, p. 145), de modo que "a crítica do céu transforma-se deste modo em crítica da terra, a crítica da religião em crítica do direito, e a crítica da teologia em crítica da política” (MARX, 2005, p. 146). O filósofo argentino Atilio Boron (2003, p. 78) ressalva exatamente este aspecto: "para o jovem Marx, não bastava portanto, afirmar que o homem cria seu Deus, mas era necessário dizer por que procede de tal modo, e como o faz". Temos aqui, por conseguinte, o próprio fundamento da crítica da política (e, mesmo, da economia política, como igualmente atenta Boron ${ }^{101}$ ), elemento que desdobraremos no próximo tópico deste capítulo. Por enquanto, é importante reter o desdobramento dessa crítica em direção à filosofia hegeliana em geral - o que, de todo modo, confirma seu núcleo essencial, o caráter ontológico, a refutação do ser abstrato, puramente pensante que fundamenta esta filosofia (e de seus epígonos neohegelianos).

Um comentário de Quaini, dos poucos geógrafos que se imiscuiram em tal problemática, nos permite problematizar um pouco mais esta questão, retornando à questão da viragem ontológica que caracteriza o pensamento marxiano nesse momento:

\footnotetext{
101 "Da mesma maneira, tampouco Marx se contentava apenas em inverter a relação Estado/sociedade civil postulada por Hegel, dando assim início a um programa de crítica teórica e prática ao qual se dedicaria o resto de sua vida e que, como vimos antes, ficou inacabado" (BORON, 2003, p. 78-9).
} 
O confronto com a filosofia hegeliana (com aquela que mais tarde Marx definirá como sendo a 'sua anterior consciência filosófica') é conduzido contra seu núcleo central, a lógica e o método especulativo, como contra suas aplicações enciclopédicas, a filosofia da religião, do direito, a filosofia da história, da natureza etc (QUAINI, 1979, p. 38).

Objeto reconhecidamente complexo, a crítica de Marx a Hegel é abordada por Quaini a partir do método da construção especulativa tal como exposto por Marx e Engels na obra A sagrada família. Uma reserva deve-se fazer acerca desse comentário de Quaini - o ponto de partida epistemológico que encontra na lógica ou no método especulativo o núcleo central da contraposição de Marx a Hegel. Isto é, mesmo "Feuerbach não centra sua crítica à especulação hegeliana na denúncia de um erro de método, mas sim na falsidade da determinação ontológica em que o método está assentado" (ENDERLE, 2000, p. 24).

Mais ainda para o caso de Marx, que supera, como veremos, o puro empirismo de Feuerbach. A nosso ver, a partir da relação da crítica da filosofia especulativa com as críticas à religião (seu pressuposto) e política (simultânea, no caso de Marx) podemos apanhar seu núcleo central - a questão ontológica. E esse passo - o direcionamento da crítica da alienação religiosa à filosofia especulativa de Hegel numa perspectiva ontológica -, em realidade, como alertamos com Chasin momentos atrás, é dado por Feuerbach (1988, p. 20), que, no seu opúsculo "Teses provisórias para a reforma da filosofia”, de grande influência nos momentos iniciais do pensamento marxiano ${ }^{102}$, afirma peremptoriamente: "o método da crítica reformadora da filosofia especulativa em geral não se distingue do já aplicado na filosofia da religião. Temos apenas de fazer sempre do predicado o sujeito e fazer do sujeito o objeto e princípio" - trata-se, portanto, de uma

${ }^{102}$ A respeito da virada ontológica que caracteriza o pensamento de Marx nesse momento, Chasin (2009, p. 55) afirma: "A grande mudança irrompeu somente com a 'revisão da filosofia do direito de Hegel', instigada por suas poderosas influências: o irresoluto desafio teórico encravado pelos 'interesses materiais' e os lineamentos feuerbachianos contidos em dois textos publicados exatamente à época: 'Teses provisórias para a reforma da filosofia', escritas em abril de 1842, mas só publicadas nos Anedoctis em fevereiro de 1843, e Princípios da filosofia do futuro, editados em julho daquele mesmo ano". Outro destacado estudioso da obra marxiana igualmente destaca a importância deste opúsculo: "Tanto a Crítica da Filosofia Hegeliana quanto A Essência do Cristianismo - na qual se 'inverte' a colocação da religião - subjazem à reflexão de Kreuznach, embora se deva ressaltar, da influência feuerbachiana, os influxos das Teses provisórias para uma Reforma da Filosofia (1843): Marx, logo que lê esta obra, manifesta o seu acordo com um dos seus eixos, a sistemática denúncia da falsa relação estabelecida por Hegel entre sujeito e predicado" (NETTO, 1983, p. 184). De outro lado, porém, cabe ressalvar, junto com José Paulo Netto, que não se pode exacerbar, a ponto de ser considerada única e exclusiva, a influência de Feuerbach nestes textos, não apenas porque Marx sempre resguardou certa originalidade, mas também pela percepção da presença de diferentes fontes filosóficas, ainda que menos expressas, de seu pensamento (como outros autores da época ou mesmo filósofos do porte de Aristóteles) "que mostram o quanto ele [Marx] é tributário do processo de dissolução do hegelianismo e o quanto a sua intervenção se insere num movimento maior, mais abrangente, que envolvia toda a intelectualidade alemã, de oposição ou que se defrontava polemicamente com Hegel" (NETTO, 1983, p. 187). 
questão acerca do ser, do que as coisas são objetivamente. O mesmo "método" - a inversão entre sujeito e predicado, e não qualquer formulação a priori de uma subjetividade descarnada, como posteriormente se entenderá tal termo - da "crítica reformadora" da religião pode, e deve, ser aplicado à filosofia especulativa na medida em que "o segredo da filosofia especulativa é a teologia - a teologia especulativa que se distingue da teologia comum, porque transpõe para o aquém, isto é, actualiza, determina e realiza a essência divina, que a outra exilava para o além, por medo e estupidez" (FEUERBACH, 1988, p. 21).

No caso específico da filosofia hegeliana, identifica ainda o mesmo Feuerbach, temos o pensamento convertido em sujeito, isto é, o predicado (o pensamento) de um sujeito (o "Homem" - por isso, não sendo, inicialmente, de um ser transcendente, mas trazido do além, ou melhor, transposto para o aquém) é convertido (idealmente) na "teologia especulativa" em verdadeiro e efetivo sujeito, determinante. De modo que, ao invés de um sujeito transcendental (Deus), temos o próprio pensamento transcendente: "a essência da lógica de Hegel é o pensamento transcendente, o pensamento do homem posto fora do homem" (FEUERBACH, 1988, p. 21). Estamos, assim, de volta ao "antigo ponto de vista da teologia" já que passamos "a tomar o espírito absoluto por um outro espírito, diferente do ser humano, isto é, como um fantasma de nós mesmos existindo fora de nós" (FEUERBACH, 1988, p. 22). Portanto, estamos de novo no campo da alienação: "ao fundar todo o seu sistema nestes actos de abstracção, a filosofia hegeliana alienou o homem de si mesmo" (FEUERBACH, 1988, p. 22); o que permite, enfim, asseverar que: "a doutrina hegeliana de que a natureza é a realidade posta pela ideia é apenas a expressão racional da doutrina teológica, segundo a qual a natureza é criada por Deus, o ser material por um ser imaterial, isto é, um ser abstracto” (FEUERBACH, 1988, p. 31).

Do vigoroso pensamento de Feuerbach, uma verdadeira revolução teórica ${ }^{103}$, retém-se, ainda, um momento afirmativo: "de Feuerbach data, em primeiro lugar, a crítica positiva humanista e naturalista" (MARX, 2004, p. 20). Constitui-se, na realidade, em dois momentos afirmativos dessa revolução teórica que cabe agora explicitar e, ademais, identificar (inclusive sua superação) no pensamento de Marx: a objetividade do ser e o

103 “.../ quanto menos ruidosas, tanto mais segura, profunda, extensa e duradoura é a eficácia” de seus escritos, "os únicos nos quais - desde a Fenomenologia e a Lógica de Hegel - se encerra uma efetiva revolução teórica" (Karl MARX, 2004, p. 20). 
pensamento como apreensão da lógica dessa objetividade. Em outros termos, tratam-se de

seus reclamos por uma nova ontologia de orientação radicalmente distinta, ou seja, de pronunciada inclinação imanentista-naturalista, cuja relevância, no impulso a novos rumos filosóficos (evidentes, por sinal, no século XX), independe da precariedade e contraditoriedade da polimorfia errática dos encaminhamentos, desfechos e irresoluções de seu próprio trabalho (CHASIN, 2009, p. 41) $)^{104}$.

Também Adam Schaff (1967, p. 59), igualmente apontando para os limites do pensamento feuerbachiano, identifica sua centralidade, na medida em que, ainda que

\begin{abstract}
violentamente criticado por Marx, por seu estreito naturalismo, que não abrangia a História, desempenhava um papel capital na evolução do materialismo, na ocasião, em virtude de sua guinada radical, da antropologia teocêntrica para a antropocêntrica e, a seguir, também para uma visão filosófica do mundo.
\end{abstract}

Com efeito, temos em Feuerbach que "a verdadeira relação entre pensamento e ser é apenas esta: o ser é o sujeito, o pensamento o predicado. O pensamento provém do ser, mas não o ser do pensamento. O ser existe a partir de si e por si - o ser é só dado pelo ser" (FEUERBACH, 1988, p. 31): a antropologia antropocêntrica que, ao substituir, a antropologia teocêntrica - que parte do homem mas o considera predicado do pensamento autonomizado em sujeito - assenta a tese de que "o ponto de partida da filosofia seria o homem vivo, o indivíduo de carne e osso, uma parte da natureza" (SCHAFF, 1967, p. 58) - sujeito sensível, e não mais um "puro eu” pensante, um ser abstrato e indeterminado.

\title{
2.1.1. A PRIORIDADE DA OBJETIVIDADE
}

Os lineamentos da crítica à especulação comportam, assim, uma consequente "reorientação ontológica”, isto é, “a inflexão ontológica rumo à concepção da objetividade do ser". Como vimos grifando, implica na crítica e refutação do "puro eu pensante", fundamento da filosofia especulativa e afirmação do sujeito sensível, como

${ }^{104}$ Georg LUKÁCS (1979, p. 13) igualmente reconhece o posicionamento sempre crítico de Marx em relação a Feuerbach: "O juízo de Marx sobre Feuerbach, portanto, tem um duplo caráter: o reconhecimento de sua virada ontológica como o único ato filosófico sério desse período; e, ao mesmo tempo, a constatação de seus limites, ou seja, do fato de que o materialismo alemão feuerbachiano ignora completamente o problema da ontologia do ser social" 
assevera Chasin, acerca da obra marxiana que manifesta de maneira mais direta (além dos próprios Manuscritos) a influência de Feuerbach:

a condenação da ideia, da ideia pura, da ideia abstrata, da ideia lógica, da ideia como sujeito, que, por mais sutis e elaborados que sejam os seus volteios, é incapaz de reproduzir a peculiaridade concreta dos objetos reais, bem como a exigência de que o conhecimento seja exatamente essa força reprodutora das entidades efetivas, é constante e taxativa por toda a 'Crítica de Kreuznach' (CHASIN, 2009, p. 73).

Presente nessa citação é a compreensão de que a filosofia especulativa, enquanto inversão determinante-determinado, termina por obstaculizar a efetiva compreensão dos objetos, seres e relações sobre os quais se debruça, isto é, recai no misticismo. Aqui sim, então, alcançamos a dimensão epistemológica, alçada ao primeiro plano por Quaini momentos atrás. Temos, então, duas dimensões que explicitam a prioridade $d a$ objetividade no pensamento marxiano: no que se refere ao ser (ao entendimento da objetividade como dado primeiro de todo tipo de entidade) e ao conhecimento (enquanto forma de apreender e reprodução da legalidade da objetividade). Vejamos essas duas dimensões, reconhecendo a prioridade da primeira.

Estes dois aspectos depreendem-se, com traços peculiares, do pensamento feuerbachiano. Nos termos de Feuerbach, “o ser só pode derivar-se do pensamento onde se rompeu a verdadeira unidade de pensamento e ser" (FEUERBACH, 1988, p. 32), isto é, apenas ao romper a unidade presente no real, no caso entre ser e pensamento e, portanto, deturpar o próprio real, pelo pensamento, por abstração, que se pode projetar como um ser o que é predicado: "primeiro se tirou por abstracção ao ser a sua alma, a sua essência e, em seguida, logo se reencontra nesta essência abstraída do ser o sentido e o fundamento deste ser vazio por si mesmo" (FEUERBACH, 1988, p. 32). E temos ainda em Feuerbach, em contraposição ao procedimento especulativo, a defesa rigorosa de que "a filosofia é o conhecimento do que é. Pensar e conhecer as coisas e os seres como são - eis a lei suprema, a mais elevada tarefa da filosofia” (FEUERBACH, 1988, p. 26). Trata-se, com efeito, do imanentismo, destacado por Chasin, transparente na nova filosofia proposta por Feuerbach, na qual, de outro lado, "somos conduzidos a uma ontologia empirista que quer substituir o trânsito do abstrato para o concreto, o processo dialético de constituição dos seres pela exigência de partir do concreto, daquilo que se opõe ao pensamento" (FREDERICO, 1995, p. 30). Este intento, de orientar o pensamento pelo "ser empírico dado de uma vez por todas, determinado" (FREDERICO, 1995, p. 30), desemboca, no caso de Feuerbach, na afirmação da intuição em contraposição ao pensamento: "o homem 
deve procurar a verdade por meio da intuição sensível aberta para o mundo e não pelos exercícios estéreis de um pensamento que gira em falso dentro de seus limites"; e, por via de consequência, na afirmação de um naturalismo (igualmente destacado por Chasin e que o diferencia originariamente do pensamento marxiano, daí mais um aspecto de não podermos falar de um Marx feuerbachiano), dado que "a nova filosofia, guiada pela intuição sensível, deseja uma verdade sem contradição, uma verdade imediata alheia ao intrincado movimento de auto-afirmação do ser, tal como aparece na sequência interminável de sucessivas figuras na filosofia hegeliana" (FREDERICO, 1995, p. 31). Enfim, dê-se a devida ênfase, nesse momento, que "contra o império da razão que se realiza no tempo, Feuerbach reivindica a necessidade de uma filosofia centrada na exaltação do conhecimento imediato fornecido pelos sentidos" (FREDERICO, 1995, p. 32), posição que em texto algum pode depreender-se de Marx, mesmo quando mais se aproxima de Feuerbach.

Com efeito, mediando para Marx, vê-se a refutação da ideia como sujeito associada simultaneamente com afirmação da nova ontologia - radicalmente assentada na objetividade ${ }^{105}$ como fundamento último da realidade - e do pensamento como reprodução teórica, na forma de abstrações das coisas, como adiantamos antes com Chasin. Em primeiro lugar, assim, temos a crítica à filosofia especulativa hegeliana como uma transposição para o aquém do princípio divino, isto é, ao fato de "Hegel autonomiza os predicados e logo os transforma, de forma mística, em seus sujeitos” (MARX, 2005, p. 44), e, em segundo lugar, a contestação definitiva, sob radical critério ontológico, da especulação enquanto método científico. Basta uma rápida observação das duas primeiras das Teses Ad Feuerbach, de1845, notas associadas à redação d'A ideologia alemã (portanto, já no processo de crítica ao próprio Feuerbach), como ilustração de como, o que pode ser reconhecida como uma prioridade epistemológica da objetividade (vista corretamente por Quaini como a refutação da lógica e da metodologia especulativa hegelianas), radica, em Marx, da sua prioridade no ser, isto é, da identificação do ser à objetividade. Em primeiro lugar, isto é, na tese 1, temos a crítica à noção mesma de objeto, realidade, sensível em Feuerbach que, numa palavra, "não apreende a própria atividade humana como atividade objetiva" (MARX; ENGELS, 2004, p. 533), não apreende a realidade enquanto atividade humana sensível - ou seja, temos aqui uma dimensão

\footnotetext{
${ }^{105}$ Ainda que a concepção mesma de objetividade seja logo alçada a um novo plano, enquanto objetividade social, a partir e pelo reconhecimento da centralidade da atividade sensivel na conformação do mundo humano. Sobre tal avanço, dedicamos o tópico 3 deste capítulo.
} 
ontológica, a respeito do ser da realidade concreta como ressaltam os substantivos apontando para a coisidade do mundo. Para então, em segundo lugar, na segunda tese, inserir uma questão propriamente epistemológica, "a questão de saber se ao pensamento humano cabe alguma verdade objetiva" (MARX; ENGELS, 2004, p. 533) que, de todo modo, Marx "resolve" ressaltando a dimensão do ser, a dimensão prática: "é na prática que o homem tem de provar a verdade, isto é, a realidade e o poder, a natureza citerior de seu pensamento" (MARX; ENGELS, 2004, p. 533); refutando-a, na realidade, enquanto uma questão escolástica. A ordem das considerações, apontamos, é significativa. Tomemos, então, como objeto de consideração, o primeiro aspecto: a recusa do ser abstrato.

Mesmo que Marx já esteja, radicalmente, ultrapassando Feuerbach - tanto pelo direcionamento como pelo objeto de sua crítica -, é ainda deste último, inserindo na nova textura do seu pensamento, que Marx retira o ponto de partida - o sujeito real e sua objetivação. Isto é, para pensarmos o indivíduo, deve-se referir inicialmente à objetividade do corpo ${ }^{106}$, ao "indivíduo compreendido como indivíduo real, de carne e osso, como exemplar da espécie biológica, como parte da natureza. E temos, assim, o primeiro elemento da concepção de Marx do indivíduo, como uma concepção materialista" (SCHAFF, 1967, p. 59), que estará presente em todas as obras a partir da Crítica e se explicitam em distintos graus.

Nos Manuscritos econômico-filosóficos, por exemplo, no exato passo em que, mais uma vez, refuta o idealismo hegeliano, Marx assenta os fundamentos essenciais da ontologia geral, em outros termos, procede à identificação do "pressuposto ineliminável" básico, primeiro: a identificação entre ser e objetividade. Quando reafirma, no espírito da crítica à Ideia pura, abstrata, que "um ser não-objetivo é um não-ser" (MARX, 2004, p. 127), em outros termos, "um ser não objetivo é um ser não efetivo, não sensível, apenas pensado, isto é, apenas imaginado, um ser da abstração” (MARX, 2004, p. 128), assinala imediatamente: "Ser sensível, isto é, ser efetivo, é ser objeto do sentido, ser objeto sensivel, e, portanto, ter objetos sensíveis fora de si, ter objetos de sua sensibilidade. Ser sensível é ser padecente" (MARX, 2004, p. 128). Mais ainda, em realidade, "Marx, contrapondo-se à especulação, não apenas identifica ser à objetividade, mas também procura demarcar o caráter relacional da mesma, vale dizer, da constante interação

${ }^{106}$ Dimensão que, por vezes, é confundida com um pretenso economicismo na obra de Marx. 
objetivamente existente entre seres efetivos enquanto tais, ressaltando ao final o seu caráter de padecimento ou seja, de carecimento do outro" (VAISMAN, 1999, p. 248).

Poder-se-ia dizer, por esse passo, que, em Marx, natureza corresponde ao ser em geral - no qual, portanto, o homem se insere - e se identifica à objetividade relacional, à sensibilidade, ao padecimento, ao carecimento de seres exteriores. É o que se pode depreender, por exemplo, da argumentação de que o homem enquanto "ser objetivo atua objetivamente e não atuaria objetivamente se o objetivo não estivesse posto em sua determinação essencial. Ele cria, assenta apenas objetos, porque ele é assentado mediante esses objetos, porque é, desde a origem, natureza" (MARX, 2004, p. 126-7). Ou seja, por ser um ser natural objetivo, corpóreo, o homem necessita de seres objetivos para manifestar a sua existência e, nesse processo, assenta, cria, põe outros objetos.

Num longo trecho que vem à seguir da última citação, Marx reafirma e desdobra sua argumentação partindo do reconhecimento peremptório da naturalidade do homem:

O homem é imediatamente ser natural. Como ser natural, e como ser natural vivo, está, por um lado, munido de forças naturais, de forças vitais, é um ser natural ativo; estas forças existem nele como possibilidades e capacidades, como pulsões; por outro, enquanto ser natural, corpóreo e sensível, objetivo, ele é um ser que sofre, dependente e limitado, assim como o animal e a planta, isto é, os objetos de suas pulsões existem foram dele, como objetos independentes dele. Mas esses objetos são objetos de seu carecimento, objetos essenciais, indispensáveis para a atuação e a confirmação de suas forças essenciais. Que o homem é um ser corpóreo, dotado de forças naturais, vivo, efetivo, objetivo, sensível significa que ele tem objetos efetivos, sensíveis como objeto de seu ser, de sua manifestação de vida, ou que ele pode somente manifestar sua vida em objetos sensíveis efetivos. É idêntico: ser objetivo, natural, sensível e ao mesmo tempo ter fora de si objetos, natureza, sentido, ou ser objeto mesmo, natureza, sentido para um terceiro. A fome é uma carência natural; ela necessita, por conseguinte de uma natureza fora de si, para se satisfazer, para se saciar. A fome é a carência confessada de meu corpo por um objeto existente fora dele, indispensável à sua integração e externação essencial. O sol é o objeto da planta, um objeto para ela imprescindível, confirmados de sua vida, assim como a planta é objeto do sol, enquanto externação da força evocadora de vida do sol, da força essencial objetiva do sol (MARX, 2004, p. 127).

Vê-se, então, o "reconhecimento da objetividade como categoria primária de toda entificação" (COSTA, 2001, p. 168): ser natural implica em ser corpóreo, sensível, numa palavra, objetivo, tal qual é o homem, um ser corpóreo, dotado de forças naturais, vivo, efetivo, objetivo, sensível. Enquanto tal, padece, necessita de outras objetividades para atuar, para confirmar a si próprio, isto é, para confirmar suas forças naturais, vitais, suas possibilidades e capacidades, pulsões. "Ou seja, o caráter objetivo do ser do homem se expressa na necessidade que ele tem de objetividades exteriores" (VAISMAN, 1999, p. 128). Como assenta o próprio Marx em outro trecho: "o homem enquanto ser objetivo 
sensível é, por conseguinte, um padecedor, e, porque é um ser que sente o seu tormento, um ser apaixonado" (MARX, 2004, p. 128).

O que pretendemos, nesse momento, demarcar é a identificação entre ser, natureza e objetividade nos textos marxianos analisados, enquanto dimensão do próprio ser social, isto é, Marx tão-somente "verifica o caráter material dos indivíduos humanos":

\footnotetext{
Como todos os seres naturais vivos, os indivíduos humanos também resultam do desdobrar-se das formas naturais, do movimento evolutivo da vida, do qual eles herdam, por assim dizer, uma determinada estrutura corpórea, dotada de atributos e necessidades, e um ambiente natural externo, com o qual forçosamente têm de se pôr em relação para manter suas próprias vidas (TEIXEIRA, 1999, p. 179).
}

Antes vimos que, enquanto seres naturais, os homens estão munidos de forças vitais e, simultaneamente, padecem de seres que estão fora deles - que compõem o ambiente natural externo. E n'A ideologia alemã o argumento é reforçado, em toda a sua radicalidade. Iniciando pela reposição do correto ponto de partida - estabelecido a partir da Crítica de Kreuznach, desdobrado nos Manuscritos de 1844 e que será reafirmado anos depois, no aludido "Prefácio":

\begin{abstract}
A estrutura social e o Estado provêm constantemente do processo de vida de indivíduos determinados, mas desses indivíduos não como podem aparecer na imaginação própria ou alheia, mas sim como realmente são, quer dizer, tal como atuam, como produzem materialmente e, portanto, tal como desenvolvem suas atividades sob determinados limites, pressupostos e condições materiais, independentes de seu arbítrio (MARX; ENGELS, 2007, p. 93).
\end{abstract}

Ao tempo que referenda a inversão da relação Estado-sociedade, em relação à filosofia hegeliana, Marx assenta a objetividade da vida individual como dado preliminar - da própria vida e, por conseguinte, para o pensamento que a pretende refletir. Em suma, Marx reafirma a posição ontológica que o caracteriza a partir da crítica à filosofia especulativa de Hegel, na medida em que visa apreender os indivíduos determinados tal como eles realmente são, isto é, tal como produzem materialmente sua vida. E produzem materialmente a sua vida, pois são, de início, matéria, em outros termos: "o primeiro pressuposto de toda a história humana é, naturalmente, a existência de indivíduos humanos vivos. O primeiro fato a constatar é, pois, a organização corporal desses indivíduos e, por meio dela, sua relação dada com o restante da natureza" (MARX; ENGELS, 2007, p. 87).

Ou seja, do caráter objetivo e relacional de todo o ser advém, por via de consequência, a centralidade da satisfação das necessidades materiais na constituição da própria história, isto é, o fato de que 
O primeiro ato histórico é, pois, a produção dos meios para a satisfação dessas necessidades, a produção da própria vida material, e este é, sem dúvida, um ato histórico, uma condição fundamental de toda a história, que ainda hoje, assim como há milênios, tem de ser cumprida diariamente, a cada hora, simplesmente para manter os homens vivos (MARX; ENGELS, 2007, p. 33).

Enfim, "Marx situa o ser ativo como entificação peculiar que transcende os limites naturais, pois é capaz de se pôr como uma objetividade sensível que apresenta atributos específicos" (COSTA, 2001, p. 169), que, ademais, já haviam sido comentados nos trechos anteriores de Marx; quando assinala, por exemplo, que, padecedor como qualquer ser objetivo, o homem sente o seu tormento, é, portanto, um ser apaixonado. O reconhecimento efetivo dessas especificidades, porém, implicam na superação definitiva de Feuerbach (a partir do entendimento, já adiantado anteriormente, da objetividade social). Cabe, então, antes desse passo decisivo, apreender o segundo aspecto (derivado deste primeiro, da identificação entre ser e objetividade) do pensamento marxiano, no qual desde o início já o afasta de Feuerbach - a filosofia como apreensão teórica do ser. Em suma, enquanto este valorizava a intuição e exaltava os sentidos, Marx, de pronto, diferencia-se por indicar o papel do pensamento e das abstrações na reprodução do mundo.

Com efeito, Marx anota, logo no início de sua Crítica da filosofia do direito de Hegel que, na obra deste, “a assim denominada 'Ideia real' (o Espírito como infinito, real) é, portanto, apresentada como se ela agisse segundo um princípio determinado, mediante um desígnio determinado" (MARX, 2005, p. 29). Refere-se aqui, concretamente, ao fato de que para Hegel o Estado se divide em família e sociedade civil - estas "são apreendida como esferas conceituais do Estado e, com efeito, como esferas de sua finitude" (MARX, 2005 , p. 29) ${ }^{107}$. De modo que, em realidade, a Ideia, no caso transmutada como Estado, "se divide em esferas finitas e o faz 'para a si retornar, para ser para si'; ela o faz de um modo que é precisamente como é na realidade" (MARX, 2005, p. 29). Numa palavra, enfim: "aqui aparece claramente o misticismo lógico, panteísta" e isto porque, supondo como determinante a lógica da Ideia ${ }^{108}$, “a empiria ordinária não tem como lei o seu próprio espírito, mas um espírito estranho e, ao contrário, a Ideia real tem como sua existência não uma realidade desenvolvida a partir dela mesma, mas a empiria ordinária, comum” (MARX, 2005, p. 29-30). Tendo uma lógica, um espírito, estranho à própria

\footnotetext{
${ }^{107}$ Perceba-se, de passagem, como o objeto da crítica marxiana é, já, a política, o Estado, distintamente de Feuerbach. Retomaremos o conteúdo efetivo dessa discussão no próximo tópico deste capítulo.

108 “A Ideia é feita sujeito, na medida em que a ela é conferido o poder de engendrar, a partir de si mesma, suas determinações concretas, finitas" (Rubens ENDERLE, “Apresentação”, p. 19).
} 
empiria, a relação real se inverte na especulação: “família e sociedade civil são os pressupostos do Estado; elas são os elementos propriamente ativos; mas, na especulação, isso se inverte" (MARX, 2005, p. 30). Posição que é reafirmada e desdobrada ao longo do texto: "elas são a força motriz. Segundo Hegel, ao contrário, elas são produzidas pela Ideia real” (MARX, 2005, p. 30); “o fato é que o Estado se produz a partir da multidão, tal como ela existe na forma dos membros da família e dos membros da sociedade. A especulação enuncia esse fato como um ato da Ideia, não como a ideia da multidão, senão como o ato de uma ideia subjetiva e do próprio fato diferenciada" (MARX, 2005, p. 31).

Note-se, nessa última citação, a sutil distinção entre a Ideia - uma ideia subjetiva e do próprio fato diferenciada - e a ideia da multidão - dos membros da família e da sociedade civil, tal como eles pensam. Arguta distinção que é desdobrada por Marx e Engels em diversos momentos de sua crítica aos neo-hegelianos. Por exemplo, quanto à ideia da multidão pode-se lembrar que "a consciência não pode jamais ser outra coisa do que o ser consciente, e o ser dos homens é o seu processo de vida real" (MARX; ENGELS, 2007, p. 94). Ou então, na famosa passagem:

Não é a consciência que determina a vida, mas a vida que determina a consciência. No primeiro modo de considerar as coisas, parte-se da consciência como do indivíduo vivo; no segundo, que corresponde à vida real, parte-se dos próprios indivíduos reais, vivos, e se considera a consciência apenas como sua consciência (MARX; ENGELS, 2007, p. 94).

Quanto à noção de que a consciência determina a vida, poder-se-ia remeter à Ideia, tomada como ser, à consciência como indivíduo vivo. Quanto ao ponto de partida correto, mais adequado - basta considerar a realidade, a vida real. Em suma, tem-se, para relembrar Feuerbach, o rompimento da unidade real entre o ser e o pensamento e a conversão deste num princípio determinante, numa lógica produtora do real.

E, nisto,

O fato, saído da existência empírica, não é apreensível como tal, mas como resultado místico. O real torna-se fenômeno; porém, a Ideia não tem outro conteúdo a não ser esse fenômeno. Também não possui a Ideia outra finalidade a não ser a finalidade lógica: 'ser espírito real para si infinito'. Nesse parágrafo, encontra-se resumido todo o mistério da filosofia do direito e da filosofia hegeliana em geral (MARX, 2005, p. 31).

Marx reafirma e desdobra essa crítica ao mistério da filosofia hegeliana em geral em diversos momentos de sua trajetória filosófica e com vistas a variados objetos e objetivos, como já vimos com Quaini. No texto que analisamos, o objeto precípuo é a política - com a característica de ser a primeira na qual se manifesta. E é na política que Marx identifica o caráter da filosofia hegeliana em geral - seu feitio místico, panteísta. 
Em seus termos, “o 'fim do Estado’ e os 'poderes do Estado' são mistificados, visto que são apresentados como 'modos de existência' da 'Substância' e aparecem como algo separado de sua existência real" (MARX, 2005, p. 31). Vemos, então, o mesmo tipo de crítica sendo desdobrado, que tem como primeiro passo "a substantificação ou hipostatização da ideia e a consequente transformação do sujeito real em predicado ou atributo da ideia" (MARX, 2005, p. 31). E o próprio desenvolvimento da realidade empírica torna-se, sacramentando o misticismo, um movimento do pensamento, convertese em lógica.

Tomando como ponto de partida a reflexão de A sagrada família, Quaini explica:

deste modo as diferenças sensíveis que separam uma da outra a maçã, a pera, a amêndoa tornam-se auto-diferenciações 'do fruto' e os frutos particulares são elevados a momentos do processo vital do fruto, a membros distintos de uma totalidade, de uma sucessão organicamente articulada (QUAINI, 1979, p. 39).

Tal qual, ademais, tornara-se a família e a sociedade civil em relação ao Estado: a realidade empírica como diferenciações do conceito puro, da Ideia. Valendo, assim, retornar a Marx: "toda a filosofia do direito [de Hegel] é, portanto, apenas um parêntese da lógica" (MARX, 2005, p. 39):

O conteúdo concreto, a determinação real, aparece como formal; a forma inteiramente abstrata de determinação aparece como o conteúdo concreto. A essência das determinações do Estado não consiste em que possam ser consideradas como determinações do Estado, mas sim como determinações lógico-metafísicas em sua forma mais abstrata. $\mathrm{O}$ verdadeiro interesse não é a filosofia do direito, mas a lógica. $\mathrm{O}$ trabalho filosófico não consiste em que o pensamento se concretize das determinações políticas, mas em que as determinações políticas existentes se volatilizem no pensamento abstrato. $\mathrm{O}$ momento filosófico não é a lógica da coisa, mas a coisa da lógica. A lógica não serve à demonstração do Estado, mas o Estado serve à demonstração da lógica (MARX, 2005, p. 38-9).

Acompanhamos, decerto desdobrando e exemplificando, mais uma vez a crítica ao procedimento especulativo pois, em especial, já se afirma aí uma espécie de momento positivo fundamental da argumentação marxiana: do trabalho filosófico como a apreensão da lógica da coisa ${ }^{109}$, da lógica como a demonstração do objeto, das determinações reais, empíricas desse objeto. Daqui depreende-se, agora metodologicamente, epistemologicamente a prioridade da objetividade, isto é, o objeto, a coisa dada, deve reger o trabalho de investigação, o trabalho filosófico - inclusive, e

\footnotetext{
${ }^{109}$ Diz Quaini (1979, p. 40): “ainda uma vez contraposta à tendência hegeliana e especulativa de encontrar
} em cada determinação concreta as correspondentes determinações abstratas ou do conceito puro". 
fundamentalmente, justifica-se aqui nossa tentativa de acompanhar o movimento mesmo do objeto, isto é, da obra marxiana.

Enquanto o misticismo especulativo, no qual "a Ideia é feita sujeito, as distinções e sua realidade são postas como seu desenvolvimento, como seu resultado", impede a compreensão efetiva dos seres, apaga as diferenças sensíveis, nos termos de Quaini, na medida em que "aqui se fala da Ideia como de um sujeito, da Ideia que se desenvolve em suas distinções" (MARX, 2005, p. 33), o trabalho efetivo da ideia - o trabalho ideal, poder-se-ia dizer"110 - é a compreensão dessas distinções reais, isto é, "pelo contrário, a Ideia deve ser desenvolvida a partir das distinções reais" (MARX, 2005, p. 33), é a determinação ideal das distinções. Desse modo, no procedimento especulativo,

o único interesse é, pura e simplesmente, reencontrar 'a Ideia', a 'Ideia lógica' em cada elemento, seja o do Estado, seja o da natureza, e os sujeitos reais, como aqui a 'constituição política', convertem-se em seus simples nomes, de modo que há apenas aparência de um conhecimento real, pois esses sujeitos reais permanecem incompreendidos, visto que não são determinações apreendidas em sua essência específica (MARX, 2005, p. 34).

Apreendendo as afirmações desse momento negativo, temos que, de outro lado, obtém-se um conhecimento real, se compreende os sujeitos reais, quando as determinações apreendidas pela ideia traduzem sua essência específica - suas distinções em relação aos objetos e sujeitos, donde se deriva que "uma explicação que não dá a differentia specifica não é uma explicação", é um misticismo panteísta. Explicar, portanto, é dar a diferença específica, compreender a especificidade do objeto, o que o diferencia dos demais e o torna singular. De que vale mais um exemplo concreto para reafirmar. Em Hegel, "em lugar do conceito da constituição, obtemos a constituição do Conceito" - mais uma vez percebamos a distinção entre o conceito, a reprodução ideal de um objeto, e o Conceito, sua substantivação em Coisa - "o pensamento não se orienta pela natureza do Estado, mas sim o Estado por um pensamento pronto" (MARX, 2005, p. 40) - e mais uma vez a reafirmação do pensamento como aquele que se orienta pela natureza, se deixa reger, pelo objeto estudado, no caso, o Estado e a constituição, de modo que "Hegel dá à sua lógica um corpo político; ele não dá a lógica do corpo político" (MARX, 2005, p. 67); sendo, então, o pensamento pronto a sua lógica, a que ordena a análise no caso hegeliano e, de outra parte, a tarefa do pensamento resultar na lógica do objeto, como veremos, na lógica específica do objeto específico.

${ }^{110}$ Da ideia, e não da Ideia, grife-se. 
Tem-se aqui explicitado, enfim, o duplo movimento de aproximação e afastamento em relação a Feuerbach. Aproximação no sentido do imanentismo, da orientação pelos objetos e afastamento pela defesa do papel do pensamento, para além da pura intuição. Isto é, (e o caráter sintético justifica a citação integral da passagem)

Preocupado em livrar-se desse logicismo para poder reter a verdade dos seres particulares que haviam sido transferidos para o Estado hegeliano, Marx, bem no espírito da filosofia feuerbachiana, propõe uma ontologia materialista (na verdade empirista), como o caminho certo para escapar às armadilhas do pensamento abstrato automediador que tudo esvazia ao fazer passar para frente a realização do significado dos seres particulares. Mas, ao propor como caminho de pesquisa a descoberta da 'lógica da coisa', afasta-se de Feuerbach para quem a verdade é sinônimo de revelação que se descortina à experiência imediata. O caráter mediado da verdade - a ser descoberta no autodesenvolvimento da 'coisa' - de novo reaproxima Marx de Hegel e anuncia a posterior disposição de estender a dialética do campo abstrato do pensamento lógico para o coração da matéria social (FREDERICO, 1995, p. 60).

Alcançamos assim, enfim, a própria definição marxiana de crítica ontológica ou, em seus termos, verdadeiramente filosófica que se diferencia radicalmente da

crítica dogmática, que luta contra seu objeto, do mesmo modo como, antigamente, o dogma da santíssima trindade era eliminado por meio da contradição entre um e três. A verdadeira crítica, em vez disso, mostra a gênese interna da santíssima trindade no cérebro humano. Descreve seu ato de nascimento. Com isso, a crítica verdadeiramente filosófica da atual constituição do Estado não indica somente as contradições existentes; ela esclarece essas contradições, compreende sua gênese, sua necessidade. Ela as apreende em seu significado específico. Mas esse compreender não consiste, como pensa Hegel, em reconhecer por toda parte as determinações do Conceito lógico, mas em apreender a lógica específica do objeto específico (MARX, 2005, p. 108).

Trata-se, em essência, do elemento que vimos anteriormente - raiz do passo além de Marx em relação a Feuerbach: não basta explicar a alienação religiosa, ou da filosofia especulativa, ou mesmo a alienação política, como a projeção de determinações dos sujeitos para fora deles, da essência do sujeito como um Ente abstrato, é necessário, também e em especial, compreender as razões, o porquê dessa inversão. É necessário compreender como esse modo de pensar enraíza-se num determinado modo de ser dos homens: este é o cerne da crítica ontológica. Termo ${ }^{111}$ problematizado por José Chasin a fim de designar o procedimento investigativo explicitado e exercitado por Marx a partir do estudo Crítica da filosofia do direito de Hegel.

A crítica filosófica ou ontológica, tal como determinado acima, referencia o procedimento investigativo da análise imanente de um dado objeto e a compreensão de

\footnotetext{
${ }^{111}$ Já utilizado, por exemplo, por G. LUKÁCS (1979, p. 27).
} 
sua gênese e necessidade social. Por análise imanente deve-se remeter à busca da lógica interna e específica do objeto, seu significado específico (a lógica específica do objeto específico), ou seja, “a pesquisa deve 'apropriar-se detalhadamente' da matéria, isto é, do objeto estudado; deve analisá-lo e descobrir as relações internas de seus elementos entre si. O método de análise deve convir ao objeto estudado" (LEFEBVRE, 2009, p. 31). Enquanto a compreensão da gênese e da necessidade envolve a apreensão de seus liames com uma situação histórico-concreta do ser social, sua vinculação específica com um modo de ser dos homens. Em outros termos,

a 'crítica verdadeira' ascende à decifração da mundaneidade imperfeita em sua realidade, para esclarecê-la, compreendendo sua gênese e necessidade, ou seja, para captura-la em seu significado próprio, por meio da determinação das lógicas específicas que atualizam os objetos em seu multiverso (CHASIN, 2009, p. 74).

Por outros caminhos, o filósofo argentino Atilio Boron (2003, p. 78) igualmente identifica o caráter ontológico da crítica marxiana (no caso, a crítica da religião) ao registrar que "para o jovem Marx, não bastava, portanto, afirmar que o homem cria seu Deus, mas era necessário dizer por que procede de tal modo, e como o faz". Nos termos que se apreendem de Marx, compreender a gênese - o "como"; e a necessidade - o "por que". De acordo com o próprio Marx (2005, p. 146), é aqui que "a crítica do céu transforma-se deste modo em crítica da terra, a crítica da religião em crítica do direito, e a crítica da teologia em crítica da política". Ou seja, a crítica da religião (enquanto fantasia ou consolo, ou "o suspiro da criatura oprimida"), em Marx, é o primeiro passo da crítica ao mundo que necessita da religião:

A abolição da religião enquanto felicidade ilusória dos homens é a exigência de sua felicidade real. O apelo para que abandonem as ilusões a respeito da sua condição é o apelo para abandonarem uma condição que precisa de ilusões. A crítica da religião é, pois, o germe da crítica do vale de lágrimas, do qual a religião é a auréola (MARX, 2005, p. 151).

Em suma, noutra passagem esclarecedora: "Este Estado e esta sociedade produzem a religião, uma consciência invertida do mundo, porque eles são um mundo invertido" (MARX, 2005, p. 151). Pretendemos desdobrar mais adiante esta questão, mas fica aqui, de saída, registrado o fundamental - o fato de que, para Marx, por exemplo, a crítica que realizava à teoria hegeliana do Estado, a primeira de suas críticas ontológicas, era, igualmente, na medida em que esta teoria refletia concretamente a realidade, uma crítica ao próprio Estado moderno e à organização social que o engendra: "a crítica da filosofia alemã do direito e do Estado, que teve a mais lógica, profunda e completa expressão em Hegel, surge ao mesmo tempo como análise crítica do Estado moderno e 
da realidade a ele associada /.../" (MARX, 2005, p. 151). Na medida em que a filosofia alemã correspondia à consciência teórica da política moderna "o status quo da ciência política alemã exprime a imperfeição do Estado moderno em si, a degenerescência da sua carne” (MARX, 2005, p. 151). E assim se inicia um trajeto crítico que resta inacabado a compreensão da realidade associada ao Estado moderno, a sociedade burguesa, cuja anatomia deve ser encontrada, como sabido, na economia política.

Com efeito, exatamente a não percepção do arrimo de uma concepção filosófica em sua base social é uma das críticas (a fundamental, diria José Paulo Netto) de Marx e Engels aos neo-hegelianos, aos "ideólogos alemães": "A nenhum desses filósofos ocorreu a ideia de perguntar sobre a conexão entre a filosofia alemã e a realidade alemã, sobre a conexão de sua crítica com seu próprio meio material" (MARX; ENGELS, 2007, p. 84). Enfatizando, ainda, na sequência, que "a produção de ideias, de representações, da consciência, está, em princípio, imediatamente entrelaçada com a atividade material e com o intercâmbio material dos homens, com a linguagem da vida real" (MARX; ENGELS, 2007, p. 93) de modo que "se, em toda a ideologia, os homens e suas relações aparecem de cabeça para baixo como numa câmara escura, este fenômeno resulta de seu processo histórico de vida" e, assim, "também as formulações nebulosas na cabeça dos homens são sublimações necessárias de seu processo de vida material, processo empiricamente constatável e ligado a pressupostos materiais" (MARX; ENGELS, 2007, p. 84).

No que se refere, portanto, ao estudo de determinadas formulações teóricas, a crítica ontológica ou filosófica implica tanto o exame dessa dada forma de compreensão da realidade social (de seu significado específico) como do modo de ser dos homens no qual essa forma radica, a individuação que a engendra. Pretendemos, então, esclarecer as contradições imanentes às concepções do homem da ciência geográfica, contribuindo para a compreensão de sua gênese e de sua necessidade, a partir da interlocução com a concepção do homem na ontologia marxiana - constituída no mesmo contexto histórico e geográfico. Ou então, se a Geografia Moderna configura uma formulação nebulosa acerca do homem e do seu ser, cabe questionar acerca dos seus pressupostos materiais, do modo de ser, isto é, do processo de vida material do qual é a sublimação necessária.

Enfim, trata-se de, ao recusar a autodeterminação do predicado, "partir do sujeito real e considerar sua objetivação" (MARX, 2005, p. 44). É aqui que a crítica do céu se converte em crítica da terra, isto é, a crítica da religião se converte na crítica da sociedade 
que demanda a religião - portanto, em crítica da política e da economia política. Vamos, então, a elas.

\subsection{A CRÍTICA DA POLÍTICA: SOCIALIDADE E DETERMINAÇÃO ONTONEGATIVA DA POLITICIDADE}

Em diversos momentos do tópico anterior tangenciamos questões relativas às demais críticas instauradoras do pensamento marxiano, em especial a crítica da política, devido as demandas do próprio objeto - o que equivale a afirmar, numa palavra, que o pensamento de Marx conforma uma unidade, que aqui analiticamente decompomos, e, portanto, apontar para a vinculação íntima entre a crítica à filosofia especulativa e as críticas da política e da economia política na emergência de uma nova concepção acerca do mundo e do homem ${ }^{112}$. Vimos, inclusive, que a relação entre a sociedade civil e o Estado é, exatamente, um dos eixos de crítica ao misticismo hegeliano ${ }^{113}$. Diferentes pesquisadores apontam, ainda, ao fato de que a crítica da política, em verdade, constitui a primeira efetivada por Marx na medida em que assinala sua motivação essencial - a atuação sociopolítica exercitada no periódico Gazeta Renana - e sua inserção na tradição de reflexão ocidental, que privilegia as dimensões relacionadas à esfera políticoinstitucional da realidade ${ }^{114}$. Com efeito, embora o "passo adiante", no contexto de dissolução do hegelianismo - da crítica da religião para a crítica da filosofia especulativa - tenha sido indicado e, em certa medida, dado por Feuerbach, assentando a objetividade como dimensão inerente ao ser, é apropriado por Marx no interior da crítica da política -

\footnotetext{
112 Qualquer aproximação séria, com efeito, deve respeitar "as duas originalidades principais do pensamento de Marx: de um lado, a unidade de seu trabalho teórico com suas intervenções práticas (uma unidade da teoria com a prática que foi designada algumas vezes pelo conceito de 'filosofia da práxis'); de outro, a imbricação das dimensões filosóficas, econômicas, históricas, sociológicas e políticas de sua teoria (uma dimensão interdisciplinar que podemos considerar essencial a qualquer 'teoria crítica da sociedade')" (RENAULT; DUMÉNIL; LÖWY, 2011, p. 9)

${ }^{113}$ Referendando, assim, por exemplo, Lefebvre (1979, p. 23): “A crítica do Estado e a crítica da filosofia, pois, são feitas em conjunto, através da crítica radical ao sistema filosófico-político".

114 "Que a crítica ontológica tenha incidido, em primeiro lugar, sobre matéria política, é simples decorrência do próprio itinerário pessoal de Marx, vinculado às ênfases e prioridades de um dado tempo e lugar" (CHASIN, 2009, p. 63). Igualmente José Paulo NETTO (1983, p. 180) identifica que "as preocupações de Marx, em 1843, incidiam imediatamente sobre problemas de ordem política - a estância em Kreuznach, paragem entre Colônia e o auto-exílio parisiense, na moldura tranquila da lua-de-mel, permite-lhe um recolhimento aproveitado não só para uma revisão da história antiga (então, redige longas cronologias), mas para leituras sobre a Revolução Francesa (Ranke, Ludwig, Wachsmuth) e, especialmente, dos teóricos da política, da natureza e da estrutura do poder (Maquiavel, Montesquieu e Rousseau)".
} 
e, por conseguinte, envolve a formulação efetiva de seu pensamento, a continuidade no sentido de erigir um pensamento próprio $^{115}$.

Transita-se, como já anunciamos no tópico anterior, da "crítica do céu para a crítica da terra" - trajeto sintetizado e aprofundado num conjunto de artigos redigidos entre o final de 1843 e meados de 1844: "Sobre a questão judaica" e "Crítica da filosofia do direito de Hegel - Introdução", produzidos entre setembro e dezembro de 1843 e publicados em fevereiro de 1844 nos Anais Franco-Alemães ${ }^{116}$, e o texto "Glosas críticas ao artigo 'O rei da Prússia e a reforma social. De um prussiano"”, escrito entre julho e agosto de 1844, voltado contra o mesmo Arnold Ruge, com o qual organizara os Anais, e publicado no periódico Vorwärts! ${ }^{117}$. A estes textos, recuperando alguns elementos dos Manuscritos de Kreuznach, voltamos, agora, nossa atenção.

Nesse sentido, vale reter que, ao discutir especificamente questões de ordem política, Marx insere-se ainda, em realidade, no bojo mesmo da tradicional reflexão ocidental, que entende o Estado como produtor e regulador último da vida social. Ao enfrentar os problemas da vida material em sua experiência na Gazeta Renana, ao abordar

\footnotetext{
115 Inclusive porque "se se diz, portanto, que a Crítica incorpora muito das temáticas e ideias feuerbachianas, para que a afirmação não redunde em erro é necessário dar realce, ao mesmo tempo, ao fato verificável de que, no plano político, ela é também uma polêmica contra Feuerbach" (NETTO, 1983, p. 188-9), na medida em que este pensador representava mesmo um retrocesso em relação a Hegel, no campo da reflexão política, cf. NETTO (1983, p. 188).

${ }^{116}$ Idealizado por Arnold Ruge, este jornal é publicado em Paris, como forma de fugir da censura prussiana. Com seu adoecimento, acaba sendo editado pelo próprio Marx: "Quando por fim saiu o jornal, sob a direção editorial de Marx, a publicação tinha a extensão de um livro e continha poemas de Herwegh e de Heine; uma troca de cartas críticas da Alemanha entre Ruge, Marx, Feuerbach e Bakunin; ensaios de Bakunin, Moses Hess e um antigo editor de jornais expulso da Bavária chamado F. C. Bernays; e dois artigos de Marx e dois de um jovem alemão que vivia na Inglaterra chamado Engels. Mil exemplares foram impressos" (GABRIEL, 2013, p. 83-4). A divulgação desse jornal será extremamente limitada, sendo este seu único número: "não encontrou leitores em Paris e foi barrado na fronteira alemã" (GABRIEL, 2013, p. 84). Mas sua importância é decisiva para Marx, responsável pela guinada radical que inicia seu afastamento em relação a Ruge: ali são publicados dois ensaios que acentuam a atenção de Marx aos problemas econômicos e, como veremos, sobre ele exercem grande influência - "A essência do dinheiro", de Moses Hess (que diversos estudiosos encontram relação direta com a segunda parte de "Sobre a questão judaica") e o "Esboço de uma crítica da economia política", de Engels, texto ao qual Marx faz referências elogiosas anos depois, no próprio $O$ capital.

${ }^{117}$ Financiado por um compositor de óperas em realidade instruído por Frederico Guilherme IV, com o fim de "atrair os alemães rebeldes em Paris dando-lhes espaço editorial por meio do qual eles mesmos haveriam de se enforcar", o "semanário parisiense era conhecido como o único jornal de oposição em alemão que não era censurado em toda a Europa" (GABRIEL, 2013, p. 97). No âmbito da anedota histórica, a participação de Marx nesse semanário proporciona seu segundo contato com os autores da Geografia Moderna (havia sido aluno de Ritter na Universidade de Berlim): em 11 de janeiro de 1845, "o ministro francês do Interior havia expedido uma ordem dando a alguns membros da equipe do Vorwärts! - Marx, Heine, Ruge, Bernays e Bakunin, entre eles - 24 horas para deixar a cidade e um pouco mais do que isso para deixar a França. Luís Filipe I havia sido persuadido a expulsar aqueles 'ateus' pelo famoso cientista prussiano Alexander von Humboldt, que lhe oferecera de presente um raro vaso de porcelana de Frederico Guilherme" (GABRIEL, 2013, p. 109).
} 
o âmbito dos conflitos e contradições sociais e suas repercussões e relações com o poder político institucional, "era a vida mesmo empurrando Marx, do seu terreno profissional originário, da sua 'especialidade', a jurisprudência, para o campo de indagações que, desde Hobbes, pusera-se na ordem do dia da reflexão ocidental: a natureza da sociedade política, com o privilégio do Estado", isto é, complementa o mesmo autor na sequência, "seu objeto, em 1843, obedece à tradição intelectual que se empenha em visualizar a relação entre as instâncias estatais e as demais instituições sócio-políticas" (NETTO , 1983, p. 181). Se o objeto não era propriamente original, se não compunha uma rota especificamente singular de Marx, a resolução que dá às questões, amparado nos fundamentos da filosofia de Feuerbach - em especial o imanentismo e a teoria da alienação -, faculta o rompimento com a referida tradição. Em suma, se "levado a este questionamento, Marx não podia fugir ao confronto com a filosofia do Estado de Hegel” (NETTO , 1983, p. 181), na medida em que "ao contrário de todos os autores do seu universo intelectual, era Hegel quem dava conta do Estado moderno" (NETTO, 1983, p. 181), é neste confronto que assenta as bases originais de seu pensamento.

Ressalte-se, assim, novamente, o caráter ontológico da crítica da política ${ }^{118}$, então delineada em seus traços fundamentais, como demarcado nas palavras de Lívia Cotrim, em pesquisa na qual comprova a manutenção e desdobramento das concepções sobre a politicidade formuladas nesta época por toda a obra marxiana:

a crítica da política (assim como a da especulação e da economia política)
abrange a um tempo uma teoria - uma dada maneira de apreender a realidade
- e a própria realidade apreendida; trata-se, pois, não apenas da crítica da
concepção que tem em Hegel seu expoente máximo, como da crítica à
politicidade mesma; de fato, é esta última que possibilita a primeira (COTRIM,
L., 2007, p. 36$)^{119}$.

Em suma, é o entendimento do mundo, do por-si da politicidade, que faculta a refutação da teoria hegeliana, enquanto apreensão incompleta ou equivocada da lógica essencial do objeto abordado. Em suma, "tratando-se de uma configuração de natureza ontológica, o propósito essencial dessa teoria é identificar o caráter da política, esclarecer sua origem e configurar sua peculiaridade na constelação dos predicados do ser social"

\footnotetext{
${ }^{118}$ Com efeito, “o que deve ser destacado no procedimento de Marx, para não se cair no viés gnosioepistêmico habitual, é, não o momento lógico da inversão entre sujeito e predicado, mas sim o estatuto ontológico que a orienta" (ENDERLE, 2000, p. 23).

${ }^{119}$ Diversos outros pesquisadores, além do próprio José Paulo Netto, supracitado, indicam a centralidade dessa compreensão: "Em 1843, na Crítica da filosofia do direito de Hegel, Marx considerava a obra em questão como a mais fiel expressão teórica do Estado moderno. Por essa razão, acreditava que as objeções que levantava contra o livro podiam ser estendidas à própria realidade correspondente" (SAMPAIO; FREDERICO, 2009, p. 27).
} 
(CHASIN , 2009, p. 64). Temos, aqui, a noção de crítica ontológica delineada acima: compreensão da gênese e necessidade social do complexo de que se trata, além da apreensão de sua lógica, passo inicial do entendimento.

No caso da crítica da política, assim, esse caráter ontológico resulta na proposição de uma inversão fundamental (em relação a Hegel e toda a tradição na qual se inseria), referendada anos depois, no escrito autobiográfico comentado no início deste capítulo, o "Prefácio" a Para a crítica da economia política:

\begin{abstract}
Minha investigação desembocou no seguinte resultado: relações jurídicas, tais como formas de Estado, não podem ser compreendidas nem a partir de si mesmas, nem a partir do assim chamado desenvolvimento geral do espírito humano, mas, pelo contrário, elas se enraízam nas relações materiais de vida, cuja totalidade foi resumida por Hegel sob o nome de 'sociedade civil' (bürguerliche Gesellschaft), seguindo os ingleses e franceses do século XVIII (MARX, 1982, p. 25).
\end{abstract}

Ainda que se aceite a ressalva de Celso Frederico e Benedicto Sampaio de que, nesse trecho, "Marx está se referindo às suas investigações no longo curso dos anos que se seguiram aos estudos iniciais da Filosofia do direito de Hegel, e não ao próprio texto de 1843" (SAMPAIO; FREDERICO, 2009, p. 17), o importante é reconhecer que o resultado de sua investigação corresponde a uma posição teórica original que, em essência, rompe progressivamente com o entendimento acerca da política e do Estado predominante até então (e, mesmo, deve-se reconhecer, até os dias atuais). De fato, o Manuscrito de Kreuznach contém um conjunto de contradições e insuficiências (ao se considerar a posterior evolução de Marx), sendo objeto de inúmeras controvérsias. Dada sua inegável complexidade (para além da complexidade da própria obra hegeliana contra a qual se insurge) será aqui abordada em seus aspectos mais gerais, aqueles que permitem visualizar o andamento da reflexão marxiana. Nesse sentido,

\footnotetext{
aqui se toma o aspecto revolucionário da Crítica: a postura de crítica históricosistemática que começa a se configurar na reflexão de Kreuznach conduz o procedimento analítico para além das fronteiras jurídico-políticas - a crítica política (recorde-se que esta é a motivação imediata de Marx) da filosofia do Estado, da história e sua recuperação sistemática pela filosofia passa a converter-se em crítica social, em crítica da sociedade (NETTO, 1983, p. 190).
}

Assim, retendo o caráter ontológico de buscar a lógica das próprias coisas (busca que não se encerra neste texto), Marx verifica a validade do primado da inversão entre sujeito e predicado na lógica hegeliana, proposto por Feuerbach, asseverando, como vimos: "família e sociedade civil são os pressupostos do Estado; elas são os elementos propriamente ativos; mas, na especulação, isso se inverte” (MARX , 2005, p. 30). Em 
suma, "o fato é que o Estado se produz a partir da multidão, tal como ela existe na forma dos membros da família e dos membros da sociedade civil” (MARX, 2005, p. 31). Nessa passada fundamental, o Estado deixa de ser considerado como o elemento propriamente ativo, isto é, o demiurgo da sociedade e de suas instituições, tal como se põe na filosofia hegeliana. Ao contrário, é a sociedade burguesa (em alemão, sinônimo de sociedade civil - bürgerliche Gesellschaft) que deve ser analisada como a fonte e a raiz do Estado momento a partir do qual o itinerário crítico marxiano se alarga e abrange a economia política clássica, principalmente a economia política inglesa, "o reflexo científico das condições em que se encontra a economia inglesa" (MARX, 2010a, p. 31). Em outros, e conhecidos, termos: "a anatomia da sociedade burguesa (bürgerliche Gesellschaft) deve ser procurada na Economia Política" (MARX, 1982, p. 25).

Nesse momento específico, porém, o Manuscrito de Kreuznach, o que temos é ainda a vinculação íntima com Feuerbach (ainda que, como vimos, tal vinculação termine por voltar-se contra este mesmo autor), isto é,

\begin{abstract}
sem muito esforço, percebe-se aqui o eco da teoria feuerbachiana da alienação, transposta da esfera onírica da religião para o campo turbulento da vida social. /.../. O Estado moderno, produto dos seres particulares (família e sociedade civil), surge na teoria hegeliana como o criador astucioso que dá vida aos seres particulares e deles se vale para realizar a sua universalidade. Marx, apoiandose em Feuerbach, interpreta o Estado hegeliano como a essência alienada da sociedade civil (FREDERICO, 1995, p. 61).
\end{abstract}

Nesse sentido, Marx aceita a descrição essencial acerca do Estado moderno presente na obra de Hegel, do trajeto que parte "do mundo greco-romano como marcado pela indiferenciação entre o social e o político" (FREDERICO , 1995, p. 61), mantida durante toda a Idade Média, na qual "a propriedade, o comércio, a sociedade o homem são políticos; /.../; cada esfera privada tem um caráter político ou é uma esfera política; ou a política é, também, o caráter das esferas privadas", isto é, na qual a "vida do povo e a vida política são idêntica" (MARX, 2005, p. 52), numa palavra: a vida é imediatamente pública. Tal integração, ainda, para Marx, deve-se à limitação dessas formas sociais, ou melhor, a uma limitação da esfera privada, pois "Onde o comércio e a propriedade fundiária ainda não são livres nem independentes, também não o é a constituição política", isto é, na Idade Média "o homem é o princípio real do Estado, mas o homem não livre" (MARX , 2005, p. 52). Enquanto na modernidade emerge uma contraposição efetiva entre essas esferas: "somente após a Revolução Francesa se consagra a separação entre as esferas. A atividade econômica emancipa-se então da regulamentação estatal e torna-se autônoma" (FREDERICO, 1995, p. 62), desvelando a sociedade civil como o 
reino do privatismo, dos fins privados e particulares, contraposta à universalidade do Estado, âmbito dos fins públicos e comunitários. Esta compreensão mais geral do processo civilizatório $^{120}$, depreendida de Hegel, é, então, mantida e o filósofo idealista é "criticado por tentar disfarçar o abismo que ele próprio descreveu ao tratar ao tratar das relações do Estado com a sociedade civil”" (FREDERICO , 1995, p. 62), através da teoria das mediações ${ }^{121}$.

Assim, o mundo moderno seria demarcado pela alienação da esfera política enquanto campo da gestão comunitária e compartilhada da vida social, dos fins humanos e universais, registrados no que Marx chama de constituição política - em relação à sociedade civil, domínio dos fins privados, individuais. Em suma: "entende-se que a constituição como tal só é desenvolvida onde as esferas privadas atingiram uma existência independente" e, nesse sentido, "a abstração do Estado como tal pertence somente aos tempos modernos porque a abstração da vida privada pertence somente aos tempos modernos. A abstração do Estado político é um produto moderno" (MARX, 2005, p. 52). Mais uma vez deve-se, nesse momento, apontar para os limites ${ }^{122}$ deste texto, ainda carente de referenciais teórico-analíticos que facultem a efetiva compreensão desse processo. Os artigos supracitados delineiam, exatamente, a busca desse referencial, bem como toda a trajetória posterior de Marx. De todo modo, é importante reter que, apesar de alteração de algumas categorias centrais, como mesmo a noção de política ${ }^{123}$, a descrição mais geral do processo civilizatório e de categorias centrais é mantida (ainda que, por suposto, grandemente enriquecida e complexificada ${ }^{124}$ ) como comprova o esclarecimento acerca do termo sociedade civil, realizada por Marx e Engels em nota de rodapé d'A ideologia alemã, após completar a crítica em relação a Hegel e Feuerbach:

A palavra sociedade civil [bürgerliche Gesellschafft] surgiu no século XVIII, quando as relações de propriedade já haviam se libertado da comunidade antiga e medieval. A sociedade civil, como tal, desenvolve-se somente com a

\footnotetext{
${ }^{120}$ Que continua tendo o grande mérito de entender o "desgarramento da sociedade civil /.../ como fruto de um processo histórico" (FREDERICO, 1995, p. 61).

${ }^{121}$ Dessas discussões resultam as poucas páginas que Marx dedica ao problema da burocracia, na medida em que esta era abordada por Hegel como uma das mediações fundamentais que rompia com o individualismo predominante na sociedade civil rumo ao universalismo estatal.

122 "Tal limitação diz respeito, precisamente, ao grau de radicalidade atingido na investigação da gênese e necessidade das categorias do real, grau este cuja insuficiência Marx não tardará em demonstrar e superar. /.... A crítica estaciona, assim, precisamente diante daquilo que deveria constituir sua tarefa principal: a investigação da lógica específica do homem real, ou seja, a análise da gênese e da necessidade da sociedade civil que engendra o Estado político" (ENDERLE, 2000, p. 53)

${ }^{123}$ Rubens ENDERLE (2000) bem aborda os limites da Crítica de 43, enquanto crítica do Estado, e não da política, ao longo do capítulo 2 de sua dissertação.

${ }^{124}$ Mais ainda ao longo dos Grundrisse, momento no qual Marx explicita o pleno domínio do referencial teórico da economia política.
} 
burguesia; com este mesmo nome, no entanto, foi continuamente designada a organização social que se desenvolve diretamente a partir da produção e do intercâmbio e que constitui em todos os tempos a base do Estado e da restante superestrutura idealista (MARX; ENGELS, 2007, p. 74).

Trata-se de uma questão fundamental à nossa pesquisa, dado o fato de referir-se, ainda que indiretamente, ao problema da individuação, isto é, da constituição e relação dos indivíduos com seus nexos sociais, bem como sobre a forma com a qual estes vínculos se configuram. E é fundamental reter que tem-se no próprio Hegel o entendimento da sociedade moderna como aquela na qual os indivíduos deparam-se com seus nexos sociais como elementos exteriores a eles e, portanto, meios aos seus fins privados, a partir da libertação da comunidade antiga e medieval, isto é, de formas sociais vistas como limitadas (exatamente por limitarem a própria ação dos indivíduos). Enfim, ainda que inserido no misticismo lógico, "as atividades humanas propriamente individuais da sociedade civil são, para Hegel, posteriores às atividades comuns do grupo natural (família), e, portanto, a consciência individual propriamente dita sucede lógica e historicamente à consciência grupal irrefletida. (As críticas de Marx às 'robinsonadas' dos economistas do século XVIII partem dessa linha de raciocínio)" (SAMPAIO; FREDERICO, 2009, p. 31). Desde já, portanto, o próprio surgimento de indivíduos, libertos de relações e restrições comunitárias (o que não quer dizer das relações sociais em geral), é entendido como o resultado de um largo processo histórico, e não como o princípio dado da história, ainda que, vale grifar mais uma vez, Marx não detenha instrumentos teóricos para desvendar esta lógica.

Reconhecendo, com a quase totalidade dos especialistas e estudiosos de Marx, que o mesmo não encontra resoluções (ou explicações) efetivas para tais questões no momento ${ }^{125}$, cabe verificar os artigos subsequentes que, por sua vez, explicitam exatamente o trajeto no qual Marx, desdobrando o giro anunciado, apercebe-se da necessidade de aprofundar os estudos em direção à economia política e efetiva seus primeiros contatos com essa matéria, momento no qual consolida progressivamente a formulação de um pensamento decisivamente original. Com efeito, se na Crítica da filosofia do direito de Hegel, produzida em Kreuznach em 1843, Marx identifica o teor

\footnotetext{
${ }^{125}$ Dentre os diversos limites verificados nesse texto, destaca-se o fato de que vários de seus elementos centrais, que constituirão eixos estruturais do pensamento de Marx comparecem ainda como princípios, carentes de explicitação e compreensão, de modo que as prospectivas imbuem-se de caráter abstrato e, ainda, democrático. Mesmo no caso da política, tem-se aí uma posição que será logo superada, isto é, a propositura de uma "democracia verdadeira", numa palavra: da "supressão política da propriedade privada ou, melhor dizendo, a constituição de um regime no qual a propriedade se veja privada de todo caráter político" (ENDERLE, 2000, p. 54).
} 
da crítica verdadeiramente filosófica, não chega aí a uma nova concepção de ser social, como referenda, de maneira precisa, Mariano F. Enguita (1993, p. 66) ao reconhecer que mesmo ao final de 1843, isto é, com o "Crítica da filosofia do direito de Hegel Introdução", Marx "continua no ponto alcançado por Feuerbach frente ao idealismo enquanto concebe o sensível ainda como objeto e não como atividade, mas já o ultrapassou na medida em que seu objeto já não é um objeto natural-abstrato mas histórico-social, já não o homem e sim o proletariado". É esta ultrapassagem primeira de Feuerbach (nesta citação, tomar o objeto como histórico-social), então, que será completada e complementada com a crítica da economia política (e o desvendamento do objeto como atividade), o centro de nossa análise a partir dos três artigos publicados por Marx até julho de 1844.

Com efeito, no artigo "Sobre a questão judaica", escrito entre setembro e outubro de 1843 , não temos ainda o ponto alcançado em dezembro ${ }^{126}$, mas um desdobramento radical da inversão (entre Estado e sociedade civil) em certa medida apenas proposta na Crítica de Kreuznach ${ }^{127}$, enfocando-a a partir de um problema político concreto - a relação dos judeus com o Estado - e a busca explícita de novos referenciais teóricos para a explicação das contradições observadas. No caso do primeiro item constitui, por sua vez, um avanço na comparação com o texto anterior, ainda que "o leitmotiv a conduzir o texto continua entretanto o mesmo: após a Revolução Francesa cristalizou-se a irreconciliável oposição entre Estado e sociedade civil” (FREDERICO , 1995, P. 96), agora problematizada por Marx a partir da original distinção entre "emancipação política" e "emancipação humana", o que exatamente possibilita a superação de seus limites, materializados na proposta, explícita da Crítica de 43 da superação política da propriedade privada. Desdobremos esse primeiro aspecto do artigo em tela.

Concretamente, no âmbito da relação dos judeus com o Estado e com a emancipação política temos "la ubicación del problema en el ámbito de la sociedad y no en el Estado" (SARTELLI, 2012, p. 25), isto é, a confirmação do giro anunciado na Crítica de 43: a sociedade civil como esfera determinante do estado ${ }^{128}$. De modo que, em

\footnotetext{
${ }^{126}$ A identificação do proletariado na "Crítica da Filosofia do Direito de Hegel - Introdução", identificada acima por Enguita.

127 "Aquilo que na Crítica da filosofia do Estado de Hegel aparece apenas como alguns passos ainda vacilantes, em $A$ questão judaica converte-se já numa marcha decidida. Aqui aparecem pela primeira e última vez, com o máximo de claridade, o paralelismo e a relação intrínseca entre a crítica da religião, a crítica da política e a crítica da economia na obra de Marx" (ENDERLE, 2000, p. 55).

${ }^{128}$ Giro com o qual "ele ultrapassa seu amigo Ruge, um hegeliano de esquerda partidário das soluções
} 
relação a esse artigo, vale perceber que sua questão fundamental, em realidade, não é a questão judaica em si, mas sim "la naturaleza de la emancipación humana, el espacio en el que se da la batalla y el lugar que ocupan en ella las contradicciones secundarias" (SARTELLI , 2012, p. 7), e que, nesse sentido, ao não oferecer nenhuma solução à questão judaica real, Marx “simplemente señala que se resoverá solo cuando cambien las condiciones sociales que le dan vida. Yace aquí su superiodad con respecto a Bauer, la ubicación de la religión en el conjunto de las relaciones sociales $\mathrm{y}$, por ende, su descentralización con respecto al conjunto de la vida política" (SARTELLI, 2012, p. 12). Ou seja, no debate sobre a questão judaica, Marx (2010, p. 38) remete a discussão para "o estado e seus pressupostos gerais", indicando que não chegar a este mote constitui, em realidade, um dos limites de seu contendor, o filósofo Bruno Bauer, seu antigo companheiro do movimento neohegeliano:

\begin{abstract}
Essa desavença secular, à qual acaba se reduzindo toda a questão judaica, ou seja, a relação entre o Estado político e seus pressupostos, quer se trate de elementos materiais, como a propriedade privada etc., ou espirituais, como a formação e a religião, a desavença entre o interesse geral e o interesse particular, a divisão entre o Estado político e a sociedade burguesa, todos esses antagonismos seculares são mantidos por Bauer enquanto ele polemiza contra sua expressão religiosa (MARX, 2010, p. 41) ${ }^{129}$.
\end{abstract}

Veremos logo adiante a "resolução" marxiana da questão (que envolve a já citada problematização original e radical da distinção entre emancipação política e humana). $\mathrm{O}$ intuito, nesse momento, é assinalar o aprofundamento da inversão notada nas Glosas de Kreuznach: a sociedade civil (em seus elementos materiais ou espirituais) como o elemento determinante, o pressuposto, do Estado e sua organização. Ademais, Marx (2010, p. 40) igualmente acentua, neste texto, que é a sociedade civil em suas contradições que erige o Estado, isto é, que seus efetivos pressupostos correspondem às diferenças sociais realmente existentes, quais sejam, "a diferenciação por nascimento, estamento, formação e atividade laboral".

Mesmo quando o Estado efetua a anulação política da situação concreta - "ao proclamar cada membro do povo, sem consideração dessas diferenças, como participante

puramente 'políticas' (a República), e vira-se não mais para o Estado como 'verdade' dos problemas sociais (como o sofrimento do pobre), como ainda era sua posição nos artigos da Gazeta Renana, mas para o povo real, para a vida social" (LÖWY, 2011, p. 23). Em outras palavras, a partir deste artigo, "a questão não reside mais, por conseguinte, em buscar uma solução política para além da esfera do Estado abstrato mas, antes, uma solução social para além da esfera abstrata da política, cuja forma acabada é justamente a democracia" (ENDERLE, 2000, p. 55).

${ }^{129}$ Acerca dessa passagem, Celso FREDERICO (cf. 1995, p. 100) acentua a ambiguidade presente no texto marxiano acerca dos "pressupostos" do Estado. 
igualitário da soberania nacional” (MARX, 2010, p. 40) - em realidade implica na sua existência e o seu domínio na vida social, em outros termos: "a anulação política da propriedade privada não só não leva à anulação da propriedade privada, mas até mesmo a pressupõe" (MARX, 2010, p. 39). O raciocínio, ao fim e ao cabo, é cristalino, constituindo a crítica básica de Marx à democracia formal: afinal, se o domínio da propriedade privada não existisse concretamente, não necessitaria ser politicamente anulado, ou então, se, na sua vida concreta, os homens fossem realmente livres, esta liberdade não necessitaria ser afirmada pela lei, os homens simplesmente seriam livres. Desse modo, em relação ao Estado politicamente emancipado, reconhece Marx (2010, p. 40) que "longe de anular essas diferenças fáticas, ele existe tão somente sob o pressuposto delas, ele só se percebe como Estado político e a sua universalidade só se torna efetiva em oposição a esses elementos próprios dele”, bem como supera exatamente sua proposta na Crítica de 43 - como vimos, a anulação política da propriedade privada (sua desconsideração por parte da constituição ${ }^{130}$ ).

Tais concepções - a consideração da sociedade civil como elemento determinante e a origem do estado nas contradições da vida social - não apenas reaparecem como são enriquecidas nos artigos posteriores, em especial ao identificar de maneira cada vez mais precisa que são os limites da sociedade civil que engendram o Estado. Mas um ponto a ser destacado nesse texto é a identificação dos novos referenciais teóricos que facultam a Marx avançar na crítica à sociedade burguesa e sua forma de individuação, isto é, se "no plano teórico mais geral, 'A questão judaica' reafirma a orientação presente nos Manuscritos de Kreuznach /.../ ao sair da crítica filosófica e passar para um tema político concreto, Marx foi forçado a ampliar o seu referencial teórico" (FREDERICO, 1995, p. 96). Neste momento, a influência mais determinante (em especial na segunda parte do artigo) é um artigo de Moses Hess, publicado nos mesmos Anais franco-alemães, "Sobre a essência do dinheiro". Assim, além de aprofundar sua compreensão de Estado e de política, Marx aprofunda também, num processo progressivo, sua crítica da sociedade burguesa, na medida em que, em realidade, a "emancipação política" constitui a emancipação da sociedade burguesa em relação à política. Vejamos esta questão fundamental.

\footnotetext{
130 "A estratificação censitária é a última forma política de reconhecimento da propriedade privada"
} (MARX, 2010, p. 39). 
Como vimos, Marx inicia por rebaixar o estatuto da emancipação política, ou cidadã, por não corresponder à emancipação real e universal dos homens e, ao contrário, pressupor os elementos de diferenciação dos homens entre si; isto é, "o limite da emancipação política fica evidente de imediato no fato de o Estado ser capaz de se libertar de uma limitação sem que o homem realmente fique livre dela, no fato de o Estado ser um Estado livre [Freistaat, república], sem que o homem seja um homem livre" (MARX, 2010, p. 38-9). Por tratar-se da "questão judaica", o ponto inicial da polêmica é a religião: “O Estado pode, portanto, já ter se emancipado da religião, mesmo que a maioria esmagadora continue religiosa" (MARX, 2010, p. 39) ${ }^{131}$, de modo que "a elevação política do homem acima da religião compartilha de todos os defeitos e de todas as vantagens de qualquer elevação política” (MARX, 2010, p. 39).

Páginas à frente, Marx delineia claramente tanto os defeitos como as vantagens de qualquer elevação política, reconhecendo como um inegável avanço, um grande progresso a conquista de direitos civis pela população e identificando seu limite essencial pelo fato de representar a manutenção da ordem social dada: "a emancipação política de fato representa um grande progresso; não chega a ser a forma definitiva da emancipação humana em geral, mas constitui a forma definitiva da emancipação humana dentro da ordem mundial vigente até aqui” (MARX, 2010, p. 41). Em suma, os avanços e limites da emancipação política consistem em manter intactos os pilares fundamentais da sociedade moderna, possibilitando, na realidade, a sua plena configuração: "a emancipação política representou concomitantemente a emancipação da sociedade burguesa em relação à política, até em relação à aparência de um teor universal" (MARX, 2010, p. 52).

É nesse passo, ao bem caracterizar os limites da emancipação política, que Marx esclarece e aprofunda o conteúdo de sua crítica da sociedade burguesa, que se emancipa da política: "o ato de sacudir de si o jugo político representou concomitantemente sacudir de si as amarras que prendiam o espírito egoísta da sociedade burguesa” (MARX, 2010, p. 52). Marx retorna, assim, ao ponto que comentávamos, linhas acima, a propósito das Glosas de Kreuznach: a contraposição entre Estado e sociedade civil configurada a partir da Revolução Francesa, a revolução política por excelência. Nesse sentido, as amarras

\footnotetext{
131 Como reafirma em outra passagem: "A emancipação do Estado em relação à religião não é a
} emancipação do homem real em relação à religião” (MARX, 2010, p. 46). 
que prendiam o espírito egoísta da sociedade burguesa correspondem ao Estado que resguardava, ao tempo do feudalismo ${ }^{132}$, ainda, algum caráter comunitário real, concreto - aspecto que Marx sempre ressalta enquanto uma limitação, nunca é demais lembrar. Em seus termos: "a sociedade burguesa antiga possuía um caráter político imediato, isto é, os elementos da vida burguesa, como, p. ex., a posse ou a família ou o modo de trabalho, forma elevados à condição de elementos da vida estatal nas formas da suserania, do estamento e da corporação" (MARX, 2010, p. 51). Numa palavra: as atividades dos indivíduos tinham, imediatamente, um conteúdo público, comunitário: "as funções vitais e as condições de vida da sociedade burguesa permaneciam sendo políticas" (MARX, 2010, p. 52). De modo que as suas condições sociais, sua pertença específica a algumas dessas "sociedades particulares dentro da sociedade", eram tomadas como sua condição própria e natural, isto é, "transformavam sua atividade e situação burguesa específica em sua atividade e situação universal" (MARX, 2010, p. 52).

Claramente veremos que Marx enriquece o entendimento desse processo nos textos posteriores. De todo modo, percebe-se aqui a determinação mais precisa da sociedade civil, ou sociedade burguesa e, portanto, da forma de individuação burguesa (dos indivíduos que se constituem nessas específicas relações sociais) - o que a confirma como uma das questões essenciais no momento de configuração de seu pensamento: "a revolução política superou o caráter político da sociedade burguesa. Ela decompôs a sociedade burguesa em seus componentes mais simples, ou seja, nos indivíduos, por um lado, e, por outro, nos elementos materiais e espirituais que compõem o teor vital, a situação burguesa desses indivíduos" (MARX, 2010, p. 52). Isto é, na medida em que a revolução política

desmantelou forçosamente o conjunto dos estamentos, corporações, guildas, privilégios, que eram outras tantas expressões da separação entre o povo e seu sistema comunitário. /.../. A atividade vital específica e a situação vital específica foram reduzidas a uma importância apenas individual. Elas não mais constituíam a relação universal do indivíduo com a totalidade do Estado (MARX, 2010, p. 52).

Ou seja, deixaram de ser determinadas politicamente, no que reside, aliás, o avanço da emancipação política. No entanto, como vimos, o outro lado desse avanço é o

\footnotetext{
${ }^{132}$ Que, nessa passagem, Marx designa de "sociedade burguesa antiga". Dada a complexidade semântica do termo, já comentada, talvez poderíamos igualmente entender por "sociedade civil antiga", lembrando o comentário de Marx e Engels (2007, p. 74) acerca desse vocábulo, já citado: "A sociedade civil, como tal, desenvolve-se somente com a burguesia; com este mesmo nome, no entanto, foi continuamente designada a organização social que se desenvolve diretamente a partir da produção e do intercâmbio e que constitui em todos os tempos a base do Estado e da restante superestrutura idealista”.
} 
desdobramento pleno do espírito egoísta: "só que a realização plena do idealismo do Estado representou concomitantemente a realização plena do materialismo da sociedade burguesa" (MARX, 2010, p. 52).

É a partir dessa compreensão, enfim, que Marx estabelece a crítica ao conjunto dos direitos do homem, expostos na Declaração dos direitos do homem e do cidadão, de 1791, um dos momentos do entusiasmo juvenil da vida política: "nenhum dos assim chamados direitos humanos transcende o homem egoísta, o homem como membro da sociedade burguesa, a saber, como indivíduo recolhido ao seu interesse privado e ao seu capricho privado e separado da comunidade" (MARX, 2010, p. 50). A centralidade da questão da individuação, ou melhor, de sua conformação na sociedade burguesa é, aqui, evidente: o indivíduo burguês é caracterizado como aquele que se encontra apartado do conjunto do gênero humano, fato expresso nos direitos humanos manifestos na declaração supracitada, dentre eles o da liberdade: "o direito humano à liberdade não se baseia na vinculação do homem com os demais homens, mas, ao contrário, na separação entre um homem e outro" (MARX, 2010, p. 49). Em outros termos, na medida em que o direito à liberdade é definido como o "poder que pertence ao homem de fazer tudo quanto não prejudica os direitos do próximo", destaca Marx que os homens são postos como limites uns aos outros, obstáculos à realização dos fins de cada um. É nesse sentido que "muito longe de conceberem o homem como um ente genérico, esses direitos deixam transparecer a vida do gênero, a sociedade, antes como moldura exterior ao indivíduo, como limitação de sua autonomia original", de modo que, nesses direitos, expressa-se uma sociabilidade em que "o único laço que os une é a necessidade natural, a carência e o interesse privado, a conservação de sua propriedade e de sua pessoa egoísta" (MARX, 2010, p. 50).

Cabe ressaltar, para bem compreender a posição marxiana, que os direitos humanos, tal como politicamente expostos e afirmados na declaração, não constituem uma pura "ideologia", uma pura "mistificação" da realidade, mas enraízam-se no modo de ser dos próprios indivíduos, configurado em determinado momento da história: "a aplicação prática do direito humano à liberdade equivale ao direito humano à propriedade privada" (MARX, 2010, p. 49). Ou seja, é a sociedade burguesa que se fundamenta numa relação que contrapõe os homens uns aos outros. É por isso que Marx define tanto o direito à liberdade, em que temos a "liberdade do homem como mônada isolada e recolhida dentro de si mesma", como o da propriedade, em suas palavras, "o direito de 
desfrutar a seu bel prazer, sem levar outros em consideração", como a "base da sociedade burguesa" (MARX, 2010, p. 49).

E, por fim, tal sociedade assim se configura pois seu "deus secular" é o dinheiro: "a necessidade prática, o egoísmo, é o princípio da sociedade burguesa e se manifestará em sua forma pura no momento em que a sociedade burguesa e se manifestará em sua forma pura no momento em que a sociedade burguesa tiver terminado de gerar o Estado político. O deus da necessidade prática e do interesse próprio é o dinheiro" (MARX, 2010, p. 58). Nas passagens conclusivas desse artigo de Marx nota-se sua relação com o movimento mais geral de dissolução do hegelianismo. Celso FREDERICO (1995, p. 100) destaca que

ao passar da crítica à religião à crítica à política, Marx conclui seu ensaio fazendo considerações sobre o culto judaico ao dinheiro, considerações essas que refletem diretamente a recente influência do texto de Moses Hess - autor que também havia recorrido à teoria feuerbachiana para dar conta de temas do mundo profano, e viu no dinheiro a essência alienada do homem $^{133}$.

Com efeito, a noção do dinheiro como essência alienada do homem é explícita neste texto marxiano: "o dinheiro é a essência do trabalho e da existência humanos, alienada do homem; essa essência estranha a ele o domina e ele a cultua" (MARX, 2010, p. 58). Anunciam-se, nessa passagem, determinações fundamentais que serão melhor desdobradas em seus estudos de 1844: o trabalho como essência humana e a questão do estranhamento. Reconheçamos, ainda, que a alienação política, objeto da consideração marxiana, é, já aqui, remetida à alienação explicitada no dinheiro, na medida em que esta refere-se às condições reais de vida, à existência humana ${ }^{134}$. No entanto, a influência de Hess permite também divisar que embora já aborde um tema do âmbito da economia, Marx ainda o faz em um plano estritamente filosófico, ou melhor, ainda sem elevar as categorias da economia ao plano filosófico, como destaca, dentre outros, Daniel Bensaïd (2010, p. 93):

Na falta de já dispor, em Sobre a questão judaica, de uma conceitualização crítica da economia política, sua crítica assemelha-se à crítica moral tradicional, dos dinheiros de Judas aos prodígios da Bolsa em Zola, das maldições contra "o dinheiro sujo" às diatribes de Péguy contra "o espírito dos estabelecimentos de fundos de poupança", da denúncia do espírito de

${ }^{133}$ Ainda em 1844, nos Manuscritos econômico-filosóficos, posteriormente objeto de nossa análise, "tudo indica que as concepções de Marx sobre o dinheiro, então, recolhiam sugestões de Moses Hess" (NETTO, 1981, p. 58).

${ }^{134}$ Com efeito, acerca de outra passagem do mesmo texto, Adam Schaff (1967, p. 133) assevera: "continua expressando-se em linguagem estranha, mas começamos a atingir o centro das ideias de Marx, que o leva, logicamente, a conclusões comunistas, embora dirigindo o seu interesse, ao mesmo tempo, para a economia: a base de toda alienação, na sociedade capitalista, é a alienação econômica. Ela está na base na alienação sociopolítica, ela condiciona a alienação ideológica". 
acumulação, feita por Valéry, ao papel simbólico da matéria fecal freudiana. Com a diferença - decisiva - que Marx já estava engajado numa via que o levará à crítica da economia política e a descobrir o segredo do valor. No entanto, em 1844, ele ainda não concebe o dinheiro como equivalente geral da troca mercantil generalizada, como forma suprema do fetichismo da mercadoria, mas somente como fetiche monetário.

De todo modo, para além da identificação de mais esses limites (a partir da comparação com a obra marxiana posterior), é fundamental reter que Marx aponta para uma "virada materialista" - a explicação do "judeu secular real" a partir de suas condições reais de vida: "não procuremos o mistério do judeu em sua religião; procuremos, antes, o mistério da religião no judeu real" (MARX, 2010, p. 56); e, simultaneamente, para as condições de "resolução" da questão judaica - que se encontra na própria emancipação dos homens em relação às condições que geram o judaísmo: “a emancipação em relação ao negócio e ao dinheiro, portanto, em relação ao judaísmo prático, real, seria a autoemancipação da nossa época” (MARX, 2010, p. 56).

Pontos centrais que nos permitem, a fim de concluir as considerações acerca desse texto, problematizar a noção nuclear de emancipação humana que, como já vimos, encontra-se num patamar superior em relação à emancipação política (a liberdade possível dentro de ordem atual). Enfim, enquanto esta última "é a redução do homem, por um lado, a membro da sociedade burguesa, a indivíduo egoísta independente, e, por outro, a cidadão, a pessoa moral", isto é, demarca a cisão presente na vida concreta dos homens - uns em relação aos outros e à sua vida comunitária; a emancipação real, verdadeiramente humana

só estará plenamente realizada quando o homem individual real tiver
recuperado para si o cidadão abstrato e se tornado ente genérico na qualidade
de homem individual na sua vida empírica, no seu trabalho individual, nas suas
relações individuais, quando o homem tiver reconhecido e organizado suas
"forces propres" como forças sociais e, em consequência, não mais separar de
si mesmo a força social na forma da força política (MARX, 2010, p. 54).

Ou seja, a alienação política é vista como o apartamento das forças sociais dos próprios indivíduos e sua cristalização em instituições alheias ao seu controle, nesse caso, das forças relativas à gestão da vida coletiva ${ }^{135}$. Razão pela qual reaver o cidadão abstrato, para o homem individual real implica na sua conversão em ente genérico na sua vida concreta, na superação dos conflitos cotidianos reais. O caminho para tal subversão, no entanto, não são indicados no presente texto. Fato que demarca a acelerada evolução do pensamento de Marx, na medida em que aparecem (ainda que como princípios) no

135 O Estado "é uma organização que administra os complicados assuntos da vida social" (SCHAFF, 1967, p. 130). 
texto escrito alguns meses depois, e publicado nos mesmos Anais franco-alemães: a "Introdução" ao seu estudo Crítica da filosofia do direito de Hegel. Voltemos a ele nossa atenção.

Artigo escrito em dezembro de 1843, inicia por reafirmar o caráter ontológico de sua crítica, isto é, o fato de que "a crítica da filosofia alemã do direito e do Estado, que teve a mais lógica, profunda e completa expressão em Hegel, surge ao mesmo tempo como a análise crítica do Estado moderno e da realidade a ele associada". A filosofia hegeliana representa a apreensão, no pensamento, das características essenciais do Estado, na medida em que "em política, os alemães pensaram o que as outras nações fizeram. A Alemanha foi a sua consciência teórica", de modo que a crítica dessa filosofia é também a análise crítica do Estado moderno e da realidade a ele associada, para, na sequência dessa passagem, assentar a negatividade do Estado moderno, ou seja, o fato de que "o status quo da ciência política alemã exprime a imperfeição do Estado moderno em si, a degenerescência da sua carne" (MARX, 2005, p. 151). Demarque-se, mais uma vez, a distância em relação às Glosas de Kreuznach, como vimos, estruturada a partir da reivindicação da anulação política da propriedade privada. Aqui, por sua vez, a própria política é refutada, como imperfeita em si, convertendo a "crítica da teologia em crítica da política": "a tarefa imediata da filosofia, que está a serviço da história, é desmascarar a auto-alienação humana nas suas formas não sagradas" (MARX, 2005, p. 146). Ao tempo que se reafirma de maneira vigorosa o humanismo marxiano: "a crítica da religião termina com a doutrina de que o homem é o ser supremo para o homem" (MARX, 2005, p. 151). Com efeito, "é evidente que a luta sustentada contra a alienação representava a luta pelo humanismo consequente, só possível no antropocentrismo" (SCHAFF, 1967, p. $124)^{136}$.

Reafirma-se também, ao lado do reconhecimento da negatividade da política, a determinação da "revolução parcial, meramente política" como inferior à "revolução radical, a emancipação humana universal", na medida em que "deixa de pé os pilares do edifício". Marx retoma, assim, a distinção estabelecida em "Sobre a questão judaica", reconhecendo neste momento que a revolução política constitui aquela que mantém a

${ }^{136}$ O ensaísta polonês desdobra esta questão a partir das palavras do “jovem” Engels (apud SCHAFF, 1967, p. 124): "a pergunta, até agora, sempre foi: o que é Deus? E a filosofia alemã resolve a pergunta: Deus é o homem. O homem precisa somente tomar consciência de si, medir todas as condições de vida em si, julgálas segundo sua essência, organizar o mundo segundo as exigências de sua natureza realmente humana e, então, resolverá o enigma dos nossos tempos". 
estrutura de classes e, portanto, de domínio e opressão dos homens entre si. Isto é, "qual a base de uma revolução parcial, meramente política? Apenas esta: uma seção da sociedade civil emancipa-se e alcança o domínio universal” (MARX, 2005, p. 154).

É no desdobramento desse raciocínio, e a especificação da emancipação humana universal, que encontra-se o avanço essencial deste texto - mesmo que ainda apareça na forma de um princípio e contenha, este mesmo avanço, certos limites -, qual seja, a referida identificação do agente social associado à emancipação humana: o proletariado, enquanto "a classe que realiza a liberdade social" (MARX, 2005, p. 155). Com efeito, é sumamente conhecida a passagem em que Marx identifica a perda total da humanidade - presente na "esfera que possua caráter universal porque os seus sofrimentos são universais e que não exige uma reparação particular porque o mal que lhe é feito não é um mal particular, mas o mal em geral" (MARX, 2005, p. 155) - como condição de realização de uma revolução que não pretende estabelecer o domínio de uma classe particular sobre a sociedade, mas a libertação de todas as classes, isto é, da classe que, por seu sofrimento universal e por sua perda total, "só pode redimir-se a si mesma por uma redenção total do homem” (MARX, 2005, p. 156).

Os supracitados limites referem-se ao fato de que, ainda que ressaltado por Marx o caráter prático necessário à resolução dos problemas sociais, bem como o papel do proletariado, isto é, que "a crítica da Introdução já não é uma crítica teórica mais ou menos atenta às questões práticas: é uma crítica teórica que quer dirigir uma luta prática. /.... A crítica é agora apenas um meio, mas, em geral, o pensamento continua representando a parte ativa e o movimento real, a parte passiva do processo" (ENGUITA, 1993, p. 62). Isto é, embora Marx afirme que "a crítica da filosofia especulativa do direito não se oriente em si mesma, mas em tarefas que só podem ser resolvidas por um único meio: a atividade prática" (MARX, 2005, p. 151), ainda é restrita a determinação da categoria de prática, cuja especificação efetiva apenas completar-se-á, como veremos, com a crítica da economia política. Ainda que Marx, assim, apresente, como princípio, a noção de atividade prática e, mesmo, do proletariado como agente associado à revolução social, o caráter ativo recai à filosofia: "Assim como na época [da reforma protestante, DAS] a revolução começou no cérebro de um monge, hoje é no cérebro do filósofo que ela começa"; cabendo ao proletariado a noção de agente passivo: "as revoluções precisam de um elemento passivo, de uma base material” (MARX, 2005, p. 152) e, mais esclarecedora, "a filosofia é a cabeça desta emancipação e o proletariado é o seu coração" 
(MARX, 2005, p. 156). Vejamos o desdobramento de Enguita (1993, p. 63), acerca dessa questão, a partir da passagem sobre o proletariado acima citada:

O proletariado assim analiticamente descrito (uma descrição que é a reprodução ampliada da já contida na Crítica da filosofia do estado de Hegel da "classe do trabalho imediato"), apresenta-se, pois, como a crítica viva da ordem social existente; mas a crítica, que nos permitam a expressão, é entendida como espetáculo. O que Marx tem em vista não é a atividade, mas a situação do proletariado. A localização da classe revolucionária, portanto, não altera seu papel passivo nem, por conseguinte, o papel ativo exclusivo da crítica, da filosofia.

Mais uma vez confirmando o acelerado desenvolvimento das ideias marxianas, Enguita constata ainda que a redação dos Manuscritos econômico-filosóficos, entre abril e agosto de 1844, explicitam, dentre outros elementos, a superação dessa antinomia, ou dualidade filosofia-proletariado presente na Introdução. Nesse sentido, coaduna com as posições de José Chasin, Celso Frederico e José Paulo Netto, dentre outros, que identificam um salto qualitativo, nos referidos manuscritos, na definição de uma concepção de mundo substancialmente original. Por via de consequência, envolve a crítica da economia da política e o contato de Marx com os círculos operários socialistas. Abordaremos este ponto no próximo tópico, oportunidade de evidenciar a noção de atividade sensível que aí se constitui e é desdobrada por toda A ideologia alemã. Antes de alcançarmos este tema central, cabe, no entanto, aludir a um artigo escrito em julho de 1844, cuja mote essencial ainda é a crítica da política e do entendimento político.

Referimo-nos ao texto intitulado "Glosas críticas ao artigo 'O rei da Prússia e a reforma social'. De um prussiano" ${ }^{137}$, que configura verdadeiramente uma ruptura em relação à tradição da filosofia política ocidental ${ }^{138}$. Um dado imediato que expressa a ruptura antitética de Marx em relação ao seu pensamento anterior, inserido na tradição ocidental, ontopositiva, como veremos, é o fato de que exatamente com Ruge que Marx havia coeditado o único número dos Anais franco-alemães, no qual publicara os dois artigos comentados anteriormente, isto é, “As Glosas Críticas constituem, por esse aspecto, um documento de ruptura pública de Marx com um dos últimos neohegelianos

\footnotetext{
137 “Trata-se de um comentário polêmico de Marx a um artigo publicado em julho de 1844 pelo jovemhegeliano - de sensibilidade democrática/republicana - Ruge, sob o pseudônimo 'Um prussiano', no Vorwärts, um jornal editado por exilados alemães em Paris. As 'glosas' de Marx foram publicadas no mesmo periódico, em agosto de 1844" (LÖWY, 2011, p. 29). Destaque-se, ainda, que "o tema do debate entre Marx e Ruge é o levante dos tecelões na Silésia, em junho de 1844, a primeira revolta operária da história alemã moderna, esmagada pelo Exército prussiano" (LÖWY, 2011, p. 31).

138 "O marxismo se revela como a mais alta contribuição para a compreensão do Estado e da política nas sociedades contemporâneas. Na obra de Marx já se expõe a mudança radical no modo de entender as categorias políticas e os fenômenos sociais como o Estado" (MASCARO, 2013, p. 11).
} 
com quem ainda mantinha, até então, certas relações pessoais e intelectuais" (CHASIN, 2000, p. 153).

Neste texto, Marx retoma a noção da imperfeição do Estado moderno, identificando sua impotência na resolução dos problemas e contradições sociais, do pauperismo em especial, e, de outro lado, o fato de que "todos os Estado buscam a causa nas falhas casuais ou intencionais da administração e, por isso mesmo, em medidas administrativas o remédio para suas mazelas" (MARX, 2010a., p. 39), para, então, desdobrar de maneira vigorosa que ambos se devem ao fato de que o próprio Estado se fundamenta nesses limites da vida social. Vale a citação completa:

\begin{abstract}
O Estado não pode suprimir a contradição entre a finalidade e a boa vontade da administração, por um lado, e seus meios e sua capacidade, por outro, sem suprimir a si próprio, pois ele está baseado nessa contradição. Ele está baseado na contradição entre a vida pública e a vida privada, na contradição entre os interesses gerais e os interesses particulares. Em consequência, a administração deve restringir-se a uma atividade formal e negativa, porque o seu poder termina onde começa a vida burguesa e seu labor. Sim, frente às consequências decorrentes da natureza associal dessa vida burguesa, dessa propriedade privada, desse comércio, dessa indústria, dessa espoliação recíproca dos diversos círculos burgueses, frente a essas consequências a lei natural da administração é a impotência (MARX, 2010a., p. 39).
\end{abstract}

O núcleo central da concepção marxiana da política é cristalino: decorre dos limites da vida social sobre a qual se erige. Em suma: "a existência do Estado e a existência da escravidão são inseparáveis" (MARX, 2010a., p. 39). Na medida em que se fundamenta, ou se baseia, no escravismo da sociedade burguesa, de sua natureza associal, o Estado não pode contra ela se voltar, pois estar-se-ia voltando contra si mesmo e "o suicídio é antinatural" (MARX, 2010a., p. 40), isto é, "se quisesse eliminar a impotência de sua administração, o Estado moderno teria de eliminar a atual vida privada. Se ele quisesse eliminar a vida privada, teria de eliminar a si mesmo, porque ele existe tão somente como antítese a ela" (MARX, 2010a., p. 40).

Ademais, alicerçando-se na contraposição entre interesses gerais e interesses particulares, isto é, na propriedade privada, a própria origem dos "males sociais"139, o Estado torna-se mesmo incapaz de compreender esta origem. "O Estado não pode, portanto, acreditar que a impotência seja inerente à sua administração, ou seja, a si mesmo. Ele pode tão somente admitir deficiências formais e causais na mesma e tentar corrigi-las" (MARX, 2010a., p. 40). Marx efetua, aqui, também, a crítica do entendimento

\footnotetext{
${ }^{139}$ Acentua, ainda, Marx, na sua ironia conhecida: "E como são pervertidas essas pessoas particulares! Eles reclamam do governo toda vez que este limita sua liberdade, mas exigem do governo que este impeça as consequências necessárias desta liberdade" (MARX, 2010a., p. 40).
} 
político, isto é, o entendimento que se limita e circunscreve à política, que se acentua com o próprio fortalecimento da política:

\begin{abstract}
Quanto mais poderoso for o Estado, ou seja, quanto mais político for um país, tanto menos estará inclinado a buscar no princípios do Estado, ou seja, na atual organização da sociedade, da qual o Estado é expressão ativa, autoconsciente e oficial, a razão das mazelas sociais e a compreender seu princípio universal. O entendimento político é entendimento político justamente porque pensa dentro dos limites da política. Quanto mais aguçado, quanto mais ativo ele for, tanto menos capaz será de compreender mazelas sociais (MARX, 2010a., p. 40-1).
\end{abstract}

Assim, na concepção marxiana que se institui nesse momento, tanto a política quanto o entendimento político são apreendidos em sua negatividade. Para a primeira, enquanto expressão dos limites e mazelas sociais. Para o segundo, como forma de reflexão que se mantém na estreiteza dessas ordenações sociais. Esta negatividade permite, assim, compreender "a ideia central do artigo: a diferença entre luta política (aquela voltada contra um determinado poder do Estado) e luta social (a luta de classes entre o proletariado e a burguesia)" (FREDERICO, 1995, p. 112). A primeira é aquela que se mantém nos limites estreitos do entendimento político, que busca em transformações no estado a resolução de suas demandas associadas às condições de vida. Mantendo-o,

\footnotetext{
o proletariado - ao menos no início do movimento - desperdiça suas forças em rebeliões insensatas, inúteis e sufocadas em sangue. Por pensar na forma da política, ele vislumbra a causa de todas as mazelas na vontade e todos os meios para solucioná-las na violência e na derrubada de uma determinada forma de Estado. Prova: as primeiras rebeliões do proletariado francês. Os trabalhadores de Lyon acreditavam estar perseguindo apenas propósitos políticos, pensavam ser apenas soldados da república, quando, na verdade, eram soldados do socialismo (MARX, 2010a., p. 48-9).
}

Não nos parece excesso de zelo, a propósito deste artigo, reafirmar alguns pontos, dada sua originalidade inegável em relação ao ambiente teórico e intelectual contemporâneo. Como vimos, Marx, em certo sentido, reafirma alguns dos princípios já delineados nos artigos anteriores (ao mesmo tempo que os desdobra e aprofunda). Devese, no entanto, atentar ao fato de que, absolutamente contrário ao "padrão" atual, não se trata da “'aplicação' de um referencial teórico a um caso concreto, o que é totalmente estranho aos procedimentos analíticos marxianos, mas uma espécie de redescoberta das mesmas determinações a partir da análise de uma ocorrência histórica” (CHASIN, 2009, p. 154). Retém-se, assim, o caráter ontológico de sua crítica: a busca do entendimento efetivo da politicidade e de sua lógica imanente, reconhecendo sua origem e sua determinação social. 
A partir daí, da busca do entendimento do Estado e da política, que Marx a apreende de forma radicalmente diferenciada em relação ao pensamento político anterior. Forma que se evidencia em especial nesse texto, já que "é nas Glosas de 44 que temos a determinação de que o estado é produto da fraqueza da sociabilidade, não das melhores qualidades humanas" (CHASIN, 2009, p. 157). Com efeito, identifica Chasin que as linhas gerais da reflexão, antiga e moderna, sobre a política circunscrevem-se no "âmbito secularmente predominante da determinação ontopositiva da política, para a qual o atributo da politicidade não só integra o que há de mais fundamental do ser humanosocietário - é intrínseco a ele - mas tende a ser considerado como sua propriedade por excelência, a mais elevada, espiritualmente, ou a mais indispensável, pragmaticamente" (CHASIN, 2009, p. 64). Podemos citar, como exemplo da determinação positiva da política, de pronto, a determinação do homem, por Aristóteles, como zoon politikón. Ademais, podemos igualmente referenciar à reflexão hobbesiana, na qual, no "estado de natureza", isto é, deixado a si próprio, "a vida do homem é solitária, pobre, sórdida, embrutecida e curta" (HOBBES, 1983, p. 76), cabendo ao Estado, por conseguinte, a própria instituição da humanidade,

porque as leis de natureza (como a justiça, a equidade, a modéstia, a piedade, ou, em resumo, fazer aos outros o que queremos que nos façam) por si mesmas, na ausência do temor de algum poder [isto é, o Estado] capaz de leválas a ser respeitadas, são contrárias a nossas paixões naturais, as quais nos fazem tender para a parcialidade, o orgulho, a vingança e coisas semelhantes (HOBBES, 1983, p. 76).

A determinação ontopositiva, por conseguinte, "conduz à indissolubilidade entre política e sociedade, a ponto de tornar quase impossível, até mesmo para a simples imaginação, um formato social que independa de qualquer forma de poder político" (CHASIN, 2009, p. 64). Acompanhar detidamente essa reflexão converte-se em passo imprescindível na medida em que grande parte da tradição da ciência geográfica aí se inclui. Em Ratzel (1990, p. 76), por exemplo, temos exatamente a indissolubilidade da sociedade, em suas formas mais organizadas e complexas, com o Estado: "a sociedade que consideramos, seja grande ou pequena, desejará sempre manter sobretudo a posse do território sobre o qual e graças aos qual ela vive. Quando esta sociedade se organiza com esse objetivo, ela se transforma em Estado". E, ainda mais, posto que mesmo em seus momentos mais avançados, apresenta como télos último a instituição efetiva da cidadania e de um modelo cívico, ainda que numa noção ampliada destes ${ }^{140}$.

${ }^{140}$ Cf. Milton SANTOS, 2002. 
A reflexão marxiana, enfim, direciona-se em sentido essencialmente diverso: àquilo que Chasin denominou de determinação ontonegativa da politicidade, "donde é ontonegativa, precisamente, porque exclui o atributo da política da essência do ser social, só o admitindo como extrínseco e contingente ao mesmo, isto é, na condição de historicamente circunstancial" (CHASIN, 2009, p. 64). Rompe-se a identificação imediata entre homem e política ou entre sociedade e estado, que passam a ser entendidos como predicados existentes em momentos específicos do ser social: aqueles nos quais a autodeterminação se põe enquanto impossibilidade. Mais adiante (quarto capítulo) pretendemos abordar e desdobrar tal questão. No momento, registre-se a inversão fundamental efetivada por Marx neste momento, isto é, da política enquanto "predicado típico do ser social, apenas e justamente, na particularidade do longo curso de sua préhistória" (CHASIN, 2009, p. 64). A referência de Chasin aqui é, explicitamente, a passagem em que Marx caracteriza as sociedades de classes como o âmbito da préhistória.

Em suma, a partir dos escritos desse período, e desdobrando-se e alargando-se por seus estudos sobre a sociabilidade do capital e suas lutas de classes, temos que

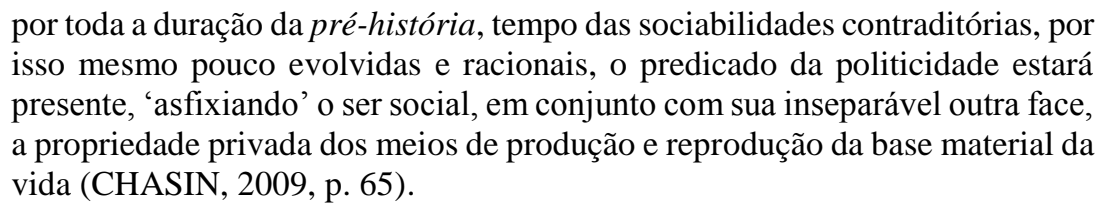

No próximo tópico, e no capítulo quatro, incorporando as problematizações de outras obras de Marx, abordamos questões acerca da propriedade privada e da divisão social do trabalho.

\subsection{A CRÍTICA DA ECONOMIA POLÍTICA: A ANALÍTICA DA TOTALIDADE E A ATIVIDADE SENSÍVEL}

A crítica ontológica da economia política, última do itinerário iniciado com o manuscrito Crítica da filosofia do direito de Hegel, explicita-se, pela primeira vez, em outro conjunto não publicado de escritos, que na sequência de nossa argumentação passa a ocupar um papel decisivo: os Manuscritos econômico-filosóficos, já abordados, em certos aspectos, na seção "A prioridade da objetividade" deste capítulo. Trata-se de um momento fundamental, não apenas porque Marx a ela se dedica, de maneira central, ao 
longo de toda sua existência, mas também pois, alargando e desdobrando as críticas anteriores, registram a instauração completa de uma nova concepção acerca do ser dos homens e da realidade em geral, isto é, representa a constituição de uma ontologia do ser social, fundada numa ontologia geral.

Nesse sentido, vale perceber que na crítica à filosofia especulativa, e a consequente determinação da teoria como reprodução ideal do movimento real (isto é, já na Crítica de 43), temos "sua ruptura antitética com o pensamento especulativo, a qual, resumida a si, é somente um passo unilateral, na medida em que a meta cognitiva do sujeito é replasmada por inteiro, sem que, todavia, o próprio sujeito seja redeterminado". Mesmo que, no tocante aos objetos tenha-se a assertividade de seu reconhecimento como "a malha sólida de suas próprias lógicas. Contudo, a natureza dos mesmos não é, conceitualmente, recomposta ou esclarecida". Nesse momento, afirma ainda Chasin, Marx mantém-se no quadro das reflexões tradicionais sobre as noções de sujeito e objeto, que parecem "se facear como simples exterioridades" (CHASIN, 2009, p. 90-1). Esta redeterminação de sujeito e objeto virá a emergir em 1844, no seio de sua pugna com os economistas clássicos.

Com efeito, vimos com Enguita, na discussão sobre a crítica da política, que uma concepção dualista é ainda explícita no artigo "Crítica da fillosofia do direito de Hegel. Introdução", escrito meses após a Crítica de 43 e em relação ao qual já se realizam alguns avanços - como a superação da propositura da anulação política da propriedade privada. Ali, a crítica ainda é vista como originada pela filosofia, a cabeça da revolução, enquanto o proletariado (cuja identificação consiste em outro inegável avanço) é perspectivado como seu coração, seu elemento passivo. O mesmo Enguita identifica, acerca desse ponto, que "os Manuscritos econômico-filosóficos, escritos em Paris entre abril e agosto de 1844, representam um novo passo no abandono da autossuficiência e, principalmente, da autogênese da teoria revolucionária, da crítica" (ENGUITA, 1993, p. 66) ${ }^{141}$. Da mesma forma, Chasin afirma, sobre a determinação conceitual de sujeito e objeto, que "o tratamento diferenciado dos mesmos só virá a emergir, de modo explícito e elaborado, nas páginas dos Manuscritos econômico-filosóficos e de A ideologia alemã. Os sujeitos,

\footnotetext{
${ }^{141}$ Celso FREDERICO (1995, p. 127) aponta para uma "ruptura decisiva na evolução intelectual de Marx" presente nos Cadernos de Paris e nos Manuscritos econômico-filosóficos. Por fim, é conhecida a já antiga caracterização de István MÉSZÁROS (2006), desse texto, como uma síntese in statu nascendi.
} 
então, serão determinados como os homens ativos e os objetos como atividade sensível" (CHASIN, 2009, p. 91). Dedicaremos esta seção a tais questões.

Iniciemos por problematizar os elementos mais imediatos, digamos, os "momentos” que levaram Marx a tal reconcepção em poucos meses. De início, é inegável a importância do primeiro contato mais sistematizado com a economia política, entendido como base para o entendimento das diversas formas de alienação ${ }^{142}$, conforme proposto nos artigos publicados nos Anais franco-alemães (constatamos a presença desse vínculo em "Sobre a questão judaica", por exemplo) e retomado logo na abertura dos Manuscritos: "será encontrado o fundamento, no presente escrito, da conexão entre a economia nacional e o Estado, o direito, a moral, a vida civil etc., na medida em que a economia nacional mesma, ex professo, trata destes objetos" (MARX, 2004, p. 19) ${ }^{143}$. Com efeito, "podemos chamar os Manuscritos de Paris de um sistema in statu nascendi, pois é neles que Marx explora sistematicamente, pela primeira vez, as implicações de longo alcance de sua ideia sintetizadora - 'a alienação do trabalho' - em todas as esferas da atividade humana" (MÉSZÁROS , 2006, p. 23). Ao invés de qualquer tipo de economicismo, portanto, o confronto de Marx com os economistas políticos corresponde ao entendimento do mundo enquanto uma totalidade hierarquizada.

Nesse sentido, o contato com os economistas não apenas permitiu a Marx aprofundar o conhecimento da sociedade civil e da economia capitalista, como facultou uma apreensão mais ampla da própria dinâmica do ser social:

\begin{abstract}
Sua negação da alienação nos escritos anteriores estava centrada, como vimos, na crítica das instituições existentes e das relações jurídico-políticas, e o 'trabalho' só surgia negativamente, como uma determinação ausente da posição do indivíduo na 'bügerliche Gesellschaft'. /.../. Antes dos Manuscritos de 1844 o fator econômico só surgia como um aspecto vagamente definido das relações sociopolíticas. Mesmo o autor dos artigos de A questão judaica e da Crítica da filosofia do direito de Hegel não percebia a importância ontológica
\end{abstract}

${ }^{142}$ E que representa, em certa medida, a continuidade da crítica a Hegel (diretamente retomada, e pela primeira vez em uma perspectiva mais global, ao final do texto) na medida em que "toda caracterização hegeliana da sociedade civil na Filosofia do direito estava baseada nos ensinamentos da economia clássica. A incursão nessa ciência, portanto, permitia a Marx dar sequência ao combate a Hegel de modo diferente aos Manuscritos de Kreuznach, sendo mais objetivo, descendo às fontes, por ele até então desconhecidas, de seu adversário" (FREDERICO, 1995, p. 131). Do mesmo modo, vale lembrar com John Bellamy Foster (2005, p. 101), constitui a busca do entendimento dos problemas materiais enfrentados quando da experiência na Gazeta Renana, em especial no tocante à questão do roubo da lenha: "Marx, todavia, acabaria por concluir que todos os seus argumentos sobre a lei racional e o direito costumeiro haviam falhando [sic] em expor os motivos deste inexorável processo de expropriação em benefício dos proprietários das florestas. As respostas jaziam, em vez disso, na economia política, cujo estudo ele encamparia com fervor sem igual /.../".

${ }^{143}$ Vale perceber, conforme indicado pelo tradutor da edição brasileira que o termo " "economia nacional" diz respeito, dependendo do contexto, tanto ao sistema econômico quanto às suas teorizações" (cf. MARX, 2004, nota 1). 
fundamental da esfera da produção, que aparecia em seus escritos na forma de referências bastantes genéricas às 'necessidades' (Bedürfnisse) em geral. Consequentemente, Marx era incapaz de apreender de maneira ampla a complexa hierarquia dos vários tipos e formas de atividade humana: suas interrelações recíprocas em um todo estruturado (MÉSZÁROS, 2006, p. 79).

A apreensão da realidade social enquanto uma totalidade hierarquizada $e$ estruturada assoma, nesse momento, na obra marxiana, a partir do exame mais cuidadoso dos economistas clássicos: "tudo isso é bastante diferente nos Manuscritos de 1844" (MÉSZÁROS , 2006, p. 79), nos quais a produção, a atividade humana passa a desempenhar uma importância ontológica fundamental para a estruturação das interrelações recíprocas entre as esferas da vida humana. É o mesmo que indica Chasin: "a crítica ontológica da economia política, em busca da 'anatomia da sociedade civil', leva à raiz, que impulsiona pelo nexo intrincado das coisas, materialmente, à analítica da totalidade" (CHASIN, 2009, p. 77). No que se põe como imprescindível perceber a ausência de qualquer forma de economicismo ou reducionismo da realidade à esfera econômica:

posta em andamento, a crítica ontológica da economia política, ao contrário de reduzir ou unilateralizar, induz e promove a universalização, estendendo o âmbito da análise desde a raiz ao todo da mundaneidade, natural e social, incorporando toda gama de objetos e relações (CHASIN, 2009, p. 77).

Tal compreensão se torna possível na medida em que, ressaltando o caráter ontológico desta terceira crítica, duas condições fundamentais se põem: a maturação do objeto concreto e a possibilidade de sua apreensão pela economia clássica, ainda em seu “período áureo e legítimo" (CHASIN, 2009, p. 116). Isto é, quanto a este segundo ponto, "os clássicos da Economia Política não desejavam, com seus estudos, constituir simplesmente uma disciplina científica entre outras", mas, de maneira concreta, "almejavam compreender o modo de funcionamento da sociedade que estava nascendo das entranhas do mundo feudal", na medida em que, inclusive, "não se colocavam como ‘cientistas puros', mas tinham claros objetivos de intervenção política e social” (NETTO; BRAZ, 2008, p. 17), no sentido exatamente de contribuir para a emersão e consolidação desta nova sociabilidade.

Enquanto representantes, ou mesmo membros (como é o caso de David Ricardo), da classe (a burguesia) que se contrapunha à ordem existente (feudal ou de traços feudais), na busca de constituição de uma ordem historicamente nova (a sociedade burguesa, capitalista), os economistas clássicos mantinham as "condições subjetivas" da objetividade científica até a emergência do movimento do proletariado urbano: "o solo e o tempo da objetividade científica, suscitada e favorecida pela lógica do capital, se 
desenrolaram, portanto, desde os embates contra o regime antigo até as franjas do desafio posto pela perspectiva humano-societária do trabalho" (CHASIN, 2009, p. 116).

De outro lado, tais pensadores situam-se no ponto em que afloram igualmente as "condições objetivas" dessa objetividade, ou seja, o próprio objeto se explícita concretamente com o desenvolvimento do modo de produção capitalista na Inglaterra. Antes de problematizar o desaparecimento das citadas "condições subjetivas" para a burguesia (e seu consequente deslocamento para a perspectiva do trabalho), vale reter a questão do desenvolvimento histórico e ontológico das próprias categorias que são reproduzidas pelo pensamento. Isto é, as categorias da Economia Política "são ontológicas na medida em que têm existência real, histórico-concreta: elas são formas, modos de existência do ser social, que funcionam e operam efetivamente na vida em sociedade, independentemente do conhecimento que tenham os homens a seu respeito" (NETTO; BRAZ, 2008, p. 54) e, por suposto, é o desenvolvimento real destas categorias que enseja sua compreensão - não se compreende aquilo que não se põe efetivamente -, “de modo que a maturação ou desenvolvimento, a plena entificação ou atualização do objeto é fundamental na relação cognitiva; a presença histórica de seu corpo maturado faculta, de seu pólo, o conhecimento, ao passo que em graus imaturados atua como obstáculo ou provoca obnubilação" (CHASIN, 2009, p. 119).

Nesse sentido, Marx pontuará que é o desenvolvimento do capitalismo, a forma mais complexa e desenvolvida da produção humana, que permitirá o próprio deslindamento desta, na medida em que se explicita e desenvolve sua categoria fundamental: o trabalho. Em seus termos:

o trabalho parece ser uma categoria muito simples. E também a representação do trabalho nesse sentido geral - como trabalho em geral - é muito antiga. Entretanto, concebido economicamente nessa simplicidade, o 'trabalho' é uma categoria tão moderna como o são as relações que engendram essa abstração (MARX, 1982, p. 16).

O trabalho, enquanto conceito, abstração, isto é, enquanto reprodução na forma de pensamento de uma realidade concreta, é uma possibilidade engendrada por determinadas relações, sendo que ambas (concepção e relações) são modernas. E mais, continua Marx, o mérito da apreensão do trabalho enquanto abstração (um "enorme progresso") corresponde a Smith, "que rejeitou toda determinação particular da atividade criadora de riqueza, considerando apenas o trabalho puro e simples, isto é, nem o trabalho industrial, nem o trabalho comercial, nem o trabalho agrícola, mas todas essas formas de trabalho" (MARX, 1982, p. 16). Para, na sequência, acentuar a raiz social, as relações 
modernas, que possibilitam a Smith esta compreensão, em dois aspectos: o próprio desenvolvimento dos tipos de trabalho ${ }^{144}$ e o tipo específico de sociedade que torna os homens indiferentes em relação à atividade que realizam ${ }^{145}$.

Tal questão retornará ao abordamos a individuação moderna. Por enquanto, é essencial reter a apreensão marxiana da "sociabilidade como condição de possibilidade do pensamento", isto é, que "verdadeiras ou falsas, as representações dos indivíduos, os únicos dotados de capacidade espiritual, brotam sempre do terreno comum do intercâmbio social" (CHASIN, 2009, p. 105 e 107). Concretamente, postos em solo e condições específicas, "os verdadeiros economistas têm o mérito de elaborar conceitualmente a matéria viva da atividade humana, descrevendo a articulação funcional do sistema produtivo do capital, embora cometendo a grave incorreção de estabelecer como eterno o complexo categorial que o identifica" (CHASIN, 2009, p. 116), sentido no qual se explícita mais uma vez o caráter essencial da crítica ontológica: é crítica de uma teoria (dos seus erros e das raízes desses erros) e, igualmente, da realidade que esta é capaz de reproduzir conceitualmente e que a sustenta. E é esta teoria que, socialmente enraizada de forma dupla (objetiva e subjetivamente), potencia a Marx, pelo desvendamento da categoria mais abstrata da produção material, do "puro trabalho", compreender sua centralidade na organização da vida e, portanto, a realidade como uma totalidade. O possibilita (tal como Feuerbach), no entanto, no quadro exato de sua superação, isto é, da percepção de sua vinculação com uma prática social e histórica específica.

A correta identificação desses limites da economia clássica nos permite compreender outra determinação fundamental (complementar) da emergência do pensamento marxiano - sua vinculação com a perspectiva humano-societária emergente do trabalho, ou seja, a associação de Marx com o movimento operário como condição de possibilidade da apreensão da lógica do ser social. Para além do contato, digamos, teórico,

\footnotetext{
144 "A indiferença em relação ao gênero de trabalho determinado pressupõe uma totalidade muito desenvolvida de gêneros de trabalho efetivos, nenhum dos quais domina os demais. Tampouco se produzem abstrações mais gerais senão onde existe o desenvolvimento concreto mais rico, onde um aparece como comum a muitos, comum a todos. Então já pode ser pensado somente sob uma forma particular" (MARX, 1982, p. 16-7).

145 "Por outro lado, essa abstração do trabalho em geral não é apenas o resultado intelectual de uma totalidade concreta de trabalhos. A indiferença em relação ao trabalho determinado corresponde a uma forma de sociedade na qual os indivíduos podem passar com facilidade de um trabalho para outro e na qual o gênero determinado de trabalho é fortuito, e, portanto, é-lhes indiferente" (MARX, 1982, p. 17).
} 
com os economistas, é central, para a reconcepção supracitada, a associação mais efetiva de Marx com os círculos operários e socialistas franceses ${ }^{146}$. É esta que permite ao filósofo alemão, em contraposição à economia clássica (que apenas enfatiza a determinação positiva do trabalho) evidenciar sua face negativa, quando inserida em específicos ordenamentos sociais, e o grifo é todo de Marx: "a economia nacional oculta o estranhamento na essência do trabalho porque não considera a relação imediata entre o trabalhador (o trabalho) e a produção. Sem dúvida. O trabalho produz maravilhas para os ricos, mas produz privação para o trabalhador" (MARX, 2004, p. 82).

Se a revolta dos tecelões da Silésia permite a Marx a visualização do movimento operário em germinação na Alemanha e, como vimos, resulta no artigo "Glosas críticas..." (já um avanço na crítica da política), a vinculação com o movimento francês, no bojo da tradição socialista revolucionária, permite o avanço mais geral da concepção de mundo marxiana. Ressaltar sua associação com o movimento operário não corresponde à busca de fatores externos que justifiquem determinada posição, mas, em realidade, à confirmação da própria teoria alcançada por Marx nesse momento (da centralidade da prática, da atividade sensível), na medida em que, enquanto "para o capitalista, as estruturas de apropriação e dominação vigentes aparecem como naturais, permanentes ou mesmo como o ápice do desenvolvimento histórico"; "na prática operária, o que é conjuntural expressa o status quo, as relações presentes de dependência e alienação" (IANNI, 1982, P. 35).

Com efeito, do próprio Marx se depreende tal raciocínio. Após expor, no Caderno I dos Manuscritos, o movimento da acumulação capitalista de acordo com os economistas ${ }^{147}$, afirma: "a economia nacional parte do fato dado e acabado da propriedade privada. Não nos explica o mesmo" (MARX , 2004, p. 79), ou seja, aponta para a característica central de que os economistas supõem aquilo que deveriam explicar, recaindo num suposto especulativo análogo ao de Hegel $^{148}$, posição teórica que se associa, diretamente, à prática capitalista. Percepção que o leva 1) a recusar o procedimento

\footnotetext{
146 "Os Manuscritos foram escritos na época em que Marx tomou contato pela primeira vez com o movimento operário real, com as associações e círculos de discussão dos operários franceses, e são múltiplas as passagens nos mesmos Manuscritos e, posteriormente, na Sagrada Família e na Ideologia alemã, que dão testemunho da profunda impressão que essa experiência produziu nele" (ENGUITA, 1993, p. 66).

147 "Partimos dos pressupostos da economia nacional. Aceitamos sua linguagem e suas leis" (MARX, 2004, p. 79)

148 “A economia, assim, é tão fantasmagórica como a filosofia especulativa de Hegel, pois também constrói um mundo às avessas, ao fazer do predicado (a propriedade privada) um sujeito que é o pressuposto de toda a reflexão econômica" (FREDERICO, 1995, p. 129).
} 
(especulativo) dos economistas: "não nos desloquemos, como [faz] o economista nacional quando quer esclarecer [algo], a um estado primitivo imaginário. Um tal estado primitivo nada explica. Ele simplesmente empurra a questão para uma região nebulosa, cinzenta"; e, por via de consequência, 2) propugnar: "nós partimos de um fato nacionaleconômico, presente": "o trabalhador se torna tanto mais pobre quanto mais riqueza produz, quanto mais a sua produção aumenta em poder e extensão" (MARX, 2004, p. $80)$.

A questão encaminha-se, assim, para a crítica, simultaneamente teórica e prática, da raiz da alienação - combatida em suas manifestações espirituais e políticas nas críticas anteriores -, isto é, a alienação do trabalho, desconsiderada pelos economistas políticos. Ao centrar-se na relação imediata entre o trabalhador e a produção, então, Marx situa a raiz de toda forma de opressão e exploração dos homens. Temos já, aqui, duas formas centrais da alienação: do trabalhador em relação ao resultado do seu trabalho (que não lhe pertence) e em relação ao próprio trabalho. Quanto a esta, a alienação no ato da produção, a situação na qual "o trabalho é externo ao trabalhador, isto é, não pertence ao seu ser, que ele não se afirma, portanto, em seu trabalho, mas nega-se nele" (MARX, 2004, p. 82), desdobra-se:

\footnotetext{
Esta relação é a relação do trabalhador com a sua própria atividade como uma [atividade] estranha não pertencente a ele, a atividade como miséria, a força como impotência, a procriação como castração. A energia espiritual e física própria do trabalhador, a sua vida pessoal - pois o que é vida senão atividade - como uma atividade voltada contra ele mesmo, independente dele, não pertencente a ele. O estranhamento-de-si (Selbstentfremdung), tal qual acima o estranhamento da coisa (MARX, 2004, p. 83).
}

Explicitam-se, enfim, duas dimensões fundamentais da alienação humana, quais sejam: a propriedade privada e a divisão do trabalho; bem como a acentuação da sua inerente interligação: "a propriedade privada é, portanto, o produto, o resultado, a consequência necessária do trabalho exteriorizado, da relação externa (äusserlichen) do trabalhador com a natureza e consigo mesmo". Como complementa logo adiante, contrapondo-se mais uma vez à economia nacional, na medida em que nesta "a propriedade privada aparece como fundamento, como razão do trabalho exteriorizado" e, em realidade, "ela é antes uma consequência do mesmo, assim como também os deuses são, originariamente, não a causa, mas o efeito do erro do entendimento humano. Mais tarde esta relação se transforma em ação recíproca” (MARX, 2004, p. 84).

Este apartamento do homem em relação ao produto do seu trabalho configura "a relação do trabalhador com o produto do trabalho como objeto estranho e poderoso sobre 
ele. Esta relação é ao mesmo tempo a relação com o mundo exterior sensível, com os objetos da natureza como um mundo alheio que se lhe defronta hostilmente" (MARX, 2004, p. 83). Ou seja, tomando este último elemento, desdobra-se, por assim, dizer por toda a vida do trabalhador - opondo-lhe em relação ao próprio mundo em que vive. Tal consideração tem importância óbvia para nosso tema e para a geografia, demonstrando a assertividade da posição de Quaini, discutida anteriormente, sobre o caráter mais orgânico da relação entre o determinismo e o capitalismo, enquanto representação de uma condição real - a da alienação.

Com efeito, reconhecidas as duas alienações fundamentais - entre o homem e seu trabalho e o homem e o produto do seu trabalho - bem como suas relações, podem "ser desenvolvidas todas as categorias nacional-econômicas, e haveremos de reencontrar em cada categoria, como por exemplo a do regateio, da concorrência, do capital, do dinheiro, apenas uma expressão determinada e desenvolvida desses primeiros fundamentos" (MARX , 2004, p. 89). Pois, "quando arranca do homem o objeto de sua produção, o trabalho estranhado arranca-lhe sua vida genérica, sua efetiva objetividade genérica e transforma sua vantagem com relação ao animal na desvantagem de lhe ser tirado o seu corpo inorgânico, a natureza" (MARX , 2004, p. 85). Tais separações convertem o ser genérico do homem, por via de consequência, em "um ser estranho a ele, um meio da sua existência individual. Estranha do homem o seu próprio corpo, assim como a natureza fora dele, tal como a sua essência espiritual, sua essência humana" (MARX, 2004, p. 85). Estranha o homem em relação a si próprio e a todo o gênero humano - que se faz tão somente meio de subsistência do indivíduo isolado. Explicitam-se, assim, como os elementos efetivamente fundantes mesmo de toda a economia e, portanto, da sociabilidade capitalista.

Enquanto elemento mais diretamente associado à crítica da ciência geográfica, pode-se identificar, em primeiro lugar, que, distintamente da tradição geográfica estabelecida, conforme vimos, a natureza não se põe como o outro oposto ao homem como um fato dado, mas como um fato histórico e específico - o trabalho estranhado. Em segundo lugar, voltemos a perceber que a raiz de toda alienação se põe nesse momento básico: na separação do homem em relação ao seu trabalho e, por conseguinte, ao produto do seu trabalho. É crucial, portanto, antes de aprofundar estas relações com a teoria geográfica, compreender a dimensão latente nessa crítica radical (que vai à raiz) da alienação: a afirmação da atividade como raiz do próprio homem: pois o que é vida senão 
atividade, afirma laconicamente Marx em passagem supracitada. A crítica da economia política, resultando na instauração de uma perspectiva teórica que prima pela captação da totalidade, associa-se à crítica de todas as formas de alienação, a partir da compreensão de sua raiz ontológica.

Com efeito, György Lukács (2012, p. 284-5) já apontara, acerca dos Manuscritos, que sua "originalidade inovadora reside, não menos importante, no fato de que, pela primeira vez na história da filosofia, as categorias econômicas aparecem como as categorias da produção e da reprodução da vida humana, tornando assim possível uma exposição ontológica do ser social sobre bases materialistas". Abrimos esta seção com a constatação que é tão somente nestes manuscritos que se efetua a "redeterminação" de sujeito e objeto no seio da concepção marxiana. O elemento essencial dessa nova concepção é a compreensão da centralidade da atividade sensível.

Retomando o raciocínio, vimos que "ao postular a atividade do pensamento de rigor como reprodução teórica da lógica intrínseca ao objeto investigado, Marx apenas deu início - com inflexão decisiva e emblemática, é verdade - à composição de sua plataforma científica. Por certo, definiu a tarefa do sujeito e assinalou o locus da verdade" (CHASIN, 2009, p. 90). Ou seja, continuando com Chasin (2009, p. 90-1, e vale repor a citação completa), reconheça-se que sua fórmula do pensamento como a reprodução da lógica específica do objeto específico

\begin{abstract}
sintetiza, acima de tudo, sua ruptura antitética com o pensamento especulativo, a qual, resumida a si, é somente um passo unilateral, na medida em que a meta cognitiva do sujeito é replasmada por inteiro, sem que, todavia, o próprio sujeito seja redeterminado, ao passo que, em relação aos objetos, é feita uma grande e certeira alusão - são reconhecidos como a malha lógica de suas próprias lógicas. Contudo, a natureza dos mesmos não é, conceitualmente, recomposta ou esclarecida. Em realidade, nesse momento inicial, sujeito e objeto, porquanto sejam reivindicados em sua terrenalidade, não são ainda distinguidos, positiva e especificamente, das acepções correntes ou tradicionais, parecendo se facear como simples exterioridades. Pela carência de elaboração são categorialmente indeterminados, apenas de sua referência direta a entificações concretas, sugerindo, por assim dizer, figuras substantificadas um tanto vagas em sua distinção e autonomia. $\mathrm{O}$ tratamento diferenciado dos mesmos só virá a emergir, de modo explícito e elaborado, nas páginas dos Manuscritos econômico-filosóficos e de A ideologia alemã.
\end{abstract}

A argumentação é precisa, e quase dispensa paráfrases. Mas vale o esforço em reter o essencial para nossa argumentação, inserida no âmbito de uma ciência que, em grande medida, nas suas práticas acadêmicas e escolares, permanece na consideração de sujeitos e objetos como entificações indeterminadas em sua autonomia e distinção, que continuam a parecer se facear como simples exterioridades: a redeterminação do sujeito 
e a recomposição conceitual e esclarecimento da natureza dos objetos, já reconhecidos como detentores de uma lógica imanente, compõem um segundo passo na dinâmica do pensamento marxiano, após a radical reivindicação da terrenalidade de sujeitos e objetos - o reconhecimento de ambos em sua objetividade fundante. Segundo passo que implica em superar a formulação intelectual imprecisa dos contornos do homem e da natureza e será efetivado entre os anos de 1844 e 1845, sintetizado nas duas obras citadas. São nessas obras que sujeitos e objetos serão recaracterizados: "Os sujeitos, então, serão determinados como os homens ativos e os objetos enquanto atividade sensível" (CHASIN, 2009, p. 91). Em outros termos, temos o andamento "em favor de uma ontologia na qual o ser só é reconhecido pela identificação à objetividade, em especial à objetividade social - enfim decifrada como atividade sensível, o que supera em larga escala os indicativos feuerbachianos" (CHASIN, 2009, p. 86). Enfim, pretendemos desdobrar agora "o que constitui o grande mérito e salto marxiano para além dos indicativos feuerbachianos, a precisa identificação da objetividade social - posta e integrada pelo complexo categorial que reúne sujeito e objeto sobre o denominador comum da atividade sensível" (CHASIN, 2009, p. 95).

Determinação dos homens enquanto seres ativos, isto é, capazes de uma adaptação ativa em relação ao meio, e dos objetos enquanto atividade sensível, enquanto produto da objetivação humana - o elemento central da nova ontologia marxiana: a identificação da objetividade social - articulação de sujeito e objeto no âmbito da atividade sensível. Interessante perceber que tal dimensão já se encontrava em certas passagens analisadas ao longo do capítulo, mas apenas agora pode ser expressa em sua radicalidade. É esse o teor fundamental da crítica a Feuerbach, contida na primeira tese Ad Feuerbach: "o principal defeito de todo o materialismo existente até agora (o de Feuerbach incluído) é que o objeto, a realidade, o sensível, só é apreendido sob a forma de objeto ou da contemplação, mas não como atividade humana sensível, como prática", de modo que "ele não apreende a própria atividade humana como atividade objetiva" (MARX; ENGELS, 2007, p. 533). Ou seja, reconhecer a atividade humana como atividade objetiva implica em alcançar a determinação da objetividade enquanto posta por essa atividade, que é sempre atividade social, e, portanto, enquanto objetividade social.

Nos Manuscritos econômicos-filosóficos, na sequência dos trechos nos quais Marx assenta a objetividade enquanto determinação primária de todos os tipos do ser, 
assevera a necessidade de se considerar a especificidade do ser social. Nesse sentido, assenta a permanente e necessária interação dos homens com os demais elementos da natureza: "a natureza é o corpo inorgânico do homem /.../. O homem vive da natureza significa: a natureza é o seu corpo, com o qual ele tem de ficar num processo contínuo para não morrer"; e reafirma mesmo o homem enquanto parte da natureza: "que a vida física e mental do homem está interconectada com a natureza não tem outro sentido senão que a natureza está interconectada consigo mesma, pois o homem é uma parte da natureza" (MARX; ENGELS, 2007, p. 533).

Nessa interação permanente, porém, se põe igualmente sua especificidade em relação à natureza, seu corpo inorgânico, sua diferença específica: a atividade humana é atividade genérica - é produtora do gênero humano: "o homem não é apenas ser natural, mas ser natural humano, isto é, ser existente para si mesmo, por isso, ser genérico, que, enquanto tal, tem de atuar e confirmar-se tanto em seu ser quanto em seu saber" (MARX, 2004, p. 128). Assim, é na atividade vital - a atividade garantidora da vida objetiva - de uma espécie que reside a essência dessa espécie animal, em seus termos: "no modo da atividade vital encontra-se o caráter inteiro de um species, seu caráter genérico, e a atividade consciente livre é o caráter genérico do homem" (MARX, 2004, p. 84). Quando Chasin assevera, então, que os sujeitos são determinados enquanto homens ativos, referese exatamente à caracterização da atividade consciente livre.

Um primeiro caráter dessa atividade, enquanto consciente e livre, é o fato de não ser uma atividade instintiva, naturalmente determinada, pois "o homem faz da sua atividade vital mesma um objeto da sua vontade e da sua consciência", enquanto "o animal é imediatamente um com a sua atividade vital" (MARX, 2004, p. 84). Não se trata de uma atividade naturalmente dada, espontaneamente posta na exata medida em que, por exemplo, quando o faz, "o animal produz apenas sob o domínio da carência física imediata, enquanto o homem produz mesmo livre da carência física, e só produz, primeira e verdadeiramente, na [sua] liberdade [com relação] a ela" (MARX, 2004, p. 85). A atividade humana, então, não é nem instintivamente determinada nem visa a satisfação tão somente das necessidades físicas imediatas: "o animal forma apenas segundo a medida e a carência da species à qual pertence, enquanto o homem sabe produzir segundo a medida de qualquer species, e sabe considerar, por toda a parte, a medida inerente ao objeto; o homem também forma, por isso, segundo as leis da beleza” (MARX, 2004, p. $85)$. 
Desdobremos esses aspectos. Enquanto atividade consciente, a ação humana rompe com a circularidade da vida e atividade animais ${ }^{149}$ - que atua buscando tãosomente sua reprodução e de sua prole. Daí a caracterização básica da esfera do ser orgânico, conforme acentua Lukács. Nesse âmbito, a atividade animal é, apenas, de apropriação dos demais elementos da natureza que garantam sua sobrevivência e reprodução.

A atividade propriamente humana, por sua vez, caracteriza-se não apenas pela apropriação, pelo consumo imediato das demais formas do ser. Como define em texto intimamente vinculado aos Manuscritos, na medida em que os homens, como qualquer ser vivo, apresentam um conjunto delimitado de necessidades, "o primeiro ato histórico é, pois, a produção dos meios para a satisfação dessas necessidades” (MARX; ENGELS, 2007, p. 33). Ao invés do puro consumo, a produção dos meios para este, "isto significa que a atividade vital humana, já nas suas formas mais elementares, não se caracteriza pelo simples consumo dos objetos que satisfaçam necessidades, mas, sim, pela produção dos meios que possibilitem essa satisfação" (DUARTE, 2013, p. 26). Ao atuar de maneira consciente os homens criam uma nova realidade, objetivam suas ideias, no interior de uma determina prática social. Nesse sentido, a atividade vital humana instaura uma dinâmica própria entre apropriação e objetivação que gera, por sua vez, o próprio processo histórico: a apropriação da natureza e sua transformação em fenômenos culturais representando estes a objetivação da atividade - que, por sua vez, passarão a ser apropriados pelos homens num processo sem fim.

Daí Marx e Engels referirem-se à "produção da própria vida material” como "um ato histórico, uma condição fundamental de toda a história, que ainda hoje, assim como há milênios, tem de ser cumprida diariamente, a cada hora, simplesmente para manter os homens vivos" e defenderem que, apesar da aparente simplicidade desse reconhecimento, "a primeira coisa a fazer em qualquer concepção histórica é, portanto, observar este fato fundamental em toda a sua significação e em todo o seu alcance e a ele fazer justiça" (MARX; ENGELS, 2007, p. 33). Nesse sentido, o fundamental é reconhecer que, além de não ser naturalmente posta, a atividade humana representa “o engendrar prático de um

\footnotetext{
${ }^{149}$ Mesmo as "formas animais elementares de objetivação e apropriação são determinadas e limitadas pelo organismo do animal, isto é, pela objetividade biológica da espécie, que lhe é transmitida geneticamente em seu organismo" (DUARTE, 2013, p. 27)
} 
mundo objetivo, a elaboração da natureza inorgânica é a prova do homem enquanto um ser genérico consciente" (MARX, 2004, p. 85).

O homem, assim, não apenas está em permanente interação com natureza, como vimos, razão pela qual já fora considerada seu corpo inorgânico, mas, também, se afirma na própria elaboração da natureza inorgânica, que representa sua duplicação objetiva, sua vida genérica tornada objeto - daí Marx referir-se à objetivação, à atividade manifesta na forma de objeto. A objetividade ganha, assim, o novo estatuto de objetividade social. Em seus termos, "o objeto do trabalho é portanto a objetivação da vida genérica do homem: quando o homem se duplica não apenas na consciência, intelectual[mente], mas operativa, efetiva[mente], contemplando-se, por isso, a si mesmo num mundo criado por ele" (MARX, 2004, p. 85). Ou então, em outro momento, ao se referir à atividade sensível dos homens, destaca que "é essa atividade, esse contínuo trabalhar e criar sensíveis, essa produção, a base de todo o mundo sensível, tal como ele existe agora" (MARX; ENGELS, 2007, p. 31).

De outro lado - aspecto já presente quando se afirma que a produção humana rompe a circularidade da atividade animal - a produção do mundo objetivo implica sua autoprodução do homem: a essência humana se desdobra, se confirma, objetivamente, o que torna possível a riqueza subjetiva. Nos Manuscritos a dimensão é assim equacionada:

[é] apenas pela riqueza objetivamente desdobrada da essência humana que a riqueza da sensibilidade humana subjetiva, que um ouvido musical, um olho para a beleza da forma, em suma as fruições humanas todas se tornam sentidos capazes, sentido que se confirmam como forças essenciais humanas, em parte recém cultivados, em parte recém engendrados (MARX, 2004, p. 110).

E sintetiza Newton Duarte: "o ser humano, ao produzir os meios para a satisfação de suas necessidades básicas de existência, ao produzir uma realidade humanizada pela sua atividade, humaniza a si próprio, posto que a transformação objetiva é acompanhada da transformação subjetiva" (DUARTE, 2013, p. 26). A superação da concepção que dicotomiza objetividade e subjetividade é exposta aqui em seu ponto nuclear: a atividade humana unifica os dois pólos. Trata-se de aspecto de tal radicalidade que suas consequências serão desdobradas em diversos aspectos - por exemplo, quanto à questão do que Chasin denomina a fundamentação ontoprática do conhecimento, e que abordaremos no próximo capítulo. Por enquanto, vale reter o aspecto de que essa dinâmica é geradora do processo histórico, da própria humanização. Isto é, ao satisfazer suas necessidades, uma primeira transformação dos próprios homens - aspecto já presente em citações anteriores quando reconhecemos o caráter de liberdade da atividade humana 
consciente - é a produção de novas necessidades. "O segundo ponto é que a satisfação dessa primeira necessidade, a ação de satisfazê-la e o instrumento de satisfação já adquirido conduzem a novas necessidades - e essa produção de novas necessidades constitui o primeiro ato histórico" (MARX; ENGELS, 2007, p. 33).

Assim, a relação entre apropriação e objetivação estabelece uma dinâmica que fundamenta a própria história, a dinâmica atividade-carecimento, que evidencia

\begin{abstract}
que o desenvolvimento da atividade prático-material, sendo o motor da transformação das condições objetivas de existência dos indivíduos, é, também, o motor do processo de transformação das subjetividades, através da transformação de suas necessidades. O complexo essencial através do qual se desdobra esse processo e que configura o núcleo do movimento autoconstitutivo do ser social, do devir humano do homem e do forjar-se da individualidade humana, está aqui exposto por Marx na forma da dialética entre atividade e carecimento (TEIXEIRA, 1999, p. 221).
\end{abstract}

Tal dinâmica, conforme exposta anteriormente, assenta definitivamente a originalidade do pensamento marxiano, a partir da compreensão do complexo e contraditório processo de humanização, de produção humana do mundo e de si, no qual o desenvolvimento da subjetividade humana emerge como eixo central. Estão postas as bases, assim, para estabelecer o diálogo com a crítica da geografia e da sua concepção de homem, sumariadas no primeiro capítulo, intento ao qual nos dedicamos na sequência. 


\section{CAPÍTULO 3 - GEOGRAFIA, COMPLEXOS E DETERMINAÇÕES CATEGORIAIS}

O objetivo deste capítulo, a partir da exposição do momento constituinte do pensamento marxiano, é extrair as determinações categoriais nucleares que nos permitem refletir sobre a geografia do processo de individuação - incorporar o conjunto das problematizações desenvolvidas no capítulo anterior à temática específica em tela (a individualidade humano-social e sua geografia) e ao debate tracejado no primeiro capítulo (acerca da crítica à tradição do pensamento geográfico institucionalizado). Demarcaremos ao longo do capítulo, mas vale afirmar logo de saída, que lidamos, ainda mais neste momento, com diversas problemáticas filosóficas, eixos de debates ricos, complexos e diversificados ${ }^{150}$. O objetivo não pode ser o de sumariar o debate, mas depreender as posições mais adequadas (possíveis) a partir da análise (realizada) do pensamento marxiano.

Nesse sentido, iniciamos por demarcar alguns desdobramentos da verdadeira revolução teórica representada pela apreensão (discutida no último item do capítulo anterior) da centralidade sensível na conformação do ser social, isto é, na produção da objetividade social e, por e através desta, do próprio ser social (e do entendimento, portanto, deste como um ser que se autoconstitui). Completamos essa discussão com um breve excurso sobre a relação entre ontologia e ciência, buscando sua configuração na posição marxiana (e explicitada por Lukács, Chasin e, mais recentemente, problematizada por Ivo Tonet) como forma de superar a leitura "epistemologista" consagrada no processo de renovação, bem como demarcar as especificidades de cada forma de reflexão - a ontologia no âmbito da filosofia e a geografia no da ciência. Tal trajeto permite demarcar aspectos relacionados ao campo disciplinar da ciência geográfica, enquanto ciência particular, momento no qual interagimos com diferentes geógrafos situados no campo marxista e alguns "tradicionais". Mantendo e desdobrando esta interlocução, concluímos o capítulo com a discussão do complexo geográfico, a partir da inspiração no reconhecimento lukácsiano do ser social como um complexo de complexos. Retomamos,

\footnotetext{
${ }^{150}$ Por exemplo, "o que Marx concebe por ciência e filosofia e suas relações recíprocas, desde há muito está constituído em questão decisiva e delicada. A ponto da maneira pela qual seja entendida possa ser tomada como importante indicativo da qualidade do marxismo produzido" (CHASIN, 1987, p. 43).
} 
assim, a problematização sobre a totalidade e os complexos, discutindo a questão da dimensão espacial da realidade, da geografia como um complexo.

\subsection{A FUNDAMENTAÇÃO ONTOPRÁTICA DO CONHECIMENTO E A GÊNESE DO REFLEXO CIENTÍFICO}

Massimo Quaini (1979, p. 40), exatamente em sua abordagem a respeito do surgimento da base do que chama de materialismo histórico (a crítica materialista à dialética especulativa), adverte: "Não são evidentemente os aspectos filosóficos da metodologia materialista de Marx os que nos interessam aqui - mesmo não sendo possível, num certo sentido, prescindir deles - mas antes as suas aplicações". Apropriando-nos de sua advertência, objetivamos propor, nesta seção, ponderações, ainda fundadas nas reflexões marxianas expostas acima e nos apropriando de indicações, em especial, de Gyorgy Lukács e José Chasin ${ }^{151}$, sobre a relação entre ontologia (filosofia) e ciência. Tais reflexões e desdobramentos impõem-se a nós, neste momento, dada a verdadeira ruptura em relação a toda a tradição filosófica ocidental que se depreende dos escritos marxianos analisados e da posição teórica instituída e, mais ainda, seu caráter verdadeiramente contrário no tocante às posições hegemônicas no cenário intelectual contemporâneo ${ }^{152}$, na medida em que "a tentativa de basear o pensamento filosófico do mundo sobre o ser se depara com resistências de muitos lados. Os últimos séculos do pensamento filosófico foram dominados pela teoria do conhecimento, pela lógica e pela metodologia, e esse domínio está longe de ser superado" (LUKÁCS , 2010, p. 33). Com efeito, mesmo em relação à Quaini, autor que apresenta uma leitura profunda da obra marxiana e com o qual estabeleceremos ainda frutíferos pontos de intersecção, apontamos, momentos atrás, o equívoco em tomar como central da crítica marxiana à filosofia hegeliana a dimensão metodológica da especulação, ainda que reconheçamos, e isso é decisivo, que este elemento igualmente está presente em tal crítica.

${ }^{151}$ Recorremos também, nesse momento, a textos que objetivam explicitar ou desdobrar tematizações a partir de ambos filósofos, na medida em que o caráter incompleto de seus textos não nos garantissem a exposição efetiva das questões.

${ }^{152} \mathrm{Cf}$., por exemplo, quanto à manifestação deste cenário na ciência geográfica contemporânea, MORAES (2006). 
Nesse sentido, o predomínio da gnosiologia no ambiente intelectual e filosófico exerceu grande influência no bojo do próprio marxismo. Ao longo do século XX, diversas foram as lacunas ${ }^{153}$ do pensamento de Marx identificadas pelos mais distintos marxistas e marxismos. A reflexão a respeito da teoria do conhecimento, da gnosiologia ou, mais restritamente, da epistemologia, foi uma delas. Mais ainda, tais lacunas, em geral, foram "preenchidas" pela incorporação de matrizes teóricas substancialmente distintas, em sua essência, quando não explícita e radicalmente opostas ao cerne da teoria marxiana dentre elas, merece destaque a kantiana. Postura que, para além dos limites de todo ecletismo, não compreende que "a ausência de equacionamento convencional do assunto é apenas o sinal negativo da completa reconversão e resolução positivas que a matéria encontra na reflexão marxiana, ainda que só tratada ocasional e esparsamente" (CHASIN , 2009, p. 90). Daí, inclusive, o esforço em seguir o andamento da própria reflexão de Marx, pois, como vimos, "ao postular a atividade do pensamento de rigor como reprodução teórica da lógica intrínseca ao objeto investigado" Marx inicia, “com inflexão decisiva e emblemática", a "composição de sua plataforma científica", no que cabe destacar que tal fórmula "sintetiza, acima de tudo, sua ruptura antitética com o pensamento especulativo" (CHASIN , 2009, p. 90), ainda que tal dimensão apenas possa ser efetivamente compreendida com base em suas reflexões posteriores acerca da especificidade do ser social, com a centralidade da práxis. Em suma, enquanto, por exemplo, em Kant, temos uma subjetividade que, através das categorias a priori do entendimento, organiza o seu mundo ${ }^{154}$, no pensador comunista temos uma completa recolocação da "meta cognitiva do sujeito" - a apreensão dos entes efetivamente existentes, da "lógica da coisa" - na forma da apreensão mental da organização do mundo.

Em certa medida, Henri Lefebvre (1991, p. 49), em Lógica formal/Lógica dialética, explicita o cerne essencial da questão que aqui abordaremos quando inicia por reconhecer: "o conhecimento é um fato: desde a vida prática mais imediata e mais simples, nós conhecemos objetos, seres vivos, seres humanos". E um fato que se assenta na questão ontológica essencial a ser desenvolvida - a transitividade objetividade-

\footnotetext{
153 A lacuna em relação ao espaço, talvez, podemos incluir nestas.

${ }^{154}$ Mais à frente desdobraremos aspectos relacionados à sua filosofia idealista subjetiva, mas fique grifado o fundamental: "Na gnosiologia formulada por Kant o sujeito cognoscente, sempre transcendental, ocupa papel de destaque por ser quem cumpre a cada momento a síntese do conhecimento em relação à objetividade concreta. Tal propositura culmina na afirmação taxativa da incognoscibilidade da coisa em sim, uma vez que às funções sintética do pensamento caberia o papel último de articular, no plano do entendimento, as relações e propriedades do fenômeno" (FORTES, 2013, p. 30).
} 
subjetividade: "Em termos filosóficos, o sujeito (o pensamento, o homem que conhece) e o objeto (os seres conhecidos) agem e reagem continuamente um sobre o outro" (LEFEBVRE, 1991, p. 49). Isto é, como vimos, os homens atuam objetivamente ${ }^{155}$, no que se deparam com uma realidade objetiva com uma lógica interna própria cuja apreensão se torna condição da própria ação ${ }^{156}$. Em suma: “o sujeito e o objeto estão em perpétua interação; essa interação será expressa por nós com uma palavra que designa a relação entre dois elementos opostos e, não obstante, partes de um todo /.../; diremos, por definição, que se trata de uma interação dialética" (LEFEBVRE, 1991, p. 49).

A partir daí, Lefebvre recusa mesmo a possibilidade de um "problema do conhecimento": "é inegável que o conhecimento põe certos problemas; todavia, o conhecimento em si mesmo não é um problema, mas um fato" (LEFEBVRE, 1991, p. 50) que na especulação, na cisão do "indissoluvelmente ligado: os elementos do conhecimento, o sujeito e o objeto", converte-se em problema. E, nesse caso, insolúvel.

Com efeito, a metafísica, termina por negar alguma das características mais gerais do conhecimento humano, que é prático, social e histórico. Isto é, “em primeiro lugar, o conhecimento é prático. /.../. Tão-somente a prática nos põe em contato com as realidades objetivas" (LEFEBVRE, 1991, p. 49), um ser (que apenas pode ser imaginado) puramente passivo, deparar-se-ia com a realidade em "uma espécie de sonho; ele nem sequer imaginaria o que pode ser um conhecimento que penetra nas coisas e investiga o que elas são em si mesmas" (LEFEBVRE, 1991, p. 50), sendo este o caso quando o ser ativo se defronta com a realidade de forma prática. "Em segundo lugar, o conhecimento humano é social. Na vida social, descobrimos outros seres semelhantes a nós; eles agem sobre nós, nós agimos sobre eles e com eles" (LEFEBVRE, 1991, p. 50) e deles recebemos "- pelo exemplo ou pelo ensino - um imenso saber já adquirido". E, por fim, "todo conhecimento foi adquirido e conquistado", o que lhe atribui um caráter inerentemente histórico: "o que é verdadeiro para o indivíduo é igualmente verdadeiro para a humanidade inteira: o imenso lavor do pensamento humano consiste num esforço secular para passar da ignorância ao conhecimento" (LEFEBVRE, 1991, p. 50). Se essas são as características mais básicas do conhecimento, este passa a ser um "problema" quando elas são negadas explícita ou implicitamente:

155 “/.../ eu ajo sobre as coisas, exploro-as, experimento-as” (LEFEBVRE, 1991, p. 49).

${ }^{156}$ As coisas "resistem ou cedem à minha ação, revelam-se; eu as conheço e aprendo a conhecê-las" (LEFEBVRE, 1991, p. 49). 
Os metafísicos em questão esqueceram essa constatação primária do bom senso e da prática: estamos em relação com um mundo, com objetos, com seres vivos e humanos. Essa relação faz parte de nosso próprio 'ser'; nosso 'eu' não pode se isolar; não está fechado em si mesmo, fora do mundo e da natureza, ‘império num Império', seguindo a justa expressão de Spinoza (LEFEBVRE, 1991, p. 51).

A raiz última desse "esquecimento" já fora elucidada por Marx e Engels como a divisão entre trabalho material e espiritual - "a partir desse momento, a consciência pode realmente imaginar ser outra coisa diferente da práxis existente, representar algo sem representar algo real - a partir de então, a consciência está em condições de emanciparse do mundo" (MARX, ENGELS, 2007, p. 35). É quando o trabalho ideal, de planejamento da atividade e, por conseguinte, a fruição deste trabalho se separam do trabalho material propriamente dito, isto é, com a divisão social do trabalho, que a própria consciência está em condições de romper, cindir o que está dado na realidade: a relação inerente dos homens entre si e com o mundo, o permanente intercâmbio entre subjetividade e objetividade.

Também Chasin (2009, p. 98), condena “a própria teoria do conhecimento, que parte de acrítica separação ontológica entre sujeito e objeto como substâncias distintas, e se condena por isso à impossibilidade de encontrar a forma de seu enlace no saber". Ao tratar sujeito e objeto como "círculos inertes e excludentes", torna-se impossível chegarse à raiz mesma do conhecimento e, portanto, este se torna um "problema". A fim de superar tal unilateralismo, Chasin trata da transitividade entre objetividade $\mathrm{e}$ subjetividade, a partir de sua reunião no complexo da atividade sensível.

Retornamos, assim, ao ponto de crítica e superação do materialismo existente até Marx, e que encontra em Feuerbach uma de suas expressões sintéticas principais. Como vimos, "o materialismo abstrato de Feuerbach, apesar de toda a sua importância como refutação do sistema hegeliano, era todavia estático, de concepção aistórica e parecia não levar a lugar nenhuma. O seu humanismo carecia de um conceito de prática transformativa (práxis)” (FOSTER, 2005, p. 161). Em outros termos: “o materialismo antigo ignora por completo a qualidade da objetividade social, isto é, sua energia, sua atualização pela atividade sensível dos homens ou, simplesmente, desconhece sua forma subjetiva" (CHASIN, 2009, p. 97) Já vimos, também, que é este conceito de prática que se demarca da crítica de Marx à economia política. Aqui, portanto, se desdobra uma de suas consequências fundamentais. 
Nesse sentido, a dimensão fundamental da centralidade da atividade sensível, na teoria marxiana, é a radical afirmação da autoconstrução humana: "por sua essência ativa as individualidades humano-societárias, autoras de sua afirmação e de seu gênero, são como tais as efetivadoras de suas esferas próprias de objetividade e subjetividade" (CHASIN, 2009, p. 94). Objetividade e subjetividade são, assim, resgatadas da excludência na medida em que constada sua geratriz fundamental: a prática humana. Isto porque, numa palavra, prática é dação de forma ${ }^{157}$, daí Chasin referir-se à forma subjetiva da objetividade e apontar o passo seguinte - o pensamento como uma dimensão da prática, da relação entre subjetividade e objetividade: "para que possa haver dação sensível de forma, o efetivador tem primeiro que dispor dela em si mesmo, o que só pode ocorrer sob configuração ideal, evidenciando momentos distintos de um ato unitário", em suma, "pela mediação da prática, objetividade e subjetividade não resgatas de suas mútuas exterioridades", razão pela qual pode-se reconhecer a noção de transitividade: "uma transpassa ou transmigra para a esfera da outra, de tal modo que a interioridade subjetiva e exterioridade objetiva são enlaçadas e fundidas, plasmando o universo da realidade humano-societária - decantação de subjetividade objetivada ou, o que é o mesmo, de objetividade subjetividade" (CHASIN, 2009, p. 98) ${ }^{158}$.

Assim, é por argumento e razões ontológicas que Chasin refuta a "impossibilidade do conhecimento": "a impossibilidade de conhecer suprimiria a capacidade de confirmação do ser social, e um ser que não se confirma, sensivelmente, é um não-ser, isto é, um absurdo - o questionamento sobre a possibilidade do conhecimento se torna ocioso" (CHASIN, 2009, p. 101).

Com efeito, ao contrário, tal apreensão permite recentrar a questão e perceber a atividade do pensamento como intrínseca à prática humana, em duas dimensões essenciais: "a subjetividade proponente - teleologia, e a subjetividade receptora capacidade cognitiva" (CHASIN, 2009, p. 100), na medida em que "o ser humano precisa conhecer a natureza do objeto para poder adequá-lo às suas finalidades. Ou seja, para que o objeto possa ser transformado e inserido na 'lógica' da atividade humana, é preciso que o ser humano se aproprie de sua 'lógica' natural” (DUARTE, 2013, p. 28), numa palavra,

\footnotetext{
157 “/... efetivação humana de alguma coisa é dação de forma humana à coisa, bem como só pode haver forma subjetiva, sensivelmente efetivada, em alguma coisa" (CHASIN, 2009, p. 97).

${ }^{158}$ Karel Kosic (1976, p. 114), por exemplo, afirma: a práxis humana "é o cenário onde se opera a metamorfose do objetivo no subjetivo e do subjetivo no objetivo, ela se transforma no centro ativo onde se realizam os intentos humanos e onde se desvendam as leis da natureza".
} 
se aproprie (idealmente) da causalidade que compõe a legalidade específica do objeto. A questão gnosiológica, assim, deixa de ser tomada como ponto de partida, substituída pela determinação ontológica de quem é o ser que age e, para tanto, conhece. Isto é, o pensamento é apanhado "no complexo real onde se manifesta como força específica de um ser peculiar nos atos pelos quais este se confirma" (CHASIN, 2009, p. 102)

Desse modo, Marx aponta para a questão decisiva: a "do critério de verdade. E a resolução marxiana é, novamente, ontológica ou, mais precisamente, ontoprática" (CHASIN, 2009, p. 101): "a questão de saber se ao pensamento humano cabe alguma verdade objetiva não é uma questão da teoria, mas uma questão prática" (MARX; ENGELS, 2007, p. 533) inicia taxativamente a 2 Tese Ad Feuerbach, que, como sabido, conclui por considerar escolástica "a disputa acerca da realidade ou não-realidade do pensamento" (MARX; ENGELS, 2007, p. 533). Trata-se de uma escolástica pois, como vimos, cinde a realidade, desconsidera a essência ativa do ser que pensa. Isto é, obnubila que "toda vida social é essencialmente prática" e nos permite perceber que "todos os mistérios que conduzem a teoria ao misticismo encontram sua solução racional na prática humana e na compreensão dessa prática" (MARX; ENGELS, 2007, p. 534), conforme estabelece na menos citada 8 tese.

Podemos reconhecer, enfim, que há um deslocamento da questão gnosiológica tradicional, que afirma a impossibilidade do conhecimento, na medida em que

$$
\begin{aligned}
& \text { sob o rigor próprio à crítica ontológica, pela qual o conhecimento, como } \\
& \text { qualquer alvo de investigação, é determinado pela gênese e necessidade de sua } \\
& \text { entificação. Pertinência e superioridade de tratamento, desde logo, porque não } \\
& \text { isola saber de fazer, o que equivale a não separar o pensamento como predicado } \\
& \text { do ser que pensa (CHASIN, 2009, p. 102). }
\end{aligned}
$$

E o ser que pensa o faz em condições concretas e com objetivos determinados, dos quais se destacam, enquanto necessidade primária, aqueles conectados à produção material dos homens, à sua prática: "a linguagem nasce, tal como a consciência, do carecimento, da necessidade de intercâmbio com outros homens. Desde o início, portanto, a consciência é já um produto social e continuará sendo enquanto existirem homens" (MARX; ENGELS, 2007, p. 35). A remissão marxiana à prática social permite dilucidar, em primeiro lugar, o pensamento enquanto uma forma através da qual os homens se apropriam do mundo. Nesse sentido, a subjetividade (proponente e receptora), enquanto momento da prática humana, no processo inexorável de relacionar-se com os outros homens e as demais formas de ser, explicita-se como uma das dimensões da apropriação 
humana do mundo, uma das forças essenciais dos homens - a força da abstração, conforme configurado nos Manuscritos:

Cada uma das suas relações humanas com o mundo, ver, ouvir, cheirar, degustar, sentir, pensar, intuir, perceber, querer, ser ativo, amar, enfim, todos os órgãos da sua individualidade, assim como os órgãos que são imediatamente em sua forma como órgãos comunitários, são no seu comportamento objetivo ou no seu comportamento para com o objeto a apropriação do mesmo (MARX, 2004, p. 108).

A apropriação efetuada por essa força essencial específica, por este órgão da individualidade humana, corresponde à apropriação ideal, à "reprodução intelectual de entidades reais, o que se confirma pelo caráter ontológico das abstrações produzidas" (CHASIN, 2009, p. 123). Trata-se, então, da expressão, na forma de ideias, de elementos presentes no mundo objetivo, com o qual os homens se relacionam, ou seja, "em sua determinação ontológica, as abstrações admitidas por Marx são representações gerais extraídas do mundo real" (CHASIN, 2009, p. 123). Enquanto Chasin grifa a proveniência objetiva das abstrações, vale, para concretizar sua caracterização, reter a dimensão da generalidade, isto é, em especial quando se destaca a noção, também explicitada por Marx, de abstrações razoáveis, "quando retém e destaca aspectos reais, comuns às formas temporais de entificação dos complexos fenomênicos considerados. A razoabilidade está no registro ou constatação adequado, 'através da comparação', do que pertence a todos ou a muitos sob diversos modos de existência" (CHASIN, 2009, p. 124). Com o que, é o essencial a destacar no momento, “trata-se, pois, de algo geral extraído das formações concretas, posto à luz pela força de abstração, mas não produzido por um volteio autônomo da mesma, pois seu mérito é operar subsumida à comparação dos objetos que investiga" (CHASIN, 2009, p. 124). Com efeito, ao tempo que, nas passagens marxianas das quais Chasin depreende a noção de abstração razoável, na "Introdução de 1857”, refere-se à investigação científica, é importante perceber sua validade para o próprio pensamento humano. Ao melhor, é do método científico, por assim dizer, pois é o modo de operar da força de abstração: "o método científico não é mais do que a maneira de proceder do pensamento" (CHASIN, 2009, p. 128), que, como abordávamos, explicita-se na atuação concreta dos homens.

Com efeito, a identificação da prática enquanto solo originário do pensamento permite, em segundo lugar, remeter ao seu caráter histórico e social. Isto é, "a consciência é, naturalmente, antes de tudo a mera consciência do meio sensível mais imediato e consciência do vínculo limitado com outras pessoas e coisas exteriores ao indivíduo que 
se torna consciente" (MARX; ENGELS, 2007, p. 35). A reflexão de Marx e Engels é, nesse momento, obviamente filogenética, mas, como em diversos outros casos, aquilo que é válido para o gênero, o é igualmente para o indivíduo. Podemos dizer que também para cada indivíduo, em sua vida cotidiana imediata, tal é o perfil inicial de sua consciência (sempre social): do meio sensível e do vínculo limitado com outras pessoas e coisas. As implicações para a reflexão sobre uma "consciência geográfica" são evidentes, porém, no momento, nos interessa atentar para a percepção marxiana de uma das "formas pelas quais a consciência conhece o mundo: a intuição (de que deriva um 'saber imediato')" (NETTO, 1994, p. 29). E, com efeito, Marx e Engels acentuam, ainda, que a consciência “é, ao mesmo tempo, consciência da natureza" que está a ser apropriada por meio do trabalho e, "inicialmente, se apresenta aos homens como um poder totalmente estranho, onipotente e inabalável, com o qual os homens se relacionam de um modo puramente animal e diante do qual se deixam impressionar como o gado; é, desse modo, uma consciência puramente animal da natureza (religião natural)" (MARX; ENGELS, 2007, p. 35).

Em suma, a consciência, o pensamento, a subjetividade emergem (histórica e socialmente, como alertava Lefebvre) como a apropriação ideal do mundo no bojo de sua apropriação objetiva. Na medida em que teleológica, a ação humana "pressupõe certo grau de reflexo correto da realidade objetiva na consciência do homem" (LUKÁCS apud GASPAR, s/d., p. 5). Para além de repetir e reafirmar a fundamentação ontoprática do conhecimento, os presentes desdobramentos nos permitem apontar para a origem da própria ciência, bem como identificar suas características definidoras, enquanto uma das formas da apropriação ideal do mundo. Nesse sentido, a noção de ciência passa a referir mais do que tão somente padrões de reflexão estabelecidos na emergência da sociabilidade capitalista, mas, sim, a uma forma específica de reflexo da realidade na consciência humana demarcada, ainda que num processo histórico longo e contraditório, por sua orientação ontológica, isto é, pela

\footnotetext{
orientação do pensamento para a apreensão do 'ser precisamente assim' das coisas (adequatio intellectus ad rem) - como desantropomorfização do reflexo, que, de modo literal, significa a subtração das características humanas postas pelo sujeito cognoscente (geralmente de modo inconsciente) nos entes (como, de modo exemplar, são os casos do finalismo aristotélico e medieval) (GASPAR, s/d, p. 5).
} 
O eixo essencial do reflexo científico cabe, assim, ao processo de desantropomorfização ${ }^{159}$, como define Lukács (2010, p. 61), isto é, como o "processo de passar para o plano de fundo", de desconsiderar "tudo o que aparece inseparavelmente ligado à relação imediata do respectivo objeto de conhecimento com o ser humano real que percebe", numa palavra, a "abstração do ser humano em relação à sua própria imediatidade" e, por conseguinte, daquilo que o sujeito que conhece imputa na realidade. Processo que "deixa, desse modo, seu lugar para os momentos realmente existentes em si, e capacita o ser humano a perceber o mundo como ele é em si, independente" (LUKÁCS, 2010, p. 61) do indivíduo concreto e determinado que busca o conhecimento $^{160}$.

Nesse sentido, “a desantropomorfização é e continuará sendo um dos mais importantes e indispensáveis meios para o conhecimento do ser como ele realmente é, como ele é em si, como foi e como permanece sendo" (LUKÁCS, 2010, p. 61). Esta orientação materialista, ou ontológica, está presente no próprio pensamento cotidiano (a intuição espontânea), ainda que de maneira, por suposto, espontânea, no sentido apontado por Lefebvre (1991) - de que sempre nos sabemos rodeados por coisas, com as quais interagimos. E apenas de maneira complexa evolui para a constituição de um "pensamento materialista propriamente científico". Exercerá importante papel para tanto, como é sabido, o desenvolvimento do capitalismo: "só a produção capitalista foi profundamente inclinada e capacitada econômica e socialmente a constituir para suas finalidades, de forma consciente, uma ciência particular no sentido atual” (LUKÁCS, 2010, p. 62).

Em outras palavras,

o modo de produção capitalista, com sua intrínseca necessidade de desenvolvimento das forças produtivas - e a consequente destruição dos limites sagrados restritivos ao conhecimento -, constitui-se, em contraposição aos antigos modos de produção escravista e feudal, num inequívoco impulsionador permanente dessa orientação intelectual desantromorfizadora e, portanto, da ciência (GASPAR, s/d, p. 8).

\footnotetext{
${ }^{159}$ Lukács discute extensivamente as questões relativas ao processo de desantropomorfização, inclusive seu desenvolvimento histórico, na sua Estética, em especial no capítulo 2 - "La desantropomorfización del reflejo en la ciencia", do livro 1.

${ }^{160}$ No mesmo sentido afirma Karel Kosic (1976, p. 22), tendo em vista a dificuldade de análise de acontecimentos contemporâneos e a relativa facilidade da referida aos acontecimentos passados, "porque a própria realidade já se incumbiu de fazer uma certa eliminação e 'crítica'. A ciência deve 'reproduzir, artificialmente e experimentalmente este caminho natural da história. /.../ a ciência alcança um distanciamento conveniente e motivado em cuja perspectiva as coisas e os acontecimentos se mostram de maneira adequada e isenta de falsificações".
} 
Este impulso, embora indubitável, não é incontroverso ou despido de contradições, na medida em que se realiza em uma sociabilidade profundamente clivada e contraditória. Com efeito, a burguesia se relaciona de modo sempre complexo em relação a todos os efeitos advindos de sua postura, derivada de sua práxis econômica, que tende a impulsionar o reflexo desantropomofizador da realidade, como meio e caminho do desenvolvimento das forças produtivas, como Marx e Engels já caracterizavam no Manifesto do partido comunista. Por exemplo, embora o desenvolvimento científico, em especial o das ciências naturais, constituísse vigorosamente as bases para uma concepção de mundo unitária e igualmente científica, isto é, para uma ontologia científico-filosófica, tanto as demandas de conciliação com as forças reacionárias, quando da emergência social da burguesia, como as postas pela própria conversão da burguesia em classe dominante, conforme vimos, por exemplo, com David Harvey, terminam por obstaculizar tal encaminhamento.

Assim, a ontologia marxiana não apenas enseja a afirmação radical da possibilidade do saber, como representa, em essência, a efetiva possibilidade de constituição de uma ontologia efetivamente fundada na ciência e na apreensão dos seres. Vale um breve excurso sobre a questão ontologia para melhor situá-la e problematizar suas relações com a ciência.

\subsubsection{BREVES NOTAS SOBRE AS RELAÇÕES ENTRE ONTOLOGIA E CIÊNCIA}

O radical direcionamento imanente em relação aos objetos - "reconhecidos como a malha sólida de suas próprias lógicas" (CHASIN, 2009, p. 90-1) -, a posição ontológica marxiana, permite, com efeito, remontar às origens mesmo da filosofia, na medida em que "Tales e outros integrantes da primeira escola filosófica - Escola de Mileto -, como Anaxímenes e Anaximandro, foram os pioneiros no estabelecimento de princípios explicativos para a natureza a partir de elementos dela própria, isto é, livres dos mitos ou compromissos religiosos" (CARVALHO, 1990, p. 34). Nesse sentido, podemos dizer que a filosofia nasce, em grande medida por conta mesmo dos limites da religião no mundo 
grego clássico ${ }^{161}$, mas também dada a complexificação ${ }^{162}$ da vida social no mundo grego, enquanto ontologia ${ }^{163}$, enquanto busca de apreensão do ser-precisamente-assim da realidade:

A nova filosofia dos pré-socráticos, em sua rápida gênese, descobriu uma após a outra e uma ao lado da outra as categorias mais importantes [da ontologia]. $\mathrm{O}$ fato de que só pudessem se tratar de primeiras aproximações, em geral expressas de modo semimítico, dos fatos autênticos não diminui em nada a grandiosidade desse primeiro intento (LUKÁCS, 2012, p. 32-3).

A reflexão sobre o ser mesmo da realidade receberá, posteriormente, uma sistematização mais aprofundada. Ou seja, é "com Aristóteles (384-322 a. C.), o principal historiador e organizador do saber desenvolvido pelos filósofos, que este 'mundo da natureza' descortinado pelos gregos ganhará sua grande sistematização" (CARVALHO, 1990, p. 35). É também com Aristóteles que temos uma primeira especificação nominativa do setor da reflexão sobre o ser fundante da realidade: trata-se da filosofia primeira, mais adiante designada também como metafísica ${ }^{164}$. Não nos cabe, aqui, nem minimamente, tracejar o sentido dessa reflexão - dados nossos próprios limites e os de uma dissertação de mestrado. Buscamos, tão somente, apontar para os elementos principais que permitem a compreensão da radicalidade da nova posição marxiana. Nesse sentido, basta perceber dois elementos: em primeiro lugar, a filosofia primeira aristotélica é reconhecida como a reflexão sobre a base fundante da realidade e, por conseguinte, das demais ciências (particulares) que buscam sua compreensão. Põe-se, assim, como um "sistema abstrato de categorias - de caráter lógico, transcendental - no qual se buscam os fundamentos, as origens, o sentido ou a própria razão da existência dos seres reais, objetivos, por meio do qual estes não apenas são ontologicamente derivados/dependentes como, ainda, cognoscitivamente explicados" (GASPAR, s/d, p. 2).

\footnotetext{
161 Como também reconhece Lukács: "A Antiguidade grega, em que não havia poder sacerdotal nem teologia dogmático-obrigatória, pôde, como consequência, tornar-se o reino clássico da gênese da ontologia. /.../. Ela pôde dirigir-se de maneira tão monumentalmente retilínea para os objetos mais essenciais dada a ausência de qualquer conflito com a teologia” (LUKÁCS, 2012, p. 32 e 33 ).

162 "É que a racionalidade mítica passa a ser insuficiente para guiar a produção e reprodução da vida no contexto grego daquele momento", lembrando-se que, mais do que a reprodução fisiológica, trata-se da "reprodução da vida humana e, como tal, está embutido nisto a reprodução do espírito" (CHASIN, s/d, p. 14). Mais concretamente, e de fundamental importância à nossa reflexão, vale também lembrar que a filosofia "nasce da cidade, com a divisão do trabalho e suas modalidades múltiplas" e, mais, "a obra da cidade continua e se concentra na obra dos filósofos, que recolhe as opiniões e os conselhos, as obras diversas, que reflete sobre elas numa simultaneidade, que reúne diante de si as diferenças numa totalidade" (LEFEBVRE, 2001, p. 30.

163 Embora esta denominação surja apenas no século XVII.

${ }^{164}$ Designação também posteriormente estabelecida.
} 
Em segundo lugar, é necessário apontar para seus limites, já acima expressos, na medida em que se realiza no interior de uma situação histórico-social caracterizada pelo limitado desenvolvimento das forças produtivas ${ }^{165} \mathrm{e}$, portanto, na "impossibilidade de conceber a historicidade e a contraditoriedade como categorias fundamentais do ser - que estrangulam a mais precisa e universal, por isso mesmo válida hoje e para sempre, das formulações atinentes à natureza e ao propósito da ontologia" (CHASIN apud VAISMAN, 2001, p. VII). Dada a busca por categorias ahistóricas, imutáveis e perenes, a ontologia aristotélica reproduz, ainda que o critique, o "dualismo ontológico" inaugurado por Platão. Mesmo no caso de Aristóteles, "apesar do caráter amplamente terrenal de sua ética, de sua estética, de sua doutrina de Estado e sociedade e de partes extensas de sua filosofia da natureza, sua concepção do cosmo, tendo o motor imóvel como questão-chave, ainda se movimenta na linha de uma ontologia de dois mundos" (LUKÁCS, 2012, p. 34).

Em outros termos, segundo Lukács, o "generoso objetivismo", o "monismo cósmico" da Filosofia da Natureza "manteve-se predominante na cultura grega até Sócrates", até "a crise da pólis - e, com ela, a centralidade emprestada aos problemas morais" (LUKÁCS, 2012, p. 33) ${ }^{166}$. E aqui temos a novidade da posição de Platão e seu idealismo objetivo: o desenvolvimento de uma ontologia como fundamento para resolução dos dilemas morais (do “que fazer?") de uma sociedade comunitária em dissolução (e, portanto, de dissolução de seus parâmetros éticos), “cuja concepção de realidade, cuja imagem de mundo, pretendia oferecer uma garantia de que os postulados morais aparentemente imprescindíveis para a salvação da pólis pudessem ser fixados como possíveis e necessários" (LUKÁCS, 2012, p. 34). Introduzindo na filosofia ocidental a dimensão presente em praticamente todas as religiões: a existência real de um mundo das essências e o entendimento do mundo "real" enquanto sua depreciação ou degeneração. De fato, na religião "o elemento comum é que o acontecimento essencial do mundo não pareça um acontecimento fundado em si mesmo, mas aparente ser produto de uma (transcendente) atividade ponente" (LUKÁCS, 2010, p. 47), e é exatamente esse

\footnotetext{
${ }^{165}$ Lembra, por exemplo, Richard Sennet (2008, p. 35): "no mundo antigo, as técnicas de agricultura eram tão rudimentares que, segundo o historiador Lynn White 'mesmo nas regiões mais prósperas, eram necessárias dez pessoas vivendo no cultivo para que uma pudesse viver longe da terra"'. Especificamente acerca do pensamento de Aristóteles e sua vinculação com este contexto social, cf. Milney Chasin (2007). Por fim, desdobraremos ainda algumas características dessas limitações do contexto grego, e de todas as formações sociais pré-capitalistas, na visão de Marx, no próximo capítulo.

${ }^{166}$ Sobre a crise da pólis grega e suas implicações para a reflexão filosófica, cf. HELLER (1983).
} 
o caráter da determinação platônica da existência do mundo das Ideias, enquanto mundo das essências, e o mundo fenomênico das sombras. Tal dimensão, por suposto, é radicalizada na filosofia medieval (especialmente fundamentada em Aristóteles). O que, no entanto, não impugna seu caráter ontológico, na medida em que, mesmo em Platão, "este mundo das ideias é algo objetivo, isto é, algo que não está no interior da subjetividade, pertence a uma exterioridade na subjetividade" (CHASIN, s/d, p. 3). Assim, em toda a Idade Média, "não obstante todas as transformações fundamentais da imagem de mundo originária da cristandade, a estrutura bimundana sempre é mantida" em que, dado o caráter teleológico do "mundo dos seres humanos", "o cosmo é, portanto, fundamento ontológico e objeto visível do poder de Deus" (LUKÁCS, 2012, p. 36-7).

Ivo Tonet esclarece a semelhança explícita nos padrões antigos e medievais na reflexão sobre as coisas e o mundo, após indicar que ambas se estabelecem em momentos, ainda que distintos, de crise e reorganização das sociabilidades ${ }^{167}$. Vale a citação completa:

Como o objetivo principal não era a produção de um conhecimento voltado para a transformação da natureza, mas para a organização e a direção da polis e/ou da vida para a transcendência, tratava-se de elaborar um tipo de conhecimento que pudesse servir a esses propósitos. Fundamental, para isso, seria o conhecimento da ordem universal e dos valores mais sólidos, universais e imutáveis, tais como a verdade, o bem, a justiça, o belo etc. Só eles permitiriam encontrar estruturas mais firmes que garantissem maior estabilidade à organização da polis e da sociedade. Por outro lado, quem elaborava esse tipo de conhecimento eram aqueles que se ocupavam das coisas do espírito. Não é difícil entender como isso proporcionava um fundamento aparentemente sólido à autonomia das ideias (TONET, 2013, p. 25).

Interessante perceber, a fim de encaminhar nossa reflexão, que é exatamente contra esta imagem de mundo que Marx se insurge desde o início da formulação de seu pensamento próprio, com a centralidade por ele mesmo atribuída à crítica da religião, a partir das contribuições revolucionárias de Feuerbach. Mas trata-se, em seu caso, da refutação da ontologia religiosa de uma forma substancialmente distinta da que dar-se-á ao longo do século XVI e da instituição da filosofia e ciência modernas. Isto é, no âmbito das profundas transformações materiais na vida cotidiana dos homens ${ }^{168} \mathrm{e}$, na esfera da

${ }^{167}$ Platão e Aristóteles no declínio final das cidades-estado gregas, sucumbindo ao domínio macedônico. Agostinho na derrocada do Império Romano e Aquino "em um momento em que profundas transformações no interior do mundo feudal começam a sinalizar a emergência de uma nova forma de sociabilidade" (TONET, 2013, p. 25)

168 Trata-se da, associada ao crescimento e expansão do comércio, fundamental "inflexão do agrário para o urbano", de acordo com Lefebvre (1999, p. 23 e 24): "O peso da cidade no conjunto social torna-se tal que o próprio conjunto desequilibra-se. /.../. Desde esse momento, a sociedade não coincide mais com o campo. /.../. O racionalismo que culmina com Descartes acompanha a inversão que substitui a primazia camponesa pela prioridade urbana". 
ciência, "com a substituição da física ptolomaica pela física de Copérnico, no final da Idade Média, a metafísica aristotélica veio a ruir, o que colocou a necessidade de uma nova metafísica, de base copernicana. Essa foi a tarefa que se impôs Descartes" (SAVIANI; DUARTE, 2012, p. 17). Esta "nova metafísica", no entanto, é de caráter específico na medida em que se estabelece na forma de uma "metafísica do sujeito", isto é, desloca o núcleo da reflexão filosófica para o âmbito das condições e possibilidades do saber, e não mais do ser. Em suma, nas palavras dos filósofos brasileiros: "A metafísica dos tempos antigos e medievais, isto é, a metafísica aristotélica, era uma metafísica do objeto (ou objetivista). Em contrapartida, a metafísica da modernidade era uma metafísica do sujeito (ou subjetivista)" (SAVIANI; DUARTE, 2012, p. 18). Do mesmo modo Chasin entende a verdadeira revolução que, mais do que a filosofia kantiana, representa a metafísica instituída por Descartes:

\begin{abstract}
a partir de Descartes gera-se uma ontologia da subjetividade. Podemos dizer que até Descartes nós temos uma ontologia da objetividade ou da realidade cósmica ou cosmológica e a partir dele esta ontologia é substituída por uma ontologia da subjetividade. Não mais agora o mundo externo, mas o mundo interno é que passa a ser o grande objeto de reflexão (CHASIN, s/d, p. 23).
\end{abstract}

Esta ênfase nas condições e possibilidades do conhecimento, em uma palavra, na gnosiologia, acentuar-se-á, atingindo uma espécie de ápice com Berkeley e Kant, “a despeito de todas as diferenças entre ambos. No essencial, o elemento comum das aspirações de ambos consiste em demonstrar gnosiologicamente que não é possível atribuir significado ontológico aos nossos conhecimentos do mundo material" (LUKÁCS, 2012, p. 39). Em outros termos, se em Descartes ainda temos o reconhecimento de que o objeto configura uma res extensa, uma substância material a ser conhecida pelo sujeito demarcando que a tarefa, em última instância, de determinação (ou definição) já recaia sobre o sujeito - nos dois pensadores do século XVIII tem-se uma progressiva eliminação da substância material, da possibilidade de apreensão da coisa em-si, de modo que "a história da filosofia moderna pode ser lida como a história da erosão da noção de substância, isto é, como um processo que começou admitindo a ideia de substância, mas progressivamente a eliminou" (SAVIANI; DUARTE, 2012, p. 18). Nesse sentido, não apenas a ontologia religiosa, mas toda a possibilidade de ontologia, isto é, de apreensão do ser-precisamente-assim, é impugnada na conformação da filosofia moderna.

É válido perceber, por outro lado, que tal impugnação efetiva-se no bojo do desenvolvimento das ciências modernas (e, em realidade, tem neste um de seus principais determinantes), de evidente direcionamento imanente. Daí que Lukács identifica a origem 
do relativismo moderno no contexto da emergência da burguesia, que demandava os conhecimentos das ciências naturais, e o estabelecimento de um compromisso com a Igreja Católica, ainda detentora de poder político e ideológico, no sentido de afirmar a “teoria da dupla verdade". Afirma o filósofo húngaro que a preponderância, nos últimos séculos do pensamento filosófico, da teoria do conhecimento

\begin{abstract}
se tornou tão forte que a opinião pública competente esqueceu totalmente que a missão social da teoria do conhecimento, que culminou em Kant, consistia, quanto a sua finalidade principal, em fundamentar e assegurar o direito à hegemonia científica das ciências naturais desenvolvidas desde o Renascimento, mas de tal maneira que permanecesse preservado para a ontologia religiosa, na medida em que isso fosse socialmente desejável, o seu espaço ideológico historicamente conquistado. Nesse sentido histórico amplo, podemos considerar o cardeal Bellarmino como o pai da moderna teoria do conhecimento (LUKÁCS, 2010, p. 33).
\end{abstract}

E mais, em outro momento, Lukács (2012, p. 38-9) pontua que, na aurora da modernidade, tal teoria é gestada de forma específica, distinta da existente em formações sociais anteriores, dada a "percepção instintivamente correta da nova situação por parte da Igreja: para a nova classe dominante em ascensão, para a burguesia, o desenvolvimento irrestrito das ciências, sobretudo das ciências naturais, era uma questão vital" já que estes conhecimentos "deveriam ser utilizados para melhor dominar as forças da natureza". Nesse sentido,

Enquanto em fases precedentes a teoria da dupla verdade fora concebida para proteger o desenvolvimento da ciência à sobra da aparentemente inabalável ontologia religiosa, agora a Igreja, a ideologia religiosa oficial, recorria à teoria da dupla verdade para salvar ao menos temporariamente aquilo de sua ontologia de que não gostaria de renunciar (LUKÁCS, 2012, p. 38).

Em uma palavra, tratava-se de conter o "irresistível avanço da ontologia fundada sobre as ciências da natureza" derivado da "repercussão que a ruptura com a posição cósmica e ontológica especial da Terra teve no plano das concepções de mundo" (LUKÁCS, 2012, p. 39).

Em certa medida, é exatamente nesse sentido que, em Marx, a ontologia religiosa é refutada e reconhecida como a limitação dos homens no quadro histórico-concreto de ser social, como o "suspiro da criatura oprimida", isto é, sintetizando com Lukács o que já vimos e desdobrando, basta lembrar que a religião constitui

uma imagem de mundo na qual os desejos que transcendem a existência cotidiana dos seres humanos, não atendidos na vida cotidiana, adquirem uma perspectiva de realização num além apresentado com pretensão ontológica. A ontologia religiosa surge, portanto, por uma via oposta à da ontologia científico-filosófica: esta investiga a realidade objetiva para descobrir o real espaço para a práxis real (do trabalho à ética); aquela se move desde as necessidades de um comportamento diante da vida, das tentativas feitas pelos 
seres humanos singulares do cotidiano de conferir sentido à própria vida, e constrói uma imagem de mundo que, se efetiva, poderia constituir uma garantia para a realização daqueles que se manifestam na necessidade religiosa (LUKÁCS, 2012, p. 32).

Ou seja, é significativo que o pensamento mesmo de Marx se inicie com a ruptura com a ontologia religiosa, a partir da compreensão de sua gênese e necessidade. Representando, dessa forma, a possibilidade de efetivo avanço e desdobramento de uma ontologia fundada nos avanços científicos ${ }^{169}$. Assim, podemos reter o elemento fundamental, como sustentado copiosamente ao longo do capítulo: no pensamento marxiano não temos nem uma metafísica de talhe tradicional (in limine, religiosa, das essências) nem a, em última instância, negação da ontologia a partir e pelo centramento na subjetividade cognoscente. Em outros termos,

a nova ontologia - que, em oposição à antiga, não constitui uma metafísica e, à hedeggeriana, nem hipertrofia da subjetividade (em razão da qual o ser é o que é por causa da mediação/predicação do próprio homem) - somente pode consistir no resultado, bastante tardio, de um amplo desenvolvimento do pensamento filosófico-científico e, por conseguinte, de uma profunda crítica às ontologias metafísico-religiosas e às pseudomaterialistas e da apropriação de um conjunto extensivo e intensivo de conhecimentos parciais das ciências particulares (GASPAR, s/d, p. 2-3).

O que temos, assim, em Marx é a afirmação radical da possibilidade do saber, da ontologia científico-filosófica que investiga a realidade objetiva, dela extraindo os elementos fundamentais e necessários à confirmação prática do ser social. Nesse sentido, em relação à gnosiologia tradicional, aponta-se para o recentramento da questão: a prioridade da objetividade e de sua reprodução pela subjetividade, condição de sua própria manifestação. E tal posição, enfim, permite rever as relações entre filosofia e ciência, isto é, a partir da posição marxiana podemos

\footnotetext{
refletir filosoficamente sobre como a ontologia pode auxiliar tanto na fecundação da ciência quanto na correção de suas atividades teórico-práticas de desvendamento dos entes e relações específicas - seja em seus aspectos singulares ou em suas conexões com o todo -, especialmente sua contribuição para a dissolução de equívocos acumulados ao longo do tempo e o aprofundamento da corrente filosófico-científica que, na ordem do capital, possui uma função de desmistificação e orientação da práxis revolucionária, o marxismo (GASPAR, s/d, p. 13) ${ }^{170}$.
}

\footnotetext{
${ }^{169}$ Além da tradição marxista fundada em Lukács, John Bellamy Foster (2005, p. 37) explicita, a meu ver, consideração análoga nesse aspecto. "Os insights tantas vezes brilhantes de Marx não foram meras centelhas de gênio. Os insights dele nesta área [ecologia] são antes derivados de um compromisso sistemático com a revolução científica do século XVII e o meio ambiente do século XIX mediante um profundo entendimento filosófico da concepção materialista da natureza".

${ }^{170}$ Vale remeter para toda a última parte do artigo de Gaspar, a investigar aspectos variados das relações entre ontologia e ciência.
} 
A fim de encaminhar nosso trabalho, sem nos imiscuir mais ainda em questão sabidamente complexa, acredito, aqui, poder seguir os indicativos de Armando Corrêa da Silva (1986, p. 27), quando reconhecia que "a Filosofia é o nível do conhecimento mais geral que se pode conceber. É nela, portanto, que as categorias, como determinações da existência, possuem seu grau mais amplo de generalidade”. Já as categorias científicas "são mais concretas que as categorias da filosofia", o que "se deve ao fato de reproduzirem a existência em nível menor de abstração" (SILVA, 1986, p. 27). Tratam, portanto, em especial, de aspectos particulares da realidade.

Com efeito, Karel Kosic (1976, p. 116-7) já alertava que

o homem chega por meio de ciências especiais ao conhecimento de setores parciais da realidade humano-social e à comprovação de sua verdade. Para o conhecimento da realidade humana no seu conjunto e para descobrir a verdade da realidade na sua autenticidade, o homem dispõe de dois 'meios': a filosofia e a arte.

As próximas seções objetivam melhor caracterizar este ponto, tomando como referência os elementos relativos à ciência geográfica, enquanto ciência particular, especial, referida ao ser social e das vias de interlocução com um saber de conjunto, como é a filosofia.

\subsection{TOTALIDADE, COMPLEXOS E DETERMINAÇÕES}

A discussão anterior é fundamento para problematização de uma questão que se põe logo nos primeiros movimentos da ciência geográfica de apropriação do marxismo. A questão da ciência particular e da dimensão espacial, em outras palavras, de que modo se justifica uma ciência particular na órbita do marxismo ${ }^{171}$, se, em geral, no que se refere ao contexto sociopolítico da constituição das "ciências humanas", estas associam-se à

${ }^{171}$ Muito se valeu, por exemplo, da afirmação marxiana de que apenas conhecia a "ciência da história" para afirmar-se a inviabilidade da proposta de uma ciência geográfica. Ao contrário, com efeito, tal advertência nos parece mais apontar para o caráter necessariamente histórico do ser social, ou seja, "que o universo da história é, a meu ver, muito amplo que o da geografia, e que, nesse sentido, a própria geografia é vista como um produto da história. Seja a geografia material objetivada no espaço terrestre, seja o discurso geográfico acerca de tais realidades, ambos constituem elementos do fluir histórico, sendo por ele explicáveis. Logo incluem-se na história, não podendo reportar-se a ela como um outro. /.../. Aqui reafirma-se a historicidade como caminho de entendimento dos objetos e processos sociais, entre eles os referentes à geografia" (MORAES, 2005, p. 23). 
operacionalização de um pensamento conservador em oposição aos movimentos dos trabalhadores e, por conseguinte, ao próprio marxismo. De fato, a apropriação direta da obra de Marx, no âmbito da Geografia, nos obriga a repor a ressalva já apresentada neste trabalho - consideramos que não é possível afirmar a existência de uma "teoria geográfica marxista", o que talvez tenha motivado Lacoste - numa reflexão, como vimos, pautada em critérios epistemológicos ${ }^{172}$ - a inferir uma negligência em relação ao espaço ${ }^{173}$. Parece-nos que a obra de Marx dificilmente se presta a exercícios de reflexão a partir dos fundamentos filosóficos assentados na gnosiologia das ciências sociais contemporâneas, em suma, sua obra não se encaixa em nossas divisões disciplinares e a busca por problematizar um objeto autonomamente termina por violentar a essência mesma de seu pensamento - a posição ontológica identificada e que o caracteriza desde os momentos germinais de 1843-44. Tal característica, no entanto, não me parece impedir a delimitação de campos de reflexão, diríamos, seguindo Moraes (2000), campos disciplinares que atentam para processos ou dimensões específicas da realidade.

Acompanhamos, aqui, por exemplo, também Atilío Bóron (2003, p. 96) quando afirma, a respeito especificamente da questão da teoria política que "não há e não pode haver uma teoria 'política' marxista. Por quê? Porque para o marxismo nenhum aspecto da realidade social pode ser entendido à margem - ou com independência - da totalidade na qual aquele se constituiu". Tal consideração, porém, não implica invalidar a possibilidade de uma teoria marxista da política (poderíamos dizer da geografia? Buscaremos, mais adiante problematizar esta possibilidade), isto é, não impede a existência de "recortes conceituais que permitem delimitar um campo de reflexão e análise que pode, desse modo, ser explorado de forma sistemática e rigorosa" (BORON, 2003, p. 97) e isto porque, seguindo Lukács, o mesmo Boron afirma que

o que distingue o marxismo de outras correntes teóricas nas ciências sociais não é a primazia dos fatores econômicos - um autêntico barbarismo, segundo Marx e Engels -, mas o ponto de vista da totalidade, isto é, a capacidade da teoria de reproduzir na abstração do pensamento o conjunto complexo e sempre mutante de determinações que produzem a vida social (BORON, 2003, p. 99).

Vale ressaltar o reconhecimento desta real especificidade do pensamento marxista, de acordo com Lukács (História e consciência de classe), e conforme

${ }^{172}$ Cujo aprofundamento na discussão não deixa de demarcar, aliás, numa disciplina tão pouco afeita às discussões teóricas, um considerável avanço.

173 “A fraqueza do papel da análise marxista em geografia, não é menos surpreendente. É preciso, de início, constatar o silêncio, o 'branco' em relação aos problemas espaciais, que caracteriza a obra de Marx" (LACOSTE, 2007, p. 140). Dimensão igualmente presente em E. Soja (1993). 
explicitamos na última seção do capítulo anterior - a referência à totalidade. E não, como vemos em algumas posições críticas ao marxismo, e também na crítica à crítica da geografia, algum tipo de determinação econômica unilateral ou unilinear. Ou de qualquer forma de determinismo - inclusive geográfica ou ambiental.

Reflexões análogas encontramos em outros estudiosos da obra de Marx. Ainda no que se refere especificamente à questão da política, ressaltando seu caráter ontológico, afirma Lívia Cotrim (2007, p. 36) que a crítica da política, analisada no capítulo anterior, "não deu nem poderia dar lugar a uma nova teoria política, sob cuja ótica fossem observadas as situações concretas, ou com cujas pinças fossem estas agarradas". Em outros termos, embora os fundamentos elaborados por Marx, no momento de formação de seu pensamento próprio, reapareçam quando da análise de momentos concretos da realidade social, não temos aqui “a 'aplicação' de um referencial teórico a um caso concreto, mas uma espécie de redescoberta das mesmas determinações a partir da análise de uma ocorrência histórica" (CHASIN, 2009, p. 154). Enfim, "seja porque o objetivo é apreender a lógica da coisa, isto é, o objeto tal como existe por si mesmo, seja porque aquela crítica envolve a percepção dos limites da razão política" (COTRIM, 2007, p. 36) não se produz uma nova teoria que sirva de referencial para análise e aplicação. Ou seja, dada a nova concepção alcançada, calcada na posição ontológica que busca a compreensão da lógica específica do objeto específico - ou a lógica da coisa - o que se tem nos textos de Marx é o profundo exame da condição concreta e de suas determinações:

\begin{abstract}
ao invés de uma teoria política, divisamos um exame que busca descortinar e reproduzir mentalmente as determinações, conexões, processos etc. constitutivos do existente. Apanhadas as categorias e suas inter-relações, trabalho possibilitado pela mencionada maturação e tensionamento do próprio objeto, resultará igualmente iluminado o nível e a forma da generalização de cada uma delas, isto é, será possível identificar sua presença, sob forma determinada, em outros lugares e épocas, ou, ao contrário, em uma única região ou período. Em outras palavras, os diferentes níveis de generalização presentes nas obras em foco são reproduções intelectuais de categorias reais, não criações apriorísticas do autor (COTRIM, 2007, p. 36).
\end{abstract}

A advertência é fundamental: não se trata de buscar constituir um referencial teórico que franqueie sua aplicação aos casos e objetos concretos de análise. Bóron nos deu um bom efeito e exemplo dessa recusa: igualmente não se trata de afirmar a primazia de determinados "fatores" e, assim, buscar seu entendimento e o emprego da teoria em situações particulares, mas, sim, reproduzir idealmente o conjunto complexo e sempre mutante de determinações que produzem a vida social, isto é, a totalidade social. 
De fato, o acompanhamento da constituição do pensamento marxiano permitiu evidenciar a emersão dessa questão - a primazia da totalidade e a busca da compreensão dos complexos que configuram a vida social - e pode ser destacada ao constatarmos a própria vinculação das críticas ontológicas entre si, conforme explicitado no capítulo anterior, e a centralidade que passa a adquirir a noção de atividade sensível. No caso de Marx, o ponto de partida é a crítica da religião que, na inversão realizada, passa a ser entendida como a espiritualidade alienada. Daí passamos à política e economia. Ou seja, enquanto a filosofia especulativa pode ser reconhecida como uma faceta da alienação religiosa em geral, ambas (idealismo e religião) configuram dimensões subjetivas do processo de alienação, isto é, a projeção intelectual, no pensamento, da essência humana fora dos próprios homens que, por sua vez, radicam nas formas objetivas da alienação política e econômica, em suma, na separação real dos homens em relação às suas próprias forças - de gestão social, para a primeira, e do próprio trabalho, para a segunda.

Assim, embora a designação da realidade (em especial a realidade social) como um complexo de complexos apenas se efetive no bojo do intento lukácsiano de recuperação do caráter ontológico da obra marxiana, parece-me corresponder efetivamente à essência desta. É este o sentido principal, por exemplo, da afirmação de que

o fato é, portanto, o seguinte: indivíduos determinados, que são ativos na produção de determinada maneira, contraem entre si estas relações sociais e políticas determinadas. A observação empírica tem de provar, em cada caso particular, empiricamente e sem nenhum tipo de mistificação ou especulação, a conexão entre a estrutura social e política e a produção (MARX; ENGELS, 2007, p. 93).

As diversificadas interações entre esses complexos - nesse caso, a estrutura social e política e a produção - aparecem como elementos a serem apreendidos pela análise concreta, empírica, em cada caso particular. O que não impede, é claro, de afirmarem a prioridade ontológica da produção material, isto é, de sua consideração enquanto um momento preponderante 174 já que: “A estrutura social e o Estado provêm constantemente do processo de vida de indivíduos determinados, /.../ tal como realmente são, quer dizer, tal como atual, como produzem materialmente e, portanto, tal como desenvolvem suas

\footnotetext{
174 Tomando como referência a constituição do conhecimento (daí a indicação às abstrações razoáveis), mas que podem, na medida em que se compreenda o pensamento como a reprodução ideal da lógica real, ser transpostas para a objetividade, temos que, "em termos bem sintético, o momento preponderante tem por identidade a condição de elo tônico no complexo articulado das abstrações razoáveis, ou seja, é o outro nome da categoria estruturante do todo concreto, e por isso também da totalidade ideal, uma abstração razoável que se destaca, sobredeterminando as demais com seu peso ordenador específico" (CHASIN, 2009, p. 135).
} 
atividades sob determinados limites, pressupostos e condições materiais, independentes de seu arbítrio" (MARX; ENGELS, 2007, p. 93). E a produção material, a atividade sensível, é o momento predominante, já o haviam afirmado na crítica a Feuerbach, na medida em que "se ela fosse interrompida mesmo por um ano apenas, Feuerbach não só encontraria uma enorme mudança no mundo natural, como também sentiria falta de todo o mundo dos homens e de seu próprio dom contemplativo, e até mesmo de sua própria existência” (MARX; ENGELS, 2007, p. 31).

Por outro lado, reconhecer o caráter ontologicamente prioritário da produção material não implica na afirmação de qualquer tipo de determinação unilateral. Ao contrário, parte do reconhecimento da existência desses distintos complexos e de suas relativas autonomias. Aliás, aqui podemos arrematar um interessante ponto de contestação a qualquer acusação de determinismo ou economicismo. Logo na sequência da constatação do enraizamento das estruturas social e política na produção material, Marx e Engels afirmam que, assim como produzem sua vida material, os homens produzem suas ideias, de maneira necessariamente associada àquela: "a produção de ideias, de representações, da consciência, está, em princípio, imediatamente entrelaçada com a atividade material e com o intercâmbio material dos homens, com a linguagem da vida real" (MARX; ENGELS, 2007, p. 93). A argumentação é complexa, mas vale perceber que os filósofos alemães rementem a produção espiritual ao comportamento material dos homens: "o representar, o pensar, o intercâmbio espiritual dos homens ainda aparecem, aqui, como emanação direta de seu comportamento material" (MARX; ENGELS, 2007, p. 93). Isto é, “os homens são os produtores de suas representações, de suas ideias e assim por diante, mas os homens reais, ativos, tal como são condicionados por um determinado desenvolvimento de suas forças produtivas e pelo intercâmbio que a ele corresponde, até chegar às suas formações mais desenvolvidas” (MARX; ENGELS, 2007, p. 94).

No tocante a este ponto, em especial a última citação, iniciemos por perceber a complexidade da noção de forças produtivas, "desde que não se considere a interação entre os grandes complexos estruturais da sociedade como portadora de uma lógica independente das existências individuais, as quais nessa estrutura não seriam mais do que mero suportes" (TEIXEIRA, 1999, p. 227), isto é, desde que se rompa com a exclusão entre sociedade e indivíduo e se considere o indivíduo social. E com efeito, Marx se refere, em todos os momentos, aos indivíduos agindo em condições determinadas 
enquanto os agentes últimos da própria história ${ }^{175}$. Nesse sentido, é apenas em condições determinadas que "as forças produtivas aparecem como plenamente independentes e separadas dos indivíduos, como um mundo próprio ao lado destes". Trata-se, como já vimos, das condições da alienação, isto é, "que tem sua razão de ser no fato de que os indivíduos, dos quais elas são as forças, existem dispersos e em oposições uns com os outros". No entanto, grife-se: "essas forças só são forças reais no intercâmbio e na conexão desses indivíduos" (MARX; ENGELS, 2007, p. 94). Em outras palavras, as forças produtivas, são as forças e capacidades dos indivíduos, como afirmam em outra paragem: "a relação das forças produtivas com a forma de intercâmbio é a relação da forma de intercâmbio com a atividade ou a atuação dos indivíduos" (MARX; ENGELS, 2007, p. 68).

A compreensão das forças produtivas como as capacidades de manifestação ativa dos próprios indivíduos, assim, é um primeiro elemento para superar qualquer possibilidade de concepção de cariz economicista. Além disso, vale reter outra peculiaridade da passagem anteriormente citada. O que Marx e Engels afirmam, em suma, é que os homens reais, produtores de suas representações, são condicionados por um determinado desenvolvimento de suas forças produtivas $\boldsymbol{e}$ pelo intercâmbio que a ele corresponde. Isto é, os indivíduos concretos são condicionados por suas próprias capacidades de ação $e$ (vale lembrar a amplitude da noção de formas de intercâmbio, nessas passagens da obra marxiana) pelas formas concretas da existência e interação social. Ou seja, conforme sugerido e problematizado pelo educador espanhol Mariano F. Enguita (1993, p. 88) no capítulo denominado "O homem faz o homem: homem, ambiente e práxis"), a assim chamada superestrutura político-ideológica compõe um âmbito de determinação da consciência dos homens. Isto é, "a determinação das superestruturas sociais pela base econômica é algo claramente diferente da determinação da consciência pelo ser social", o que implica reconhecer, então, que "o que realmente determina a consciência não é para Marx a natureza pura, nem tampouco o modo de produção por si só, mas o conjunto das formas da vida social ou, dito em termos negativos, tudo aquilo que não tem uma existência meramente pensada".

175 "Esse modo de considerar as coisas não é isento de pressupostos. Ele parte de pressupostos reais e não os abandona em nenhum instante. Seus pressupostos são os homens, não em quaisquer isolamento ou fixação fantásticos, mas em seu processo de desenvolvimento real, empiricamente observável, sob determinadas condições" (MARX; ENGELS, 2007, p. 94). 
Desse modo podemos compreender, mais especificamente, o alerta de Marx e Engels de que a relação entre os complexos deveria ser apreendida de maneira empírica, em cada caso particular. Assim, com efeito,

em toda obra marxiana, as delimitações de caráter mais geral apenas encontram seu lugar próprio em relação a um tema ou a uma questão específica de que se ocupa o pensamento no processo de análise. Ou seja, em Marx não é possível, a não ser em momentos bastante localizados e breves, achar uma discussão de talhe conceitual mais amplo ou universal (ALVES, 2013, p. 100).

Por exemplo, no que diz respeito à questão gnosiológica, como já abordamos acima, mas que continua como eixo central dessa discussão, "seja o estatuto das categorias, seja aquele da cognição, tais problemas somente são examinados a partir da marcha mesma da analítica de uma coisa dada - ente, processo ou relação - na construção da explicação das causalidades que a conformam como tal" (ALVES, 2013, p. 100). Isto é, o que, em determinadas correntes do marxismo, é visto como uma pretensa ausência da reflexão epistemológica - que, por vezes, objetiva-se completar a partir de formulações kantianas - configura, na realidade, a fórmula marxiana de resolver a questão: a busca da captura do ser-precisamente-assim da realidade, como o identifica um de seus mais destacados analistas, ao reconhecer a "afirmação filosófica de Marx" como

uma consideração ontológica-filosófica da realidade em-si, que não se põe acima dos fenômenos considerados, coagulando-os em abstrações, mas se coloca, ao contrário - crítica e autocriticamente -, no máximo nível de consciência, com o único objetivo de poder captar todo ente na plena concreticidade da forma de ser que lhe é própria, que é específica precisamente dele (LUKÁCS, 1979, p. 27).

Acreditamos ser essa apreensão que permite, por exemplo, a Quaini (1979, p. 51) afirmar que no marxismo existem "além de inúmeros temas de pesquisa, também uma teoria da geografia e dos limites das condições e fatores geográficos”. Parece-me viável afirmar, sem deturpar o espírito da obra de Marx que, assim como é na crítica às formas de sociabilidade e individuação capitalistas que Marx apreende as categorias fundamentais do ser social, é de maneira concreta e com vistas a uma sociabilidade específica que problematiza o conteúdo geográfico da sociabilidade do capital (e das anteriores na medida em aborda a gênese desta última). Ou seja, se não devemos buscar a constituição de um referencial teórico a ser aplicado em situações concretas específicas, na perspectiva ontológica, é possível identificar e delimitar os fundamentos essenciais da realidade - tal como o fizemos igualmente ao acompanhar a constituição do pensamento de Marx. 
Nesse sentido, torna-se possível investigar de que maneira, dialogando com a ótica marxiana, a geografia se explicita e evidencia como uma determinação da realidade objetiva, enquanto um complexo. Em suma, põe-se a necessidade de buscarmos descortinar no existente a presença de um complexo de determinações que podemos chamar de geográficas ou espaciais.

\subsubsection{O COMPLEXO GEOGRÁFICO}

Perfilhado este como um esforço inicial de aproximação e sistematização (no sentido delimitado de estabelecer pressupostos para a abordagem da problemática da individuação), na perspectiva do estatuto ontológico marxiano, acerca da dimensão geográfica da realidade, evidencie-se, de saída, uma dupla e diferenciada inspiração. De um lado, a noção lukacsiana do ser social como um complexo de complexos e, de outro, a proposição de Pierre Monbeig, limitadamente desdobrada no âmbito da tradição disciplinar, de um complexo geográfico. Quanto à primeira, de todo modo inserida no bojo do descortinamento do caráter ontológico do pensamento de Marx, comentamos já alguns aspectos no item precedente - e ainda outros desdobramentos serão realizados na sequência. Quanto à segunda, demarcada igualmente como um intento de diálogo com a tradição da ciência geográfica (portanto, de distintos fundamentos teórico-filosóficos), este é o momento adequado de problematização.

Em uma palavra, a noção de complexo geográfico parece-me extremamente frutífera no sentido de apontar para a reunião e articulação de categorias - isto é, da apreensão teórica de uma multiplicidade de seres, processos, e relações - que explicitam uma dimensão específica da realidade. Com efeito, a noção de complexo geográfico é uma proposta de Monbeig (1957, p. 9, grifo meu) no sentido de superar a de "fato geográfico" que "tal como é correntemente admitida é errônea, e deve ser corrigida", pois, em realidade, "a pesquisa geográfica trata dos complexos de fatos e são esses complexos que, por sua localização no globo, são verdadeiros 'fatos' geográficos”. Assim, além de indicar a multiplicidade que toca à análise geográfica, na medida em que conforma a realidade geográfica, Monbeig, na passagem acima, igualmente pontua sua determinação fundamental: a topologia. Como desdobra mais adiante: "cabe ao geógrafo explicar esta localização, procurar-lhe as consequências, examinando as relações, ações e interações 
que unem uns aos outros os elementos constitutivos do complexo geográfico" (MONBEIG, 1957, p. 9). E é ainda mais assertivo na conclusão: “complexo geográfico, sim, porque se localiza e porque implica em ações recíprocas e mutáveis do meio natural e do meio humano" (MONBEIG, 1957, p. 9).

Neste ponto, vale recordar a inserção de Monbeig na "escola francesa", ainda que de maneira particular ${ }^{176}$, a fim de evidenciar seu entendimento da categoria de meio. Com efeito, da concepção do mundo de La Blache (em profunda interação e recuperação dos fundadores da geografia moderna) se destaca, de saída, a apreensão da totalidade enquanto um fato primário da materialidade e existência dos seres, manifesta na unidade das forças e fenômenos terrestres e na consequente interdependência recíproca de todos os seres. Tanto na introdução dos Princípios de geografia humana ${ }^{177}$ quanto em seus artigos de "divulgação" e "defesa" da geografia - "As Características Próprias da Geografia”, "Os Gêneros de Vida na Geografia Humana” e mesmo "A geografia na escola primária”, por exemplo, - o geógrafo francês aborda explicitamente, de saída e de maneira íntima e associada, as noções da unidade terrestre e de meio. Em relação, por exemplo, aos esforços efetivados por Humboldt e Ritter, já imbuídos por uma visão geral do globo, "todos os progressos posteriormente obtidos, no conhecimento da Terra, foram atribuídos a melhor esclarecer esse princípio de unidade" (VIDAL DE LA BLACHE, 1982, p. 38), expressa tanto nas dinâmicas das massas líquidas e atmosféricas do globo como na própria constituição da sua parte sólida, determinada pelo conjunto dos fatos tectônicos. A ideia da unidade terrestre, assim, corresponde à "concepção da Terra como um todo, cujas partes estão coordenadas e no qual os fenômenos se encadeiam e

\footnotetext{
176 "Monbeig nasceu em 1908 e conclui seus estudos superiores, em história e geografia, no final dos anos 20. Como todo geógrafo formado no entre-guerras, ele deve sua concepção de geografia à chama escola clássica, formada após a morte de Paul Vidal de La Blache" (DANTAS, 2009, p. 2). Dantas (2009, p. 3) apresenta ainda a tese de que foi exatamente o contato de Monbeig com a realidade brasileira que lhe permite o desenvolvimento do instrumental heurístico, como vimos, limitado, fornecido por esta tradição, adiantando os limites e obstáculos que a mesma enfrentará no pós-guerra: "Estando no Brasil, Monbeig toma consciência dos desafios que se colocam à geografia mais cedo do que se permanecesse na Europa. /.../; percebe que o instrumento que constitui a análise dos gêneros de vida não dá conta do essencial num país de povoamento recente, onde a economia está em reconstrução permanente". Também Max. SORRE, "A noção de gênero de vida e seu valor atual" (Coleção grandes cientistas sociais), em outro diapasão, discute a validade e atualidade da noção de gênero de vida. VASCONCELOS; HADAD; MARTINS Júnior (2012, p. 43), discutem "como a experiência com o território brasileiro permitiu a Monbeig contribuir para novas formas de se pensar na ciência geográfica".

${ }^{177}$ Obra representativa, de acordo com Ruy Moreira, da matriz de pensamento de La Blache, no que se refere à estruturação de uma "geografia da civilização", seu ponto em comum em relação a Ratzel. Cf. Ruy Moreira, 2006, pp. 24-39.
} 
obedecem às leis gerais de que derivam os casos particulares" (VIDAL DE LA BLACHE, 1959, p. 30).

Dessa forma, a compreensão da unidade terrestre, determinada por leis gerais ${ }^{178}$, desemboca na percepção da existência de combinações locais entendidas, antes de tudo, como um fato ontológico, isto é, "antes de prosseguir, notemos que esta combinação é a própria forma sob a qual os fenômenos se oferecem em todos os lugares na natureza. A Geografia é solicitada para as realidades" (VIDAL DE LA BLACHE, 1982, p. 40). Reconhece La Blache que se estabelece, nos diferentes lugares, uma associação, fechada ou aberta, envolvendo a construção de elos de interdependência que se espraiam desde os seres inorgânicos até o âmbito do ser social, atravessando, enquanto intermediários (em duplo sentido, tanto na influência sobre os homens como sendo o prioritário âmbito da ação humana), o mundo vivo dos vegetais e animais: “Assim, as coisas se apresentam a nós em grupos organizados, em associações regidas por um equilíbrio que o homem perturba incessantemente ou, conforme os casos, retifica colocando a mão" (VIDAL DE LA BLACHE, 1982, p. 45).

O equilíbrio que abarca a natureza viva (inclusa a humanidade), estendendo-se à inorgânica compõe, exatamente, o meio. É desta forma que o geógrafo francês pretende atribuir a devida importância a uma ideia essencialmente geográfica: "a de um meio compósito, dotado de uma potência tal que pode agrupar, e manter juntamente, seres heterogêneos em coabitação e correlação recíproca. Esta noção parece ser a própria lei que rege a geografia dos seres vivos" (VIDAL DE LA BLACHE, 1959, p. 34). Comenta Ruy Moreira (2008, p. 67): “o meio geográfico é um todo diverso de seres, coisas e homens que coabitam um mesmo espaço. A coabitação é aí o aspecto fundamental". Temos, assim, uma realidade concreta da qual os animais, quando bem dotados de órgãos de locomoção, e os homens, através de sua inteligência, são capazes de opor certa resistência, mas não de escapar de sua influência: "se cogitarmos nos fios ignorados de que é tecida a teia que nos envolve, qual o organismo vivo é capaz de subtrair-lhes?” (VIDAL DE LA BLACHE, 1959, p. 34).

Desdobrando, a "escola francesa" traz ainda a explicitação da noção de meio geográfico, a partir do reconhecimento do homem enquanto um fator geográfico - nesse sentido correlato à noção de meio humano, na citação anterior de Monbeig. Evidenciado

\footnotetext{
${ }^{178}$ As quais exemplifica com a lei da gravidade e a busca de espaço por parte de qualquer espécie viva, cf, Vidal de la Blache, 1982, p. 39.
} 
quando, por exemplo, Albert Demangeon, ao delimitar sua definição de Geografia Humana, explicita a distinção entre meio físico e meio geográfico, sendo esta uma expressão mais compreensiva que "engloba não somente as influências naturais que podem-se exercer, mas ainda uma influência que contribui para formar o meio geográfico, o ambiente total, a influência do próprio homem" (DEMANGEON, 1982, p. 52). Através de sua "inteligência" e "iniciativa", o homem "torna-se um agente da natureza transformando a fundo a paisagem natural” (DEMANGEON , 1982, p. 52). Em certa medida, acredito que essa definição de meio geográfico pode ser aproximada da, mais utilizada por David Harvey (2013, p. 315), de ambiente construído: "um sistema de recurso vasto, humanamente criado, compreendendo valores de uso incorporados na paisagem física, que pode ser utilizado para produção, a troca e o consumo" ${ }^{179}$. Mais adiante, desdobraremos outros aspectos dessas categorias.

Por enquanto, compreendendo a formação de Monbeig na tradição francesa e, nessa, a centralidade da noção de meio, como expressão local da complexidade de associações entre os seres, pode-se aceitar que "tomando emprestada a ideia - lablachiana - de complexidade dos fenômenos que se entrecuzam na natureza, Monbeig elabora a noção nuclear que constitui as suas análises: o complexo geográfico" (DANTAS, 2009, p. 5), como vimos, localizado e resultado de ações recíprocas e mutáveis do meio natural e do meio humano. E Monbeig (1957, p. 9) reconhece ainda o caráter histórico deste complexo, em sua essência, na medida em que resultante da ação humana, de modo que mesmo a definição de seus elementos constitutivos básicos incorpora esta variabilidade e, por exemplo, "a variedade dos componentes do complexo geográfico é tanto maior quanto mais elevado é o grau de civilização técnica atingido pelo grupo humano". Podemos, aqui, remeter à ideia de processo geográfico ${ }^{180}$. Assim, talvez se possa

\footnotetext{
${ }^{179} \mathrm{Na}$ sequência, tomando como referência a geografia capitalista, especifica: "o ambiente construído compreende toda uma série de elementos diversos: fábricas, represas, escritórios, lojas, armazéns, rodovias, ferrovias, docas, usinas hidrelétricas, sistemas de suprimento de água e tratamento de esgoto, escolas, hospitais, parques, cinemas, restaurantes - a lista é infinita. Muitos elementos - igrejas, casas, sistemas de drenagem etc. - são legados de atividades realizadas em relações de produção não capitalistas" (HARVEY, 2013 , p. 315). Cf. ainda, por exemplo, diversas passagens obras recentes, voltadas a uma análise mais conjuntural, como $O$ enigma do capital e as crises do capitalismo, em especial capítulo "6. A geografia disso tudo". Em outra fundamentação teórica, DARDEL (2011, p. 27): "os campos, as plantações, os terraços das montanhas chinesas ou os deltas quadriculados pelos arrozais, representam diversos modos de 'construção' do espaço que exaltam a realidade geográfica".

${ }^{180}$ Problematizando a própria noção de Monbeig, e de como este remete às ações recíprocas mutáveis, Elvio Rodrigues MARTINS ("A geografia urbana e o tempo geográfico", p. 18) pontua que "a ideia de processo representa a articulação de elementos como estrutura, forma, ordem, função, determinação, influências, identidade, diferença, contradição e, sobretudo, relação. Com isso queremos apontar para a
} 
reconhecer de maneira mais decisiva, na noção de Pierre Monbeig, a introdução da processualidade e da historicidade, se não de todo ausentes, ao menos apenas parcialmente apropriadas no bojo da tradição geográfica ${ }^{181}$.

Em certa medida, é também da influência da tradição francesa (e de sua complexificação) que se depreende a centralidade atribuída à categoria de paisagem, entendida como a aparência do complexo geográfico e, em sua concepção, o ponto de partida de análise geográfica: "a paisagem é um dos elementos do complexo geográfico e o trabalho do geógrafo é decifrar este complexo" (DANTAS, 2009, p. 5). Nos termos do próprio Monbeig (1957, p. 11), “este se exprime antes de tudo na paisagem, a qual, formada una e indissoluvelmente pelos elementos naturais e pelos trabalhos dos homens, é a representação concreta do complexo geográfico. Por esta razão, o estudo da paisagem constitui a essência da pesquisa geográfica”. Vale pontuar que, enquanto aparência, a paisagem não remete apenas à apreensão da realidade pelo sujeito, não remete, por exemplo, "ao que a visão alcança, num golpe de vista", mas, sim, a uma dimensão

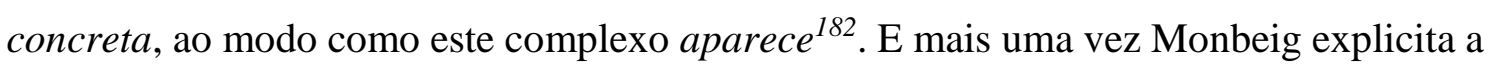
riqueza de seu pensamento ao, imediatamente, pontuar que "a paisagem não exterioriza todos os elementos constituintes do complexo", de modo que é "absolutamente indispensável que o geógrafo não se limite à análise do cenário, à apreensão do concreto" - em termos da ontologia marxiana, talvez o mais adequado seria referir ao fenomênico, ou "imediato". Nesse sentido, acentua aos geógrafos o risco de que "a limitação do campo de estudo geográfico à paisagem ameaça levar o pesquisador ao recurso exclusivo da descrição", isto é, "a paisagem é um ponto de partida, mas não um fim. Resulta do complexo geográfico, sem confundir-se com ele" (MONBEIG, 1957, p. 11).

Um elemento fundamental esta posto, e vale destacar pois me parece exatamente a riqueza da noção de complexo geográfico: este representa, em realidade, um complexo categorial, isto é, um todo articulado de categorias referidas, em essência, à dimensão topológica da realidade. É nesse sentido que compareceram, por exemplo, as categorias de meio, meio geográfico ou ambiente construído e paisagem - todas componentes do

necessidade de tomar a geografia como processo, ou simplesmente, do processo geográfico. Algo que partiria da ideias - e o seu desenvolvimento - de complexo geográfico de Pierre Monbeig”.

${ }^{181}$ COSGROVE (2011, p. 108-9), por exemplo, lembra que "Ley mostrou que a escola vidaliana, especialmente com Jean Brunhes, produziu uma degeneração da abordagem dialética na coleta $\mathrm{e}$ classificação dos fatos da paisagem que foram destituídos do contexto histórico e tratados funcionalmente ${ }^{182}$ Distinta, por exemplo, da apreensão de que "a paisagem é um conjunto, uma convergência, um momento vivido, uma ligação interna, uma 'impressão', que une todos os elementos”' (DARDEL, 2011, p. 30). 
complexo geográfico, mas sem confundir-se com ele. Nesse sentido, embora não explicitado por Monbeig, até porque esta não se apresentava exercendo papel dominante à sua época (embora não estivesse ausente), a presente discussão, em minha opinião, subentende a negação da concepção de "espaço absoluto", usual na ciência geográfica. Vejamos.

Abordando pela questão epistemológica, isto é, no âmbito da ciência geográfica, ainda que seja "recorrente observarmos a associação entre espaço e Geografia, e entre tempo e história"183, e a definição do espaço (geográfico) como o objeto da disciplina já tenha se convertido em posição hegemônica indubitável, não é esta a posição com a qual coadunamos, o que não implica negarmos a importância e, mesmo, a centralidade do espaço no interior do complexo geográfico e, por conseguinte, da ciência geográfica, na medida em que se remetem aos aspectos topológicos da realidade. Na posição teórica aqui desenvolvida, parece-me mais adequado a identificação de um complexo categorial (como já visto, de abstrações extraídas do real) que permita a visualização e o entendimento de determinações presentes no real. De outro lado, ainda, vale notar que essa recorrente associação tem poucas vezes explicitado seus fundamentos teóricos e vem trabalhando tanto com a noção de espaço absoluto ${ }^{184}$ (isto é, a cisão entre espaço e matéria, conforme explicitada teoricamente de modo clássico na física newtoniana), como na, em certa medida associada, mesmo que aparentemente paradoxal, identificação entre espaço e matéria (ou natureza ou meio).

Dada a centralidade da dimensão espacial para a geografia, a problematização da questão proposta, nos limites e propósitos da presente dissertação, pode minimamente efetivar-se apenas se nos desembaraçarmos (o que não implica na recusa) da complexa reflexão teórica em torno do conceito de espaço. Originada nas ciências físicas e na filosofia da natureza (e, essencialmente, girando em torno das noções de espaço absoluto ou relativo), tal reflexão foi apropriada pela ciência geográfica a partir de meados do século XX, quando da expansão de posições que passaram a caracterizar o espaço como o objeto primordial da disciplina ${ }^{185}$. Apesar da amplitude e importância do debate, porém,

\footnotetext{
${ }^{183}$ Elvio Rodrigues MARTINS , "Geografia e ontologia: o fundamento geográfico do ser”, p. 38.

${ }^{184}$ Tome-se o significativo (na medida em que ainda configura uma exceção) exemplo de Moraes (2000, p. 19)) que, no valioso e incomum esforço de clarificação de seus fundamentos teóricos, "mesmo sem compartilhar da visão do espaço como objeto e da pretensão de exclusividade no seu estudo" e se opondo à "coisificação do espaço", observa "que a proposição exposta não colide com a concepção newtoniana de espaço usualmente empregada pela geografia" (MORAES, 2000, p. 22).

${ }_{185}$ Neil SMITH (1988) Douglas SANTOS (2002), e Ana Fani A. CARLOS (2011) representam,
} 
"tornou-se mais um problema que uma solução o uso da categoria, já que, em si e para si, ela parece não resguardar qualquer tipo de conceito mais perene, que nos permita usá-la com tranquilidade e com um mínimo de certeza de sermos entendidos" (SANTOS , 2002, p. 17).

De todo modo, podemos iniciar pela refutação da noção de espaço absoluto, a fim de, progressivamente, estabelecermos alguns fundamentos ontológicos essenciais: “espaço absoluto, em física, refere-se a uma 'visão de contêiner' de um espaço que é imutável, interminável e inalterável. Na prática, isso se reduz a postular um conjunto de coordenadas fixas por meio das quais a matéria se move" (HARVEY, 2013, p. 437). Nesse sentido, a profunda crítica à concepção de "espaço absoluto" explicitada por Lefebvre no capítulo “A arquitetônica espacial”, em sua obra A produção do espaço, pode ser compreendida como uma das expressões específicas da crítica à especulação: "neste extremo ponto da abstração formal que o pensamento filosófico clássico (metafísico) estabelece em ontologia por decreto especulativo, ele põe o espaço 'em si', substancialmente" ${ }^{186}$. Esta concepção implica a cisão completa entre matéria e espaço ${ }^{187}$ e a afirmação da prévia existência de um espaço receptáculo a ser preenchido pelas coisas, de modo que "a crítica e a recusa do espaço absoluto equivalem à rejeição de uma representação, aquela de um continente que um conteúdo, a matéria, o corpo vem preencher" 188 .

A crítica ao "espaço absoluto", assim, corresponde à refutação de uma espécie de ser absoluto, indeterminado, que preceda as próprias coisas, e, por conseguinte, coaduna com a determinação ontológica marxiana mais geral - a identificação entre ser $e$ objetividade. Com efeito, destacou-se no capítulo anterior que, da complexa relação de Marx com Feuerbach, em especial nos momentos iniciais da constituição do pensamento marxiano, depreende-se uma conquista decisiva: a afirmação da nova ontologia calcada na objetividade, bem expressa no reconhecimento de que "um ser não-objetivo é um não-

simultaneamente, distintas sínteses, tentativas de apropriação e encaminhamento do debate referido. Quanto à apropriação da questão na ciência geográfica, Smith (1988, p. 110), por exemplo, afirma que "desde o início da década de sessenta, a concepção de espaço geográfico tem sido objeto de discussões consideráveis. Duas concepções particulares de espaço têm sido objeto de destaque: o espaço absoluto e o espaço relativo. A discussão surgiu em relação à chamada Revolução Quantitativa na Geografia, que se materializou no início da década de 60".

${ }^{186}$ Henri LEFEBVRE, “Arquitetônica espacial”, p. 1.

${ }^{187}$ Com efeito, "a história do conceito é marcada por uma contínua abstração do espaço em relação a matéria” (SMITH, 1988, p. 112).

${ }^{188}$ Henri LEFEBVRE, op. cit., p. 1. 
ser" (MARX, 2004, p. 127) enquanto refutação peremptória da filosofia especulativa e de seus desdobramentos - dentre estes, o "espaço absoluto".

Vale notar, ainda, que tal forma de apreensão de espaço como um contêiner, no qual se inserem os seres indeterminados ou onde acontecem os fenômenos, deriva ou implica na implícita afirmação da indiferença entre forma e conteúdo ${ }^{189}$ e na reafirmação da fragmentação ${ }^{190}$. Dimensões, indiferença e fragmentação, igualmente percebidas em paragens diversas do pensamento geográfico clássico, em especial no que se refere à relação entre o homem e o meio (ou natureza, ou espaço). Quanto a isto, também é válido perceber que Lefebvre enraíza-as numa prática social concreta, identifica sua "base material": "a fragmentação substitui o pensamento e o pensamento como reflexão se esfuma para desaparecer, no limite, na ação empírica de contar isto ou aquilo" ${ }^{191}$, remetendo assim ao pragmatismo da sociabilidade capitalista como raiz efetiva dessa forma de compreensão. Nesse sentido, enfim, a noção de espaço absoluto é refutada na medida em que corresponde à espacialidade de uma prática determinada, que constitui o efetivo objeto de crítica de toda a impostação marxiana. Ademais, registrar o enraizamento da concepção de espaço absoluto na prática capitalista, ou melhor, na essência da propriedade privada ${ }^{192}$, permite apontar para os fundamentos da associação aparentemente paradoxal, já comentada: a concepção absoluta de espaço, instituída, como vimos, através da cisão entre espaço e matéria, é igualmente manifestada na forma da identificação entre espaço e matéria, ou natureza. Esta identificação, enfim, talvez se fundamente no fato de que, para o proprietário privado de uma parcela da superfície terrestre, de fato aquilo que está contido por esta parcela se confunde com a mesma (ele é igualmente proprietário), já que "a propriedade privada na terra, na prática em geral registrada mediante levantamento cadastral e mapeamento, estabelece claramente a porção da superfície da terra sobre a qual indivíduos privados têm poderes monopolistas exclusivos" (HARVEY, 2013, p. 438). Não por acaso, aliás, Elvio Martins (2006)

\footnotetext{
189 "Nessa representação, o continente (formal) e o conteúdo (material) são indiferentes um ao outro e não apresentam, portanto, uma diferença discernível [apreensível]" (ib.).

190 "A indiferença torna-se separação, o conteúdo e o continente caem um fora do outro" (ib.).

${ }^{191}$ Ib., pp. 1-2. Relação, como vimos, igualmente presente em David Harvey (1980) e também acentuada por Smith (1988, p. 111): "Hoje, no avançado mundo capitalista, todos nós concebemos o espaço como vácuo, como um receptáculo universal no qual os objetos existem e os eventos ocorrem, como um quadro de referência, um sistema coordenado (juntamente com o tempo) em que toda realidade existe".

192 Como desdobra David HARVEY (2013, p. 437): "a posse da propriedade privada na terra confere poder exclusivo a pessoas privadas sobre algumas porções do globo. Isso envolve uma concepção absoluta do espaço".
} 
identifica a raiz filosófica desta identificação entre espaço e matéria na instituição da própria filosofia moderna, com Descartes e sua res extensa, como vimos anteriormente, coetânea (ou melhor, associada) ao desenvolvimento das ciências naturais (e, nestas, da física newtoniana).

Encaminhando, da crítica e refutação do "espaço absoluto como um atributo ou modo de ser absoluto, Deus”, do “espaço 'em si' definido como infinito, [que] não possui nenhum contorno porque ele não tem conteúdo" 193 , estabelece-se a inversão: "o que ocupa o espaço? Um corpo" 194 . Ou melhor, reconhece Lefebvre, na medida em que não se trata de um espaço pré-existente que possa ser ocupado, deve-se afirmar que "o corpo, com suas capacidades de ação, suas energias, faria o espaço? Sem dúvida /.../" 195 . Dimensão que não aparece, porém, como exterior ao próprio corpo: “cada corpo vivo é um espaço e tem seu espaço" ${ }^{196}$. Ainda que acentue o corpo vivo, a afirmação é válida para todas as esferas do ser, na medida em que "na natureza, inorgânica ou orgânica, as simetrias (segundo um plano ou um eixo) isto é, a existência de uma bilateralidade ou dualidade, de uma esquerda e de uma direita, de uma reflexão ou 'reflecção', ou ainda de simetria de rotação (no espaço) não são propriedades exteriores ao corpo". No que se repõe a crítica à especulação, em primeiro lugar, ao lembrarmos que esta efetiva-se exatamente na refutação do procedimento intelectivo que toma o predicado (no caso de Hegel, objeto da crítica de Marx, o pensamento), como o sujeito, invertendo a determinação real. Aqui, "não é um pensamento preexistente que impõe essas propriedades [espaciais], definíveis em termos 'puramente' matemáticos (aplicações, operações, transformações e funções), a esses corpos materiais, como supõem os filósofos" pois, em realidade, o espaço é predicado, isto é, “o corpo, os desenvolvimentos de energia, produzem o espaço e se produzem, com seus movimentos, segundo as leis do espaço" $" 197$.

E mais, "Marx, contrapondo-se à especulação, não apenas identifica ser à objetividade, mas também procura demarcar o caráter relacional da mesma, vale dizer, da constante interação objetivamente existente entre seres efetivos enquanto tais"

\footnotetext{
${ }^{193}$ Henri LEFEBVRE, op. cit., p. 1.

${ }^{194} \mathrm{Ib}$.

${ }^{195} \mathrm{Ib}$., p. 2. Com efeito, reafirma mais adiante: "a materialidade desse corpo não se atribui nem à reunião de parcelas num dispositivo, nem a uma natureza indiferente ao espaço e se repartindo nele para ocupá-lo" (ib., p. 17).

$196 \mathrm{Ib}$, p. 2.

$197 \mathrm{Ib}$.
} 
(VAISMAN , 1996, p. 127). O ser, portanto, é melhor definido como a objetividade diversa em permanente inter-relação, apontando para a multiplicidade do existente. Como, aliás, citando Hegel, igualmente afirma Lefebvre: "o aqui e agora, no sentido de Hegel, não se reduz a uma 'coisidade', mas compreende relações e movimentos" ${ }^{198}$. Assim, na medida em que todo ser é objetivo e está posto em uma malha complexa de relações com os outros seres, melhor compreendemos a afirmação supracitada da "existência de uma bilateralidade ou dualidade, de uma esquerda e de uma direita, de uma reflexão ou 'reflecção', ou ainda de simetria de rotação (no espaço)", enquanto propriedades do próprio corpo. Isto é, compreendemos a emergência do espaço enquanto dimensão da coexistência dos seres, estabelecido mesmo em suas relações - e, daqui, a afirmação de meio como definido pela coabitação dos seres, comentada anteriormente.

A referência de Lefebvre ao ser orgânico, por sua vez, permite estabelecermos, na sequência, o terceiro fundamento da noção de ser, como posta por Marx - o padecimento ou carecimento do outro: "ser sensível, isto é, ser efetivo, é ser objeto do sentido, ser objeto sensivel, e portanto, ter objetos sensíveis fora de si, ter objetos de sua sensibilidade. Ser sensível é ser padecente" (MARX, 2004, p. 128). O exemplo da aranha nos permite compreender que "ela produz, ela secreta, ela ocupa um espaço e o engendra à sua maneira, aquele da sua teia, aquele de suas estratégias e de suas necessidades"199, na medida de suas relações com os demais seres objetivos que garantem sua reprodução aqui se pondo a novidade na esfera do ser, em relação à natureza inorgânica.

Nesse sentido,

\begin{abstract}
segue-se que para um corpo vivo (à maneira da aranha, do marisco etc.) os lugares fundamentais, os indicativos do espaço, são, portanto, de início qualificados pelo corpo. O 'outro' está lá, diante do $\mathrm{Eu}$ (corpo diante de um outro corpo). /.../. Objeto de um dispêndio de energia, agressão ou desejo. /.../ O espaço qualificado em função do corpo quer dizer que ele se determina em função do que o ameaça ou o favorece ${ }^{200}$.
\end{abstract}

Se, em termos gerais, podemos seguir Lefebvre e afirmar que tanto a natureza inorgânica quanto a orgânica fazem e contém propriedades espaciais a partir de suas relações e movimentos, i. e., do caráter relacional de toda objetividade, é o carecimento de outras objetividades que estabelece a primeira forma de qualificação ${ }^{201}$ do espaço, de

\footnotetext{
${ }^{198}$ Henri LEFEBVRE, op. cit., p. 4.

${ }^{199}$ Henri LEFEBVRE, op. cit., p. 3.

${ }^{200} \mathrm{Ib}$., p. 4.

${ }^{201}$ Com efeito, na natureza orgânica "o desenvolvimento ocorre de tal maneira que os impulsos do mundo exterior no organismo, originalmente ainda simples impulsos físicos ou químicos, adquiriam a sua figura
} 
acordo com as demandas de sobrevivência e reprodução dos seres vivos. De fato, tal qualificação, desdobrada pelo filósofo francês em três aspectos - o gesto, o traço e a marca - representa manifestação de "uma inteligência do corpo", ainda que inserida no bojo de uma adaptação passiva ao ambiente - "a explosão, a imagem e a orientação do corpo", referindo-se ao fato de que "muito cedo, na vida animal, o traço e a marca têm um papel. Os lugares se marcam e remarcam" ${ }^{202}$, de início com aquilo que os animais dispõem, "excrementos, urina, saliva etc.", para converter-se, posteriormente, no "traço".

Em suma,

o organismo vivo só tem sentido e existência considerado com seus prolongamentos: o espaço que ele alcança, que ele produz (seu 'meio', termo corrente que reduz a atividade à inserção passiva numa materialidade natural). Todo organismo vivo se reflete, se refrata, nas modificações que ele produz em seu 'meio', seu 'ambiente': seu espaço ${ }^{203}$.

Dois elementos, então, podem ser assentados. Em primeiro lugar, estabelecidas as determinações ontológicas básicas - a objetividade, seu caráter relacional e o padecimento, por parte dos seres orgânicos - podemos assumir, na perspectiva marxiana, a delimitação de meio, conforme explicitada no início deste tópico: como o elo instaurado entre os seres a partir e pelas suas relações. Em segundo lugar, podemos também reconhecer o espaço como, inicialmente, uma dimensão do meio, na medida em que produzido pelos seres e objetos nas suas relações, isto é, espaço como uma dimensão atinente à objetividade relacional (e padecente). Por configurar uma categoria da existência de todos os seres, ademais, converte-se também numa categoria atinente à subjetividade - daí, nas formas primárias do ser social, Lefebvre referir-se à qualificação e à uma inteligência do corpo.

Aqui vale uma advertência com o objetivo de ressaltar que, embora possamos reconhecer espaço, para o ser social, como "elemento constituinte no ato da cognição do mundo" (MARTINS, 2006, p. 37), isto é, que "o que pensamos ser espaço e tempo são, na verdade, a ferramenta que possuímos para sistematizar a nossa relação com o mundo da maneira como hoje ele se nos apresenta" (SANTOS, 2002, p. 29), e ainda que aceitemos um adendo ao pensamento kantiano - assim como espaço, "a noção de tempo

objetiva em modos de manifestações especificamente biológicos; é assim que vibrações do ar, que como tais originalmente tinham um efeito puramente físico, convertem-se em sons; é assim que reações químicas convertem-se em cheiro e sabor; é assim que nos órgãos da visão surgem as cores etc." (György LUKÁCS, 2013, p. 203).

${ }^{202}$ Henri LEFEBVRE, op. cit., p. 3.

${ }^{203} \mathrm{Ib} ., \mathrm{p} .17$. 
não é apriorística mas, sim, socialmente construída" (SANTOS, 2002, p. 30, nota 14) ou, diretamente, "espaço é atributo do ato de cognição do mundo. Mas como tal, não é um dado a priori, como queria Kant, e sim algo que emerge como construção social, um atributo cultural, uma forma de ver e compreender o mundo" (MARTINS , 2006, p. 37) - não me parece, pela posição aqui desdobrada e não que seja, necessariamente, essa a dos autores citados, possível abstrair o espaço enquanto elemento constituinte da própria realidade. Em suma, fazemos o esforço de, ao reconhecer que os conceitos de tempo e espaço são social e culturalmente construídos, não enveredarmos pelo relativismo ou compreendê-los tão somente (como o "na verdade", de uma passagem acima, pode levar a conceber) como categorias da cognição.

Sem desconsiderar ou diminuir toda a reflexão filosófica empreendida em torno das noções de espaço ${ }^{204}$, a noção de espaço relacional parece mais adequada aos princípios ontológicos evidenciados (e ainda retomaremos tal demonstração). Não por acaso, com efeito, num dos textos que influenciam Marx à crítica da filosofia especulativa, como versão específica da crítica da religião, temos que "o espaço e o tempo são as formas de existência de todo o ser. Só a existência no espaço e no tempo é existência" (FEUERBACH, 1988, p. 26), isto é, "o espaço e o tempo são as formas de revelação do infinito real' (FEUERBACH, 1988, p. 27). Afirmações acompanhadas da negação das concepções absolutas de espaço e tempo, associadas à filosofia especulativa: "a filosofia especulativa fez do desenvolvimento sem o tempo uma forma, um atributo do absoluto" (FEUERBACH, 1988, p. 27), ou então, "uma sensação intemporal, uma vontade intemporal, um pensamento intemporal, um ser intemporal são quimeras" (FEUERBACH, 1988, p. 26) - quimeras igualmente se substituíssemos por aespacial. Enfim, podemos, a partir do estabelecido, evitar tanto a dissociação absoluta de espaço e matéria, como também sua identificação, demarcando, por fim que "matéria e corpo, ou mesmo natureza, são aspectos distintos entre si e que designam diferentes dimensões da realidade, e o espaço tem outra posição dentro deste cenário, e que não se confunde definitivamente com matéria, corpo ou natureza" (MARTINS, 2007, p. 36).

Nesse sentido, parece-me possível compreender o espaço (tomado como relacional), como uma das categorias, a central, do complexo geográfico, tal como

\footnotetext{
${ }^{204}$ Até porque me parece válida a afirmação de Harvey (1980, p. 5) de que "o problema da correta conceituação do espaço é resolvido através da prática humana em relação a ele. Em outras palavras, não há respostas filosóficas para as questões filosóficas que surgem sobre a natureza do espaço - as respostas estão na prática humana”. Mais adiante, concretizamos esta questão.
} 
vínhamos problematizando, associada com as, já expostas, de meio, meio geográfico e paisagem, além de outras. Numa palavra, enquanto "fundamento do real (tanto quanto o histórico), a geografia não é sinônimo de espaço, e sim ele, o espaço, é um dado do geográfico" (MARTINS, 2007, p. 36). Em outro momento, reafirma-se “Geografia não é o mesmo que espaço, e possui um conteúdo de significado em que espaço é uma das categorias, entre outras, que a constitui”"(MARTINS, 2007, p. 38).

Nesse momento, em especial do ponto de vista de certas correntes do marxismo, poder-se-ia interpor o questionamento quanto às razões últimas do nosso intento reconhecer a existência e as categorias constituintes de um complexo geográfico - e, ainda, quanto à sua própria designação como geográfico. Questionamento que nos permite encetar uma última via reflexiva nesse item, retomando aspectos já mencionados e articulando-os com outros fundamentos filosóficos essenciais de Marx, principalmente os concernentes ao ser social (nesse sentido, retomamos as caracterizações de Lukács, a primeira de nossas "inspirações").

Com efeito, ainda que a rigorosidade terminológica seja um momento fundamental do trabalho científico, eixo essencial do processo de desantropomorfização, conforme assentado, pelo menos, desde a teoria baconiana dos ídolos, podemos até aceitar, aqui, que o nome não é mais importante. De fato, mesmo quanto ao termo geografia, muitos foram os sentidos a ele atribuídos desde seu aparecimento no contexto da cultura grega, em toda a tradição ocidental. Isto é, "o rótulo geografia é um dos mais antigos e difundidos na história do conhecimento, remontando à Antiguidade Clássica" (MORAES, 2000, p. 14), mas "a forma de organização e tratamento" dos conteúdos se diversifica nos momentos históricos e nas diferentes sociedades, "impedindo que se trace uma linha de continuidade no estabelecimento do campo disciplinar" (MORAES, 2000, p. 14). Porém, é possível reconhecer que "diferentes povos, em variadas épocas, utilizaram-no para nomear determinados conjuntos de conhecimentos e indagações geralmente referidos à superfície da Terra e à descrição dos lugares terrestres" (MORAES, 2000, p. 14).

Em outras palavras, independente do termo utilizado, ou mesmo se a este aspecto se referiram de maneira relativamente autônoma, o central é perceber que todos os indivíduos e agrupamentos humanos, inserindo-se em meios únicos e específicos, tiveram, e têm, cotidiana e constantemente, de dar conta do complexo categorial que aqui problematizamos - isto é, dos lugares, de suas relações e das relações com as categorias 
topológicas emergentes de sua relação com a natureza. Isto é, "entendida no seu mais amplo sentido como ciência da Terra, a geografia é um dos mais velhos ramos do saber humano" e isto porque "o seu aparecimento liga-se à aspiração, que tiveram os homens recém-saídos da vida selvagem, de deixar fixada a recordação dos lugares em que viveram, numa área variável segundo as necessidades da vida e os meios disponíveis de locomoção" (PEREIRA, 1945, p. 1477). O mesmo autor especifica:

\begin{abstract}
desde que a caravana humana começou a desfilar através dos séculos vem empregando esforços para conhecer a superfície do Globo, levada muito mais por tendências profundas do que pelo espírito de aventura, muito mais pela necessidade de assegurar os meios de subsistência do que pela simples e pura atração de encontrar ou atingir terras desconhecidas (PEREIRA, 1945, p. 14789).
\end{abstract}

Tais categorias, aliás, são diversamente constatadas pelos próprios autores clássicos da tradição acadêmica, podendo dali serem resgatadas de sua inserção em fundamentos teóricos distintos, em geral associados ao positivismo. Desdobra então o geógrafo carioca, por exemplo, de que modo o saber geográfico fundamenta-se num conjunto de demandas postas pela prática humana, tais como localização, direção, distância, referência, observação e orientação. Quanto à especificidade do ser social, nesse sentido, podemos compreender que, inserido na prática humana, temos a inevitável ampliação e complexificação da inteligência do corpo, acima referida, e da dinâmica de produção do "meio" e do espaço.

Ora, este saber específico se desenvolve, como mediação fundamental da prática, na medida em que corresponde à apropriação de uma parcela específica da realidade, um complexo específico. Tal questão se evidencia, a meu ver, quando acompanhamos a reflexão encetada por Kosic (1976, p. 23), ao reconhecer que "o homem vive em muitos mundos mas cada mundo tem uma chave diferente, e o homem não pode passar de um mundo para o outro sem a chave respectiva, isto é, sem mudar a intencionalidade e o correspondente modo de apropriação da realidade". Ou seja, se seguirmos o pensador polonês, apropriando-se de reflexão marxiana, temos que o desenvolvimento objetivo do mundo humano, isto é, da atividade objetiva dos homens, leva ao desenvolvimento do sentido correspondente. "O processo de captação e descobrimento do sentido da coisa é ao mesmo tempo criação, no homem, do correspondente sentido, graças ao qual ele pode compreender o sentido da coisa. É possível, portanto, compreender o sentido objetivo da coisa se o homem cria para si mesmo um sentido correspondente" (KOSIC, 1976, p. 23). Na sequência, Kosic é ainda mais assertivo: “cada grau de conhecimento humano sensível 
ou racional, cada modo de apropriação da realidade, é uma atividade baseada na práxis objetiva da humanidade e, portanto, ligada a todos os outros vários modos, em medida maior ou menor" (KOSIC, 1976, p. 23-4), tais como a arte e a filosofia.

Tal problematização aponta, de início, para o caráter histórico-social dos homens e, portanto, do mundo humano, bem como permite desdobrar um conjunto amplo de questões associadas à nossa reflexão. Pode-se, por exemplo, perceber que a prática humana depara-se com um mundo espacialmente ordenado - segundo lógicas e dinâmicas específicas e próprias à natureza dos seres em questão. Esta dimensão específica de sua ordenação deve ser apropriada, no bojo do próprio processo através do qual os homens produzem uma nova realidade humano-social e, por conseguinte, uma nova ordenação. Emerge, assim, toda uma dimensão particular, com lógicas especiais, que devem e são apropriadas na forma de uma consciência específica - o sentido de localização, apontando para a existência de uma objetividade específica, um conjunto de modos de ser, isto é, de categorias.

De outro lado, as observações de José Veríssimo da Costa Pereira nos remetem, essencialmente, ao ponto de partida único de Marx, à sua posição ontológica. Isto é, como vimos, seu "modo de considerar as coisas não é isento de pressupostos. Ele parte de pressupostos reais e não os abandona em nenhum instante". E mais, "ali onde termina a especulação, na vida real, começa também, portanto, a ciência real, positiva, a exposição da atividade prática, do processo prático de desenvolvimento dos homens" (MARX; ENGELS, 2007, p. 94-5).

Comecemos, então, pela vida real ${ }^{205}$, isto é, devemos partir dos homens vivos e ativos. Que, para manterem-se vivos e confirmarem sua atividade, se objetivarem, devem se apropriar das demais formas de ser em sua objetividade concreta. É aqui que, associadas, as noções de espaço e tempo ganham concretude e efetividade:

tempos e ritmos sociais se superpõem e coexistem com tempos e ritmos naturais, cosmológicos, mas a definição, o controle e a medição de tempos, ritmos e espaços humanos sempre estiveram ligados ao processo de produção de bens materiais e reprodução das relações entre produtores (FERRARI, 2012, p. 118).

\footnotetext{
205 Ademais, talvez tenha sido esta exatamente a postura de Marx, do que se depreende a constatação de uma pretensa "ausência" quanto ao espaço: "Marx não cuidou sistematicamente do valor de uso do espaço, mas há várias referências a ele espalhadas por toda sua obra. Seu tratamento dele n'O capital, por exemplo, é baseado no puro bom senso, sem apelo a nenhuma teoria particular do espaço" (HARVEY, 2013, p. 436).
} 
Mesmo sem negar toda a complexa reflexão filosófica sobre espaço e tempo, deve-se reconhecer, por exemplo quanto a este último, que "independente de filósofos e teóricos em geral conseguirem, ou não, definir com clareza o que é o tempo, a humanidade percebeu, apreendeu intervalos de tempo definidos na e pela atividade prática dos homens na produção da vida material e espiritual" (FERRARI, 2012, p. 114). Também quanto ao espaço, remetamos a "como a prática social e cotidiana resolve, com aparente tranquilidade e perfeição, os mistérios filosóficos profundos relativos à natureza do espaço e às relações entre o processo social e as formas espaciais" (HARVEY, 1980, p. 5) Alguns aspectos merecem ser desdobrados, e nos obrigam a tomar espaço e tempo como dimensões associadas, pois, com efeito, assim são tomados na prática humana.

Em primeiro lugar, inserido na prática humana concreta, vale perceber que tempo, para além de toda especulação, "nunca nos é dado como tempo, ele nos é dado na experiência e na existência como duração, sucessão, permanência, ritmo etc. São sempre tempos de algo, a saber, do movimento da matéria" (MARTINS, 2009, p. 24). Tempo, assim, refere-se, inicialmente, à observação de regularidades e repetições, de ciclos, no interior da objetividade natural. Com efeito,

a apreensão da regularidade dos fenômenos, da regularidade dos intervalos de tempos entre esses fenômenos torna-se uma das medidas da organização social a necessidade de sobrevivência exige, ensinando, em condições particulares da autoatividade humana, a percepção do início e do fim de intervalos de tempo, de períodos decorridos entre um fenômeno e outro (FERRARI, 2012, p. 114).

Assim, "tempo é periodicidade percebida, cujo metrônomo é a atividade e a autoatividade dos homens no processo de produção material. A percepção de tal periodicidade define e organiza atividades como movimento regular ordenado de coisas no tempo e no espaço" (FERRARI, 2012, p. 115). Do mesmo modo portanto, no bojo da prática humana, impôs-se a necessidade de reconhecer o movimento regular, as relações não apenas dos seres e processos que se sucedem, mas dos que coexistem, que coabitam. Os homens são obrigados a reconhecer a localização dos fenômenos e suas relações, isto é, sua distribuição, bem como a distância e a densidade de cada ser, processo ou relação que garante sua sobrevivência e reprodução. Em suma, a reconhecer a espacialidade contida na objetividade. Estamos aqui, portanto, próximo à noção de espaço relacional, conforme proposto por Harvey (1980, p.5): “espaço tomado, à maneira de Leibniz, como estando contido em objetos, no sentido de que um objeto existe somente na medida em que contém e representa dentro de si próprio as relações com outros objetos”. 
Concretizemos este ponto, com o que retornamos aos pressupostos reais, que não se abandona em nenhum instante ${ }^{206}$, e reconhecemos o esforço precursor de Armando Corrêa da Silva (1986, p. 29) na tentativa de instituir, ontologicamente, as categorias da geografia e, como já dissemos, "de todas, a mais geral - e que inclui as outras - é o espaço". Este caráter mais geral do espaço pode ser depreendido, nos quadros da reflexão intentada, de sua validade para todas as esferas do ser. E, com efeito, "a ontologia geral ou, em termos mais concretos, a ontologia da natureza inorgânica como fundamento de todo existente é geral pela seguinte razão: porque não pode haver qualquer existente que não esteja de algum modo ontologicamente fundado na natureza inorgânica" (LUKÁCS, 2012, p. 27). Na medida em que a objetividade relacional é a determinação mais geral, pode-se reconhecer que o espaço relacional põe-se efetivamente como a categoria mais geral, universal (nesse sentido).

Encaminhando, se "para viver, precisa-se, antes de tudo, de comida, bebida, moradia, vestimenta e algumas coisas mais. O primeiro ato histórico é, pois, a produção dos meios para a satisfação dessas necessidades, a produção da própria vida material" (MARX; ENGELS, 2007, p. 33), podemos especificar que "o primeiro fato geográfico, além de toda imaginação, é o da produção do espaço do beber, vestir, alimentar-se e habitar" (SILVA, 1986, p. 29). Nesse aspecto, creio ser extremamente frutífero remetermos à geografia das necessidades vitais básicas, de Jean Brunhes. Quanto às duas primeiras necessidades apontadas por Marx e Engels, com efeito, o geógrafo francês pontua que "o reabastecimento de água permanece sendo o mais constante e o mais grave de todos os problemas quotidianos. Por toda a parte, a água rege soberanamente a atividade humana" (BRUNHES, 1962, p. 47). E o exemplo dos nômades, "aqueles que parecem ser os mais independentes das condições locais e que escapam ao aprisionamento geográfico de nossa vida sedentária", confirma a "tirania da água: todas as suas trilhas, todos os seus itinerários, todas as suas incursões devem, antes de tudo, levar em conta os pontos de água" (BRUNHES, 1962, p. 47). Já no que se refere à alimentação, esta "é

\footnotetext{
${ }^{206} \mathrm{O}$ caráter inapelável dos pressupostos marxianos nos impede, nesse ponto, de acompanharmos os esforços de construção e explicitação categoriais tanto de Douglas SANTOS (2004) como de Elvio R. MARTINS (1998) (em especial na sua última parte). Quanto ao primeiro, por exemplo, no interior de propósitos didáticos, perceba-se o abandono desses pressupostos ao recorrer ao recurso "da nossa imaginação", com a criação de um "personagem qualquer": "primeiro passo: nosso personagem foi abandonado num lugar, para ele, completamente desconhecido" (p. 4), a partir do qual se enceta a tentativa de observar "suas atividades hipotéticas" para "reconstruir e dar sentido aos conceitos relacionados às ideias de paisagem, território e região" $(i b)$. Vimos já, em outro momento, como Marx recusa esse "retorno" a um "ponto de partida imaginário".
} 
constituída de produtos vegetais ou animais, produtos provenientes, em sua totalidade, de seres que ocupam um lugar na superfície do globo" e "todas as vezes que os homens se desalteram ou se alimentam, portanto, aproveitam-se de fatos da superfície por eles modificada; e, pela repetição ininterrupta de suas refeições, acarretam modificações geográficas incessantes" (BRUNHES, 1962, p. 47). Ambas compõem, assim, "dupla série de fenômenos geográficos, ligados à Geografia da alimentação" (BRUNHES, 1962, p. 48). Quanto às vestimentas, outra necessidade vital, em relação às outras, "são, sem dúvida, os menos dependentes do quadro geográfico" (BRUNHES, 1962, p. 49), pois, ainda que se relacionem com "determinados produtos animais ou vegetais" e, por conseguinte, seja dependente do quadro natural, "uma vez confeccionadas, tem certa duração. Além disso, as vestimentas, por definição, são móveis e transportáveis: não estão fixas em um ponto do solo, como a habitação" (BRUNHES, 1962, p. 49).

Com efeito, é no que se refere à habitação que se evidencia, ainda segundo Brunhes, um fenômeno geográfico por excelência: "a habitação não precisa ser quotidianamente renovada; mas é fixa, ocupa um ponto preciso no espaço. /.../. Fenômeno localizado e fixo, a habitação é, por excelência, um fenômeno geográfico. /.../. À habitação é devido um lugar excepcional na hierarquia dos fatos humanos" (BRUNHES, 1962, p. 49) ${ }^{207}$. Pierre Monbeig, por sua vez, não apenas aceita a centralidade da habitação, enquanto fenômeno geográfico, como permite ampliar seu significado, isto é,

Edificando um abrigo para sua família e para si próprio, ele [o homem] constrói ao mesmo tempo edifícios que lhe sirvam no trabalho: para guardar suas colheitas, instrumentos de trabalho, animais, viaturas etc. Assim, a casa não é unicamente essas quatro paredes e esse teto sob os quais dorme a família: é todo um conjunto de construções que constituem, nas mãos dos homens, um verdadeiro instrumento de trabalho agrícola e cujo arranjo se concebe em função desse trabalho. A casa participa estreitamente, pois, do genêro de vida (MONBEIG apud DANTAS, p. 12.

Razão pela qual, assertivamente, "pode-se dizer que é o habitat a categoria que abrange o conjunto dessas necessidades reais" (SILVA, 1986, p. 29) ${ }^{208}$ supracitadas. O habitat aparece, assim, como a segunda categoria geográfica, e sua reprodução e difusão como respectivos fatos geográficos. Quanto a esta categoria, grifemos, de um lado, dada sua associação com a geografia da alimentação, emerge a ideia de sítio, ou situação ou posição, na medida em que se refere, por exemplo, às demandas postas pela tirania da

${ }^{207} \mathrm{Ib}$.

208 Também Pierre GEORGE (Sociologia e geografia, p. 29) aponta que "as relações residenciais constituem a forma mais simples dentre as relações, sendo geralmente definidas em geografia pelo termo de habitat". 
água ou pelos pontos de obtenção de alimentos, ou seja, à questão da distribuição dos fenômenos necessários à vida. Enquanto ambiente construído, ademais, a passagem de Monbeig evidencia, mais uma vez, tanto o caráter histórico do habitat, quanto sua articulação pelas necessidades e demandas postas pelo trabalho.

Quanto a este último aspecto, evidencia, assim, a noção de totalidade hierarquizada que anteriormente discutíamos. A geografia humana é, sem dúvida, nucleada pelas necessidades de produção e reprodução da vida humana. Ponto no qual devemos atentar que a produção e reprodução da vida humana envolvem, de maneira central, diversas formas de produção espiritual. Lukács, por exemplo, é explícito:

\begin{abstract}
A essência do trabalho consiste precisamente em ir além dessa estabilização dos seres vivos na competição biológica com seu meio ambiente. O momento essencial da separação é constituído não pela fabricação de produtos, mas pelo papel da consciência, a qual, precisamente aqui, deixa de ser mero epifenômeno da reprodução biológica: o produto, diz Marx, é um resultado que já no início do processo existia 'na representação do trabalhador', isto é, no plano ideal (LUKÁCS, 2007, p. 228-9).
\end{abstract}

Papel ativo da consciência que se manifesta, como vimos, tanto na reprodução intelectual do existente, na subjetividade receptora, como na colocação de finalidades específicas, na subjetividade proponente. E ambas se explicitam, assim como o próprio ambiente construído, históricas e sociais. Aqui, por exemplo, poderíamos retomar a categoria de paisagem, já mencionada. No entanto, aqui adentramos num conjunto amplo de questões, que configuram praticamente uma ausência no seio da tradição geográfica e, também, do marxismo. Isto é, das relações entre a subjetividade, a individualidade, e o meio geográfico. Pierre Monbeig é, mais uma vez, pioneiro no sentido de apontar a necessidade de se aprofundar as discussões sobre a temática, constatando os limites de sua discussão no âmbito da tradição disciplinar. Ainda que diversos geógrafos importantes, como Max. Sorre e André Cholley, por exemplo, reconhecessem a "necessidade de não subestimar os fatores psicológicos", isto é, que "modos de sentir e modos de pensar têm seu lugar na história das civilizações" (MONBEIG, 1957, p. 26), é imperioso reconhecer que os trabalhos geográficos oferecem

ao leitor um tesouro de informações, quer quanto às condições físicas das regiões em que vivem os grupos humanos, quer sobre o comportamento material de tais grupos. mas o leitor, que não é necessariamente um geógrafo e pode muito bem ser um espírito curioso, por gosto ou por necessidade, não encontrará o que esperava encontrar: o homem, com suas maneiras particulares de pensar e de sentir. Estas estão ausentes, como se se tivesse esquecido que são partes integrantes dos gêneros de vida (MONBEIG, 1957, p. 27). 
As razões últimas deste "esquecimento" poderão ser melhor desdobradas no último capítulo, atente-se à riqueza de Monbeig, que acusa uma "desumanização" da ciência, que fala apenas "de um homem-produtor ou de um homem-habitante", mas não de um "homem-que-pensa", bem como reconhecer que "é bem verdade que os geógrafos não se acham preparados para o estudo das mentalidades" (MONBEIG, 1957, p. 29), mas, de todo modo,

\begin{abstract}
Torna-se necessário que o homem seja verdadeiramente considerado como outra coisa além de uma casa, de um trator, de uma estatística. Se o homem, o homem em sociedade, constitui o centro da Geografia Humana, deve aparecer de maneira total, com seus modos de vida e com seus modos de pensar, que afinal se confundem. A limitada tarefa dos geógrafos deve consistir em explicar a parte dos fatores geográficos na formação e na evolução dos modos de pensar, e das influencias que eles exercem sobre os modos de vida e o peso que estes representam sobre aqueles. Dar mais atenção a estas pesquisas significará enriquecer a contribuição que a Geografia Humana pode ser capaz de trazer ao conhecimento do social (MONBEIG, 1957, p. 32).
\end{abstract}

Em mais esta rica passagem, Monbeig não apesar insiste na necessidade e importância de considerar o homem em sua globalidade, nas diversas dimensões que compõem sua existência - no que, inclusive, adianta certos aspectos do movimento de renovação (vimos, por exemplo, Lacoste criticando o "homem-habitante" de La Blache e Amélia Damiani pontuando a necessidade de abordar a produção do homem) e, também, das críticas ao movimento de renovação (por exemplo, as materializadas nos PCN's sobre a incapacidade da "geografia marxista" em abordar fenômenos psicológicos, e mesmo o reconhecimento de Ruy Moreira de que o movimento de renovação restringiu-se ao trabalho enquanto dimensão econômica, e outros apontando o economicismo das críticas à ciência geográfica), como pontua os elementos mais específicos que os geógrafos devem se atentar. No entanto, tal intento, me parece, apenas pode efetivar-se na medida em que esclarecer rigorosa e coerentemente o próprio entendimento de homem e individualidade, ou subjetividade. Com efeito, continuar desdobrando esta questão - o ponto central de nossa pesquisa - implica apreender a individualidade humano-social, em realidade, como constituída num processo de individuação, isto é, em resgatar sua compreensão no estatuto ontológico marxiano. Nos encaminhamos, assim, ao último capítulo de nossa dissertação. 


\section{CAPÍTULO 4 - GEOGRAFIA DO PROCESSO DE INDIVIDUAÇÃ̃}

Enquanto no capítulo precedente buscamos articular os dois primeiros capítulos de nossa dissertação, evidenciando algumas consequências dos fundamentos ontológicos marxianos para refletirmos sobre a ciência geográfica, neste momento conclusivo objetivamos articular os capítulos dois e três, isto é, retomar a acepção marxiana da individualidade humano-social e do processo de individuação, associando com a verificação da dimensão geográfica desses elementos. Assim, em primeiro lugar caracterizamos o que se pode entender por processo de individuação, na sua intrínseca relação com o meio, e, na sequência, intentamos abordar sua geografia.

\subsection{A SUPERAÇÃO DAS “BARREIRAS NATURAIS" E O PROCESSO DE INDIVIDUAÇÃO}

A unidade primária da esfera do ser social, conforme reconhecida a partir da crítica à filosofia especulativa, "é o indivíduo compreendido como indivíduo real, de carne e osso, como exemplar da espécie biológica, como parte da natureza" (SCHAFF, 1967, p. 59), nos termos de Marx: “o homem efetivo, corpóreo, com os pés bem firmes sobre a terra, aspirando e expirando suas forças naturais" (MARX, 2004, p. 126). Nesse sentido, "essa sua constituição já faz dele um complexo, pois essa é a estrutura básica de todo ser vivo, até do mais primitivo" (LUKÁCS, 2013, p. 203), daí se depreendendo, desde o nível mais imediato, a assertividade da apreensão do ser social como um complexo de complexos.

Complexo orgânico resultante da evolução das formas naturais orgânicas, no intrincado e longo processo de adaptação aos ambientes naturais, o indivíduo humano de carne e osso, tal como estas formas de vida, mostra-se, de início, condicionado e limitado por sua estrutura natural interna derivada de sua espécie e pela natureza exterior, pelo ambiente natural, como vimos, configurado enquanto uma complexa interação entre as diferentes esferas do ser e associados de maneira inextricável (retome-se a noção de meio). 
Como todos os seres naturais vivos, os indivíduos humanos também resultam do desdobrar-se das formas naturais, do movimento evolutivo da vida, do qual eles herdam, por assim dizer, uma determinada estrutura corpórea, dotada de atributos e necessidades, e um ambiente natural externo. Com o qual forçosamente têm de se pôr em relação para manter suas próprias vidas (TEIXEIRA, 1999, p. 179).

Isto significa, essencialmente, que "a despeito de todas as interações sempre presentes entre ser vivo e entorno, o momento predominante aqui certamente é como o entorno influi nos seres vivos, como ele promove, permite ou impede sua reprodução" (LUKÁCS, 2013, p. 202) Nos termos marxianos: o homem, "enquanto ser natural, corpóreo, sensível, objetivo, ele é um ser que sofre dependente e limitado, assim como o animal e a planta, isto é, os objetos de suas pulsões existem fora dele, como objetos independentes dele" (MARX, 2004, p. 127).

Como já pontuado, porém, é evidenciado pelas críticas marxianas da política e da economia política as outras determinações ontológicas do ser social. De modo que esta base fisiológica é tão somente a base insuprimível sob a qual se ergue um conjunto mais amplo de complexos a conformar o ser social e desdobrar a individualidade humanosocial, na medida em que o homem "como ser natural, e como ser natural vivo, está /.../ munido de forças naturais, de forças vitais, é um ser natural ativo" (MARX, 2004, p. 127), ou seja, tem como origem o trabalho social. Em outras palavras, tal conjunto constitui-se progressivamente na exata medida em que a atividade objetiva, social $e$ consciente apropria-se desses objetos exteriores, transforma-os ao objetivar a consciência, e, assim, produz o mundo humano, afastando, portanto também progressivamente, os condicionamentos e limites naturais (tanto de sua natureza interior como exterior). Em uma palavra, a auto-produção humana efetiva um processo que Marx caracterizou, em diferentes momentos, como de "afastamento das barreiras naturais".

É nesse sentido, em primeiro lugar, que "a história nada mais é do que o sucederse de gerações distintas, em que cada uma delas explora os materiais, os capitais e as forças de produção a ela transmitidas pelas gerações anteriores" e, nessa transmissão, "por um lado ela continua a atividade anterior sob condições totalmente alteradas e, por outro, modifica com uma atividade completamente diferente as antigas condições" (MARX; ENGELS, 2007, p. 40), configurando, portanto, a história um interminável processo de desenvolvimento da atividade e das forças produtivas. E, se levarmos em consideração a discussão já realizada de que as forças produtivas, em realidade, correspondem às capacidades de manifestação ativa dos indivíduos, elucida-se outra 
colocação de Marx e Engels ao anotarem que as condições de auto-atividade dos indivíduos, "em cada fase, correspondem ao desenvolvimento simultâneo das forças produtivas, sua história é ao mesmo tempo a história das forças produtivas em desenvolvimento e que foram recebidas por cada nova geração e, desse modo, é a história do desenvolvimento das forças dos próprios indivíduos" (MARX; ENGELS, 2007, p. 68).

Trata-se, assim, de um processo de desenvolvimento dos indivíduos, isto é, de um processo de individuação, enquanto face específica e central do próprio desenvolvimento do gênero humano. O que se pode perceber, em realidade, é que o desenvolvimento da ontologia marxiana, em especial a partir da apreensão da centralidade da atividade vital consciente, faculta-o complexificar e compreender as bases materiais e concretas da leitura do processo civilizatório efetuada por Hegel - da modernidade como emancipação da esfera privada em relação à vida pública e, por conseguinte, da sociedade civil moderna como o reino do privatismo - aceita em linhas gerais, como vimos no segundo capítulo, por Marx no bojo mesmo da superação de sua especulatividade. A fim de evidenciar não se tratar de um desvio de juventude, façamos uma incursão breve em outros textos marxistas, posteriores, que simultaneamente comprovam a manutenção e complexificação dessa leitura e terminam por contribuir para caracterizar, de modo inicial, este processo - enquanto processo de afastamento das "barreiras naturais".

Iniciamos, assim, através de Engels que, no clássico $A$ origem da família, da propriedade privada e do Estado ${ }^{209}$, ao concluir sua análise acerca da organização gentílica iroquesa, em grande parte fundamentada nos originais estudos de campo de Lewis Morgan, fundador da antropologia ${ }^{210}$, realiza um balanço interessante com o qual podemos iniciar nossas considerações acerca do processo de individuação. Aponta, ali, a grandeza e os limites da organização gentílica fundada na consanguinidade e sintetizada em seus indivíduos.

No primeiro aspecto, temos, por exemplo, de um lado a ausência dos sentimentos (e, portanto, indivíduos) abjetos que caracterizam a, em seus termos, civilização e, de outro, o vigor e o caráter exemplar dos indígenas. Exclama, na conclusão de sua análise:

\footnotetext{
${ }^{209}$ Obra que demanda, a nosso ver, incorporação mais efetiva no âmbito da ciência geográfica, intento ao qual, aliás, em parte nos dedicamos em nossa monografia Geopolítica e/na geografia didático-escolar. ${ }^{210}$ Momento no qual tal ciência se associa intimamente com a geográfica, segundo Horacio CAPEL (1989, p. 23): "Pocas ciências sociales presentan tal cantidad de problemas comunes con la geografia como la antopología /.../. Y quizás con ninguna outra - aparte de la historia - ha habido tan numerosos contatos en los momentos iniciales del desarrollo de estas disciplinas".
} 
"Admirável essa constituição da gens, com toda a sua ingênua simplicidade! Sem soldados, policiais, nobreza, reis, governadores, prefeitos ou juízes, sem cárceres ou processos, tudo caminha com regularidade. Todas as querelas, todos os conflitos são dirimidos pela coletividade a que concernem" (ENGELS, 1982, p. 106). Trata-se, por conseguinte, de uma sociedade na qual "todos são iguais e livres, inclusive as mulheres. Ainda não há lugar para escravos e, como regra geral, não se subjugam tribos estrangeiras" (ENGELS, 1982, p. 107), de modo que, ausentes "os interesses mais vis a baixa cobiça, a brutal avidez de prazeres, a sórdida avareza, o roubo egoísta da propriedade comum" (ENGELS, 1982, p. 109), é o surgimento (objetivamente fundado) destes que atua na dissolução da sociedade gentílica e na inauguração da "nova sociedade civilizada, a sociedade de classes". Com efeito, ainda reconhece: "que homens e que mulheres produziu semelhante sociedade é o que podemos ver na admiração de todos os brancos que lidaram com índios não degenerados, diante da dignidade pessoal, da retidão, da energia de caráter e da intrepidez desses bárbaros" (ENGELS, 1982, p. 107).

Porém, indica Engels, "este é um aspecto da questão. Não esqueçamos, todavia, que essa organização estava fadada a perecer” (ENGELS, 1982, p. 108); os limites dessa grandeza são facilmente reconhecíveis, para Engels, e se manifestam, de início, na subordinação dessa sociedade ao meio natural ao qual pertencem:

O regime da gens, no apogeu, como o vimos na América, supunha uma produção extremamente rudimentar e, por conseguinte, uma população muito disseminada por um vasto território - e, portanto, sujeição quase completa do homem à natureza exterior, que lhe aparecia como incompreensível e alheia (o que se reflete na puerilidade de suas ideias religiosas) (ENGELS, 1982, p. 108).

Subsunção ao meio, restrição das forças produtivas que, para os indivíduos concretos, se manifesta na forma de seu condicionamento pelo grupo natural, consanguíneo no qual se insere, isto é,

A tribo era a fronteira do homem, para os estranhos como para si mesmo: a tribo, a gens e suas instituições eram sagradas e invioláveis, constituíam um poder superior dado pela natureza, ao qual todo indivíduo ficava submetido sem reservas em seus sentimentos, ideias e atos. Por mais imponentes que nos pareçam, os homens de então mal se distinguiam uns dos outros; estavam, como diz Marx, presos ao cordão umbilical da comunidade primitiva (ENGELS, 1982, p. 108-9).

Em suma, a subordinação ao meio natural condiciona a subsunção ao grupo natural (sua fronteira, um poder superior dado pela natureza), na medida em que consanguíneo, e demarca um baixo grau da individuação, da diferenciação recíproca entre os indivíduos, na exata medida em que se submetem sem reservas em seus sentimentos, 
ideias e atos à comunidade - os indivíduos mal se distinguiam uns dos outros. É por isso, em suma, que a sociedade gentílica, apesar de toda sua grandeza, tinha de desaparecer: “o poderio dessas comunidades primitivas não poderia deixar de ser destruído e foi destruído" (ENGELS, 1982, p. 109).

Em outro texto clássico, a "Introdução" de Marx a Para a crítica da economia política, encontramos posição semelhante. Ali se vê a conhecida caracterização do procedimento teórico dos economistas clássicos, a robinsonada - partir do indivíduo isolado: "o caçador e o pescador, individuais e isolados, de que partem Smith e Ricardo, pertencem às pobres ficções das robinsonadas do século XVIII” (MARX, 1982, p. 3). Procedimento metodológico que, para Marx, não pode ser explicado apenas como "uma simples reação contra os excessos de requinte e um retorno mal compreendido a uma vida natural. /.../. Essa é a aparência puramente estética, das pequenas e grandes robinsonadas" (MARX, 1982, p. 3). Com efeito, fiel à noção de crítica ontológica, identifica a raiz dessas posições na própria sociabilidade burguesa, isto é, como uma "antecipação da 'sociedade', que se preparava desde o século XVI, e no século XVIII deu larguíssimos passos em direção à sua maturidade" (MARX, 1982, p. 3). A sociedade moderna é a sociedade de indivíduos, a sociedade na qual se rompem os liames espontâneos que atrelavam os homens uns aos outros ${ }^{211}$, isto é, "nessa sociedade da livre concorrência, o indivíduo aparece desprendido dos laços naturais que, em épocas históricas remotas, fizeram dele um acessório de um conglomerado humano limitado e determinado" (MARX, 1982, p. 3).

Engels considerava o indígena como limitado por sua fronteira, sua tribo - o que Marx caracteriza como o fato de o indivíduo aparecer como um acessório da comunidade - um conglomerado humano limitado e determinado. E, efetivamente, quanto mais se remonta à história, mais o indivíduo aparece subordinado à comunidade natural à qual pertence, expressão de sua subjugação ao meio natural: "quanto mais se recua na História, mais dependente aparece o indivíduo, e portanto, também o indivíduo produtor, e mais amplo é o conjunto a que pertence" (MARX, 1982, p. 4). Ainda que este conjunto assuma formas diferenciadas ao longo da história: "De início, este aparece de um modo ainda

\footnotetext{
${ }^{211}$ Podemos, para esclarecimento, seguir Lefebvre (1972, p. 94): “A natureza não se contenta em fornecer materiais que a atividade produtiva colhe, isola, transforma. A comunidade sai da natureza, como comunidade de sangue, de costumes e de língua. Esta primeira condição da apropriação social das condições objetivas, a comunidade, surge da natureza das maneiras mais diferentes, pois a própria natureza é extraordinariamente diversa".
} 
muito natural, numa família e numa tribo, que é a família ampliada; mais tarde, nas diversas formas de comunidade resultantes do antagonismo e da fusão das tribos" (MARX, 1982, p. 4).

A individuação é, assim, um produto da história - "produto, por um lado, da decomposição das formas feudais de sociedade e, por outro, das novas forças de produção que se desenvolvem a partir do século XV" (MARX, 1982, p. 3). Caracterizar, então, as

formas feudais de sociedade - que, no caso, não dizem respeito tão somente ao feudalismo europeu ocidental - e as forças de produção desenvolvidas a partir do século XVI, em suas dimensões geográficas, é o passo que buscamos nesse capítulo final de nossa dissertação. Para tanto, comprovada a permanência dessa compreensão em outras paragens da obra marxiana e marxista, podemos retomar $A$ ideologia alemã e, também, introduzir os Grundrisse, em especial a passagem que ficou conhecida como Formen. Ademais, trata-se de uma questão abordada, em diferentes níveis e dimensões, por Massimo Quaini, em Marxismo e geografia, e Henri Lefebvre, O pensamento marxista e a cidade - ambas pouco aprofundadas na tradição geográfica. Com elas também, portanto, buscamos uma interlocução mais direta.

\subsection{CONFIGURAÇÕES TERRITORIAIS DA GEOGRAFIA RURAL E INDIVIDUAÇÃO RESTRINGIDA NAS FORMAÇÕES COMUNITÁRIAS}

O reconhecimento da existência de, pelo menos, dois momentos do processo histórico concernente ao desenvolvimento e formação de indivíduos é explícito n'A ideologia alema $\tilde{a}^{212}$, bem como da relação desses momentos com as capacidades humanas de apropriação e produção da natureza - exterior e a dos próprios homens. Por exemplo, em fragmento incompleto (não roído) da obra, Marx e Engels diferenciam duas situações demarcadas pela "diferença entre os instrumentos de produção naturais e aqueles criados pela civilização". No primeiro caso, temos como características a "localidade" (contraposta à "divisão do trabalho e um extenso intercâmbio") e a predominância do “campo (a água etc.) [que] pode ser considerado como instrumento de produção natural".

\footnotetext{
${ }^{212}$ No capítulo 2 mostramos como essa leitura aparecia nos artigos publicados nos Anais franco-alemães.
} 
Tal caracterização inicial nos permite reconhecer a predominância de um complexo geográfico marcadamente rural: "o campo é o centro geográfico desta civilização e é o modo de vida rural que marca a totalidade do complexo" (MARTINS, 2014, p. 22). O uso do termo civilização, nesta passagem, não contraria o que aqui se pretende desenvolver, quando reconhecemos a existência de diferentes formações sociais marcadas por esta geografia rural nucleada pelo campo e pela localidade, isto é, por relações sociais que se dão em âmbito espacial restrito.

Associado a este reconhecimento inicial por parte de Marx e Engels, temos todo o desenvolvimento desses pressupostos no ponto de vista dos indivíduos, isto é, estes “encontram-se como instrumentos de produção ao lado do instrumento de produção dado" (ou seja, não produzido pelos homens), "são subsumidos à natureza", ou melhor, "a troca é fundamentalmente entre os homens e a natureza, uma troca na qual o trabalho daqueles é trocado pelos produtos desta última" e ainda não se põe a divisão de trabalho - nem entre trabalho material e espiritual ("é suficiente o entendimento médio dos homens, a atividade corporal e a espiritual ainda não estão de forma alguma separadas"), nem a divisão de tarefas ("existe a pequena indústria, mas subsumida à utilização do instrumento de produção natural e, por isso, sem distribuição entre diferentes indivíduos") (MARX; ENGELS, 2007, p. 51). Intimamente coligado à percepção das características mais relacionadas à produção material, portanto, Marx e Engels intercalam considerações a respeito dos modos de ser dos indivíduos; e ainda desenvolvem: tal modo de vida "pressupõe que os indivíduos estão unidos por um laço qualquer, seja ele a família, a tribo, o próprio solo etc.”. Como vimos na seção anterior, a subsunção ao meio geográfico ainda marcadamente regido por forças e ciclos naturais conforma uma subsunção ao grupo natural, no sentido, essencialmente, de espontâneo, dado pela linhagem. E, ainda, mesmo que já existam relações de classe (as referências, portanto, não são apenas às comunidades primitivas), "a dominação dos proprietários sobre os não-proprietários pode se basear em relações pessoais, numa forma de comunidade" (MARX; ENGELS, 2007, p. 51).

Curioso perceber que toda esta riqueza encerra-se em um parágrafo. Caráter sintético que, como reconheceu Engels em outro momento, em realidade expressava os limites da compreensão da história dos próprios autores. De todo modo, ainda que certos 
equívocos venham a ser corrigidos ${ }^{213}$, o essencial da leitura se mantém: "a unidade do ser vivo e ativo com as condições naturais, inorgânicas" (MARX, 2011, p. 401), isto é, "as condições originais da produção /.../, originariamente, não podem ser elas próprias produzidas - não podem ser resultados da produção” (MARX, 2011, p. 401). Esta situação se refere a todas as "formas em que a propriedade da terra e a agricultura constituem a base da ordem econômica e, por conseguinte, em que a produção de valores de uso é a finalidade econômica" (MARX, 2011, p. 397). E estas condições originais são duas: a comunidade humana e a terra, isto é, nestas formas sociais o homem

se acha frente a si mesmo na condição de membro de uma família, clã, tribus etc. - que assumem, em seguida, pela miscigenação com e oposição a outros, formas históricas diferenciadas; e, nessa condição de membro, ele se relaciona com uma natureza determinada (digamos, ainda nesse ponto, a terra, o território) como sendo sua própria existência inorgânica, como condição de sua produção e reprodução (MARX, 2011, p. 401, grifo nosso).

Grifamos, na citação acima, a ideia de condição, principalmente na medida em que é posta ainda de maneira natural, e como Marx igualmente ressalta: "as condições originais aparecem como pressupostos naturais, condições naturais de existência do produtor, exatamente como o seu corpo vivo aparece como o pressuposto de si mesmo, uma que, pois mais que ele o reproduz e o desenvolva, não é posto por ele mesmo (MARX, 2011, p. 401). E, em outro momento, destaca o caráter da propriedade nessas formações, novamente reconhecendo o duplo caráter dos pressupostos naturais - a comunidade e a terra, ou melhor, o território - no que, inclusive, especifica este como decorrente da apropriação (isto é, a transformação da terra em corpo inorgânico) e da própria terra como meio fundamental do trabalho. Ou seja,

propriedade significa, portanto, pertencer a uma tribo (comunidade) (ter
existência subjetiva-objetiva dentro dela) e, por mediação do comportamento
dessa comunidade em relação ao território, à terra como seu corpo inorgânico,
[significa também] comportamento do indivíduo em relação ao território, à
condição originária exterior de produção porque a terra é, a um só tempo,
matéria-prima, instrumento e fruto - como pressupostos pertencentes à sua
individualidade; como modos de existência da individualidade (MARX, 2011,
p. 403-4).

Não está ausente, assim, um ambiente construído pelos homens, como vimos nucleado pelo habitat, pelas construções associadas à moradia e ao abrigo dos homens, mas é evidente a definição da naturalidade dessas formações, na medida em que, essencialmente, a comunidade representa os liames espontâneos formados entre os

213 Por exemplo, em $A$ ideologia alemã, Marx e Engels referem-se à existência da escravidão nas comunidades primitivas - fato que será negado por diversas pesquisas antropológicas posteriores, como reconhecido pelos próprios autores tanto nos Grundrisse como n'A origem da família, da propriedade privada e do estado. 
indivíduos - de sangue, costumes e língua. "Esta primeira condição da apropriação social das condições objetivas, a comunidade, surge da natureza das maneiras mais diferentes, pois a própria natureza é extraordinariamente diversa" (LEFEBVRE, 1972, p. 94). Dada esta naturalidade, ou seja, a emergência da comunidade da própria natureza, espontânea, destaque-se a unidade ecológico-territorial que aí se conforma, a unidade entre o indivíduo e as condições de sua existência (a comunidade e o território); daí Milton Santos (2008, p. 236) referir-se, ao abordar o meio natural, à uma harmonia socioespacial: "a sociedade local era, ao mesmo tempo, criadora das técnicas utilizadas, comandante dos tempos sociais e dos limites de sua utilização". E, por sua vez o uso marxiano da categoria de território é consciente e explicitado, enquanto relacionado à apropriação de uma parcela da superfície terrestre pelo grupo natural: “é somente pela caça das tribos que uma região da terra se converte em um território de caça; é somente pelo cultivo da terra que o território é posto como o prolongamento do corpo do indivíduo" (MARX, 2011, p. 405). Temos, assim, um indivíduo uno com as condições de sua existência, "ele próprio não é só o corpo orgânico, mas essa natureza inorgânica como sujeito" (MARX, 2011, p. 400). E se destaque a referência à inorgânico em sentido distinto do normalmente posto por Lukács (isto é, como uma das esferas da natureza), mas como aquilo que, sendo sua extensão, não compõe o próprio corpo, estritamente, do indivíduo.

Nesse sentido, podemos referirmo-nos a outra categoria geográfica fundamental - a do habitat, conforme delineamos no capítulo precedente. Embora a moradia sempre ocupe um papel de destaque no ambiente construído pelos homens, ela não se encontra (ao menos não para os produtores diretos, visto que os proprietários dos meios de produção, por definição, estão afastados do trabalho material, no caso das formações em que já se pôs a divisão do trabalho e a propriedade privada), no complexo geográfico rural, destacada dos demais lugares associados à produção propriamente dita, conformando efetiva e materialmente a unidade supracitada:

Edificando um abrigo para sua família e para si próprio, ele constrói ao mesmo tempo edifícios que lhe sirvam ao trabalho: para guardar suas colheitas, instrumentos de trabalho, animais, viaturas etc. Assim, a casa não é unicamente essas quatro paredes e esse teto sob os quais dorme a família: é todo um conjunto de construções que constituem, nas mãos dos homens, um verdadeiro instrumento de trabalho agrícola e cujo arranjo se concebe em função desse trabalho. A casa participa estreitamente, pois, do gênero de vida (MONBEIG ${ }^{214}$ apud DANTAS, 2009, p. 12).

\footnotetext{
214 Pierre MONBEIG, "Notas relativas à evolução das paisagens rurais de São Paulo", Boletim Geográfico,
} n. $16,1944$. 
De outro lado, a referência marxiana à natureza como o corpo inorgânico do homem, associada às reflexões apresentadas no capítulo anterior sobre o espaço, a partir de Lefebvre, isto é, todo corpo produz e contém espaço, na medida em que se relaciona com outros seres e, assim, estabelece uma inteligência do corpo, que pode ser desdobrada, no âmbito do ser social, no sentido de uma consciência espacial, em outros termos, se compreendemos que todo indivíduo e agrupamento humano engendra, na sua própria prática, ideias acerca da ordem tópica na qual se insere, podemos identificar alguns elementos, digamos, da consciência espacial pré-capitalista. Que já havia sido demarcada, no essencial e exatamente nesse sentido, por Lacoste, quando abordava as "representações de espaços" associadas às práticas sociais "na época em que a maioria dos homens vivia ainda para o essencial, no quadro da auto-subsistência aldeã" (LACOSTE, 2007, p. 43), isto é, as formações sociais pré-capitalistas que aqui abordamos. Nesse caso, "a quase totalidade de suas práticas se inscrevia, para cada um deles, no quadro de um único espaço, relativamente limitado: o 'terroir' da aldeia e, na periferia, os territórios que relevam das aldeias vizinhas" (LACOSTE, 2007, p. 43). Este território limitado "eles conheciam bem concretamente, por experiência pessoal" (LACOSTE, 2007, p. 44).

Aliás, a remissão à consciência espacial de um espaço único e limitado permite retomar a discussão de que a unidade referida não possui um caráter tão somente positivo. Ao contrário, termina por estabelecer a condição, na medida em que é posta espontaneamente, estabelecendo-se uma contradição insolúvel destas formas sociais, já apontada por Engels no início deste capítulo: o seu próprio funcionamento às condenam ao desaparecimento. Isto porque na medida em que a comunidade e a terra se põem enquanto condições, pressupostos naturais, a própria ação dos indivíduos é orientada para a reprodução dessas condições, ou seja, sua manutenção tal como espontaneamente postas, mas ao simplesmente se reproduzirem e, por exemplo, ampliarem o contingente populacional, os homens terminar por atentar, inconscientemente, contra os objetivos postos. Isto é, como já citamos, a finalidade da produção é a produção de valores de uso, nas palavras de Marx:

A finalidade de todas essas comunidades é a conservação; i.e., a reprodução dos indivíduos que a constituem como proprietários, i.e., no mesmo modo de existência objetivo que constitui ao mesmo tempo o comportamento dos membros uns em relação aos outros e, por isso, a própria comunidade. Mas essa reprodução é ao mesmo tempo necessariamente produção nova e destruição da forma antiga (MARX, 2011, p. 405, grifo do autor). 
Assim, a unidade entre indivíduo e suas condições de existência, na medida em que estas não resultam de sua ação, configuram limites objetivos ao indivíduo: "a dupla limitação é o elemento definidor da própria individualidade: do indivíduo por seus liames com os demais, que fazem dele mera unidade dentro do todo, e das potências e formas de apropriação de mundo dos indivíduos como propriedade da comunidade" (ALVES, 2001, p. 265). No interior de todas as transformações, como veremos a seguir, que perpassam as distintas formações comunitárias, este pressuposto natural, em uma palavra, seu caráter rural, permite referir a uma individualidade restringida.

Em outros termos, e explicitando a fim de que a posição marxiana não seja confundida com qualquer tipo de evolucionismo linear e teleológico (muito menos eurocêntrico), se "em todas essas formas, o fundamento do desenvolvimento é a reprodução das relações pressupostas do indivíduo singular à sua comunidade" (MARX, 2011, p. 398), relações que, de origem natural ou histórica, tornam-se tradicionais, tratase da reprodução de "uma existência objetiva, determinada, predeterminada para o indivíduo, no comportamento seja com as condições do trabalho, seja com seus companheiros de trabalho, companheiros da tribo etc." (MARX, 2011, p. 399). Configura-se, assim, explicitamente, uma individualidade restringida, por sua condição social estar posta tradicionalmente e, nas formações comunitárias, o indivíduo não se separar desta. Como, aliás, já reconheciam n’A ideologia alemã: nessas formações, “o nobre continua sempre um nobre e um roturier continua um roturier, abstração feita de suas demais relações; é uma qualidade inseparável de sua individualidade" (MARX, ENGELS, 2007, p. 65). Como aparece também nos Manuscritos econômico-filosóficos e é sintetizado por Lefebvre (1972, p. 32), no que bem caracteriza o tipo de individualidade aqui descrito:

A propriedade feudal comporta uma relação entre a terra e os seres humanos. O senhor toma o nome da terra e esta personaliza-se com ele. O servo é acessório da terra, mas o herdeiro (o filho mais velho do senhor) também pertence à terra, pátria local, singularmente acanhada, que é o suporte da família senhorial, da casa senhorial, da linhagem, da vassalagem e da sua história.

Enfim, em todas as formações comunitárias o campo constitui o fundamento econômico essencial - inserindo-as, dessa forma, no que caracterizamos como complexo geográfico rural, em que os ritmos e os ciclos são ainda de caráter marcadamente naturais (ainda que sua marcação em calendários, por exemplo, seja, sempre, um fato humano) e o ambiente construído traga a marca da localidade, dentre outras características. De outro 
lado, tais formações diferenciam-se, segundo Marx, essencialmente, em três grandes tipos - oriental ou asiática, antiga ou greco-romana e germânico ${ }^{215}$ - em especial "no desenvolvimento ou não de uma formatação efetivamente social, mediada e impulsionada por um intercâmbio variado e crescente entre os seus membros" (ALVES, 2001, p. 266). Tal formatação efetivamente social configura distintos relacionamentos com o território, enquanto laboratório natural, materializados, essencialmente, nas características das cidades que então se desenvolvem: "a cidade, substituindo a natureza 'objetiva' como condição da apropriação, impôs-se como laboratório" (LEFEBVRE, 1972, p. 94). A fim de evitar mal entendidos, sigamos a caracterização completa apresentada pelo filósofo francês:

\begin{abstract}
Do mesmo modo que a terra, a cidade representa uma força produtiva (mas não um meio de produção ou um instrumento). Permitindo a reunião dos trabalhadores e dos trabalhos, dos conhecimentos e das técnicas, dos próprios meios de produção, intervém ativamente no crescimento e no desenvolvimento e pode portanto contrariá-los (LEFEBVRE, 1972, p. 94).
\end{abstract}

O reconhecimento da intervenção ativa da cidade nos permite compreender uma determinação geográfica - que não pode, em hipótese alguma, ser confundida com qualquer tipo de determinismo, mas subentende, tão somente, o reconhecimento do complexo geográfico como um componente das múltiplas determinações que configuram o ser social. Marx e Engels referiram-se à temática explicitando diretamente sua influência no desenvolvimento dos indivíduos. Tratamos da progressiva formatação verdadeiramente social, mediada e impulsionada por um intercâmbio variado $e$ crescente, no qual, por sua vez, as configurações territoriais exercem papel decisivo, potencializando ou constrangendo o intercâmbio entre os homens.

Ou seja, a atividade objetiva dos homens projeta no território a divisão social do trabalho - "a maior divisão entre trabalho material e espiritual é a separação entre cidade e campo" (MARX; ENGELS, 2007, p. 52) - inserindo um novo elemento na formação comunitária advinda das sociedades estritamente tribais e constituindo uma mediação fundamental na determinação social das individualidades. Com efeito, se "a divisão do trabalho dá origem a camadas sociais distintas, de modo que as existências passam a ser cristalizadas em campos restritos da atividade e do inter-relacionamento social" (TEIXEIRA, 1999, p. 189), a oposição entre campo e cidade "é a expressão mais crassa da subsunção do indivíduo à divisão do trabalho, a uma atividade determinada, a ele

\footnotetext{
${ }^{215}$ A formação feudal, de características particulares, em especial no tocante à relação entre cidade e campo, aparece essencialmente como a fusão entre as duas últimas, sob hegemonia da germânica.
} 
imposta - uma subsunção que transforma uns em limitados animais urbanos, outros em limitados animais rurais e que diariamente reproduz a oposição entre os interesses de ambos" (MARX; ENGELS, 2007, p. 52). Nesse sentido, adicionam distintos limites objetivos ao intercâmbio social, configurando efetivamente uma determinação geográfica $^{216}$ : “a cidade é, de pronto, o fato da concentração da população, dos instrumentos de produção, do capital, das fruições, das necessidades, enquanto o campo evidencia o fato contrário, a saber, o isolamento e a solidão" (MARX; ENGELS, 2007, p. 52). Vale demarcar que, para o caso das três principais formas - oriental, antiga e germânica - a cidade, quando se desenvolve, é, essencialmente, a cidade política - "com a cidade surge, ao mesmo tempo, a necessidade da administração, da polícia, dos impostos etc., em uma palavra, a necessidade da organização comunitária e, desse modo, da política em geral" (MARX; ENGELS, 2007, p. 52).

Também Quaini explicita o fato de que o entendimento marxiano da centralidade da propriedade fundiária ("como base e resultado da comunidade") e da "unidade natural do trabalho com seus pressupostos materiais /.../ nos explica também porque, em sua análise, Marx se delonga não somente sobre as formas de propriedade, mas também sobre as estruturas territoriais da organização social e econômica da comunidade" (QUAINI, 1979, p. 89). Tanto Quaini ${ }^{217}$ quanto Henri Lefebvre ${ }^{218}$ sumariam a abordagem marxiana com destaque para as configurações territoriais e seus papéis. O resultado final, com efeito, é o mesmo. Quaini é sintético ao afirmar que "emerge desta caracterização a centralidade da relação cidade-campo", que se dá ainda de uma forma particular, sem contradições: "embora a relação cidade-campo se apresente bem diferenciada nas três formas, no fundo, em todas está ainda ausente o contraste entre cidade e campo, visto por Marx como uma necessária premissa da 'história moderna"” (QUAINI, 1979, p. 92). Lefebvre (1972, p. 111), por sua vez:

nestas páginas dos Grundrisse, não assistimos à construção abstracta de entidades, os 'modos de produção', mas à análise de um devir, à gênese de um processo dialético que abarca toda a extensão deste devir, a partir de uma relação conflitual, a da cidade e do campo, virtualmente presente desde as origens, mas que se atualiza, se metamorfoseia e gera formas novas.

\footnotetext{
${ }^{216}$ Mais uma vez grife-se, enquanto uma mediação da determinação social, visto que o geográfico, como já pontuamos com Demangeon, indica a ação humana. Em outros termos, refere-se aqui a uma específica determinação objetiva.

${ }^{217}$ Cf. QUAINI, 1979, p.85-101.

${ }^{218}$ Cf. LEFEBVRE, 1972, pp. 77-120.
} 
Com base na posição e papel cumprido pelas cidades (inclusive na sua ausência), podemos acompanhar a síntese de Quaini (1979, p. 92), quanto às três principais formas da comunidade:

\begin{abstract}
- na forma oriental a totalidade econômica é dada pela aldeia auto-suficiente, mantendo-se a cidade como uma 'superposição' sobre a estrutura econômica propriamente dita;

- na forma greco-romana a totalidade econômica é dada pela cidade, que contudo assume mais uma função estatal do que econômica, diferencia em relação ao campo;

- na forma germânica, a totalidade econômica é dada pela moradia rural esparsa no campo e pela família camponesa, estando ausente a cidade.
\end{abstract}

A passagem em que o próprio Marx (2011, p. 395) sintetiza as diferenças é conhecida, e, ainda assim, merece ser retomada em sua integralidade:

\begin{abstract}
A história da Antiguidade clássica é [a] história da cidade, mas de cidades fundadas na propriedade de terra e na agricultura; a história asiática é uma espécie de unidade indiferente de cidade e campo (nesse caso, as cidades realmente grandes têm de ser consideradas como acampamentos principescos); a Idade Média (época germânica) parte da terra como sede da história, cujo desenvolvimento posterior se desenrola então como oposição entre cidade e campo; a [história] moderna é a urbanização do campo, não a ruralização da cidade, como entre os antigos.
\end{abstract}

Vejamos, ainda, algumas particularidades dessas formações. O destaque marxiano, como reconhecem Quaini e Lefebvre, recai efetivamente sobre as distintas formas de interação entre cidade e campo, que representam, em realidade, a materialização (e o consequente condicionamento recíproco, dialético) das diferentes formas de comunidade e, por conseguinte, das individualidades. No caso da primeira, temos "como fundamento de fato essa propriedade tribal ou comunitária, gerada na maioria das vezes por meio de uma combinação de manufatura e agricultura no interior da pequena comunidade, que dessa forma se torna autossuficiente e contém em si mesma todas as condições da reprodução e mais-produção" (MARX, 2011, p. 389). Sendo que uma parte dessa produção, do excedente, "pertence à coletividade mais elevada que existe como pessoa" (MARX, 2011, p. 389). Tal forma de relação da comunidade com a natureza assume variadas configurações, em muito dependente das próprias condições geográficas, mas o resultado é que, de um lado, "a propriedade só existe como propriedade comunitária, o membro individual enquanto tal é somente possuidor, hereditário ou não, de uma parte particular" (MARX, 2011, p. 393) e, de outro, "as cidades propriamente ditas formaram-se, ao lado desses povoados, apenas em pontos essencialmente favoráveis ao comércio exterior; ou onde o chefe de Estado e seus sátrapas 
trocavam sua renda (produto excedente) por trabalho, gastando-a como fundo de trabalho" (MARX, 2011, p. 390).

Outra é a situação daquelas formações em que a comunidade "não presume a terra como base, mas a cidade como a sede já constituída de pessoas do campo. (Proprietários de terra.) O campo aparece como território da cidade; e não o povoado, como simples apêndice do campo" (MARX, 2011, p. 390). Esta é a forma antiga, ou greco-romano, da comunidade, na qual "a cidade antiga perdeu a imediatidade e ganhou o caráter de mediação que marcará o seu destino" (LEFEBVRE, 1972, p. 97). A cidade, assim, representa uma outra formatação do intercâmbio social, isto é, "se eleva como uma alteração de raiz na forma do ser comunal, que afirma virtualmente o intercâmbio e não o isolamento como sustentáculo da vida em comum, a comunhão e a troca, limitadas à comunidade, evidentemente, como metas e pressupostos da interatividade" (ALVES, 2001, p. 266).

Aqui, como ressalta Marx, já se diferencia a propriedade comunitária, enquanto propriedade do Estado, da cidade, e a propriedade privada individual (de todo modo, à qual o indivíduo acede apenas por intermédio da vida comunitária). E, "com a reunião na cidade, a comunidade enquanto tal possui uma existência econômica; a simples existência da cidade enquanto tal é diferente da simples pluralidade de casas independentes. O todo não consiste aqui de suas partes. É um tipo de organismo autônomo" (MARX, 2011, p. 395). Assim, a simples existência cidade é elemento determinante, na medida em que exterioriza, em relação aos indivíduos, seus vínculos comunitários: "tal concentração simples - da cidade como centro da vida rural, como domicílio dos rurais, bem como centro do comando de guerra - faz com que a comunidade enquanto tal tenha uma existência externa, distinta da existência do indivíduo singular" (MARX, 2011, p. 395).

Auxilia a demarcar essa especificidade, e a centralidade da cidade, a contraposição em relação à terceira forma da comunidade, a germânica, na qual "a comunidade não existe de fato como Estado, sistema estatal, como entre os antigos, porque ela não existe como cidade" (MARX, 2011, p. 395). Isto é, na comunidade germânica, como Marx sistematizara momentos atrás, temos a terra como sede da história e "os chefes de família individuais se fixam nas matas, separados uns dos outros por longas distâncias" (MARX, 2011, p. 395), de modo que embora a comunidade esteja "posta na descendência, na língua, no passado e história comuns etc.”, a própria dispersão das famílias faz com que ela apenas se efetive, “desde logo externamente considerada, pela reunião periódica dos 
membros da comunidade" (MARX, 2011, p. 395) ${ }^{219}$. Nesse caso, enfim, “a totalidade econômica, no fundo, está contida em cada casa singular, que constitui por si mesma um centro autônomo da produção (manufatura puramente como trabalho doméstico acessório das mulheres etc.)" (MARX, 2011, p. 396).

Certo destaque os autores aqui seguidos conferem, ainda, ao feudalismo, resultante da fusão dos resquícios da comunidade antiga com a germânica, sob a hegemonia desta última, configurando uma geografia com pleno domínio do campo, isto é, temos uma ruralização da sociedade, como afirmara Marx, parte da terra como sede da história. Na mesma passagem, acima reproduzida, o filósofo alemão reconhece que seu "desenvolvimento posterior se desenrola então como oposição entre cidade e campo" (MARX, 2011, p. 395). Lefebvre (1972, p. 101) destaca esse aspecto ao ressaltar que "o desenvolvimento só atingiu toda a sua amplitude e só abarcou todo o campo do possível onde se desenrolou o aspecto conflitual da relação cidade-campo e o conflito atingiu o paroxismo". Tal aspecto, com efeito, não se põe nas cidades do oriente - "aí não houve conflito, e por isso foram em vão toda sua grandeza, todo o esplendor, todo o poder" (LEFEBVRE, 1972, p. 101). Também não atingiu o nível do conflito a cidade antiga: "dominando politicamente o campo, era o campo que a dominava economicamente. $\mathrm{O}$ conflito não atingia seu termo e, por isso, acarretava a decomposição" (LEFEBVRE, 1972, p. 101). A única que não resulta, simplesmente, em sua decomposição, mas em algo novo, é a cidade medieva, "mediante luta encarniçada, que foi já uma luta de classes" (LEFEBVRE, 1972, p. 101) na medida em que as forças originadas do campo buscavam dominá-la e submetê-la. Dessas transformações, trataremos mais adiante.

Caracterizadas, ainda que de maneira aproximada ${ }^{220}$, as diferentes formações comunitárias, e a centralidade da relação cidade-campo, podemos retomar alguns elementos quanto à questão da individuação. Em primeiro lugar perceba-se a constante referência marxiana a esta questão - parte sempre dos indivíduos humanos e, portanto, da relação destes com as condições objetivas de sua existência: "a apropriação efetiva não acontece primeiro na relação imaginada, mas na relação ativa, real, com essas condições

\footnotetext{
${ }^{219}$ Em passagem na sequência, Marx (2011, p. 397) repõe esta caracterização: “a comunidade em sim, por um lado, como comunidade na língua, no sangue, etc., é pressuposta ao proprietário individual; mas, por outro lado, como existência ela só existe em sua assembleia efetiva para fins comunitários e, na medida em que ela tem uma existência econômica particular nas áreas de caça, pastagem, etc. de uso comum, ela é utilizada por cada proprietário individual enquanto tal, e não como representante do Estado (como em Roma)".

${ }^{220}$ Grife-se que a própria caracterização marxiana é igualmente aproximada, na medida em que objetiva a compreensão da emergência do capital e do trabalho "livre" e assalariado.
} 
- o seu pôr efetivo como as condições de sua atividade subjetiva" (MARX, 2011, p. 404). E esta atividade subjetiva, para Marx, mostra-se condicionada e limitada pelas condições que se põem como pressupostos dados, que devem ser reproduzidos como tais. Nas formações comunitárias, assim, “os indivíduos podem parecer importantes. Todavia, não se pode pensar aqui em um desenvolvimento livre e pleno nem do indivíduo nem da sociedade, uma vez que esse desenvolvimento está em contradição com a relação original” (MARX, 2011, p. 339). Isto é, como vimos, a restrição das individualidades se explicita nas próprias capacidades dos indivíduos - tanto nas suas condições efetivas, ainda subordinadas ao meio natural, quanto no sentido de que seu desenvolvimento termina por romper o pressuposto dado:

Todas as formas (mais ou menos natural e espontaneamente originadas, mas, ao mesmo tempo, todas também resultado do processo histórico) em que a comunidade supõe os sujeitos em uma unidade objetiva determinada com suas condições de produção, ou em que uma existência subjetiva determinada supõe as próprias comunidades como condições de produção, tais formas correspondem necessariamente só a um desenvolvimento limitado, e limitado por princípio, das forças produtivas (MARX, 2011, p. 407).

Assim, o desenvolvimento histórico é, mais uma vez, caracterizado como o desenvolvimento das forças dos próprios indivíduos: "No próprio ato da reprodução não se alteram apenas as condições objetivas, por exemplo, a vila se torna cidade, o agreste, campo desmatado etc., mas os produtores se modificam, extraindo de si mesmos novas qualidades, se remodelando, formando novas forças e novas concepções, novos meios de comunidade, novas necessidades e nova linguagem" (MARX, 2011, p. 405). E, também, como o afastamento progressivo dos homens de seu laboratório natural, ou seja, o rompimento da dupla unidade aludida - do indivíduo com a comunidade e com o território.

É dentro dessa limitação mais geral que se compreende a avaliação de Marx em relação aos gregos, muitas vezes confundida com um eurocentrismo. Ou seja, enquanto fase condicionada ao desaparecimento pelo próprio desenvolvimento, inexorável e, em certa medida, espontâneo (no sentido de que não se realiza necessariamente com um controle consciente, teleológico) dos próprios homens, de suas forças e capacidades, Marx assinala as formações comunitárias como "a infância história da humanidade" e os gregos como "crianças normais" (MARX, 2011, p. 63-4). Ora, tal caracterização nos parece relacionada ao fato de que a comunidade grega permitiu, por mediação da cidade, da sua simples existência um intercâmbio mais efetivo entre os homens. Ademais, em certa passagem, Marx refere-se à comunidade na forma antiga como o 
universal, que, enquanto tal, é uma unidade existente, tanto em sua representação e na existência da cidade e suas necessidades urbanas [grifo $\mathrm{meu}$ ], em contraste com as necessidades do indivíduo singular, quanto em seu território urbano como sua existência particular, diferentemente da existência econômica particular do membro da comunidade (MARX, 2011, p. 396).

Henri Lefebvre desenvolve, no capítulo "A filosofia e a cidade", do Direito à Cidade, diferentes implicações dessa vivência do universal na cidade quando, por exemplo, reconhece que "a filosofia portanto nasce da cidade, com a divisão do trabalho e suas modalidades múltiplas. Torna-se ela mesma uma atividade própria, especialidade. Entretanto, não cai no parcelário", como aliás comentamos no capítulo anterior, ou seja, "tem por interesse fundamental e por finalidade a Totalidade" (LEFEBVRE, 2001, p. 29). Nesse sentido, a filosofia termina por ser uma espécie de reprodução, no plano espiritual, da própria cidade. Isto é, muito próximo da afirmação de Marx quanto à cidade como o fato da concentração, temos que "a cidade ligada à filosofia reúne portanto pelo e em seu Logos as riquezas do território, as atividades dispersas e as pessoas, a palavra e os escritos (dos quais cada um já pressupõe o recolher e o recolhimento). Ela torna simultâneo aquilo que no campo e segundo a natureza acontece, se divide segundo ciclos e os ritmos" (LEFEBVRE, 2001, p. 30) e, exatamente nesse sentido, "a obra da cidade continua e se concentra na obra dos filósofos, que recolhe as opiniões e os conselhos, as obras diversas, que reflete sobre elas numa simultaneidade, que reúne diante de si as diferenças numa totalidade" (LEFEBVRE, 2001, p. 30).

Em geral se realizando no interior da cidade política, outro interessante ponto que podemos evidenciar é a manifestação objetiva, geográfica, da individualidade restringida na forma do monumento, que abarca e constrange as individualidades: "o espaço monumental oferecia a cada membro de uma sociedade a imagem de seu pertencimento e de sua fisionomia social, espelho coletivo mais 'verdadeiro' que um espelho individualizado" ${ }^{221}$. Com efeito, Marx destaca que a unidade entre indivíduo e as condições objetivas da produção conjuga-se com as relações de dominação e servidão e "a apropriação da vontade alheia é pressuposto da relação de dominação" (MARX, 2011, p. 411) -, isto é, na medida em que se consolidam as classes sociais nas formações comunitárias, em que o trabalhador continua em unidade com as condições de trabalho, a extração do excedente apenas pode realizar-se a partir de mecanismos extraeconômicos. Nesse sentido bem se compreende o sentido do monumento:

${ }^{221}$ Henri LEFEBVRE, “Arquitetônica espacial”, p. 32. 
Desse espaço social, reunindo todos os momentos e conferindo a cada um seu lugar, cada um tinha sua parte e todos a tinham por inteiro, no interior, sem dúvida, de uma Potência e de uma Sabedoria aceitas. O monumento realizava um 'consenso': efetivamente, tornando-o prático e concreto. $\mathrm{O}$ repressivo e o exaltante pouco podiam dele se desembaraçar; mais exatamente, nele o repressivo se metamorfoseava em exaltação ${ }^{222}$.

Tal discussão configura a evidência da ausência de qualquer tipo de economicismo. Em uma palavra, é explícito, resumindo com Lefebvre (1972, p. 115), que “as sociedades históricas tiveram uma base econômica, evidentemente; não há sociedade sem 'produção' no sentido restrito do termo; todavia, nas sociedades do passado as relações sociais mais importantes não eram econômicas”. Ainda o mesmo Lefebvre (1972, p. 115) concretiza: "essas sociedades tiveram uma base econômica, mas as estruturas e superestruturas, embora se não pudessem libertar da base, comportavam um grau de liberdade que desde então desapareceu", no que podemos destacar, ainda mais, a influência do espaço monumental na constituição das individualidades restringidas das formações comunitárias.

De outro lado, a configuração em grande parte monumental do meio urbano, inserido ainda em um todo rural, permite evidenciar um caráter relacionado da cidade nas formações comunitárias: sua função enquanto valor de uso, ou então, como explicita Lefebvre, como obra. Isto é, a cidade é, ela própria, um valor de uso, em especial nas formações antiga e feudal (na qual surge a cidade comercial) - a cidade, concentrando as fruições e enquanto monumento é também "fruída". Tomando como referência a cidade medieval (e, especialmente, as considerações marxianas correspondem a um plano de fundo evidente) o filósofo francês afirma: “a própria cidade é uma obra /.../. O uso principal da cidade, isto é, das ruas e das praças, dos edifícios e dos monumentos, é a Festa (que consome improdutivamente, sem nenhuma outra vantagem além do prazer e do prestígio, enormes riquezas em objetos e em dinheiro" (LEFEBVRE, 2001, p. 115).

\subsection{CAPITAL, GEOGRAFIA URBANA E INDIVIDUALIDADE MODERNA}

O ponto essencial a ser desdobrado nesta seção já foi por nós indicado (desde a Apresentação), e tem por pressuposto a discussão do item anterior na medida em que permite compreender que "o ser humano só se individualiza no processo histórico"

${ }^{222}$ Ibid., p. 32. 
(MARX, 2011, p. 406) longo, complexo e contraditório de sua auto-constituição. O exemplo de Marx é cristalino:

\begin{abstract}
De fato, é fácil imaginar que alguém poderoso, fisicamente superior, após ter primeiramente capturado o animal, em seguida capture pessoas para fazer com que estas capturem animais; em suma, serve-se do ser humano como de uma condição natural já dada para sua reprodução (sendo que o seu próprio trabalho se resume em dominar etc.), como se serviria de qualquer outro ser da natureza. Mas tal opinião é absurda - por mais que seja correta do ponto de vista de um dado sistema tribal ou comunitário -, porque parte do desenvolvimento de seres humanos individualizados (MARX, 2011, p. 406).
\end{abstract}

E, ao contrário, os homens não se apresentam, de início, individualizados. Daí, sempre importante demarcar, falarmos de um processo de individuação, pois o homem "aparece originalmente como um ser genérico, ser tribal, animal gregário" (MARX, 2011, p. 406), no interior de uma comunidade, de relações comunitárias. E, como vimos, "nessa comunidade é pressuposta a existência objetiva do indivíduo singular como proprietário, digamos, por exemplo, como proprietário de terra, mas pressuposta sob certas condições que o acorrentam à comunidade, ou melhor, que constituem um elo em sua corrente" (MARX, 2011, p. 406). De outro lado, também como vimos, é uma necessidade do próprio desenvolvimento histórico que as condições para esta comunidade, naturalmente postas, desapareçam: "o desenvolvimento das forças produtivas as dissolve, e a sua própria dissolução é um desenvolvimento das forças produtivas humanas", isto é, mais tarde “essa própria base ou pressuposto é abolida ou posta como um pressuposto evanescente, que se tornou muito estreito para o desenvolvimento do bando humano progressivo" (MARX, 2011, p. 406).

E, também pretendemos desenvolver aqui, o central papel de uma nova geografia que se constitui, "pois não é evidente que a cidade é simultaneamente local, instrumento e teatro dramático desta gigantesca metamorfose?” (LEFEBVRE, 1972, p. 33). Local, instrumento e teatro dramático do desenvolvimento da sociabilidade moderna e, por conseguinte, da individuação humana. O filósofo francês, com base nos Manuscritos econômico-filosóficos, desdobra tal afirmação, e vale acompanhá-lo enquanto caracterização inicial do processo em curso (e destaque de sua dimensão geográfica).

Nesse sentido, rompendo com qualquer vestígio de visão teleológica da história, Lefebvre (1972, p. 35) destaca que "os elementos da sociedade capitalista chegam na história como exteriores uns aos outros", respondendo por processos diversos, ainda que em certa medida articulados, como veremos, pelo desenvolvimento do comércio. "A sociedade (burguesa) retoma esses elementos, que lhe chegam separadamente; 
desenvolve-os, mistura-os, congrega-os numa unidade: a produção ampliada, o sobretrabalho global, a mais valia à escala de toda a sociedade" (LEFEBVRE, 1972, p. $35)$ - em grande medida já conformando novos tipos de indivíduos. No que Lefebvre (1972, p. 36) conclui, relembrando o prestígio pessoal que detinha o proprietário de terras: “o possuidor do dinheiro, de capitais, de títulos e de letras perdeu esse prestígio e despojou a propriedade de seu valor místico. Onde? Em que contexto? Na vida citadina, medium (meio, modo, mediação, intermediário) da transformação".

Vejamos, então, como a cidade pôde cumprir tal papel e qual o perfil da individualidade urbana que então se constitui. Retornemos a Marx que constantemente ressalta o elemento que contribui grandemente para a constituição dos elementos que serão reunidos na cidade, isto é, a troca como "um meio essencial dessa individuação. Ela torna o sistema gregário supérfluo e o dissolve" (MARX, 2011, p. 406), demarcando a contraditoriedade de um processo que, inerentemente positivo, manifesta-se na forma do individualismo burguês. Trata-se aqui, portanto, de abordar a segunda situação do processo de individuação, aquela dos instrumentos de produção criados pela civilização, que "pressupõe que os indivíduos são independentes uns dos outros e se conservam unidos apenas por meio da troca" (MARX; ENGELS, 2007, p. 51), isto é, por meio do dinheiro, de modo que a dominação dos proprietários "tem de ter assumido uma forma coisificada num terceiro elemento, o dinheiro" (MARX; ENGELS, 2007, p. 51).

Com efeito, é exatamente a ampliação da troca a raiz inicial da profunda reformulação no modo de ser dos homens que marca a emergência da modernidade. Associada ao incremento das capacidades produtivas dos homens, a expansão do comércio resultou na "constituição de novos nexos de dependência entre os indivíduos" (ALVES, 2001, p. 270), não mais marcados pela naturalidade dos pressupostos (comunidade e território), mas representado exatamente pela produção social destes, que passam a materializar-se no dinheiro, no valor em forma pura. Não é nosso objetivo, no momento, retomar a problematização da assim chamada acumulação primitiva do capital, discussão bem consolidada na geografia brasileira e ainda campo de intenso debate historiográfico ${ }^{223}$, mas ressaltar, a partir de sua caracterização sumária por meio da obra marxiana, os traços fundamentais da sociabilidade moderna que desse processo emerge, nucleada progressivamente pela relação capital, e de sua individualidade - e,

\footnotetext{
${ }^{223}$ Recentemente, Vieira (2012) retomou tal problemática, abarcando a concepção marxiana e os debates em diferentes campos teóricos, o marxista e o braudeliano, em espacial.
} 
ainda, no âmbito da relação entre esses pólos do ser social, indivíduo e gênero, demarcar a diferença específica da relação do indivíduo com o meio geográfico.

Nesse sentido, a sociabilidade moderna explicita-se como aquela em que os nexos da interatividade social materializam-se no dinheiro, no valor de troca, portanto: "a base da produção dos indivíduos não reside mais na manutenção da existência comunal como pressuposição principal e essencial, e sim na troca, no intercâmbio social de valores" (ALVES, 2001, p. 270), condição que apenas é possível quando é suprimida a condição de proprietário por parte do trabalhador, isto é, sua unidade com as condições de existência. Marx é assertivo quanto à questão decisiva no tocante à determinação destes novos nexos sociais:

Não é a unidade do ser humano vivo e ativo com as condições naturais, inorgânicas, do seu metabolismo com a natureza e, em consequência, a sua apropriação da natureza que precisa de explicação ou é resultado de um processo histórico, mas a separação entre essas condições inorgânicas da existência humana e essa existência ativa, uma separação que só está posta por completo na relação entre trabalho assalariado e capital (MARX, 2011, p. 401).

É o processo histórico que institui, generalizadamente, a relação entre trabalho assalariado e capital o problema em tela, "um processo histórico que dissolve as diferentes formas em que o trabalhador é proprietário, ou em que o proprietário trabalha" (MARX, 2011, p. 408). Envolve, portanto, em primeiro lugar, a "dissolução do comportamento em relação à terra - território - como condição natural de produção, com a qual ele se relaciona como sua própria existência inorgânica; como o laboratório de suas forças e domínio de sua vontade" (MARX, 2011, p. 408). Em outras palavras, temos o desaparecimento da condição em que o indivíduo tinha no território (condição objetiva fundamental de sua existência) a sua extensão inorgânica, de modo que passamos a encontrar o "trabalhador livre, como capacidade de trabalho sem objetividade, puramente subjetiva” (MARX, 2011, p. 409).

Exerce papel central em todo esse processo, o mostra Marx, o desenvolvimento do comércio e da usura (isto é, das formas ante-diluvianas do capital) e o acúmulo da fortuna em dinheiro - tanto na constituição de fundos livres que possam vir a ser convertidos em capital como na dissolução das relações históricas, fixas, que vinculavam o trabalhador aos meios de produção. Quanto à fortuna em dinheiro, afirma: "ela própria é ao mesmo tempo um dos agentes daquela dissolução, assim como aquela dissolução é a condição de sua transformação em capital” (MARX, 2011, p. 416). Em outras palavras, o dinheiro, de elemento secundário e marginalizado nas formações sociais anteriores, 
passa, progressivamente, a ocupar um papel central e ativo na sociabilidade moderna: "o próprio dinheiro, à medida que exerce um papel ativo na história, só o faz porquanto ele próprio intervém nesse processo como um meio de separação extremamente enérgico e colabora para a produção dos trabalhadores livres espoliados, sem objetivo" (MARX, 2011, p. 417). O que faz o dinheiro é acelerar a dissolução da unidade entre os indivíduos e as condições de sua existência.

Ou seja, e retomando a argumentação d'A ideologia alemã, o desenvolvimento comercial é um pressuposto da formação do capital na sua forma verdadeira - industrial, em várias dimensões. Em primeiro lugar, por exemplo, "o intercâmbio limitado e a fraca ligação das diversas cidades entre si, a escassez da população e a exiguidade das necessidades não permitiam que se instaurasse uma divisão do trabalho mais ampla" (MARX; ENGELS, 2007, p. 54), constituindo assim as bases para a cidade corporativa, tal como se desenvolve, em especial, na Idade Média - com a divisão do trabalho restrita tanto entre as corporações quanto no interior de cada corporação, exigindo, por parte do artesão, o domínio mais amplo do seu ofício. De modo que é com a separação entre produção e comércio, com a constituição de uma classe de comerciantes, que "estava dada a possibilidade de uma ligação comercial para além dos círculos mais próximos" (MARX; ENGELS, 2007, p. 54), condicionada, ainda, a um conjunto variado de determinações, como a existência de meios de comunicação, segurança pública, relações políticas e o próprio desenvolvimento das necessidades nas regiões potencialmente consumidoras.

Enfim,

com o comércio constituído numa classe especial, com a expansão do comércio por meio dos comerciantes para além dos arredores mais próximos da cidade, surgiu prontamente uma ação recíproca entre a produção e o comércio. As cidades estabeleceram ligação umas com as outras, novas ferramentas foram levadas de uma cidade para outra e a separação entre produção e comércio provou rapidamente uma nova divisão da produção entre as diversas cidades, que passaram cada qual a explorar um ramo industrial predominante. A limitação inicial à localidade começou gradualmente a desaparecer (MARX; ENGELS, 2007, p. 54).

Um novo complexo geográfico começa a se estabelecer, com a potencialidade de transfigurar todas as relações postas, em que, para além da relevância, que permanece, da relação entre campo e cidade "onde circulam capitais, mercadorias e, eventualmente, força de trabalho, /.../ agora temos a importância da relação entre cidades. Observamos a emergência da rede de cidades. Desenvolve-se o contexto da geografia regional" (MARTINS, 2014, p. 25-6). Com efeito, na caracterização de Marx e Engels, o destaque 
recai para o papel do comércio na conexão entre os lugares, na superação das barreiras espaciais, da localidade, a permitir um desenvolvimento da produção (com uma geografia em progressiva ampliação escalar). A troca, assim, torna supérflua a condição comunitária, entre outros, num sentido específico: “depende exclusivamente da extensão do comércio se as forças produtivas obtidas numa localidade, sobretudo as invenções, perdem-se ou não para o desenvolvimento posterior" (MARX; ENGELS, 2007, p. 55). Como diríamos hoje, na ampliação dos fluxos materiais e imateriais e na constituição de uma geografia em rede, mediada pelo mercado:

O capitalismo substitui uma organização territorial formada por células (famílias, tribos, comunidades) independentes entre si mas dependentes dos quadros naturais (dos quais deriva a diversidade dos seus produtos) e unificados somente a posteriori pela troca, com uma organização territorial na qual é o mercado que determina a diferença das esferas de produção que as torna originariamente dependentes (QUAINI, 1979, p. 114).

Ou seja, no que se refere ao complexo geográfico, em termos mais amplos, que resulta dessa cabal modificação nos modos de ser do ser social, temos aqui um de seus traços fundamentais: o caráter expansivo, tendencialmente mundial: “o capital, como formação histórica, como modo de produção, como processo constitutivo de um tipo de civiltà, já possuía na percepção de Marx, desde o início /.../ um dinamismo e uma formatação societária dimensionados em escala mundial" (MELLO, 2000, p. 34). Isto é, argumenta Mello, além dos pressupostos acima estabelecidos - a existência de um patrimônio-dinheiro, que possa ser convertido em capital, e de "trabalhadores livres" - a gênese mesma do capitalismo subentende uma nova geografia, em escala ampliada, que, a rigor, não é produto específico do capitalismo industrial, mas outro de seus pressupostos: "a ruptura com os limites locais ou regionais tradicionais do comércio onde as trocas se realizavam unicamente por meio do intercâmbio de excedentes - é condição sine qua non para a afirmação do valor de troca e sua determinação pelo tempo de trabalho abstrato", em uma palavra: "não há capitalismo em escala simplesmente local” (MELLO, 2000, p. 47) 224 .

Encaminhando, vale perceber que, nos Grundrisse, Marx referenda esses aspectos, ressaltando que "no que se refere à formação da fortuna em dinheiro propriamente dita, antes de sua transformação em capital, ela faz parte da pré-história da economia burguesa" (MARX, 2011, p. 419) - advindo especialmente das outras formas

\footnotetext{
${ }^{224}$ Esta dinâmica da geografia urbana e a permanente redefinição das fronteiras se acentua com a globalização, como explícita, por exemplo, MARTINS (2014, p. 26): "é esta geografia urbana que está no coração da redefinição das fronteiras em escala internacional".
} 
de capital, o usurário e o comercial. Nesse sentido, como assinala Quaini, "ele é em grande parte de origem urbana e implica já numa relação de exploração do campo pela cidade" (QUAINI, 1979, p. 112) - contraposição apenas possível no seio das especificidades do feudalismo. De modo que, contribuindo diretamente ou não com a separação entre as condições e as forças de trabalho, "quando essa separação havia atingido certo nível, a fortuna em dinheiro pôde se pôr como intermediária entre as condições objetivas da vida assim liberadas e as forças de trabalho vivas liberadas, mas liberadas também de todo vínculo e obrigação, e com as primeiras, comprar as últimas" (MARX, 2011, p. 418-9). Encontrando, assim, já prontas as condições, o "próprio do capital é unicamente a união das massas de mãos e instrumentos que ele encontra. Ele os aglomera sob seu comando. Essa é sua verdadeira acumulação; a acumulação de trabalhadores, juntamente com seus instrumentos, em certos pontos" (MARX, 2011, p. 417-8, grifo do autor). A apropriação das condições legadas pelos modos de produção anteriores, inclusive, subjaz na definição marxiana da subsunção formal do trabalho ao capital - própria do período manufatureiro (isto é, da própria transição ao capitalismo). O que temos, em grande medida, materializando a transformação em curso, é uma reestruturação espacial das relações de produção:

o comerciante faz trabalhar para ele vários tecelões e fiandeiros que até então exerciam a tecelagem e a fiação como atividades rurais acessórias, e transforma sua atividade acessória em ocupação principal para eles; desse modo, porém, ele se assenhorou deles e os colocou como trabalhadores assalariados sob seu mando. O passo seguinte é deslocá-los para longe de seus lares e reuni-los em uma casa de trabalho (MARX, 2011, p. 420).

Em outros termos, há uma cisão inaudita no próprio habitat, tal como esta categoria foi definida momentos atrás. Agora, no complexo geográfico urbano em formação, temos, expressando a dissolução da unidade do indivíduo com suas condições de existência, a ruptura também da unidade no habitat - propiciando a concentração efetiva daqueles elementos que se referem à produção. No que comparece a outra dimensão fundamental do processo geográfico que conforma o complexo geográfico do capital: a concentração, que encontra sua síntese na urbanização, submetida agora aos ritmos sociais do dinheiro. Isto é, além da ampliação escalar e da conexão entre os lugares inerentes à formação do capital, especificamente quanto às estruturas territoriais, as relações entre cidade e campo são profundamente transformadas, exprimindo a separação do produtor e suas condições de produção. Concretamente, o capital industrial (ainda na forma da manufatura, na qual, como vimos, já se estabelece a separação acima referida, mas na qual este ainda lida com meios de produção legados de outras formações sociais), 
articulando um capital de origem mundial e urbana, instaura-se inicialmente no campo: "a manufatura, em um primeiro momento, não se apodera da assim chamada pequena indústria urbana - mas da indústria rural acessória, fiar e tecer, o trabalho que requer menos habilidade especializada ou formação artística" (MARX, 2011, p. 420). Trata-se, aqui, da dimensão de que o desenvolvimento do capital industrial pressupõe o mercado mundial, pois a manufatura "surge ali onde se produz em massa para a exportação, para o mercado exterior - portanto, tendo como base o comércio marítimo e terrestre em larga escala" (MARX, 2011, p. 420).

O surgimento da manufatura acentua o processo de dissolução das relações historicamente constituídas, e "forma rapidamente um mercado interno ao destruir todas as atividades rurais acessórias, ou seja, fiando e tecendo para todos, vestindo a todos etc." (MARX, 2011, p. 422). Isto é, aquilo que antes era produzido na forma de valores de uso na economia familiar, para consumo próprio, constitui-se agora na forma do valor de troca. De modo que "a dissolução das relações de servidão, bem como o surgimento da manufatura, transformam então, pouco a pouco, todos os ramos de trabalho em ramos explorados pelo capital" (MARX, 2011, p. 421), processo no qual o capital toma de assalto a cidade. Surgida no campo, "lá onde preexistir uma rede de cidades antigas, a indústria toma de assalto. Apodera-se da rede, remaneja-a segundo suas necessidades" (LEFEBVRE, 2006, p. 8-9). Com efeito, na medida em que constitui uma das condições objetivas do trabalho, o meio urbano é igualmente apoderado e assenhorado pelo capital, inclusive por já conter a característica que é aprofundada, como vimos, pelo capital - a concentração. Não por acaso, assim, o processo de separação do trabalhador dos meios de produção expressar-se-á, geograficamente, como vimos, na forma da urbanização do campo, na medida em que, em primeiro lugar, a dinâmica descrita passa a concentrar de forma inaudita homens e condições de trabalho em pontos do globo submetidos a ritmos sociais e, em segundo lugar, estes ritmos se difundem e transformam a própria estrutura rural: "não obstante essa mudança no campo se imponha por último em suas consequência extremas e em sua forma mais pura, é ali onde começa mais cedo" (MARX, 2011, p. 421).

Se, no capítulo anterior, anotamos a consciência geográfica que resultava da unidade entre o "caracol e sua concha" 225 , enquanto uma plena consciência do meio geográfico, ainda predominantemente natural, é evidente que teremos uma profunda

\footnotetext{
${ }^{225}$ Metáfora utilizada por Marx em $O$ capital para referir a unidade do trabalhador com suas condições de existência.
} 
transformação neste âmbito com o novo modo de ser dos indivíduos na modernidade. Mas podemos apenas compreender efetivamente a nova condição, e por conseguinte a nova consciência, ao constatarmos o novo tipo de relação que se estabelece dos indivíduos com as referidas condições. Com efeito, não se trata que

as condições de propriedade anteriores desses indivíduos tenham desaparecido, mas, ao contrário, supõe somente que se alterou a sua utilização, que o seu modo de existência se transformou, que passaram para outras mãos ou, em partes, permaneceram nas mesmas mãos como fundos livres (MARX, 2011, p. 413).

Em uma palavra, trata-se do fato de que as condições de existência converteramse em capital: "o mesmo processo que contrapõe a massa, na qualidade de trabalhadores livres, às condições objetivas de trabalho, também contrapôs essas condições, na qualidade de capital, aos trabalhadores livres" (MARX, 2011, p. 413). Ou seja, fundamental para compreender a nova individualidade que se institui (e sua relação com o meio), ela não apenas está separada das suas condições de existência, mas contraposta a estas, a partir da dissociação "dos elementos até então unidos - em consequência, seu resultado não é que um dos elementos desaparece, mas que cada um deles aparece em uma relação negativa com o outro -, o trabalhador livre (potencialmente), de um lado, o capital (potencialmente), do outro" (MARX, 2011, p. 413).

Uma relação negativa é a que se estabelece entre os indivíduos e as condições de sua existência,

\begin{abstract}
tendo em vista que, nesse processo, o trabalho objetivado é simultaneamente posto como não objetividade do trabalho, como objetivo de uma subjetividade contraposta ao trabalhador, como objetividade de uma subjetividade contraposta ao trabalhador, como propriedade de uma vontade que lhe é estranha, o capital é ao mesmo tempo necessariamente capitalista /.../. No conceito de capital está posto que as condições objetivas do trabalho - e estas são produto dele mesmo - assumem uma personalidade diante do trabalho ou, o que significa a mesma coisa, que elas estão postas como propriedade de uma personalidade estranha ao trabalhador (MARX, 2011, p. 422, os itálicos são de Marx, o sublinhado é nosso).
\end{abstract}

O que se tem, portanto, é uma radicalização do estranhamento. Em primeiro lugar, pois o homem, despido de todas as condições necessárias à sua subsistência, converte-se em "pura subjetividade", em trabalhador, "é o homem totalmente perdido de si" (MARX, 2004, p. 91), apresentando-se agora no mercado tão somente como o portador de uma mercadoria, exatamente a sua pura subjetividade, a fim de obter as demais mercadorias que garantem a sua sobrevivência: "o homem nada mais do que trabalhador e, como trabalhador, suas propriedades humanas o são apenas na medida em que o são para o capital, que lhe é estranho" (MARX, 2004, p. 91). Dimensão que acaba por radicalizar a 
alienação, desenvolvida, como vimos, com o surgimento da propriedade privada e da divisão do trabalho. Na relação capital,

A produção produz o homem não somente como uma mercadoria, a mercadoria humana, o homem na determinação da mercadoria; ela o produz, nesta determinação respectiva, precisamente como um ser desumanizado tanto espiritual quanto corporalmente - imoralidade, deformação, embrutecimento de trabalhadores e capitalistas. Seu produto é a mercadoria consciente-de-si e auto-ativa, ... a mercadoria humana (MARX, 2004, p. 92-3).

Um âmbito dessa desumanização corresponde à sua redução quase à condição animal. Isto é, para a economia nacional, que, como vimos, expressa o ponto de vista desta sociabilidade, "as carências do trabalhador são assim, para ela, apenas a necessidade de conservá-lo durante o trabalho, a fim de que a raça dos trabalhadores, não desapareça" (MARX, 2004, p. 92). Os trabalhadores são reduzidos às necessidades puramente fisiológicas, negando a determinação fundamental do ser social e constituindo "a existência abstrata do homem como um puro homem que trabalha e que, por isso, pode precipitar-se diariamente a seu pleno nada do nada absoluto e, portanto, na sua efetiva não-existência” (MARX, 2004, p. 93). Curiosa caracterização como a efetiva nãoexistência, aquela do puro homem que trabalha, na perspectiva que normalmente é acusada de economicismo (e, como vimos, constantemente o é no seio da ciência geográfica). Em suma, é o modo de ser dos homens no capital que, efetivamente, os reduzem às condições de busca puramente de sua reprodução e sobrevivência, e, assim, reduz o trabalho a meio, "meio para subsistência física do trabalhador" (MARX, 2004, p. 81). Em outros termos:

\footnotetext{
Chega-se, por conseguinte, ao resultado de que o homem (o trabalhador) só se sente como [ser] livre e ativo em suas funções animais, comer beber e procriar, quando muito ainda habitação, adornos etc., e em suas funções humanas só [se sente] como animal. $\mathrm{O}$ animal se torna humano, e o humano, animal.

Comer, beber e procriar etc., são também, é verdade, funções genuína[mente] humanas. Porém na abstração que as separa da esfera restante da atividade humana, e faz delas finalidades últimas e exclusivas, são [funções] animais (MARX, 2004, p. 83, grifo nosso).
}

Novamente, curioso "economicismo" aquele que condena a redução do homem às necessidades fisiológicas, como sua exclusão de verdadeiras funções humanas. Uma primeira dimensão, então, da individualidade moderna, é a sua submissão às necessidades materiais. Elemento que caracteriza, propriamente, a coerção econômica que fundamenta a modernidade. Explicitando como "no capitalismo é a base econômica que comanda. O econômico domina" (LEFEBVRE, 1972, p. 116). Numa palavra, o pretenso economicismo da obra marxiana talvez decorra, em verdade, para além de 
incompreensões ou imputações politicamente orientadas, da sua apreensão da determinação social pelas relações econômicas na efetividade do ser capitalista.

Em outros termos, é a cisão do indivíduo em relação às condições de sua existência que configuram um modo de ser (e estar) que é, ele próprio, e negação do indivíduo humano, da esfera restante da atividade humana, em privilégio de suas necessidades puramente fisiológicas - e, nesse sentido estrito, econômicas. Esta cisão, aliás, é a expressão concreta de uma individualidade que se encontra destacada de todo o gênero humano e na qual se instaura a venalidade absoluta: "o estranhamento do indivíduo ativo para com suas próprias potências é de uma evidência cortante, trazendo à luz o rebaixamento da potência universal de riqueza à forma da mercadoria” (ALVES, 2001, p. 284). Nesse contexto, "as suas potências não existem para si como potências, e sim enquanto modo de ser particular da mercadoria, do valor. Venalidade necessária, pois sem tal transmutação da potência em valor esta não se efetiva" (ALVES, 2001, p. 284$)^{226}$.

Desdobrando esta determinação, temos o indivíduo, na sociabilidade burguesa, essencialmente como portador de mercadoria, como sujeito da troca, isto é, na medida em que separados das condições objetivas que lhes pressupõem, "se encontram determinados deste modo, antes de tudo, como sujeitos da troca. /.../ os indivíduos se afiguram reciprocamente como meros portadores, possuidores, detentores de valor" (ALVES, 2001, p. 270-1), incorporando as determinações gerais da mercadoria, quais sejam, a equivalência e a indiferença. Nos termos lefebvrianos, poder-se-ia dizer que o produto (produção em sentido estrito, de coisas e objetos), progressivamente, hegemoniza e substitui a obra (produção em sentido lado, filosófico, como criação).

Isto é,

uma vez que as mercadorias, como objetivação vital dos indivíduos na forma societária do capital, existem como equivalentes, entes que 'perdem' suas características materiais efetivas a fim de alçar à esfera do intercâmbio social, os sujeitos da atividade e do intercâmbio, os indivíduos reais e concretos, também têm de abandonar sua figura efetiva, tornando-se entidades tão abstratas quanto os valores que portam (ALVES, 2001, p. 274).

Instaurando-se, assim, uma dinâmica absolutamente contraditória, na qual, a sociabilidade que representa, pela primeira vez, um mundo de indivíduos, possibilita a individuação, termina por sua negação efetiva: "a igualdade social, marca distintiva do

${ }^{226}$ Dimensão que, aliás, já se punha nos Manuscritos econômico-filosóficos, na medida em que lá, "a alienação do trabalhador que produz um ser exterior a si não é mais que uma atividade da própria propriedade privada em seu movimento de se autopor: é a alienação da propriedade priva, é venda" (COSTA, 2001, p. 184). 
mundo capital, é aqui captada por Marx como anulação (ideal e prática) da própria individualidade" (ALVES, 2001, p. 275). De modo que, "o que vigora como norma geral da sociabilidade é o confronto de indivíduos indiferentes" (ALVES, 2001, p. 274), na medida em que "não encontramos mais os nexos essenciais, de sangue, de família, da tradição histórica, que ligavam os indivíduos entre si, mas puros liames derivados da lógica do valor" (ALVES, 2001, p. 274).

Desse modo, "como momento determinado do processo de constituição da individualidade humana, a época moderna se caracteriza por uma configuração da atividade social na qual os indivíduos se relacionam com os meios, com o material e com o próprio ato de objetivação sob a égide da exterioridade" (ALVES, 2001, p. 279). Que se manifesta, assim, na forma de uma individualidade cindida - este é seu marco estrutural e central. Relaciona-se com todas as condições de sua existência como com coisas exteriores. Nesse sentido também o meio geográfico não mais compõe o corpo inorgânico da subjetividade, mas um elemento a ela contraposta. Nesse sentido, temos indivíduos arrastados a um mundo, em escalas progressivamente ampliadas, regidos por forças que eles, absolutamente, não controlam e, por vezes, não compreendem - já que marcadas pelo signo da exterioridade. Assim, "as práticas sociais se tornaram mais ou menos confusamente multiescalares" (LACOSTE, 2007, p. 49). Compreende-se a radicalidade de apreensão de Lacoste acerca da miopia e sonambulismo no seio de uma espacialidade tornada diferencial: "se os sonâmbulos se deslocam sem saber por que num lugar que eles conhecem, nós não sabemos onde estamos nos diversos locais onde temos algo a fazer" (LACOSTE, 2007, p. 49).

Com efeito, enquanto na caracterização das formações comunitárias Marx referiase à centralidade da relação dos indivíduos com o território, na abordagem da sociabilidade moderna tais referências rareiam, a ponto de praticamente configurarem uma ausência (o que se encontra é a abordagem mais geral das condições de existência). Tal não se deve, a nosso ver, por qualquer "cegueira” de Marx em relação ao "espaço", como afirmam alguns geógrafos. Mas ao fato de que, efetivamente, as relações entre os homens passam a ser determinadas muito mais por uma abstração - o dinheiro, objetivamente fundada nas relações de troca, e os homens não estão mais presos a uma determinada condição ou outra relação específica - de sangue ou com a terra.

Ademais, o que pode ser visto como uma relativa pouca atenção de Marx aos problemas especificamente geográficos no ambiente urbano, embora nunca perca de vista 
a questão das relações entre campo e cidade e entre indivíduos e território no contexto da geografia rural, pode ser explicado pela contextualização de sua obra. Com efeito, a "estratégia de classe que visa ao remanejamento da cidade, sem relação com sua realidade, com sua vida própria” (LEFEBVRE, 2006, p. 15) está em curso ao longo da vida de $\operatorname{Marx}^{227}$. E é apenas ao final do século XIX que teremos a concepção do habitat ${ }^{228}$, isto é, o isolamento da moradia em função e seu apartamento da cidade em si e, por conseguinte, a criação dos subúrbios: “com a 'suburbanização' principia um processo, que descentraliza a Cidade" (LEFEBVRE, 2006, p. 17). Germinação que não impediu, por parte de Marx, a visualização do papel central desempenhado pela relação cidadecampo na história, ao contrário, como vimos.

Desse modo, não me parece, nem era o objetivo comprová-lo, que a obra de Marx esgota os temas referentes às relações entre os indivíduos e a geografia do capital mundializada e urbanizada. O que me parece, e isso sim pretendeu-se comprovar, é que fornece fundamentos essenciais para a compreensão dessa relação, a partir da caracterização e crítica radical das formas de individualidade que se constituem nesta sociabilidade específica. Apontar para a geografia do ser social na modernidade, com efeito, permite apanhar o núcleo do processo em pauta: a superação da naturalidade dos pressupostos do trabalho e o rompimento da unidade entre estes e os homens, entre os indivíduos e suas condições de existência. Ademais, tal caracterização também permite retomar a crítica da ciência geográfica, encetando uma (entre outras) via de sua crítica ontológico - identificando a relação entre uma concepção específica de homem e o modo de ser dos homens que a fundamenta. Para tanto, dedicamos o excurso teórico a seguir.

\subsubsection{UM EXCURSO TEÓRICO: HOMEM E INDIVÍDUO NA ANTROPOGEOGRAFIA RATZELIANA}

Abrimos nosso trabalho com a apresentação dos aspectos fundamentais da crítica realizada à tradição geográfica no processo de renovação da disciplina. Vimos, no primeiro capítulo, que esta crítica acentua os elementos extra-científicos que intervêm na

\footnotetext{
${ }^{227}$ Lefebvre caracteriza o urbanismo de Haussmann como o primeiro ato do urbanismo capitalista.

${ }^{228} \mathrm{O}$ uso lefebvriano desta categoria é substancialmente distinto do apresentado no capítulo anterior deste trabalho.
} 
constituição da ciência geográfica. E, neste sentido, o viés epistemológico no entendimento da ideologia, isto é, a identificação desta com uma "falsa consciência", é hegemônico. Neste momento, propomos um excurso teórico que permita tanto a melhor caracterização dos limites referidos da crítica desenvolvida, quanto possibilite futuras aproximações no sentido de propiciar uma crítica ontológica à tradição geográfica.

Nesse sentido, a obra do prussiano F. Ratzel (1844-1904) impôs-se em nossa pesquisa tanto por seu pioneirismo na inserção do homem no novo quadro de referências teóricas e filosóficas que se esquadrinhava na segunda metade do século XIX $^{229}$ como, apesar do verdadeiro combate ${ }^{230}$ de que foi objeto, pela representatividade de suas ideias $^{231}$. Intencionamos aqui, porém, uma análise mais específica, centrando na concepção de homem presente em seus textos principais, na análise realizada por alguns críticos referenciais e no diálogo com a obra própria de Marx.

Friedrich Ratzel, expressão principal da Geografia alemã, apresenta, na obra a Antropogeografia, publicada pela primeira vez em 1882 e o segundo volume em 1891, considerações tanto de caráter epistemológico - referência às funções e tarefas da disciplina - quanto mais propriamente de âmbito ontológico - consideração do ser dos homens, sua especificidade e da sua relação com a natureza -, aqui apreciadas em conjunto, que evidenciam sua concepção do homem.

De início, Ratzel assenta a especificidade da ciência geográfica, no quadro geral das ciências positivistas: a consideração do território e das relações com ele estabelecidas pelos homens. De modo que, se "em toda a sociologia moderna o território merece tão pouca consideração que as obras que tratam dele a fundo nos aparecem como exceções" (RATZEL, 1990, p. 73), a Geografia, de outro lado, “imediatamente após a renovação realizada por Karl Ritter, dedica-se com grande amor ao antigo problema filosófico das relações recíprocas existentes entre a natureza e a humanidade, entre o teatro dos acontecimentos e a história" (RATZEL, 1990, p. 32). Isto é, "mesmo se atribuindo à história o estudo dos acontecimentos que se sucedem no tempo, à geografia as condições

\footnotetext{
${ }^{229}$ Trata-se do desenvolvimento do positivismo na ciência geográfica: "A incerteza terminou e o lugar do homem foi, por fim, firmemente assegurado na geografia através do trabalho de Frederich Ratzel e seus seguidores" (TATHAM, 1959, p. 574).

${ }^{230}$ Combate que resultou no já comentado relativo desconhecimento de suas ideias. Em língua latina, por exemplo, a única edição da Antropogeografia, e apenas do primeiro volume, é a italiana de 1914. Ademais, mesmo os parcos textos disponíveis em português, pouco são discutidos.

${ }^{231}$ No âmbito específico da Geografia Política, por exemplo, indica Claude Raffestin (1993, p. 14): "Se Ratzel abrisse hoje os manuais de geografia política geral, não se sentiria deslocado - exceto por algumas fórmulas e índices -, pois encontraria as categorias de análise utilizadas ou forjadas por ele".
} 
de fato do território, não se pode esquecer que todo acontecimento se faz no espaço, e por isso toda história possui seu teatro" (RATZEL, 1990, p. 90).

Neste passo inicial já deparamo-nos com o determinismo de sua concepção, na medida em que "tudo que se refere à natureza, ao ambiente, é imutável em comparação àquilo que se refere ao homem. /.../ determinadas condições naturais impõem ao movimento da vida sempre as mesmas vias e, renovando-se perenemente, colocam sempre e no mesmo sentido obstáculos ou limitações" (RATZEL, 1990, p. 90). A presença desse determinismo explícito ${ }^{232}$, que mais adiante será mitigado, ou mesmo reafirmado, ademais dos conflitos sociopolíticos gerais que contrapunham as duas principais nacionalidades presentes na geografia, por muitas vezes impediu uma análise mais aprofundada das ideias desse pensador, de todo modo útil e necessária ${ }^{233}$, sendo relativamente recente, como apontamos, o movimento de recuperação de seu pensamento ${ }^{234}$.

A Geografia Humana, enquanto ciência, para Ratzel, teria, então, como elemento central de consideração, a dinâmica das relações entre o homem e a natureza (por vezes apresentados como o povo e o território, respectivamente). Para além do determinismo, de fato presente em sua obra, vale perceber que Ratzel fundamenta sua proposição de uma ciência geográfica - que corrige a teoria social moderna ao considerar o território e sua importância para o "organismo" humano - num argumento, em certo sentido, ontológico, isto é, "quando se examina o homem, seja individualmente, seja associado na família, na tribo, no Estado, é sempre necessário considerar, junto com o indivíduo ou o grupo em questão, também uma porção de território" (RATZEL, 1990, p. 74). A apreciação científica das relações estabelecidas com o território radica, então, no fato do enraizamento territorial ${ }^{235}$ do homem: seja no indivíduo, na família, na tribo ou no

\footnotetext{
${ }^{232}$ Expresso, em outros momentos, de maneira ainda mais assertiva: "Na verdade o solo nos aparece como a causa mais profunda da sujeição humana, na medida em que permanece rígido, imóvel e imutável, abaixo das mutáveis disposições humanas, e se ergue dominador acima do homem toda vez que este ignora sua presença para adverti-lo severamente que a raiz da vida esta unicamente no solo. É ele que, duramente e sem nenhum critério de escolha, determina a cada povo o seu destino. Cada povo é obrigado a permanecer no solo que the foi destinado a viver e acomodar-se nele" (RATZEL, 1990, p. 81).

${ }^{233}$ Parece ser essa a mesma posição de $\operatorname{COSTA}$ (2004, p. 64): "Embora a rica perspectiva teórica de Ratzel não possa ser reduzida, em absoluto, à visão organicista e 'determinista' que muitos lhe impuseram, não há dúvida de que ele se inspirou na natureza biológica do homem para apresentar algumas de suas conclusões mais importantes em relação ao espaço e ao território".

${ }^{234}$ Vale citar, na Geografia Brasileira, Luciana de Lima MARTINS, (1993), e Marcos Bernardino de CARVALHO (1998).

${ }^{235}$ Posição que, aliás, encontramos em correntes diversas, inclusive críticas, do pensamento geográfico institucionalizado.
} 
Estado, "em todos esses casos nos encontramos diante de organismos que estabelecem com o solo uma ligação mais ou menos durável, em consequência da qual o solo exerce a sua influência sobre os organismos e aqueles sobre este" (RATZEL, 1990, p. 74). Notese aqui, de passagem, a caracterização de indivíduo, família, tribo ou Estado como organismos.

É desse fato, dessa dimensão concreta da existência dos homens, que emerge como problema central para o conhecimento a ligação dos homens com seu território, com a natureza, e de suas recíprocas influências, isto é, "vê-se nessa definição do objeto que, apesar de sua 'tríplice repartição', a questão das influências se sobrepõe, articulando as outras duas" (MORAES, 1990, p. 10). É extremamente útil, aqui, de todo modo, considerar a "tríplice divisão" supracitada dos objetos/objetivos da ciência proposta por Ratzel. Em primeiro lugar, é tarefa da Geografia, a fim de compreender "o homem dentro do quadro geral da vida terrestre" (RATZEL, 1990, p. 83) a averiguação do "estado de coisas antropogeográfico", isto é, "descrever e representar cartograficamente aqueles territórios onde se nota a presença do homem" (RATZEL, 1990, p. 83), o ecúmeno. Numa palavra, buscar responder a uma pergunta seminal: onde? Que, por sua vez, é compreendida apenas como passo inicial, pois logo surge, como um segundo grupo de tarefas, a questão: de onde? Isto é, ultrapassando a "tarefa descritiva" "se apresentarão então ao seu estudo os movimentos do homem na sua dependência do território" (RATZEL, 1990, p. 84) - isto é, como se formaram as áreas, como se difunde o elemento humano. Emergirão, daqui, um conjunto de considerações que já denunciam a complexidade das relações estabelecidas dos homens com a Terra, na medida em que se impõe a conclusão de que

diante de todos os movimentos que daí se seguem, a Terra não representa já um elemento totalmente passivo, mas os direciona, os obstaculariza, os favorece, os torna lentos, os acelera, os desordena e os ordena graças às suas condições incomensuravelmente variadas de posição, de amplitude, de configuração, de riqueza de água e de vegetação (RATZEL, 1990, p. 84).

Vale notar, nessa definição inicial do objeto da ciência, através da problematização de suas tarefas, que o homem aparece tão somente como um fato (e não um fator) geográfico, como um dado da paisagem - que cabe descrever e representar, em sua condição e movimento. E, nesse âmbito, muito embora seja o homem que esteja em movimento, o destaque recai no caráter ativo desempenhado pelo território. 
Retornemos, então, ao terceiro grupo de tarefas, que, como vimos de acordo com Moraes, articula os dois primeiros ${ }^{236}$ : o "estudo das influências que a natureza exerce sobre o corpo e sobre o espírito dos indivíduos, e daí sobre os povos" (RATZEL, 1990, p. 84). Note-se que a influência da natureza exerce-se, em primeiro lugar, sobre os indivíduos e, então, daí se estende aos povos. Com efeito, Ratzel (1990, p. 59) já identificara anteriormente, dentre as

\begin{abstract}
quatro formas de influência da natureza sobre o homem: $1^{\circ}$ ) Uma influência que se exerce sobre os indivíduos e produz nestes uma modificação profunda e duradoura; primeiramente ela age sobre o corpo e sobre o espírito do indivíduo e é por sua natureza fisiológica e psicológica; e só mais tarde passa assim ao âmbito da história e da geografia, isto é, quando se estende a povos inteiros.
\end{abstract}

Reconhece-se, e mesmo se considera central, primeira, profunda e duradoura, a modificação exercida pela natureza sobre o corpo e sobre o espírito do indivíduo, "sobre o ser e sobre as atitudes do homem" (RATZEL, 1990, p. 84). E, reintroduzindo questões de ordem epistemológica, é apenas quando esta se expande aos povos - através de qual mediação seja, não explicitada no momento - que se introduz na seara da ciência geográfica, no âmbito da história e da geografia. Este primeiro tipo de influência, assim, é objeto de outras ciências - fisiologia e/ou psicologia, nominadas. Posição que havia sido manifesta no trecho que analisávamos: "na verdade o exame destas influências compete mais à fisiologia e à psicologia do que à geografia" (RATZEL, 1990, p. 84).

Temos aqui, então, um primeiro exemplo da posição que exclui do âmbito da Geografia - ainda que "a geografia do homem ao descrever países e povos não poderá se desinteressar pelos conhecimentos adquiridos nesta matéria, na medida em que estes tocam diretamente todos os problemas relativos à aclimatação" (RATZEL, 1990, p. 84) - a consideração efetiva sobre a individualidade humana. Posição permanente em Ratzel que, em outro momento, acentua que "desde que a fisiologia estabeleceu assim a relação entre a natureza e o homem singular, e depois entre aquela e todo o povo, a geografia aceita esta relação como dada de fato e a utiliza para seus fins" (RATZEL, 1990, p. 58). De modo que a influência da natureza sobre a sociedade torna-se objeto da geografia tãosomente quando "este estudo contempla uma questão de espaço" - por exemplo, com relação àquela influência que se exerce sobre a mobilidade dos povos, "que direciona, acelera ou obstaculariza a expansão das massas étnicas. Esta determina a direção da

\footnotetext{
${ }^{236}$ Afinal, “é no jogo da relação homem-natureza que se alocam, segundo Ratzel, os fatores explicativos de tais processos" (MORAES, 1990, p. 10)
} 
expansão, sua amplitude, a posição geográfica, os limites” (RATZEL, 1990, p. 59), já mencionada anteriormente. Ademais, Ratzel menciona mais dois tipos de influências da natureza sobre a humanidade: sobre a "essência íntima" de cada povo ao propiciar o isolamento ou a miscigenação e, respectivamente, conservar ou diluir tais características (não exatamente explicitadas) e, por fim, sobre a "constituição social de cada povo" ao facilitar ou dificultar o trabalho social, isto é:

\begin{abstract}
$3^{a}$ ) uma influência mediata sobre a essência íntima de cada povo que se exerce impondo a ele condições geográficas que favorecem seu isolamento e por isso a conservação e a reafirmação de determinadas características, ou facilitando a miscigenação com outros povos e portanto a perda das próprias características. $4^{\mathrm{a}}$ ) Finalmente uma influência sobre a constituição social de cada povo que se exerce para oferecer-lhe maior ou menor riqueza de dotes naturais, ao facilitar-lhe ou tornar-lhe difícil primeiramente a obtenção dos meios necessários à vida, e depois dos meios necessários ao exercício da indústria e do comércio e pois a obtenção de riqueza por meio da troca (RATZEL, 1990, p. 59-60)
\end{abstract}

Para, então, concluir enfaticamente: "como se vê, destas quatro questões as três últimas têm estreita conexão com a geografia enquanto a primeira nada tem a ver com esta" (RATZEL, 1990, p. 60), fato que o leva a examinar os problemas relativos à que se exerce sobre os indivíduos antes mesmo de se aprofundar sobre as questões propriamente geográficas.

É nessa consideração prévia, enfim, que podemos investigar alguns elementos centrais de sua concepção do homem e do indivíduo - e sua associação com a noção de natureza. Uma primeira verificação, simples, constitui interessante ponto de partida: o fato de que Ratzel, em todos os momentos, identifica a individualidade como objeto de duas ciências, a fisiologia e a psicologia - o homem é considerado enquanto ser biológico e psíquico, no máximo. A ausência mesmo, por exemplo, da sociologia (como veremos em outros geógrafos), ainda que mantendo-nos na dimensão epistemológica da questão (e dentro dos limites da sociologia positivista), expressa a não consideração do homem como ser social.

Encontramos, então, afirmações que mitigam o determinismo inicial, isto é, "verifica-se de todo modo como era escasso o fundamento do conceito de que os povos podem se adaptar exatamente ao seu ambiente como se este fosse uma massa plástica, de modo a se tornar com o tempo um espelho do próprio ambiente” (RATZEL, 1990, p. 62). Atenuação do determinismo, porém, que se efetiva no bojo de uma concepção que reafirma um organicismo naturalista de talhe positivista, ou seja, quando se aborda a afirmação da "individualidade humana em meio às influências exteriores" o faz no 
contexto de uma argumentação fundada explicitamente em Darwin, Spencer e Comte: homem é entendido enquanto um organismo análogo a qualquer outro, esvaecendo suas características específicas e peculiares - em especial sua natureza social. Em seus termos, “o homem é um organismo que segue as próprias leis e que sempre de acordo com estas, embora de forma independente, elabora tudo aquilo que lhe provém do exterior" (RATZEL, 1990, p. 61). Ainda, assim, que siga suas próprias leis, aparentemente se tratam de leis naturais, biológicas, como se constata na argumentação subsequente:

\begin{abstract}
O fato de as formas orgânicas se modificarem com a mutação das condições externas pode ser considerado hoje como universalmente aceito; a isso porém se acrescenta uma constatação experimental de importância não menos universal, isto é, que frequentemente tais modificações no indivíduo encontram logo um limite além do qual se tornam insignificantes; que, por outro lado, diante de influências externas da mesma intensidade nem todos os organismos se modificam na mesma medida, e que finalmente quando cessa a ação dessas influências verifica-se um retorno à forma primitiva, de modo que se pode dizer que a forma, a individualidade do organismo tem uma forte tendência a se manter (RATZEL, 1990, p. 61).
\end{abstract}

Mais uma vez, podemos afirmar que mesmo a ausência da sociologia denota que as leis próprias da individualidade humana não são leis sociais. Em suma: quando se infirma o determinismo, temos uma argumentação de acentuado teor naturalizante, organicista - daí podendo se depreender importantes inferências em relação à concepção de indivíduo, que desdobraremos mais adiante.

Antes, porém, vale reter algumas notas acerca da própria noção de condições externas e, mesmo, de natureza presente nas considerações analisadas, que, nos parece, se associam com a própria argumentação contra o determinismo. Isso porque as "influências naturais" que se exercem sobre os indivíduos referem-se ao ambiente físico em que o homem se insere - elemento crucial ao entendimento da categoria de homem atópico. Quando aborda o conjunto das influências exercidas pela natureza, é enfático no reconhecimento de que "trata-se portanto, essencialmente, de efeitos que se devem ao clima, à configuração do solo, aos produtos vegetais ou animais do território. /.../. Assim vemos o ambiente físico refletir-se na religião, na ciência, na poesia" (RATZEL, 1990, p. 84). Embora, no exame da evolução dos conceitos acerca das influências da natureza sobre a sociedade, reconheça a complexidade da noção de milieu a partir de Lamarck "um conceito totalmente diverso daquele de ambiente natural de Buffon" (RATZEL, 1990, p. 42) -, mal compreendido mesmo entre aqueles que objetivaram aplicá-lo, como Comte, "à evolução dos povos e à história da humanidade" (RATZEL, 1990, p. 47), o que temos em suas considerações é a manutenção do entendimento de um ambiente físico, 
a determinar e/ou influenciar a individualidade humana, os movimentos dos povos, sua essência íntima e constituição social.

Por exemplo, numa argumentação com Ritter, exatamente acerca das influências do ambiente físico sobre os homens, afirma:

Mas os espaços terrestres, considerados como 'habitação do gênero humano',
não permaneceram imutáveis, especialmente porque o homem, mediante
novos meios que busca para si (por exemplo, as comunicações), modifica suas
relações com eles, e também pelo efeito das transformações que a Terra por si
própria sofre (RATZEL, 1990, p. 47).

Grifemos: os homens modificam suas relações com a natureza, utilizando de modo mais hábil e intenso as condições naturais.

Já no tópico intitulado "As influências do ambiente físico se modificam com a história", Ratzel fornece importantes indicações acerca de sua compreensão do homem, aquele que tem "a organização mais completa", entre os seres vivos, dada, em especial, a sua capacidade racional, intelectiva: "ele possui na própria razão o meio de buscar para si outros instrumentos além daqueles que lhe são próprios por natureza para empregar na obtenção de objetivos bem determinados" (RATZEL, 1990, p. 71). Chegamos próximos, enfim, à caracterização do trabalho, da atividade sensível consciente (nos termos de Marx $)^{237}$, e o determinismo é, novamente, mitigado, agora de maneira decisiva a partir do reconhecimento da especificidade do homem, pois "com isso ele vai se tornando sem dúvida mais independente da sua constituição natural. /.../. O homem pode portanto considerar-se como um ser independente em comparação com o animal, que é muito menos, pelo de que graças ao seu intelecto o homem está mais livre dos vínculos da sua constituição natural" (RATZEL, 1990, p. 71). O homem é capaz de utilizar a razão, o pensamento para conseguir outros meios de produção, outras ferramentas, que progressivamente o libertam de sua configuração natural.

A independência da constituição natural, é importante perceber, para clarificar sua argumentação, não significa a libertação em relação à "natureza que constitui o seu substrato e o seu ambiente" (RATZEL, 1990, p. 71) e isto porque "para conquistar esta liberdade é necessário por outro lado que ele utilize habilmente os recursos que a natureza circundante lhe oferece" (RATZEL, 1990, p. 71). Assim, para o geógrafo prussiano, é

237 Concepção na qual, vale considerar, inicialmente, “o momento essencial é constituído não pela fabricação de produtos, mas pelo papel da consciência, a qual, precisamente aqui, deixa de ser mero epifenômeno da reprodução biológica: o produto, diz Marx, é um resultado que já no início do processo existia 'na representação do trabalhador', isto é, no plano ideal” (LUKÁCS, 2007, p. 228-9). 
fundamental diferenciar a dependência da natureza e a subordinação em relação à mesma, de modo que “a denominação de 'povo primitivo' (povo natural) não indica um povo que viva na relação mais íntima possível com a natureza, mas antes um povo que, se se nos permite a expressão, vive sob o império desta" (RATZEL, 1990, p. 72) e, de outro lado, a civilização consiste exatamente na superação dessa subordinação, desse império, através do uso mais sagaz da natureza. Enfim, "podemos afirmar que a diferença entre povo primitivo e povo civilizado deve ser buscada não no grau mas no tipo de ligação que existe entre o homem e a natureza. A civilização é independente da natureza não no sentido da completa libertação, mas no sentido de uma ligação mais diversificada, mais ampla e menos imperiosa" (RATZEL, 1990, p. 72).

Mais um trecho pode evidenciar um aspecto fundamental de sua argumentação: "Pode-se portanto aceitar como regra que uma grande parte dos progressos da civilização são obtidos mediante um desfrute mais perspicaz das condições naturais, e que neste sentido esses progressos estabelecem uma relação mais estreita entre o povo e o território" (RATZEL, 1990, p. 72). Enfim, o homem pode obter um desfrute mais perspicaz das condições naturais, ou então uma ligação mais diversificada, mais ampla e menos imperiosa na medida em que ele utilize habilmente os recursos que a natureza circundante lhe oferece, como diz em outro trecho, estabelecendo com a Terra um contato cada vez mais íntimo e utilizando com mais habilidade as condições dadas. Em suma, em todos os momentos analisadas, a posição de Ratzel, como aliás ele mesmo anunciou de início, é no sentido de que o homem modifica suas relações com os espaços terrestres através dos progressos da civilização, de seu trabalho, ou melhor, do intelecto. Em momento algum, ao menos na Antropogeografia, sua obra de maior influência, o homem aparece como o produtor do meio em que vive, nem ao menos como um "fator antrópico" de transformação da natureza. Isto é, o homem pode utilizar as condições naturais preexistentes, mas não criar, engendrar novas condições, concepção que levará, como veremos, à perda da unidade homem e natureza.

Adentramos, assim, na problematização dessa relação, ou ligação, do homem com o território que oportuniza, dada sua condição central na propositura científica de Ratzel, o desdobramento da concepção do mundo e do homem do geógrafo prussiano, permitindo verificar os efeitos e determinantes da dimensão apresentada - objetividade do mundo enquanto dimensão naturalmente dada que pode ser, no máximo, usada. 
Para Ratzel, "em meio a muitas variações que se sobrepõem, as relações entre sociedade e território continuam sendo sempre determinadas pelas necessidades de habitação e de alimentação" (RATZEL, 1990, p. 72). Temos, então, uma concepção de território que radica na apropriação econômica do solo - como base e ponto de partida, da existência humana e, portanto, da consideração teórica. Tal apropriação é fundante e fundamental - no que estaríamos, mais uma vez, numa possível aproximação com o pensamento de Marx. Veremos adiante o quanto essa aproximação é efetiva. Vale acompanhar sua argumentação. Enquanto "a necessidade de habitação é de natureza tão simples que em qualquer época estabeleceu entre o homem e o solo as mesmas relações" (RATZEL, 1990, p. 74), a alimentação, por sua vez,

representa a necessidade mais imperiosa tanto para o indivíduo como para a sociedade, pois as obrigações que impõe tanto a esta quanto àquele precedem a todas as outras. Quer o homem se proveja através da caça ou da pesca, ou através da coleta de frutas, a escolha do local de moradia e a amplitude do território do qual são trazidos os alimentos sempre estiveram subordinadas às exigências de alimentação (RATZEL, 1990, p. 75).

A partir dessa dimensão primária, é possível verificar o trânsito da apropriação econômica à apropriação política: o território que garante a satisfação das necessidades de moradia e alimentação deve ser protegido e, para isso, a sociedade, a comunidade, se organiza na forma de Estado. Ou seja,

em Ratzel, é no elo indissociável entre uma dimensão natural, física, e uma dimensão política (que aqui se confunde com estatal) do espaço que o território se define. Esta concepção acaba de alguma forma se aproximando daquele que, valorizando a dimensão econômica, vê o território como fonte de recursos para a reprodução da sociedade, pois é também com base nesta disponibilidade de recursos que Ratzel vai construir seu conceito. $\mathrm{O}$ 'espaço vital' seria assim o espaço ótimo para a reprodução de um grupo social ou de uma civilização, considerados os recursos aí disponíveis que, na leitura do autor, devem ter uma relação de correspondência com as dimensões do agrupamento humano nele existente (COSTA, 2004, p. 66).

A apropriação política, por sua vez, se associa a uma dimensão, digamos, ideal de apropriação, isto é, à identificação e harmonia que se estabelece entre a comunidade e o solo apropriado: "a humanidade vai se apegando cada vez mais à Terra, harmoniza-se cada vez mais com ela e se multiplica estabelecendo com a Terra um contato cada vez mais íntimo e utilizando com mais habilidade as condições dadas" (RATZEL, 1990, p. 47). O progresso na utilização da natureza intensifica e solidifica o vínculo estabelecido entre a sociedade e o território em que vive. É uma argumentação extremamente semelhante à que podemos encontrar em outro trecho: "Pode-se dizer ainda, em um sentido mais geral, que a civilização traz consigo o fortalecimento de uma ligação mais íntima entre a comunidade e o solo que a recebe" (RATZEL, 1990, p. 72). Ratzel afirma, 
em suma, que os progressos da civilização tornam mais íntima a relação do povo com o território e, portanto, intensificam e solidificam o vínculo, a identificação estabelecida com ele.

Novamente, se trata de um aspecto de seu pensamento recentemente recuperado: "é interessante perceber, contudo, que o enfoque de Ratzel não se resume a uma perspectiva materialista, em sentido estrito. Releituras relativamente recentes têm enfatizado a relevância do lado 'espiritual' e mais subjetivo de sua obra" (COSTA, 2004, p. 66), que, com efeito, se explicita intimamente articula com a questão do Estado:
A 'ligação espiritual com a terra' que Ratzel defende faz desse território estatal muito mais do que uma entidade material. O sentido orgânico 'ótimo' almejado pelo Estado passa pela ideia de que é graças ao território, ou melhor, ao 'solo', que a nação supera suas misérias e alcança as condições para a projeção de seu 'poder criativo' (COSTA, 2004, p. 66).

É o que se encontra, na Antropogeografia, de referência à dimensão subjetiva da realidade - aspecto intimamente relacionado à dimensão político-ideológica do discurso geográfico.

Em resumo, acerca do homem na Antropogeografia temos: um ser vivo, um organismo, terrestre, que análogo aos demais seres vivos, enquanto um organismo, têm suas próprias leis e, igualmente, por deter a capacidade de raciocínio que o permite se libertar de sua constituição natural ao acentuar sua dependência em relação à natureza (que continua sendo um elemento dado, fornecido por dinâmicas e relações exteriores ao próprio homem), com a qual entra em relação a fim de satisfazer suas necessidades de sobrevivência e reprodução, hegemonizadas pelas necessidades de moradia e alimentação. A intensificação e solidificação da apropriação econômica é raiz para seu duplo desdobramento em apropriação política e apropriação ideal - o território é defendido pelo Estado e se produz uma identificação entre a comunidade e o solo. $\mathrm{O}$ homem, conquanto exista o indivíduo, só é considerado enquanto povo, sociedade, comunidade - muito embora não se problematizem as relações sociais estabelecidas, ainda que anteriormente reconhecidas como objeto da ciência. 


\section{CONSIDERAÇÕES FINAIS}

A presente pesquisa configurou-se enquanto uma pesquisa de caráter exploratório, com o objetivo de evidenciar, discutir e problematizar os pressupostos de uma abordagem do pensamento geográfico de Marx, tomando como referência os recentes esforços de descoberta e recuperação do seu caráter ontológico e, nestes, das questões relacionadas ao problema da individuação e da individualidade humano-social. Nesse sentido, associou-se também ao movimento de crítica da tradição geográfica, que se caracteriza especialmente pela apropriação do pensamento marxista, e com ele buscou estabelecer, permanentemente, pontos de intersecção, diálogos e críticas, bem como com as próprias matrizes clássicas da ciência geográfica. Portanto, não estabelecia uma tarefa propriamente explicativa, mas objetivava esclarecer, pontuar e levantar questionamentos. Ainda com estes objetivos, podemos encaminhar as considerações conclusivas.

Da interação com as matrizes clássicas, mediada por posições no interior do movimento de renovação, destaquemos o entendimento de que a noção basilar da geografia (da realidade e, por conseguinte, da ciência) corresponde à localização, isto é, “só passam a ser considerados geográficos os fenômenos passíveis de fixação em certo e determinado lugar. Esse lugar pode ser grande ou pequeno, a superfície da Terra ou a área de um simples coro, não importa, o fundamental para a geografia é que haja um local" (BACKHEUSER, 1944, p. 399). Ou, melhor, ainda, de que "a localização é pois, mais do que um princípio basilar da geografia porque é a sua mesma essência” (BACKHEUSER, 1944, p. 399). Remeter à localização, em realidade, significa remeter às relações entre os fenômenos, na medida em que os seres e processos que conformam a objetividade põemse, unicamente, através e por meio de interações contínuas e, por conseguinte, configuram uma rede complexa de distribuições. Assim, identificamos a existência de um pensamento geográfico na medida em que sistematize e explicite compreensões e reflexões acerca da localização e distribuição dos fenômenos - seres, processos e relações. E, na medida em que todos os seres humanos encontram-se em relações determinadas com as demais formas de ser que constituem a natureza, localizam-se, necessitando demarcar explicitamente esta localização, bem como dos demais seres com os quais se relacionam. Todos, portanto, inserem-se em uma determinada geografia e constituem, em diferentes níveis de apreensão ideal, distintas formas de consciência geográfica. Nas formas mais elaboradas e complexas do pensamento humano, teremos, 
por via de consequência, vias de reflexão mais elaboradas e complexas acerca dessa dimensão da realidade - às formas mais organizadas e sistematizadas, Moraes resguarda a noção de pensamento geográfico.

Desse modo, uma primeira via da abordagem geográfica do trabalho corresponde à identificação das localizações e distribuições compreendidas no processo de individuação, tal como apreendido por Marx. Para tanto, tornou-se imprescindível bem delinear sua dinâmica essencial, apreendida no processo mesmo através do qual Marx institui um pensamento próprio e original, para o qual reservamos o termo marxiano. $\mathrm{O}$ segundo capítulo, assim, expressa o movimento do objeto, qual seja, o próprio pensamento marxiano com o fito de apreender a forma específica de compreensão do mundo e dos homens que se constitui.

As determinações ontológicas essenciais se evidenciaram nessa análise - a identificação do ser à objetividade e, nesta, seu caráter relacional. Ainda no que se refere à determinação do ser, mais geral, temos o reconhecimento do padecimento, das interações recíprocas e necessárias entre os seres, isto é, o reconhecimento de sua complexidade. E, quanto ao ser social, o agregado das dimensões da socialidade e, especialmente, da atividade consciente, demarcando sua diferença específica em relação às demais formas de ser. Determinações extraídas do quadro mais geral de oposição à filosofia especulativa e às formas de reflexão que naturalizam o modo de ser existente eixo da crítica de Hegel aos economistas clássicos, passando por Feuerbach. Oposição e crítica que se associam, por sua vez, ao intento de transformação revolucionária do mundo e, só aí, encontram sua plena justificativa, enfim, "uma filosofia que se constitui como representação radical - conhecer o mundo até o fim, até à raiz; e que se realiza no mundo, também por uma prática de raiz, por uma ação transformadora que vai até o fim revolução" (CHASIN, 1987, p. 45). Por fim, também relacionado a este intento maior e que a tudo abrange, temos o reconhecimento da totalidade enquanto determinação ontológica, ou seja, da existência e essência dos seres, isto é, o pensamento dos homens “procedente do mundo, ao mundo retorna. Não para uma tarefa tópica ou para alguma assepsia formal. Volta ao mundo para tomá-lo no complexo de complexos de sua totalidade" (CHASIN, 1987, p. 45). Em suma, apenas a apreensão da totalidade, enquanto dimensão real e efetiva, permite pensar em uma transformação total do modo de vida dos homens. 
Desdobrando e particularizando, é necessário mais uma vez apontar para a radicalidade e originalidade do pensamento marxiano, que se manifesta, em nosso estudo, na compreensão do processo de individuação. Os indivíduos humanos, vivos e ativos, não apenas são apreendidos como o único ponto de partida válido para qualquer compreensão da história, como são entendidos, eles mesmos, enquanto seres históricos, isto é, que se configuram e conformam no, como dizem Marx e Engels, próprio suceder das gerações. Numa palavra: os seres humanos apenas se individualizam no decorrer da história. No que não é possível conceber qualquer forma de teleologia linear, mas o resultado do incremento da potência ativa da humanidade - que se manifesta, por suposto, na singularidade. O desenvolvimento do gênero humano implica necessariamente no desenvolvimento de suas individualidades ${ }^{238}$.

A rigor, se então interrompêssemos o trabalho, não se trataria de uma discussão geográfica. Ainda que nossa atenção já se direcionasse a alguns temas em especial (e os apontamos em cada caso), o intuito era respeitar a lógica imanente do objeto (e não imputar aquilo que desejávamos reconhecer), demanda fundante e fundamental do próprio esforço científico (seu atendimento efetivo é o que, nos parece, cabe avaliar). Neste passo, entretanto, podemos atentar, por exemplo, para o caráter histórico e social dos homens, bem como em sua dinâmica autoconstitutiva, na qual, ao produzirem um mundo objetivo, instauram um mundo subjetivo, um sentido correspondente. Como vimos, a música cria o ouvido musical. O que nos faculta indicar que, ao produzirem sua geografia, criam os homens um sentido correspondente para sua apreensão, um sentido de localização, que tratamos, de modo preliminar, como sua consciência geográfica. Trata-se de um tema a ser posteriormente aprofundado e desdobrado na perspectiva teórica aqui explicitada ${ }^{239}$. Enfim, principalmente no quarto capítulo, por sua vez, esforçamo-nos no sentido de apreensão da geografia do processo de formação da individualidade humana, efetivado no longo e contraditório processo de autoconstrução

\footnotetext{
238 Poder-se-ia, talvez, apor-se um questionamento em relação à noção de desenvolvimento, tomada como uma possível comprovação do caráter evolucionista do pensamento marxiano. Vale destacar que se, com efeito, não podemos negar, na obra marxiana, a presença da ideia de evolução, de progresso cultural, talvez possamos associá-la à noção de complexidade. Isto é, é mais desenvolvido, aquilo que é mais complexo e diversificado, desenvolvendo as potencialidades presentes na própria realidade, na própria natureza, tanto a humana, quanto a exterior aos homens. Assim, na mesma passagem em que Marx (2011, p. 58) afirma que "a sociedade burguesa é a mais desenvolvida e diversificada organização histórica da produção", apresenta a crítica direta a qualquer forma de evolucionismo: "o assim chamado desenvolvimento histórico se baseia sobretudo no fato de que última forma considera as formas precedentes como etapas até si mesma, e as concebe sempre unilateralmente, uma vez que raramente critica a si mesma, do que é capaz apenas em condições muito determinadas" (MARX, 2011, p. 59).

${ }^{239}$ Em distinto diapasão teórico, Leal (2010) abordou recentemente a temática.
} 
dos homens - aí, sim, buscando evidenciar a dimensão geográfica, novamente, tal como apreendida por Marx. Antes de retomar estas reflexões, no entanto, registremos outra dimensão do trabalho.

Intermediando e permeando este esforço de perscrutar a análise marxiana, com efeito, encetamos uma segunda via de abordagem geográfica - em torno da tradição científica que objetiva, também de maneira complexa e contraditória, analisar e explicar a ordem tópica da realidade e as relações das sociedades com esta ordenação espaçotemporal, configurada enquanto campo disciplinar desde meados do século XIX. No primeiro capítulo, já buscávamos caracterizar o movimento de crítica a esta tradição, com destaque para a apropriação do marxismo que então se opera e para a crítica às noções de homem e de indivíduo. Constatamos, por exemplo, a refutação da fragmentação operada pelas matrizes clássicas da ciência geográfica, em que se destaca a oposição entre o homem e a natureza, bem como a identificação de um homem passivo, o homemhabitante, presente neste discurso. Verificamos, igualmente, a explicação destas características pelo prisma de acentuar os compromissos extracientíficos da disciplina, enquanto uma ideologia que objetiva obnubilar ou obscurecer dinâmicas da realidade, evidenciando, assim, a hegemonia de um viés epistemológico no entendimento desta categoria - no que, inclusive, não se diferencia do rumo que tomou no interior do próprio marxismo.

O diálogo com a tradição geográfica prosseguiu - abarcando suas matrizes clássicas - no terceiro e no quarto capítulos. Naquele, intentamos problematizar, reconhecidamente de forma preliminar e apenas para orientar o esforço em questão, o modo como se põem as complexas relações entre ontologia e ciência na posição marxiana, no que destacamos seu caráter fundamental - o entendimento da teoria, em qualquer dimensão e resguardadas suas especificidades, como a busca da apreensão do serprecisamente-assim da realidade, contrariando, assim, todo o clima teórico dominante, de ao menos duzentos anos, que afirma a impossibilidade do saber. Ao contrário, para Marx, e assentado nos fundamentos delineados no segundo capítulo, temos a afirmação radical da possibilidade do saber, na medida em que uma das dimensões do ser dos homens. Numa palavra: impossibilitados de saber, estariam os homens também impossibilitados de confirmarem ativamente a si mesmos, de serem. Desdobramos, por conseguinte, acompanhando alguns estudiosos da ontologia marxiana, uma das consequências da afirmação da centralidade da atividade consciente enquanto atividade vital dos homens. 
As categorias constituem, nessa acepção, modos de ser, manifestações da existência reprodução ideal de manifestações do real. É exatamente nesse sentido, ainda, que problematizamos a ideia da geografia enquanto determinação do real, interagindo com a noção apresentada e discutida por Pierre Monbeig de complexo geográfico. Delineada, em traços gerais, esta dimensão (enquanto uma articulação coerente de categorias relacionadas à ordem da coexistência no âmbito das relações entre sociedade e natureza), buscamos evidenciá-la na análise marxiana do processo de individuação. Alcançamos, então, o quarto e último capítulo.

Neste, problematizamos o entendimento de que originalmente, na situação de restrição das capacidades humanas e, por conseguinte, de sua subsunção ao meio natural (e à geografia natural, em diferentes níveis e dimensões), temos os indivíduos tão somente como adjacências, emanações de seus agrupamentos naturais, de sua família - ou, mais geral, de sua família ampliada, isto é, da comunidade. Para este primeiro tipo de formações, as comunitárias, temos, no interior de suas variadas configurações territoriais, o predomínio mais amplo de um complexo geográfico rural-em que, mesmo que apareça a cidade, esta se põe hegemonizada por elementos e dinâmicas do campo e da atividade agrícola (Marx refere-se, por exemplo, a traços de feudalidade na cidade medieval). Temos, então, tempos, ritmos e espaços demarcadamente locais e oriundos das dinâmicas naturais, em especial, dos fenômenos climáticos e biogeográficos. Registrando a emergência de uma individualidade restringida, em que seu próprio objetivo é tão somente a reprodução das condições que lhes são pressupostas. O limite, assim, é sua marca essencial. Explicitada, por exemplo, no âmbito de uma consciência geográfica que, embora integral do meio em que se o indivíduo se insere, corresponde a um meio único, determinado e limitado - sua concha.

Por sua vez, o desenvolvimento da produção humana, no intercâmbio metabólico com a natureza, implicou num contraditório e inexorável processo de "afastamento das barreiras naturais" através do qual os homens não se tornam independentes da natureza, mas superam paulatinamente a subordinação em relação aos pressupostos de sua atividade que são postos espontaneamente, através e por meio da própria produção destes pressupostos, quais sejam, a comunidade e o território. Passo no qual se torna imprescindível demarcar o caráter contraditório desta produção dos pressupostos do trabalho, realizada no âmbito da subsunção dos indivíduos à lógica do valor. Isto é, os indivíduos não se encontram mais subordinados a pressupostos naturais, mas também 
não controlam suas próprias forças, pois, num processo complexo e contraditório, a produção social desses pressupostos efetiva-se no marco e sob o signo da exterioridade. Os homens são separados das condições de sua existência, de sua própria generidade, dentre elas o território, que passam a se opor aos próprios indivíduos - e os indivíduos a se opor uns aos outros, indiferentes e equivalentes. Estamos no reino da individualidade cindida, isto é, na geografia urbana moderna - sede e plataforma da relação capital. Assim, se apenas agora podemos referir a um mundo de indivíduos, materializado na cidade do capital, trata-se de um mundo em que estes indivíduos defrontam-se uns com os outros, na busca de seus interesses particulares, enquanto proprietários privados que encaram todo o gênero humano como meio de atingir suas finalidades.

Temos, então, um novo caráter das relações dos indivíduos com as condições de sua existência, a comunidade e o território, isto é, entre si mesmos e a terra enquanto fonte última da apropriação de valores de uso, marcada pela exterioridade, pela acentuação da alienação e do estranhamento. Que se manifestam, por sua vez, como já demarcava Lacoste e sua apreensão da espacialidade diferencial, em suas representações espaciais cada vez mais confusas e indiferenciadas. Temos um sentido de localização alienado, ou então, um sentido da localização alienada, na qual os homens não reconhecem a ordenação espaço-temporal em que se inserem e, mais se defrontam em relação à ela como algo que se lhes opõe. Nestas novas relações, também, acentua-se o caráter de meio do próprio trabalho - a atividade fundante e fundamental dos homens é reduzida a fonte de obtenção da subsistência, e os homens submetidos à coerção puramente econômica. $\mathrm{O}$ espaço monumental, que integrava os indivíduos num todo, cede lugar ao lugarmercadoria. Aqui, também, um tema a ser desdobrado em momentos futuros.

Por fim, o diálogo com as matrizes clássicas, no último capítulo de nossa dissertação, realizou-se tanto para auxiliar no desvendamento das categorias geográficas que expressam o processo de individuação, como em especial no excurso teórico na obra ratzeliana, a fim de evidenciar as limitações do entendimento puramente epistemológico da ideologia. Aqui, pudemos verificar que as concepções de homem e indivíduo nesta matriz clássica da ciência geográfica, para além da mistificação e ocultação (do papel das classes e do Estado) e justificação (do imperialismo), efetivamente presentes, constituem uma expressão (alienada, naturalizada) da individuação burguesa, em outros termos, à apreensão de sua aparência fenomênica. Isto é, expressam uma individualidade em oposição ao seu gênero, lançada num mundo regido por forças externas e estranhas que, 
embora seu produto (social), não se encontram sob seu controle, e, mais, submetida às pressões da sobrevivência material imediata. Em suma, o homem atópico é, em realidade, o homem urbano no capitalismo, a individualidade cindida cujas características e pressupostos materiais discutimos anteriormente.

Em outras palavras, o conceito de homem presente na ciência geográfica, atravessando diversas de suas correntes (e cada diferença específica merece consideração própria), não pode ser explicado apenas pela dimensão política-institucional do discurso. Isto é, a noção de homem-habitante (ou homem atópico) não pode ser entendida apenas como função da necessidade de expurgar os conflitos (as relações de produção) do âmbito da análise - muito embora esta dimensão esteja presente, na medida em que as matrizes clássicas da ciência geográfica inserem-se no período da decadência ideológica da burguesia - nem como elemento necessário à afirmação da legitimidade institucional da disciplina, e seu afastamento (no que se refere ao objeto) das demais disciplinas.

O que se afirma, aqui, é que a concepção de homem e do mundo referenda-se num conjunto determinado de relações sociais (seus pressupostos materiais), de um modo de ser dos homens - no caso, as relações de produção capitalistas e sua espacialidade diferencial. Isto é,

é verosímil que o que se denomina ideologia ou tal se presume (filosofia, religião, ética ou estética, 'cultura', moral e moralidade) tenha servido mais de diversão, de divertimento, do que de instrumento. /.../. As ideologias que agem, actuantes, estiveram e continuam a estar ligadas imediatamente a uma prática (LEFEBVRE, 1973, p. 11).

O mesmo Lefebvre (1979, p. 47) lembra ainda que, "para Marx, a consciência (social) que nasce de uma práxis só reflete fielmente essa práxis em situações bastante definidas: quando a própria práxis não está envolvida em véus nebulosos e as relações entre os seres humanos permanecem diretas, sem intermediários 'opacos"”. Este não é o caso, muito pelo contrário, da formação social capitalista - na qual o fetichismo alcança seu mais puro estágio. De modo que, nessas situações, a prática social dos homens erige o que o pensador francês chama de representações: "A realidade social, isto é, os homens e os grupos humanos em suas interações, produz aparências, que são algo além e diverso de ilusões sem consistência" (LEFEBVRE, 1979, p. 47). Ou então, como resume Lukács (2012, p. 31), a "práxis postula por si só, necessariamente, uma imagem de mundo com a qual possa harmonizar-se e a partir da qual a totalidade das atividades vitais produz um contexto pleno de sentido". 
Compreender o discurso geográfico clássico - e sua categoria de homem atópico - nesse diapasão pode ser um fértil caminho para apreender efetivamente sua função social, isto é, sua necessidade no quadro da individuação burguesa. E também lança luzes sobre a sua reprodução nas práticas escolares da disciplina, mesmo com todo o processo de crítica à seus compromissos políticos-ideológicos. Em suma, tal apreensão, de uma determinação social mais ampla do discurso geográfico, torna-se imprescindível na medida em que se compreende que opor-se a tal noção é, por conseguinte, opor-se ao modo de ser que lhe subjaz. Ou então, em associar-se a outro tipo de práxis. 


\section{REFERÊNCIAS BIBLIOGRÁFICAS}

ALBUQUERQUE, M. A. M. Século de prática de ensino de geografia: permanências e mudanças in REGO, N.; CASTROGIOVANNI, A. C.; KAERCHER, N. A. (orgs.). Geografia: práticas pedagógicas para o ensino médio: volume 2. Porto Alegre: Penso, 2011.

ALCKMIN, R. M. Feuerbach e Marx: da sensibilidade à atividade sensível. Dissertação de mestrado, UFMG, 2003.

ALVES, A. J. A individualidade moderna nos Grundrisse. Ensaios Ad Hominem 1 - Tomo IV: Dossiê Marx, Santo André, Estudos e Edições Ad Hominem, 2001.

A cientificidade na obra marxiana de maturidade: uma teoria das daseinsformen. Tese de doutorado, Unicamp, 2012.

ANDERSON, J. "Ideologia em Geografia: Uma Introdução”. In Seleção de Textos, São Paulo, AGB, n. 3, set. 1977.

ANDERSON, P. Considerações sobre o marxismo ocidental. São Paulo, Boitempo, 2004.

ANDRADE, M. C. Geografia: Ciência da Sociedade: Uma introdução à análise do pensamento geográfico. São Paulo, Atlas, 1992.

ANTUNES, C. F.; SOUSA NETO, M. F. de. Os estudantes, a Associação dos Geógrafos Brasileiros (AGB) e o movimento de renovação crítica da geografia brasileira. In: Boletim Paulista de Geografia, São Paulo, Seção São Paulo - Associação dos Geógrafos Brasileiros, n. 88, jul. 2008.

BACKHEUSER, E. Os fatos fundamentais da geografia. Boletim geográfico, IBGE, Rio de Janeiro, v. II, n. 16, 1944.

BARROS, R. C. S. O ser genérico: pressuposto da crítica da política do jovem Marx. Dissertação de mestrado, Unicamp, 2006.

BENSAÏD D. "Na e pela história." Reflexões acerca de Sobre a questão judaica. In: MARX, K. Sobre a questão judaica. São Paulo, Boitempo, 2010

Los desposeídos: Karl Marx, los ladrones de madera y los derechos de los pobres. Buenos Aires, Prometeo, 2011.

BERDOULAY, V. A abordagem contextual. Espaço e cultura, UERJ, Rio de Janeiro, n. 16, jul./dez. 2003.

BERNARDES, N. O pensamento geográfico tradicional. Revista Brasileira de Geografia, Rio de Janeiro, 44 (3): 391-413, jul./set. 1982.

BOITO JÚNIOR, A. Emancipação e revolução: crítica à leitura lukacsiana do jovem Marx. Crítica marxista, Campinas, n. 36, 2013.

BORON, A. Filosofia política marxista. São Paulo/Buenos Aires, Cortez/Clacso, 2003.

BRASIL. Secretaria de Educação Fundamental. Parâmetros curriculares nacionais: geografia. Brasília: MEC/SEF, 1998.

BRAUDEL, F. Há uma Geografia do Indivíduo Biológico?. In: BRAUDEL, F. Escritos sobre história. São Paulo, Perspectiva, 1978.

BRUNHES, H. Geografia Humana. Rio de Janeiro, Editora Fundo de Cultura, 1962. 
CAMPOS, R. R. Breve histórico do pensamento geográfico brasileiro nos séculos XIXe $X X$. Jundiaí, Paco Editorial, 2011.

CAPEL, H. Geografía humana y ciencias sociales: una perspectiva histórica. Barcelona, Montesino, 1989.

Filosofia e ciência na geografia contemporânea: Uma introdução à geografia, volume 1. Maringa: Massoni, 2007.

Ruptura e continuidade no pensamento geográfico. Maringá, EDUEM, 2013.

CARLOS, A. F. A. A geografia brasileira, hoje: algumas reflexões. In: Terra Livre. São Paulo, ano 18, vol. 1, n. 18, jan-jun, 2002.

A "geografia crítica" e a crítica da geografia. In: COLOQUIO INTERNACIONAL DE GEOCRÍTICA, 9, 2007. Disponível em: $<$ http://www.ub.es/geocrit/9porto/anafani.htm>

A condição espacial. São Paulo, Contexto, 2011.

CARVALHO, M. B. de. O que é Natureza. São Paulo, Brasiliense, 1990.

. Da Antropogeografia do Final do Século XIX aos Desafios Transdiciplinares do Final do Século XX: O Debate Sobre as Abordagens Integradas da Natureza e da Cultura nas Ciências Sociais. Tese de doutorado, PUC/São Paulo, 1998.

A Natureza na Geografia do Ensino Médio. In: OLIVEIRA, A. U. (org.) Para onde vai o ensino de geografia? São Paulo, Contexto, 2005.

Geografia - ciência da complexidade (ou da reconciliação entre natureza e cultura). In: DANTAS, A. (org.) Geografia \& cultura, marxismo, complexidade, ensino, planejamento, saúde. Natal, EDUFRN, 2008.

CAVALCANTI, L. S. Geografia, escola e construção de conhecimentos. Campinas, Papirus, 2011.

CHASIN, J. A superação do liberalismo. Mimeo, s/d.

A sucessão na crise e a crise na esquerda. In: Ensaio, São Paulo, n. 17/18, 1989.

Marx - Da razão do mundo ao mundo sem razão. In: CHASIN, J. (org.) Marx hoje - volume um. São Paulo, Ensaio, 1990.

Marx no tempo da Nova Gazeta Renana. In: MARX, K. A burguesia e a contrarevolução. São Paulo, Ensaio, 1993.

Marx - A determinação ontonegativa da policitidade. Ensaios Ad Hominem. N. $\overline{1 \text {, Tomo } 3}$ - Política. São Paulo, Estudos e Edições Ad Hominem, 2000.

Ad Hominem - Rota e prospectiva para um projeto marxista. Ensaios Ad Hominem. N. 1, Tomo 4 - Marxismo, São Paulo, Estudos e Edições Ad Hominem, 2001. 2009. Marx - Estatuto ontológico e resolução metodológica. São Paulo, Boitempo,

CHASIN, M. O complexo categorial da objetividade nos escritos marxianos de 1843 a 1848. Dissertação de mestrado, UFMG, 1999.

A crítica da especulação nas glosas de Kreuznach. Ensaios Ad Hominem 1 Tomo IV: Dossiê Marx, Santo André, Estudos e Edições Ad Hominem, 2001. 
Política, limite e mediania em Aristóteles. Tese de doutorado em História Social, USP, 2007.

CHERVEL, A. História das disciplinas escolares: reflexões sobre um campo de pesquisa. Teoria \& Educação, 2, 177-229.

CHILDE, G. A evolução cultural do homem. Rio de Janeiro, Zahar, 3. ed., 1975.

CHRISTOFOLETTI, A. Perspectivas da Geografia. São Paulo, Difel, 1982.

COSGROVE, D. E. Em Direção a uma Geografia Cultura Radical: Problemas da Teoria. In: CORREAA, R. L.; ROSENDHAL, Z. Introdução à Geografia Cultural. Rio de Janeiro, Bertrand Brasil, 2011.

COSTA, M. H. M. A diferença entre as Categorias LEBENSÄUSSERUNG, ENTÄUSSERUNG, ENTFREMDUNG, VERÄUSSERUNG nos Manuscritos Econômicos e Filosóficos de Karl Marx de 1944. Dissertação de mestrado, UFMG, 1999.

A exteriorização da vida nos Manuscritos econômico-filosóficos de 1844. $\overline{\text { Ensaios A }}$ d Hominem 1 - Tomo IV: Dossiê Marx, Santo André, Estudos e Edições Ad Hominem, 2001.

COSTA, R. H. Filosofia, Geografia e Crise da Modernidade. In: Terra Livre 7 Geografia: Pesquisa e Prática Social. São Paulo, Editora Marco Zero, AGB, 1990.

O mito da desterritorialização: Do "fim dos territórios" à multiterritorialidade. Rio de Janeiro, Bertrand Brasil, 2004.

COTRIM, L. C. A. Marx - Política e emancipação humana: 1848-1871. Tese de doutorado, PUC-SP, 2007.

DAMIANI, A. L. População e geografia. São Paulo, Contexto, 2006.

DANTAS DA SILVA, A. A. "Monbeig, paisagem e geografia estigmática", Mercator, Revista de Geografia da UFC, ano 1, número 02, 2012.

"Monbeig e a noção de Complexo Geográfico", Confis, 7 (2009), disponível em http://confins.revues.org/6091; DOI : 10.4000/confins.6091, consultado em $14 / 10 / 2012$.

DARDEL, E. O homem e a Terra. São Paulo, Perspectiva, 2011.

DEMANGEON, A. Uma definição da geografia humana. In: CHRISTOFOLETTI, A. Perspectivas da Geografia. São Paulo, Difel, 1982.

DINIZ FILHO, L. L. Certa má herança marxista: elementos para repensar a geografia crítica. In: KOZEL, S.; MENDONÇA, F. A. (org.). Elementos de epistemologia da geografia contemporânea. Curitiba: Ed. da UFPR, 2002.

A geografia crítica brasileira: reflexões sobre um debate recente. Geografia, Rio Claro, v. 28, n. 3, p. 307-321, set.-dez. 2003

DOSSE, F. História do Estruturalismo: I. O campo do signo, 1945/1966. São Paulo, Ensaio, 1993.

História do Estruturalismo: II. O canto do cisne, de 1967 aos nossos dias. São Paulo, Ensaio, 1994.

DRESCH, J. Reflexões sobre a Geografia. In: Reflexões sobre a geografia, AGB, São Paulo, 1980. 
DUARTE, N. A rendição pós-moderna à individualidade alienada e a perspectiva marxista da individualidade livre e universal. In: DUARTE, N. (org.). Crítica ao fetichismo da individualidade, Campinas, Autores Associados, 2012.

$A$ individualidade para-si: contribuição a uma teoria histórico-social da formação do indivíduo. Campinas/São Paulo, Autores Associados, 2013.

DUMÉNIL, G.; LÖWY, M; RENAULT, E. Ler Marx. São Paulo, Editora Unesp, 2011.

DUNCAN, J. S. O Supraorgânico na Geografia Cultural Americana. In: CORREAA, R. L.; ROSENDHAL, Z. Introdução à Geografia Cultural. Rio de Janeiro, Bertrand Brasil, 2011.

EIDT, C. A razão como tribunal da crítica: Marx e a Gazeta Renana. Ensaios Ad Hominem 1 - Tomo IV: Dossiê Marx, Santo André, Estudos e Edições Ad Hominem, 2001.

ENDERLE, R. M. Ontologia e política: A formação do pensamento marxiano de 1842 a 1846. Dissertação de mestrado, Filosofia, UFMG, 2000.

ENGELS, F. A origem da família, da propriedade privada e do Estado. Rio de Janeiro, Civilização Brasileira, 1982.

Ludwig Feuerbach e o fim da filosofia clássica alemã. In: MARX, K.; ENGELS, F. Obras escolhidas. Tomo III. Lisboa, Edições progresso, 1985.

A situação da classe trabalhadora na Inglaterra. São Paulo, Boitempo, 2008.

ENGUITA, M. F. Trabalho, escola e ideologia: Marx e a crítica da educação. Porto Alegre, Artmed, 1993.

ESCOLAR, M. Crítica do discurso geográfico. São Paulo, Hucitec, 1996.

FERRARI, T. Fabricalização da cidade e ideologia da circulação. São Paulo, Outras Expressões, 2012.

FERRY, L. Homo aestheticus: A invenção do gosto na era democrática. São Paulo, Ensaio, 1994.

FEUERBACH, L. Princípios da filosofia do futuro. Lisboa, Edições 70, 1988.

A essência do cristianismo. Petrópolis, Vozes, 2009.

FORTES, R. V. As novas vias da ontologia em György Lukács: As bases ontológicas do conhecimento. Saarbrücken, Novas Edições Acadêmicas, 2013.

FOSTER, J. B. A ecologia de Marx: materialismo e natureza. Rio de Janeiro, Civilização Brasileira, 2005.

FRANÇA FILHO. A. L. Considerações sobre a renovação crítica da geografia brasileira. Geografia em questão, v. 05, n. 1, 2012.

FREDERICO, C. O jovem Marx: as origens da ontologia do ser social. São Paulo, Cortez, 1995.

Marx, Lukács: A arte na perspectiva ontológica. Natal, EDUFRN, 2005.

FROMM, E. Conceito marxista do homem. Rio de Janeiro, Zahar, 1983.

GABRIEL, M. Amor e Capital: A saga familiar de Karl Marx e a história de uma revolução. Rio de Janeiro, Zahar, 2013.

GEIGER, P. P. "Um olhar sobre a geografia no Brasil: Do Estado Novo à Nova República" 
As formas do espaço brasileiro. Rio de Janeiro, Zahar, 2003.

GEORGE, P. Sociologia e geografia. São Paulo, Forense, s/d.

GOMES, P. C. da C. Geografia e Modernidade. Rio de Janeiro, Bertrand Brasil, 2011.

GONÇALVES, C. W. P. A geografia está em crise. Viva a geografia. In: MOREIRA, R. (org.) Geografia: Teoria e Crítica: O saber posto em questão. Rio de Janeiro, Vozes, 1982.

Os (des)caminhos do meios ambiente. São Paulo, Contexto, 1996.

; AZEVEDO, N. M. de. A Geografia do Imperialismo: uma introdução. In: Boletim Paulista de Geografia, São Paulo, número 59, outubro de 1982.

HAESBAERT, R.; PEREIRA, S. N.; RIBEIRO, G. (orgs.). Vidal, vidais: textos de geografia humana, regional e política. Rio de Janeiro, Bertrand Brasil, 2012.

HARVEY, D. A justiça social e a cidade. São Paulo, Hucitec, 1980.

Condição pós-moderna. São Paulo, Edições Loyola, 2004

A produção capitalista do espaço. São Paulo, Annablume, 2005.

Espaços de esperança. São Paulo, Edições Loyola, 2006.

O enigma do capital. São Paulo, Boitempo, 2011.

Os limites do capital. São Paulo, Boitempo, 2013.

HELLER, A. Aristoteles y el mondo antiguo. Barcelona, Edicions 62, 1983.

HOBBES, T. Leviatã ou Matéria, forma e poder de um estado eclesiástico e civil. São Paulo, Abril Cultural (Os pensadores), 1983.

IANNI, O. Dialética \& Capitalismo: Ensaio sobre o pensamento de Marx. Petrópolis, Vozes, 1988.

KOFLER, L. História e dialética. Rio de Janeiro, Editora UFRJ, 2010.

KOSIC, K. Dialética do concreto. Rio de Janeiro, Paz e Terra, 1976.

LACOSTE, Y. A geografia. In: CHÂTELET, F. A filosofia das ciências sociais: De 1860 aos nossos dias. Rio de Janeiro, Zahar, 1974.

1985.

Geografia do subdesenvolvimento: geopolítica de uma crise. São Paulo, Difel,

Os países subdesenvolvidos. Rio de Janeiro, Bertrand Brasil, 1988.

"Braudel geógrafo" in LACOSTE, Y. (org.). Ler Braudel. Campinas, São Paulo, Papirus, 1989.

A geografia - isso serve, em primeiro lugar, para fazer a guerra. Campinas, São Paulo, Papirus, 13 ed., 2007.

LÁPINE, N. O jovem Marx. Lisboa, Editorial Caminho, 1983.

LEAL, F. M. Coordenadas geográficas: ser-no-mundo. Dissertação de mestrado, FFLCH-USP, Geografia Humana, 2010.

LEFEBVRE, H. O pensamento marxista e a cidade. Lisboa, Ulisseia, 1972.

A re-produção das relações de produção. Porto, Publicações Escorpião, 1973.

Para compreender o pensamento de Marx. Lisboa, Edições 70, 1975. 
A sociologia de Marx. Rio de Janeiro, Forense Universitária, 1979.

Lógica formal/Lógica dialética. Rio de Janeiro, Civilização Brasileira, 1991. A vida cotidiana no mundo moderno. São Paulo, Ática, 1991a. A revolução urbana. Belo Horizonte, Editora UFMG, 1999. O direito à cidade. São Paulo, Centauro, 2001. Marxismo. Porto Alegre, L\&PM, 2009.

LENIN, V. I. O Programa Agrário da Social-Democracia na Primeira Revolução Russa de 1905-1907. São Paulo, LECH, 1980.

LÖWY, M. As aventuras de Karl Marx contra o Barão de Münchhausen: marxismo e positivismo na sociologia do conhecimento. São Paulo, Cortez, 2003.

Política. In: DUMÉNIL, G.; LÖWY, M; RENAULT, E. Ler Marx. São Paulo, Editora Unesp, 2011.

LUKÁCS, G. Ensaios sobre literatura. Rio de Janeiro, Civilização Brasileira, 1968.

Ontologia do ser social: Princípios ontológicos fundamentais de Marx. São Paulo, Livraria Editora Ciências Humanas, 1979.

Determinações para a crítica particular do desenvolvimento da sociologia. In: LUKÁCS, G. Georg Lukács: sociologia (Coleção Grandes Cientistas Sociais). São Paulo, Ática, 1981.

As bases ontológicas do pensamento e da atividade do homem. In: O jovem Marx e outros escritos de filosofia. Rio de Janeiro, Editora UFRJ, 2007.

Prolegômenos para uma ontologia do ser social: questões de princípios para uma ontologia hoje tornada possível. Boitempo, São Paulo, 2010.

Para uma ontologia do ser social I. São Paulo, Boitempo, 2012.

Para uma ontologia do ser social II. São Paulo, Boitempo, 2013.

MANN, T. Confissões do impostor Felix Krull. Rio de Janeiro, Nova Fronteira, 2000.

MARTINS, E. R. Da geografia à ciência geográfica e o discurso lógico. Tese de doutorado, FFLCH-USP, Geografia Humana, 1996.

A geografia urbana na dissolução das identidades originárias. Scripta Nova -

Revista Electrónica de Geografía y Ciencias Sociales, disponível em: http://www.ub.edu/geocrit/sn-94-60.htm, 2001

Geografia e ontologia: o fundamento geográfico do ser. GEOUSP - Espaço e Tempo, São Paulo, No 21, pp. 33 - 51, 2007

Pensamento geográfico é geografia em pensamento. In: KATUTA, A. M; et al. (orgs.). Geografia e mídia impressa. Londrina, Moriá, 2009.

As dimensões do geográfico. Mimeo. 2013.

Geografia urbana e tempo geográfico. Mimeo, 2014.

MARTINS, L. L. Friedrich Ratzel através de um prisma. Dissertação de mestrado, UFRJ, 1993.

MARX, K. Para a crítica da economia política. São Paulo, Abril Cultural, 1982 (Os economistas). 
A miséria da filosofia. São Paulo, Global, 1985.

Formações econômicas pré-capitalistas. São Paulo, Paz e Terra, 1991.

Manuscritos econômico-filosóficos. São Paulo, Boitempo, 2004.

Crítica da filosofia do direito de Hegel. São Paulo, Boitempo, 2005

Crítica da filosofia do direito de Hegel - Introdução. In Crítica da filosofia do

direito de Hegel. São Paulo, Boitempo, 2005

Sobre a questão judaica. São Paulo, Boitempo, 2010.

Glosas críticas ao artigo " $O$ rei da Prússia e a reforma social'. De um prussiano". In MARX K.; ENGELS, F. Lutas de classes na Alemanha, São Paulo, Boitempo, 2010a.

Grundrisse. Manuscritos econômicos de 1857-1858. Esboços da crítica da economia política. São Paulo: Boitempo, 2011.

MARX, K.; ENGELS, F. Manifesto do partido comunista. São Paulo, Cortez, 1998.

A sagrada família. São Paulo, Boitempo, 2003.

A ideologia alemã. São Paulo, Boitempo, 2007.

MASCARO, A. L. Estado e forma política. São Paulo, Boitempo, 2013.

MELLO, A. F. Capitalismo e mundialização em Marx. São Paulo, Perspectiva, 2000.

MERCIER, G. A região e o estado segundo Friedrich Ratzel e Paul Vidal de la Blache. GEOgraphia - Edição espacial de artigos internacionais, Niterói, UFF, EGG, 2012.

MÉSZÁROS, I. A necessidade do controle social. São Paulo, Ensaio, 1987.

Filosofia, ideologia e ciência social: Ensaios de negação e afirmação. São Paulo, Ensaio, 1993.

Para além do capital. São Paulo, Boitempo, 2002.

Teoria da alienação em Marx. São Paulo, Boitempo, 2006.

Estrutura social e formas de consciência: a determinação social do método. São Paulo, Boitempo, 2009.

MORAES, A. C. R. A antropogeografia de Ratzel: Indicações. In: RAZTEL, F. Ratzel. São Paulo, Ática (Grandes Cientistas Sociais), 1990.

Hucitec, 1996.

Ideologias geográficas: espaço, cultura e política no Brasil. São Paulo,

Geografia, capitalismo e meio ambiente. Tese de livre docência, FFLCH-USP, 2000.

A gênese da geografia moderna. São Paulo, Hucitec, Annablume, 2002.

Geografia: pequena história crítica. São Paulo, Hucitec, 12 ed., 2002.

Território e história no Brasil. São Paulo, Annablume, 2005.

"Na trilha do purgatório: política e modernidade na geografia brasileira contemporânea". In SILVA, J. B.; LIMA, L. C.; DANTAS, E. W. (orgs.). Panorama da geografia brasileira II. São Paulo, Annablume, 2006. 
Hucitec, 1999.

COSTA, W. M. Geografia crítica: A valorização do espaço. São Paulo,

MOREIRA, R. O que é Geografia (Coleção Primeiros Passos). São Paulo, Brasiliense, 1983.

O discurso do avesso (Para a Crítica da Geografia que se Ensina). Rio de Janeiro, Dois Pontos, 1988.

Assim se passaram dez anos (A Renovação da Geografia no Brasil no Período 1978-1988). GEOgraphia, Rio de Janeiro, ano II, n. 3, 2000.

Marxismo e geografia (A geograficidade e o diálogo das ontologias).

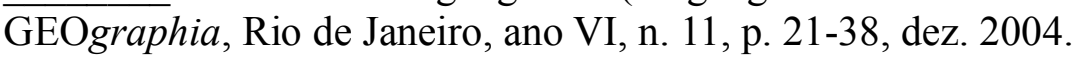

Para onde vai o pensamento geográfico? Por uma epistemologia crítica. São Paulo, Contexto, 2006.

O pensamento geográfico brasileiro - Volume Um: as matrizes clássicas originárias. São Paulo, Contexto, 2008.

Pensar e ser em geografia. São Paulo, Contexto, 2010.

NETTO, J. P. Capitalismo e reificação. São Paulo, Livraria e Editora Ciências Humanas, 1981.

A propósito da Crítica de 1843 in Revista Nova Escrita Ensaio: Marx hoje. São Paulo, ano V, n. 11/12, 1983.

XV, abr., 1994.

Razão, ontologia e práxis. Serviço social \& sociedade. São Paulo, Cortez, Ano

Lukács e o marxismo ocidental. In: ANTUNES, R.; RÊGO, W. D. L. Lukács: Um Galileu no Século XX. São Paulo, Boitempo, 1996.

Crise do socialismo e ofensiva neoliberal. São Paulo, Cortez, 2001.

Cortez, 2004.

Ditadura e Serviço Social: Uma análise do Serviço Social pós-64. São Paulo,

Uma face contemporânea da barbárie. Comunicação. III Encontro Internacional Civilização ou Barbárie, Serpa, 2010.

Introdução ao estudo do método de Marx. São Paulo, Expressão Popular, 2011.

\section{8.}

; BRAZ, M. Economia política: Uma introdução crítica. São Paulo, Cortez,

PEDROSA, B. V. Entre as ruínas do muro: a história da geografia crítica sob a ótica da estrutura. Tese (Doutorado em Geografia Humana), USP, São Paulo, 2013.

"A controvérsia da geografia crítica no Brasil”. No prelo, 2014.

PEET, R. O desenvolvimento da geografia radical nos Estados Unidos. In: CHRISTOFOlETTI, A. Perspectivas da Geografia. São Paulo, Difel, 1982.

PEREIRA, D. A AGB, os movimentos sociais e a geografia: UPEGE, AGB e movimento estudantil no final da década de 70. In: Boletim Paulista de Geografia, São Paulo, Seção São Paulo - Associação dos Geógrafos Brasileiros, n. 88, jul. 2008.

PEREIRA, J. V. C. A propósito da Evolução, Conceito e Método da Geografia. Boletim Geográfico, IBGE, 1945, v. 2, n. 22. 
QUAINI, M. Marxismo e geografia. Rio de Janeiro, Paz e Terra, 1979. . A construção da geografia humana. Rio de Janeiro, Paz e Terra, 1992.

RAFFESTIN, C. Por uma geografia do poder. São Paulo, Ática, 1993.

RANIERI, J. Apresentação: Sobre os chamados Manuscritos econômico-filosóficos de Karl Marx. In MARX, K. Manuscritos econômico-filosóficos. São Paulo, Boitempo, 2004.

RATZEL, F. Ratzel - Coleção Grandes Cientistas Sociais. São Paulo, Ática, 1990.

RIBEIRO, G. Para ler geografia ou a geografia segundo Febvre. Terra livre, São Paulo, AGB, ano 25, vol. 1, n. 32, jan-jun, 2009.

ROBIC, M. C.; OZOUF-MARIGNIER, M. A França no limiar dos novos tempos : Paul Vidal de La Blache e a regionalização. GEOgraphia - Edição espacial de artigos internacionais, Niterói, UFF, EGG, 2012.

ROCHA, F. A. O complexo categorial da subjetividade nos escritos marxianos de 1843 a 1848. Dissertação de mestrado, UFMG, 2003.

ROCHA, G. O. R. A trajetória da disciplina geografia no currículo escolar brasileiro (1837-1942). Dissertação de mestrado, PUC-SP, 1996.

RUBEL, M. Crônica de Marx. São Paulo, Ensaio, 1991.

SANTOS, D. A reinvenção do espaço: Diálogos em torno da construção do significado de uma categoria. São Paulo, Unesp, 2002.

Referencial curricular. Fundação Bradesco, Versão Preliminar, mimeo, 2004.

Entrevistas: Douglas Santos. In: Boletim Paulista de Geografia, São Paulo, Seção São Paulo - Associação dos Geógrafos Brasileiros, n. 88, jul. 2008.

SANTOS, M. Por uma geografia nova. São Paulo, Hucitec, 1980.

O espaço do cidadão. São Paulo, Edusp, 2002.

Testamento intelectual. São Paulo, Editora UNESP, 2004.

Da totalidade ao lugar. São Paulo, Edusp, 2005.

Pensando o espaço do homem. São Paulo, Edusp, 2007.

2008.

A natureza do espaço: Técnica e tempo. Razão e emoção. São Paulo, Edusp,

Metamorfoses do espaço habitado. São Paulo, Edusp, 2008.

Espaço e método. São Paulo, Edusp, 2008.

Espaço, Mundo Globalização, Modernidade. In: SANTOS, M. Técnica, Espaço, Tempo: Globalização e Meio Técnico-científico-informacional. São Paulo, EDUSP, 2008b.

SARTELLI, E. El difícil arte de la liberación humana: Marx-Bauer: acerca de la verdadeira naturaleza de un debate crucial. In: MARX, K. Sobre la liberación humana. Buenos Aires, RyR, 2012.

SARTÓRIO, L. A. V. A antropologia de Feuerbach e alguns delineamentos acerca de uma possível influência no pensamento de Marx. 2001. Dissertação de Mestrado (Filosofia). PUC, São Paulo. 
SAVIANI, D. Escola e democracia: teorias da educação, curvatura da vara, onze teses sobre a educação política. Campinas, Autores Associados, 2007.

. Pedagogia histórico-crítica: Primeiras aproximações. Campinas, São Paulo, Autores Associados, 2008.

Perspectiva marxiana do problema subjetividade-intersubjetividade. In: DUARTE, N. (org.). Crítica ao fetichismo da individualidade. Campinas, Autores Associados, 2012.

. Marxismo, educação e pedagogia. In: SAVIANI, D.; DUARTE, N. Pedagogia histórico-crítica e luta de classes na educação escolar. Campinas, Autores Associados, 2012.

; DUARTE, N. A formação humana nas perspectiva histórico-ontológica. In: SAVIANI, D.; DUARTE, N. Pedagogia histórico-crítica e luta de classes na educação escolar. Campinas, Autores Associados, 2012.

SCHAFF, A. O marxismo e o indivíduo. Rio de Janeiro, Civilização Brasileira, 1967.

SEVE, L. A personalidade em gestação. In: SILVEIRA, P; DORAY, B. (orgs.). Elementos para uma teoria marxista da subjetividade. São Paulo, Vértice, 1989.

SENNET, R. Carne e pedra: o corpo e a cidade na civilização ocidental. Rio de Janeiro, Best Bolso, 2008.

SILVA, A. C. da. O espaço fora do lugar. São Paulo, Hucitec, 1978.

A renovação geográfica no Brasil: 1976-1983. As geografias radical e crítica na perspectiva teórica. Boletim Paulista de geografia. São Paulo, AGB-São Paulo, n. 60, 1983.

As categorias como fundamentos do conhecimento geográfico. In: SANTOS, M.; SOUZA, M. A. A. (coords.). O espaço interdisciplinar. São Paulo, Nobel, 1986.

SILVA, J. L. B. da. Notas introdutórias de um itinerário interpretativo sobre a formação do pensamento geográfico brasileiro. Dissertação (Mestrado em Geografia Humana) USP, São Paulo, 1996.

O que está acontecendo com o ensino da geografia? - Primeiras impressões in PONTUSCHKA, N. N.; OLIVEIRA, A. U. (orgs.) Geografia em perpectiva: ensino e pesquisa. São Paulo: Contexto, 2012.

SILVA, S. M. A fenomenologia do egoísmo: Stirner e a crítica marxiana. Ensaios Ad Hominem 1 - Tomo IV: Dossiê Marx, Santo André, Estudos e Edições Ad Hominem, 2001.

SILVEIRA, P. Da alienação ao fetichismo - formas de subjetivação e de objetivação. In: SILVEIRA, P; DORAY, B. (orgs.). Elementos para uma teoria marxista da subjetividade. São Paulo, Vértice, 1989.

SILVEIRA, R. W. D. da.; VITTE A. C. Natureza em Alexander von Humboldt: entre a ontologia e o empirismo. Mercator, vol. 9, número 20, set./dez. 2010.

A emergência de um novo saber geográfico: o retorno da ciência à filosofia. In: Sociedade \& Natureza, Uberlândia, 23 (1), abr. 2011.

SMITH, N. Desenvolvimento desigual. Rio de Janeiro, Bertrand Brasil, 1988.

SODRÉ, N. Introdução à Geografia (Geografia e Ideologia). Petrópolis, Vozes, 1976. 
SOJA, E. Geografias pós-modernas: A reafirmação do espaço na teoria social crítica. Rio de Janeiro, Zahar, 1993.

SORRE, M. El hombre en la tierra. Barcelona, Editorial Labor, 1967.

Sorre-Coleção Grandes Cientistas Sociais. São Paulo, Ática, 1987.

SOUZA, M. L. "Espaciologia": uma objeção (crítica aos prestigiamentos pseudo-críticos do espaço social). Terra Livre. São Paulo, Marco Zero/AGB, n. 5, 1988.

O pensamento crítico e a análise socioespacial - lugar e atualidade de Marx e dos marxismos (apontamentos para um 'acerto de contas' construtivo). In: DANTAS, A. (org.) Geografia \& cultura, marxismo, complexidade, ensino, planejamento, saúde. Natal, EDUFRN, 2008.

TATHAM, G. A Geografia no Século XIX. Boletim Geográfico. Rio de Janeiro, n. 150, ano XVII, 1959.

TEIXEIRA, P. T. F. A individualidade humana na obra marxiana de 1843 a 1848. Ensaios Ad Hominem 1, Tomo I - Marxismo, São Paulo, Estudos e Edições Ad Hominem, 1999.

TONET, I. Método científico: uma abordagem ontológica. São Paulo, Instituto Lukács, 2013.

VAISMAN, E. A determinação marxiana da ideologia. Tese doutoral, UFMG, 1996.

Dossiê Marx: itinerário de um grupo de pesquisa. Ensaios Ad Hominem. Tomo 4: Dossiê Marx. São Paulo, Estudos e Edicções Ad Hominem, 2001.

Marx e Lukács e o problema da individualidade: algumas aproximações. Perspectiva, Florianópolis, v. 27, n. 2, jul./dez., 2009.

VALVERDE, O. Evolução da geografia brasileira no após-guerra. Mimeo, s/d.

VASCONCELOS, V. V.;HADAD, R. M.; MARTINS Júnior, P. P. "Pierre Monbeig: Da escola regionalista francesa às frentes agropecuárias brasileiras", Atêlie Geográfico, Goiânia, v. 6, n. 4, dez. 2012.

VÁZQUEZ, A. S. Filosofia da práxis. Rio de Janeiro, Paz e Terra, 1977.

VESENTINI, J. W. Percalços da Geografia crítica: entre a crise do marxismo e o mito do conhecimento científico. Anais do $4^{\circ}$ Congresso Nacional de Geógrafos, v. 2, São Paulo, AGB, 1984.

Geografia crítica no Brasil: uma interpretação depoente. In: VESENTINI, J. W. Ensaios de geografia crítica: história, epistemologia e (geo)política. São Paulo, Plêiade, 2009.

VIDAL DE LA BLACHE, P. A geografia na escola primária. Boletim do Conselho Nacional de Geografia, ano I, n. 1, abril de 1943.

Princípios de geografia humana. Lisboa, Cosmos, 1959.

As características próprias da geografia. In: CHRISTOFOLETTI, A. Perspectivas da Geografia. São Paulo, Difel, 1982.

Quadros da Geografia da França. GEOgraphia, ano 1, n. 1, 1999.

A Geografia Política. A propósito dos escritos de Friedrich Ratzel. GEOgraphia, n. 7, vol. IV, 2002. 
I. Geografia Geral. Os Gêneros de Vida na Geografia Humana. GEOgraphia, ano 7, n. 13, 2005.

VIEIRA, C. A. C. Antigo regime e transição: breve estudo em torno do capital mercantil e do absolutismo. Tese de doutorado, IE-Unicamp, História Econômica, 2012.

VITTE, A. C. Da Metafísica da Natureza à Gênese da Geografia Física Moderna. Geographia, ano VIII, n. 15, 2006.

ZANATTA, B. Geografia escolar brasileira: avaliação crítica das atuais orientações metodológicas para conteúdos e métodos de ensino da Geografia. Tese (Doutorado em Educação Brasileira). Unesp, Marília, 2003. 